MIPLC Studies

Eva Riemann

\title{
Contextual Brand Valuation
}

From Fundamental Issues and Analysis of the State of the Art to a Systematic Integrated Approach to Brand and Intellectual Property (E)Valuation 


Universität
University




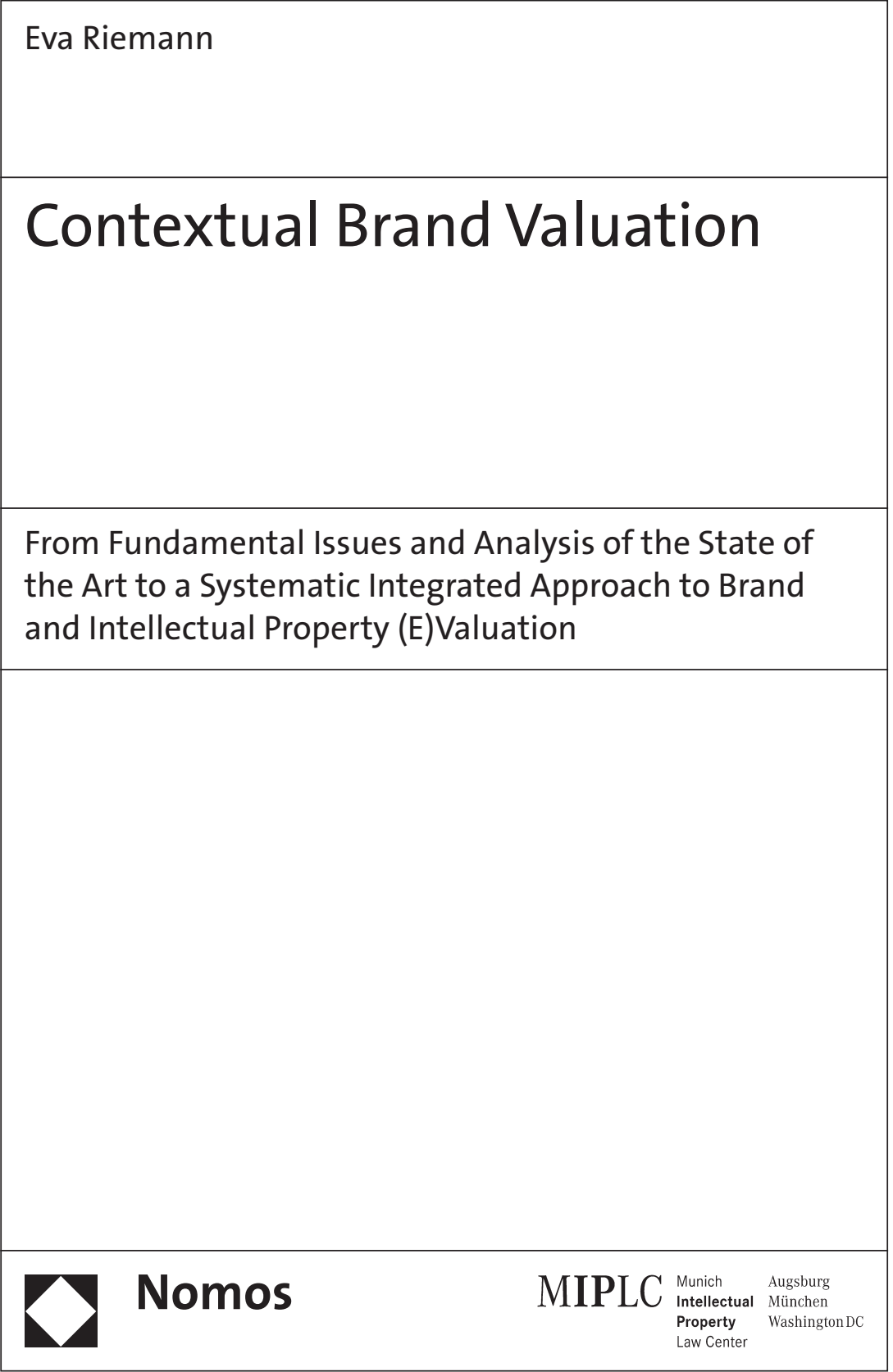


Die Deutsche Nationalbibliothek verzeichnet diese Publikation in der Deutschen Nationalbibliografie; detaillierte bibliografische Daten sind im Internet über http://dnb.d-nb.de abrufbar.

The Deutsche Nationalbibliothek lists this publication in the Deutsche Nationalbibliografie; detailed bibliographic data is available in the Internet at http://dnb.d-nb.de .

a.t.: Munich, Univ., Diss., 2011

ISBN 978-3-8329-7637-8

1. Auflage 2012

(c) Nomos Verlagsgesellschaft, Baden-Baden 2012. Printed in Germany. Alle Rechte, auch die des Nachdrucks von Auszügen, der fotomechanischen Wiedergabe und der Übersetzung, vorbehalten. Gedruckt auf alterungsbeständigem Papier.

This work is subject to copyright. All rights are reserved, whether the whole or part of the material is concerned, specifically those of translation, reprinting, re-use of illustrations, broadcasting, reproduction by photocopying machine or similar means, and storage in data banks. Under $\S 54$ of the German Copyright Law where copies are made for other than private use a fee is payable to "Verwertungsgesellschaft Wort", Munich. 
For Mäm. 



\section{Acknowledgements}

Everyone without whom this work would not exist deserves my sincerest thanks: First and foremost Prof. Dr. Dres. h.c. Joseph Straus. He took on this very diverse topic, accompanied me with it and gave valuable advice while letting me enjoy a considerable degree of scientific freedom.

Cordial thanks also to Prof. Dr. Annette Kur for her time and input regarding the trade mark law part and to Prof. Dr. Michael Lehmann for acting as second reader.

Many thanks to the Max Planck Society, the Max Planck Institute for Intellectual Property, Competition and Tax Law (now Max Planck Institute for Intellectual Property and Competition Law) and the Munich Intellectual Property Law Center (MIPLC) for providing me with the luxury of a stipend and thereafter taking me on as a scientific associate. During this time I wrote most of this work. I would like to express my gratitude to Prof. Martin J. Adelman, Prof. Robert Brauneis, Prof. Kenneth D. Crews and The Honorable Randall R. Rader, Chief Judge (in alphabetical order) for supporting the MIPLC (where I took my first steps in the IP world), both financially and/or humanly, in their unique and unobtrusive ways.

My family, most notably my mother and brother, have always given me matchless tangible and intangible support. So have my close friends. I am very happy and thankful about these invaluable assets. In particluar, the two most important men in my life, my husband Robert and our son Rasmus, deserve all my gratitude for their love, belief in me, support and for reminding me, time and again, to follow my heart. 



\section{Contents}

Acknowledgements $\quad 5$

$\begin{array}{ll}\text { Contents } & 7\end{array}$

$\begin{array}{ll}\text { List of Figures } & 15\end{array}$

$\begin{array}{ll}\text { Table of Abbreviations } & 17\end{array}$

1 Introduction $\quad 21$

1.1 Objectives and Structure of this Thesis . . . . . . . . . . 23

1.1.1 Objectives . . . . . . . . . . . . . 23

1.1.1.1 Structured Examination of Fundamental Valuation Issues . . . . . . . . . . . . . . 23

1.1.1.2 Improvement of Tradability of IP as Assets: Reduction of Information Asymmetries and of Risks . . . . . . . . . . . . . . . 23

1.1.1.3 Value Implications of Trade Mark Law . . . . 24

1.1.1.4 Valuation and Evaluation . . . . . . . . 25

1.1.2 Structure . . . . . . . . . . . . . . . 25

1.1.2.1 Provision of Essential Knowledge . . . . . . . 26

1.1.2.2 Definition of the Desired Stage . . . . . . . 26

1.1.2.3 Examination of the Current Stage . . . . . . 26

1.1.2.4 Introduction of Means to Overcome this Gap 27

1.2 Distinguishing Reporting from Forecasting Valuations . . . . . 27

1.3 General Framework Underlying the Value of any Asset . . . . 29

1.3.1 Scarcity . . . . . . . . . . . . . . . . . 29

1.3.2 Utility and Title . . . . . . . . . . . . . 30

1.3.3 Intermediate Findings . . . . . . . . . . . . . . 31

1.4 Requirements a Forecasting Valuation Technique Must Meet . 31 
1.4.1 Conceptual and Methodical Soundness . . . . . . . . 32

1.4.1.1 Comprehensiveness . . . . . . . . . . . . . . . . . . . . . 32

1.4.1.2 Context ................ . . 33

1.4.1.3 Transparency . . . . . . . . . . . . . 33

1.4.1.4 Flexibility . . . . . . . . . . . . 34

1.4.1.5 Reduction of Asymmetries of Information and Reduction of Risks . . . . . . . . 35

1.4.1.6 Reliability vs. Accuracy . . . . . . . . . . 36

1.4.1.7 An Appropriate Degree of Objectivity . . . . 37

1.4 .2 Widespread Acceptance . . . . . . . . . . . . . 38

1.4.3 Manageable Output . . . . . . . . . . . . . . . . 39

1.4.3.1 Future Orientation . . . . . . . . . . . . . 39

1.4.3.2 Comparability of Results . . . . . . . . . . 40

1.4 .4 Findings . . . . . . . . . . . . . . . . 40

1.5 Summary . . . . . . . . . . . . . . . 41

2 Brand Valuation Fundamentals $\quad 43$

2.1 Nature of Trade Marks and Brands . . . . . . . . . . . . . . 43

2.1.1 Intangible Assets and Intellectual Property . . . . . . . 43

2.1.1.1 Intangible Assets . . . . . . . . . . . . . . 43

2.1.1.2 IP vs. Intangible Assets . . . . . . . . . . . . . 46

2.1.1.3 Value Drivers and Detractors . . . . . . . . 46

2.1.1.3.1 Network Effects . . . . . . . . . . 47

2.1.1.3.2 Nonrivalry . . . . . . . . . . . . 49

2.1.1.3.3 Scalability . . . . . . . . . . 50

2.1.1.3.4 Nontradability . . . . . . . . . . 51

2.1.1.3.5 Partial Excludability and Spillovers . 53

2.1.1.3.6 Inherent Risk . . . . . . . . . . . . . . . . . 53

2.1.1.3.7 Legal Scarcity . . . . . . . . . . . . . . . . . 55

2.1.1.4 Intermediate Findings . . . . . . . . . . 56

2.1.2 The Term 'Trade Mark' as Opposed to 'Brand' . . . . 56

2.1.2.1 Trade Marks - Definition and Functions . . . 57

2.1.2.1.1 Trade Marks as Legal Phenomena . . 57

2.1.2.1.2 Trade Mark Types . . . . . . . . . . 59

2.1.2.1.3 Trade Mark Functions . . . . . . . . 60

2.1.2.2 Brands - Definition and Functions . . . . . . 63

2.1.2.2.1 Brands as Personality-like Phenomena 64 
2.1.2.2.2 Brand Types . . . . . . . . . . . . . 72

2.1.2.2.3 Brand Functions . . . . . . . . . 73

2.1.2.3 Intermediate Findings . . . . . . . . . . 76

2.1 .3 Findings . . . . . . . . . . . . . . . . . . . . . . . . 77

2.2 Introduction to Brand Valuation . . . . . . . . . . . 77

2.2.1 Development of Brand Valuation . . . . . . . . 77

2.2.2 Definition and Origins of Brand Value . . . . . . . . 80

2.2.2.1 Brand Value Defined . . . . . . . . . . . 80

2.2.2.2 Sources of Brand Value . . . . . . . . . . . . . . . . . . 83

2.2 .3 Findings . . . . . . . . . . . . . . . . . 84

2.3 Reasons for Brand Valuation . . . . . . . . . . . . . 85

2.3.1 Strategic and Operative Brand Management and

Brand Controlling . . . . . . . . . . . . . 86

2.3.1.1 Marketing - Planning, Implementation and Control . . . . . . . . . . . . . . . 89

2.3.1.2 Communication with the Financial, Investment and Press Communities . . . . . . . . . 91

2.3.1.3 Assessment of Employee Bonuses . . . . . . . 91

2.3.2 Brand Transactions . . . . . . . . . . . . . . . . . 91

2.3.2.1 Brand Transfer (M\&A, Outright Sale) . . . . 91

2.3.2.2 Licencing . . . . . . . . . . . . . . . . . . 94

2.3.2.3 Bankruptcy . . . . . . . . . . . . . . . . . . . 96

2.3 .3 Brand Finance . . . . . . . . . . . . . . . . . . . . 96

2.3.3.1 Collateralisation for Financial Needs . . . . . 97

2.3.3.2 Credit Rating . . . . . . . . . . . . . . . 97

2.3.3.3 Securitisation . . . . . . . . . . . . . . . 98

2.3.4 Brand Protection . . . . . . . . . . . . . . . 99

2.3.4.1 Brand Protection Strategy . . . . . . . . . . 99

2.3.4.2 Assessment of Damages and Amount in Dispute100

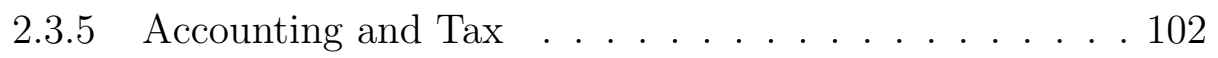

2.3.5.1 Accounting . . . . . . . . . . . . . 102

2.3.5.1.1 International . . . . . . . . . 103

2.3.5.1.2 European Community . . . . . . 106

2.3.5.1.3 Germany .......... . . 106

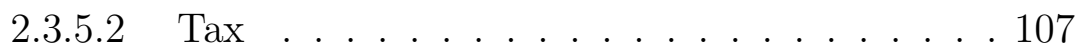

2.3.5.2.1 Transfer Pricing. . . . . . . . . . 107

2.3.5.2.2 Corporate Succession . . . . . . . . 109 
2.3 .6 Findings . . . . . . . . . . . . . . . . 110

2.4 Summary and Conclusions . . . . . . . . . . . . . . 110

3 Brand Valuation - State of the Art 113

3.1 The Current Brand Valuation Landscape . . . . . . . . . . . 113

3.1 .1 General Issues and Trends . . . . . . . . . . . . . . 113

3.1.2 Systematisation of Brand Valuation Methods . . . . . . 116

3.1.3 Empirical Data on Distribution Rates: Surveys . . . . . 118

3.1.3.1 Drees (1999) . . . . . . . . . . . . . 119

3.1.3.2 Günther and Kriegbaum-Kling (1999) . . . . 120

3.1.3.3 Schimansky et al. (2003) . . . . . . . . . . . . 121

3.1.3.4 Völckner and Pirchegger (2004) . . . . . . . . 122

3.1.3.5 Intermediate Findings . . . . . . . . . . . 123

3.1.4 Findings . . . . . . . . . . . . . . . . 126

3.2 Analysis of Currently Applied Brand Valuation Methods . . . 127

3.2 .1 Introduction . . . . . . . . . . . . . . 127

3.2.1.1 Selection Criteria . . . . . . . . . . . . 127

3.2.1.1.1 Practical Significance . . . . . . . 128

3.2.1.1.2 Sufficient Elaboration . . . . . . 128

3.2.1.2 Assessment Criteria . . . . . . . . . . . . 128

3.2 .2 Financial Techniques . . . . . . . . . . . . . . . 129

3.2.2.1 The General Approaches . . . . . . . . . . . . 129

3.2.2.1.1 Cost Approach . . . . . . . . . 130

3.2.2.1.2 Market Approach . . . . . . . . . . 132

3.2.2.1.3 Income Approach, Discounted Cash

Flow and Decision Tree Analysis . . 134

3.2.2.2 Derivative Generic and Proprietary Methods . 141

3.2.2.2.1 Price Premium . . . . . . . . . . . 142

3.2.2.2.2 Licence Analogy / Relief from Royalty 145

3.2.2.2.3 WoReWert $\AA$ by Repenn . . . . . . . 147

3.2.2.3 Intermediate Findings . . . . . . . . . . . . 149

3.2 .3 Psychographic Models . . . . . . . . . . . . . . . 150

3.2.3.1 Examination of Indicators . . . . . . . . . . 152

3.2.3.2 Brand Iceberg Model by Icon Added Value . . 153

3.2.3.3 Intermediate Findings . . . . . . . . . . 156

3.2.4 Financial-Behavioural (Hybrid) Models . . . . . . . . 157

3.2.4.1 Brand Performance System by ACNielsen . . 158 
3.2.4.2 Interbrand Brand Valuation . . . . . . . . . 163

3.2.4.3 Intermediate Findings . . . . . . . . . . . 168

3.2 .5 Conclusions . . . . . . . . . . . . . . . . . . . . 169

3.3 Summary and Outlook . . . . . . . . . . . . . . 170

3.3.1 Important Brand Valuation Developments and Issues . 170

3.3.2 First Steps Towards a Possible Solution . . . . . . . . . 172

4 A Systematic Integrated Valuation Methodology 175

4.1 Overview of the Valuation Process . . . . . . . . . . . . . . 175

4.1.1 Financial Income-Based Analysis . . . . . . . . . . 176

4.1.1.1 Income Approach, DCF and Decision Tree Analysis . . . . . . . . . . . 176

4.1.1.2 Assessing the Spread . . . . . . . . . . . . . . . . . . . . . . .

4.1.1.2.1 One-Party Scenarios . . . . . . . . 178

4.1.1.2.2 Two- or Multi-Party Scenarios . . . . 178

4.1.1.3 Intermediate Findings . . . . . . . . . . . 180

4.1 .2 Prismatic Evaluation . . . . . . . . . . . . . . 180

4.1.2.1 Compilation of the Four Dimensions of Value 182

4.1.2.2 Assessment of the Dimensions: Comparative Evaluation . . . . . . . . . 186

4.1.2.2.1 Point Score System . . . . . . . . 187

4.1.2.2.2 Combination with the Value Spread 188

4.1.2.3 Intermediate Findings . . . . . . . . . . . . 191

4.1 .3 Conclusions . . . . . . . . . . . . . . . . . . . . . . . 191

4.2 Satisfaction of Mandatory Requirements . . . . . . . . . . 192

4.2.1 Conceptual and Methodical Soundness . . . . . . . . . 192

4.2.1.1 Comprehensiveness . . . . . . . . . . . . . 193

4.2.1.2 Context . . . . . . . . . . . . . . . . 193

4.2.1.3 Transparency . . . . . . . . . . . . . . . . . . . . . . . . . . . . . . . . . . .

4.2.1.4 Flexibility . . . . . . . . . . . . . . . . 194

4.2.1.5 Reduction of Asymmetry of Information and of Risk . . . . . . . . . . . . . . . . 194

4.2.1.6 Reliability . . . . . . . . . . . . . 195

4.2.1.7 An Appropriate Degree of Objectivity . . . . 196

4.2.2 Widespread Acceptance . . . . . . . . . . . . . . 197

4.2 .3 Manageable Output . . . . . . . . . . . . . . . 197

4.2.3.1 Future Orientation . . . . . . . . . . . 197 
4.2.3.2 Comparability of Results . . . . . . . . . . 198

4.2 .4 Findings . . . . . . . . . . . . . . . . . . . 198

4.3 Summary . . . . . . . . . . . . . . . . . . . . . 199

5 The Legal Dimension $\quad 201$

5.1 Introduction . . . . . . . . . . . . . . . . . 201

5.2 Qualitative Scope of Protection . . . . . . . . . . . . . 206

5.2 .1 Introductory Remarks . . . . . . . . . . . . . . 206

$5.2 .2 \quad$ Abstract Distinctiveness . . . . . . . . . . . . . . . . . . . . . . . . . . . . .

5.2.2.1 The Law in General . . . . . . . . . . . 207

$5.2 .2 .2 \quad$ Value Implications . . . . . . . . . . . 208

5.2 .3 Concrete Distinctiveness . . . . . . . . . . . . . 208

5.2.3.1 The Law in General . . . . . . . . . . . 208

5.2.3.2 Three-dimensional Marks . . . . . . . . . . 212

5.2.3.3 Colours and Colour Combinations . . . . . . 214

5.2.3.4 Vowel-free Marks . . . . . . . . . . . . . . 215

5.2.3.5 Value Implications . . . . . . . . . . . . . . . . . . . . . . . . . . . . . . . .

5.2 .4 Non-Descriptiveness . . . . . . . . . . . . . . . 217

5.2.4.1 The Law in General . . . . . . . . . . . . 217

5.2.4.2 Value Implications . . . . . . . . . . . . . 219

5.2 .5 Graphical Representability . . . . . . . . . . . . . . . . . . . . . . . . . . . . .

5.2.5.1 The Law in General . . . . . . . . . . . . 219

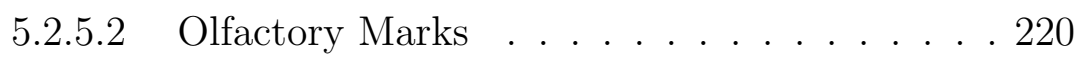

5.2.5.3 Audio Marks . . . . . . . . . . . . . . . . . . . . . . . . . . . . . . . . 221

5.2.5.4 Abstract Colour Marks . . . . . . . . . . . . 222

5.2.5.5 Value Implications . . . . . . . . . . . . . 223

5.2.6 Findings - Relation to Brand Value . . . . . . . . . . 223

5.3 Quantitative Scope of Protection - the Classes . . . . . . . . . 224

5.3.1 System of Trade Mark Classification . . . . . . . . . 224

5.3.2 Findings - Relation to Brand Value . . . . . . . . . . . 225

5.4 Geographic Scope of Protection . . . . . . . . . . . . . . . . . . . . . . . . . . . . .

5.4 The Law . . . . . . . . . . . . . . . . 226

5.4 .2 Findings - Relation to Brand Value . . . . . . . . . . . 227

5.5 Temporal Scope of Protection . . . . . . . . . . . . . 228

5.5.1 Beginning and Duration of Protection . . . . . . . . . 228

5.5.2 Findings - Relation to Brand Value . . . . . . . . . . 228

5.6 Origin of Trade Mark Protection: Registered Trade Marks . 229 
5.6.2 International, European and National Registration Systems

5.6.2.1 National Registration - Example Germany . . 230

5.6.2.2 The Madrid System . . . . . . . . . . . . 232

5.6.2.2.1 International Registration Procedure 233

5.6.2.2.2 The Madrid Protocol . . . . . . . . . 234

5.6.2.3 Community Trade Mark Registration . . . . . 237

5.6 .3 Relation to Brand Value . . . . . . . . . . . . . . . . 239

5.7 Origin of Trade Mark Protection . . . . . . . . . . . . . 240

5.7 .1 Introductory Remarks . . . . . . . . . . . . . 240

5.7 .2 Well-Known Marks . . . . . . . . . . . . . . . . . . . . 241

5.7.3 Trade Marks Acquired Through Use . . . . . . . . . . 243

5.7 .4 Relation to Brand Value . . . . . . . . . . . . . . . . . 244

5.8 Use . . . . . . . . . . . . . . . . . . . . . . . . . . . . 245

5.8 .1 The Law in General . . . . . . . . . . . . . 245

5.8.2 Findings - Relation to Brand Value . . . . . . . . . . . 245

5.9 Title . . . . . . . . . . . . . . . . . 246

5.9 .1 Introductory Remarks . . . . . . . . . . . . . . . . . . . . . . . . . .

5.9 .2 Relation to Brand Value . . . . . . . . . . . . . . 246

5.10 Prosecution, Litigation and Settlement . . . . . . . . . . 247

5.10 .1 Introductory Remarks _. . . . . . . . . . . . 247

5.10 .2 Relation to Brand Value . . . . . . . . . . . . . . 247

5.11 Likelihood of Confusion . . . . . . . . . . . . . . 248

5.11 .1 The Law in General . . . . . . . . . . . . . . 248

5.11 .2 Findings - Relation to Brand Value . . . . . . . . . . 250

5.12 Protection Beyond Similarity . . . . . . . . . . . . 251

5.12 .1 Introduction . . . . . . . . . . . . . . . . 251

5.12 .2 Trade Marks With a Reputation . . . . . . . . . . . . 251

5.12 .3 Well-Known Marks . . . . . . . . . . . . . . . . . . 254

5.12 .4 Implications on Brand Value . . . . . . . . . . . . 254

5.13 Contractual Limitations . . . . . . . . . . . . . 255

5.13 .1 Licencing Agreements . . . . . . . . . . . 256

5.13 .2 Delimitation or Coexistence Agreements . . . . . . . . 258

5.13 .3 Findings - Relation to Brand Value . . . . . . . . . . 259

5.14 Trade Mark Surveillance and Genericide Prevention . . . . . . 260

5.15 Summary . . . . . . . . . . . . . . . . . 262 
7.1 Einführung in die Thematik . . . . . . . . . . . . 271

7.1.1 Grundlagen der Wertbildung jedes Vermögensgegenstands . . . . . . . . . . . . . . . . . . . 272

7.1.2 'Forecasting'- und 'Reporting'-Bewertungen . . . . . . 273

7.1.3 Von einer forecasting-Bewertungsmethode zu erfüllende Voraussetzungen . . . . . . . . . . . . . . . 273

7.2 Grundlegendes zur Markenbewertung . . . . . . . . . . . 274

7.2.1 Immaterielle Güter und gewerbliche Schutzrechte . . . 274

7.2.2 Wesensart von Marken und Brands . . . . . . . . . . . 275

7.2.3 Einführung in die Markenbewertung . . . . . . . . . 276

7.2.4 Anlässe zur Markenbewertung . . . . . . . . . . . . . 277

7.3 Markenbewertung - der derzeitige Stand . . . . . . . . 277

7.3.1 Überblick über die momentane Markenbewertungslandschaft . . . . . . . . . . . . . . 277

7.3.2 Analyse gängiger Markenbewertungsmethoden . . . . . 278

7.3 .3 Schlussfolgerungen . . . . . . . . . . . . . . . . . 279

7.4 Entwicklung eines eigenen Ansatzes . . . . . . . . . . . 280

7.4.1 Überblick über den Bewertungsprozess . . . . . . . . . 280

7.4.1.1 Finanzielle ertragswertbasierte Analyse . . . . 280

7.4.1.2 Prismatische Evaluation . . . . . . . . . . . 281

7.5 Die rechtliche Dimension des Markenwertes . . . . . . . . . . . 282

7.5.1 Qualitativer Schutzbereich - Unterscheidungskraft, Freihaltebedürfnis und graphische Darstellbarkeit . . . 283

7.5.2 Quantitativer Schutzbereich - die Markenklassen . . . 284

7.5.3 Geographischer und zeitlicher Schutzbereich . . . . . . 284

7.5.4 Entstehung des Markenschutzes: registrierte und nicht registrierte Marken . . . . . . . . . . . . . 285

7.5.5 Benutzung . . . . . . . . . . . . . . . 285

7.5.6 Inhaberschaft und andere Rechtstitel . . . . . . . . 286

7.5.7 Amts- und Gerichtsverfahren; Vergleich . . . . . . . . . 286

7.5.8 Verwechslungsgefahr und Markenschutz darüber hinaus 286

7.5.9 Vertragliche Einschränkungen . . . . . . . . . . . 287 


\section{List of Figures}

2.1 Brand image . . . . . . . . . . . . . . . . 67

2.2 Brand identity . . . . . . . . . . . . . . 71

3.1 Brand valuation methods. . . . . . . . . . . . . . . . 118

3.2 Brand Iceberg by Icon Added Value . . . . . . . . . . . . . . . 154

3.3 The four modules of the ACNielsen Brand Performance System . . . . . . . . . . . . . . . . . . 159

3.4 Overview of the Interbrand valuation methodology . . . . . . . 164

4.1 One-Party Scenarios. . . . . . . . . . . . . . . . 178

4.2 Two-Party Scenarios. . . . . . . . . . . . . . . . . 179

4.3 Demonstration of the prismatic evaluation . . . . . . . 186

4.4 Example of combination of scoring results . . . . . . . . . 189

4.5 Using the two-point form of a linear equation to merge the scoring results . . . . . . . . . . . . . . . . . 190 



\title{
Table of Abbreviations
}

\author{
$A G \quad$ Aktiengesellschaft [public company] \\ Am.Econ.Rev. American Economic Review \\ $A / N$ author's note \\ Art. Article \\ Artt. Articles \\ $B B$ Betriebsberater \\ $B C$ Zeitschrift für Bilanzierung, Rechnungswesen und Controlling \\ BewG Bewertungsgesetz [German Valuation Act] \\ $B G B l$. Bundesgesetzblatt [German Federal Law Gazette] \\ $B G H$ Bundesgerichtshof [German Federal Supreme Court] \\ $B K R$ Zeitschrift für Bank- und Kapitalmarktrecht \\ $B M W$ Bayerische Motorenwerke \\ BPatG Bundespatentgericht [German Federal Patent Court] \\ cf. confer \\ CFI Court of First Instance of the European Communities \\ $C P M$ Comparable Profits Method \\ CTM Community Trade Mark \\ CTMD Community Trade Mark Directive \\ CTMR Community Trade Mark Regulation \\ CUT Comparable Uncontrolled Transaction Method \\ $D C F$ discounted cash flow \\ DIN Deutsches Institut für Normung \\ [German Institute for Standardisation] \\ DPMA Deutsches Patent- und Markenamt \\ [German Patent and Trade Mark Office] \\ $D P M A V$ Verordnung über das Deutsche Patent- und Markenamt \\ [by-law concerning the German Patent and Trade Mark Office] \\ DStR Deutsches Steuerrecht \\ $E B I T$ earnings before interest and taxes \\ $E C$ European Community \\ ECHR European Court of Human Rights \\ ECJ European Court of Justice \\ ECR European Court Reports \\ Econ.J. The Economic Journal
}


ed. editor

EEC European Economic Community

e.g. exempli gratia (for example)

EPC European Patent Convention

Erbschaftsteuerreform $G$ Erbschaftsteuerreformgesetz

[German Inheritance Tax Reform Act]

ErbStR Erbschaftsteuer-Richtlinien

[German Inheritance Tax Guidelines]

ErstrG Erstreckungsgesetz

[German Act extending the territorial scope of protection of intellectual property rights originally valid in former Western Germany to the territory of the former German Democratic Republic as of 3 October 1990]

et seq. et sequentes (and the following)

ETSI European Telecommunications Standards Institute

$E U$ European Union

EURIBOR Euro Interbank Offered Rate

e.V. eingetragener Verein [German registered association]

EVA Economic Value Added

$F A Q$ frequently asked questions

$F D I$ foreign direct investment

$F M C G$ fast moving consumer goods

$f n$. footnote

$G C$ Grand Chamber (of the European Court of Human Rights)

GfK Gesellschaft für Konsumforschung [Society for Consumption Research]

GmbH Gesellschaft mit beschränkter Haftung [German limited company]

GRUR Gewerblicher Rechtsschutz und Urheberrecht

GRUR Ausl. Gewerblicher Rechtsschutz und Urheberrecht, Ausländischer Teil

GRUR Int. Gewerblicher Rechtsschutz und Urheberrecht, Internationaler Teil

GSM Global System for Mobile Communications

$H G B$ Handelsgesetzbuch [German Commercial Code]

$I A S$ International Accounting Standards

$I A s$ intangible assets

$I A S B$ International Accounting Standards Board

IASC International Accounting Standards Committee

ibid. ibidem

$I D W \quad$ Institut der Wirtschaftsprüfer [Institute of Public Auditors in Germany]

i.e. id est (that is)

IFM Institut für Markentechnologie [Institute for Brand Technology]

IFRIC International Financial Reporting Interpretations Committee

IFRS International Financial Reporting Standards

IIC International Review of Intellectual Property and Competition Law 
InsO Insolvenzordnung [German Insolvency Act]

$I P$ intellectual property

$I P O$ initial public offering

IPRs intellectual property rights

$I R C$ Internal Revenue Code

IRS Internal Revenue Service

ISO International Organization for Standardization

IStR Internationales Steuerrecht

IVSC International Valuation Standards Committee

$K G$ Kommanditgesellschaft [German limited partnership]

$L O H A S$ lifestyle of health and sustainability

$M E A$ mergers and acquisitions

MarkenG Markengesetz [German Trade Mark Act]

MarkenR MarkenR - Zeitschrift für deutsches, europäisches und internationales Kennzeichenrecht

Marken $V$ Markenverordnung [German by-law concretising the implementation of the MarkenG]

$M A X$ Markenbildklarheits- und Attraktivitätsindex

$M B A$ Master of Business Administration

MP3 MPEG-1 Audio Layer III or MPEG-2 Audio Layer III

$N G O$ non-governmental organisation

$N P V$ net present value

$N Z G$ Neue Zeitschrift für Gesellschaftsrecht

$O E C D$ Organisation for Economic Co-Operation and Development

ÖOGH Österreichischer Oberster Gerichtshof

[Austrian Supreme Court]

OHIM Office of Harmonization for the Internal Market (Trade

Marks and Designs)

OJ Official Journal (of the European Union)

$p$. page

PatG Patentgesetz [German Patents Act]

PatKostG Patentkostengesetz [German Patent Cost Act]

$P C$ personal computer

PCT Patent Cooperation Treaty

pp. pages

q.v. quod vide (see)

$R \& D$ research and development

$R F I D$ radio frequency identification

RHM Rank Hovis McDougall

$R O I$ return on investment

RTL Radio Télévision Luxembourg

$S A$ société anonyme [public company established under French or Belgian law]

sec. section

$s F R$ Swiss Francs 
SigG Signaturgesetz [German Electronic Signature Act]

SIM Systematic Integrated Methodology

$S M S$ Short Message Service

$S P C$ supplementary protection certificate

$S P V$ special purpose vehicle

TLT Trademark Law Treaty

TRIPs Agreement on Trade Related Aspects of Intellectual Property Rights

UK United Kingdom

UMTS Universal Mobile Telecommunications System

USA United States of America

US-GAAP United States Generally Accepted Accounting Principles

$V D E$ Verband der Elektrotechnik Elektronik Informationstechnik e.V. [Association for Electrical, Electronic \& Information Technologies]

vs. versus

WIPO World Intellectual Property Organization

WiSt Wirtschaftswissenschaftliches Studium

$W M$ Zeitschrift für Wirtschafts- und Bankrecht

WRP Wettbewerb in Recht und Praxis

WTO World Trade Organization

ZfB Zeitschrift für Betriebswirtschaft 


\section{Chapter 1}

\section{Introduction}

In today's globalised world, markets are becoming increasingly narrow due to rising competition and numbers of goods and services offered. More than ever, businesses are forced to clearly define and strengthen their competitive advantages of which brands are core drivers. There are more and more products which are so similar that differentiation can only be achieved by means other than product characteristics. Such means primarily include brands. For instance, consumers find petrol of comparable quality at most petrol stations. Hence, the major means of making the product unique and attractive to buyers is the brand. This shows why brands are decisive for most companies' success - an insight true not merely regarding business-to-consumer markets, but also with respect to business-to-business markets. It is therefore not surprising that brands constitute the most valuable assets in many modern businesses. ${ }^{1}$

Furthermore, there exists a range of technical inventions (which result in innovation once marketed) for which patent protection cannot be obtained or has run out. Brands are of high importance in this context in order to signal these innovations to competitors and the target audience, thus securing as much exclusivity and freedom to operate as possible. Strong brands are, for instance, of high importance for the pharmaceutical generics industry. With regard to patented inventions, strong brands are the ideal complement, enhancing patents' return on investment and strengthening the overall economic success of the business.

1 PricewaterhouseCoopers/GfK/Sattler/Markenverband (ed.), Praxis von Markenbewertung und Markenmanagement in deutschen Unternehmen, p. 8. 
Brands are and always have been a core marketing tool. Yet today's business decision makers increasingly realise that brands and intellectual property $(\mathrm{IP})^{2}$ are much more than that: They are assets which can and need to be managed, traded and used as collateral. ${ }^{3}$

Along with this increased use of and focus on brands comes a growing demand for their valuation. Tight global competition forces businesses to maximise synergy effects by restructuring, e.g. through joint ventures, mergers or acquisitions (both horizontially and vertically), in the course of which brands are being transferred and, in consequence, given a price tag. To name a few examples which made international headlines in recent years, Procter $\mathscr{G}$ Gamble bought its competitor, shaver and battery maker Gillette, in 2005 for US\$ 57 billion $^{4}$ and sold its hygiene paper and tissue business, comprising brands such as Tempo, Charmin and Bounty, to competitor Svenska Cellulosa for $€ 512$ million in 2007. ${ }^{5}$ In 2004, IBM sold its personal computer business line to Lenovo for US $\$ 1.75$ billion in order to reposition by concentrating on consulting and other services, software and the manufacturing of servers and mainframe computers. ${ }^{6}$

More than ever, budget pressure forces today's brand and marketing managers to make their decisions watertight. It is increasingly being realised that the valuation of brands and related IP plays a decisive role in that concern. In addition, new accounting rules like IFRS/IAS 38 require capitalisation of all acquired IP, which presupposes valuation. A number of other activities like the exploitation of brands by way of licensing cannot be adequately carried out without a value finding process.

Like all other valuation, brand valuation is a complex and interdisciplinary art. A thorough understanding of brand valuation must begin - as with respect to all other complex systems - with the fundamental framework. Such knowledge base will be provided in the first two chapters, which all

2 Unlike trade marks, brands do not belong to the group of IP but are intangible assets, cf. 2.1.1.1 and 2.1.1.2.

3 Brückner calls this a 'paradigm shift from intellectual property to intellectual capital', cf. Brückner, VPP-Rundbrief Nr. 4/2005, 149, 149.

4 http://www.faz.net/s/RubC8BA5576CDEE4A05AF8DFEC92E288D64/Do $\mathrm{c} \sim \mathrm{E} 4 \mathrm{FC} 8 \mathrm{E} 3 \mathrm{~A} 8 \mathrm{~F} 57741 \mathrm{C} 899055 \mathrm{C} 5 \mathrm{~B} 59 \mathrm{D} 17 \mathrm{CDB} \sim \mathrm{ATpl} \sim$ Ecommon $\sim$ Scontent.html (last accessed January 28, 2008).

5 http://www.spiegel.de/wirtschaft/0,1518,471260,00.html (last accessed January 28, 2008).

6 http://www.heise.de/newsticker/meldung/54052 (last accessed January 28, 2007). 
other chapters are built upon. This will equip the reader with information necessary to successfully concern himself with the theory and practice of both brand and IP valuation.

\subsection{Objectives and Structure of this Thesis}

\subsubsection{Objectives}

\subsubsection{Structured Examination of Fundamental Valuation Issues}

The importance of the extremely complex art and science of brand valuation is increasingly being recognised. Coming along with this is a soaring amount of literature from around the globe, dealing with all major aspects of brand valuation and exploitation. Keeping in mind this fact, which is reflected by the more than three hundred currently existing brand valuation methods, ${ }^{7}$ it seems that the more one looks into the issue of brand valuation, the more questions and unresolved issues appear ${ }^{8}$ and the more apparent the need for systematisation becomes. This is why one major objective of this work is the structured discussion of fundamental issues pertaining to valuation of intellectual property. Once the basis for a thorough understanding of value will thus be set, detailed issues relating to IP value can and will be analysed, exemplified with trade marks and brands respectively.

\subsubsection{Improvement of Tradability of IP as Assets: Reduction of Information Asymmetries and of Risks}

As will be discussed in detail in chapter three, there is a clear implementation gap, i.e. a discrepancy between the current status of considerable disaccord as to the most suitable brand valuation thinking and method(s) and the desired stage of systematic well-accepted approaches to and methods of brand valuation. The study at hand identifies and analyses that problem. ${ }^{9}$ It intro-

7 Amirkhizi, "Suche nach der Weltformel". Cf. also infra at 3.1.1. and fn. 341.

8 One could say, along the lines of Socrates, "I know what I do not know" (Platon, Apology of Socrates: "Obviously I am ... a little wiser, for I do not believe to know what I do not know.").

9 A problem exists wherever there is a recognised disparity between the present and the desired state. Hence, solutions allocate all available resources in order to reduce this disparity, cf. Michalewicz/Fogel, Modern Heuristics, p. 1 et seq. 
duces a systematic integrated instrument to contribute to its solution, i.e. to the improvement of brand and IP valuation quality (and thereby to the frequency of its practical application). Key to such improvement of quality in the course of management strategic, or future-related, valuations is the reduction of asymmetries of information ${ }^{10}$ and of risks. ${ }^{11}$

Such improved valuations, if widely recognised and applied, allow for increased market transparency ${ }^{12}$ and tradability of intellectual property ${ }^{13}$ assets. In addition, they enable enhanced risk assessment, which helps businesses to lower their cost of capital. ${ }^{14}$

\subsubsection{Value Implications of Trade Mark Law}

Academic writers on brand valuation hardly ever touch the issue whether there are legal aspects which influence brand value and, if there are, which implications such influence has. ${ }^{15}$ However, a few brand valuation methods utilised in practice contain some references to legal aspects such as the questions whether and where there exists a registered trade mark.

This work shall, therefore, make a point of systematically and comprehensively scrutinising aspects of trade mark law which could have a relation to brand value, in order to find out whether there is such relation and, if yes, which implications it has. It shall thereby be elaborated whether the importance of legal aspects is duly reflected in academic writings and especially in practice.

10 Cf. 1.4.1.5.

11 These inevitably accompany any future-related valuation, as it constitutes an estimate, cf. 1.2 .

12 As intellectual property rights are highly unique and contextual, it would be unrealistic to postulate markets for intellectual property which are as transparent as markets for frequently traded tangible assets such as real estate. However, the current situation can be improved by providing a means to facilitate tradability through reduction of risks and of asymmetry of information. This will be discussed in chapter four.

13 The problems of market intransparency and market failure exist not only with respect to trade marks and brands but also regarding (other) intellectual property in general.

14 Cf. 1.4.1.5.

15 The only European legal publication accessible to the author of this work is Reese, Die Bewertung von Immaterialgüterrechten, which deals with valuation of patents, trade marks, copyright and designs and treats legal aspects of value in a rather cursory way. 


\subsubsection{Valuation and Evaluation}

Valuation, be it financial or non-financial, gives the appraiser a particular, on-the-spot analysis of the asset's worth. However, it is usually not able to provide information on the asset's role within the business strategy of the proprietor. However, such information is very useful for a comprehensive IP assessment in a forecasting situation. Particularly, utility and value of intellectual property are, compared to those of tangible assets, especially dependent on the context in which these assets stand (such as existing or missing support by other assets) - both within the proprietor entity and beyond. ${ }^{16}$

In consequence, assessment of intellectual property for strategic, or forecasting, purposes should not amount to mere valuation but rather be complemented by evaluation in case a comprehensive contextual assessment is desired. Intellectual property evaluation denotes the process of tying valuation into the overall strategy of a company. With respect to brands, for example, this means that the effectiveness of marketing and brand management strategies can thus be controlled and managed. ${ }^{17}$

References as to how intellectual property can properly be evaluated will therefore be made throughout this work.

The statement that one can only manage what one can value has been a central incentive for writing this book. The author hopes to give interested brand managers, investors and other strategic decision makers thought-provoking impulses and tools to improve understanding of intellectual property valuation coherences as well as practical strategic decision making.

\subsubsection{Structure}

The structure of this study is dictated by its main objectives. These are, as stated above, to systematically discuss and analyse the fundamental issues of intellectual property and brand valuation and to improve tradability of brands and intellectual property as assets.

16 Cf. 1.4.1.2.

17 Cf. e.g. Brand Finance, Current Practice in Brand Valuation, p. 21 et seq. and Esch/Geus, Ansätze zur Messung des Markenwerts, p. 1269. 


\subsubsection{Provision of Essential Knowledge}

As it is essential to deal with general and fundamental coherences prior to detailed issues, it is first of all necessary to understand why valuation is important and being carried out, what is being valued, and how - in short: the 'why, what and how' of valuation.

It is not until the interested person has accrued knowledge on this meta-level of valuation that he or she is ready to engage in detail, e.g. the examination of single valuation methods. For this reason, as well as for purposes of systematisation, this study is intended to provide the 'why, what and how' of valuation - by the example of trade marks and brands - in a methodical way before it introduces the reader to actual valuation instruments.

In consequence, all fundamental coherences as to the 'why' and the 'what' of valuation are provided in chapters one and two of this study, next to the first part of the 'how', the explanation of objectives a proper valuation methodology is supposed to meet.

\subsubsection{Definition of the Desired Stage}

Every thorough problem solving approach requires proper understanding and definition of the purpose to be achieved and the desired stage of affairs which is being aimed at. ${ }^{18}$ Hence, it will be clearly stated in which situations brand valuation is needed, which requirements a desired brand and IP valuation method should meet and why. ${ }^{19}$

\subsubsection{Examination of the Current Stage}

Chapter three, as a logical next step, will provide an introduction and analysis of the basic brand valuation approaches and a number of popular brand valuation methods ${ }^{20}$ presently in use. This part serves the purpose of both illuminating the current state of the art of brand valuation and analysing its positive and negative causes and features.

18 Michalewicz/Fogel, Modern Heuristics, p. 2 et seq.

19 See 1.4 and 2.3 .

20 As to the difference between an approach and a method cf. 3.2.2. 


\subsubsection{Introduction of Means to Overcome this Gap}

Insights gained from this analysis will then, coupled with valuation fundamentals discussed earlier, be used to introduce a systematic integrated valuation methodology in the following chapters four and five. This methodology serves as the author's contribution to the desired improvement of IP valuation quality (by mitigation of risks and information asymmetries) and thereby to increased tradability of such assets and reduction of cost of capital.

As the systematic integrated methodology is, in its essence, applicable to valuation of all intangible assets and intellectual property, it can, for instance, also be applied with respect to patents. The problems of lack of suitable valuation instruments, excess market intransparency and cost of capital exist regarding both patents, brands and other intangible assets.

Hence, not only the content-related but also the quantitative focus of this work lies on the fundamentals of IP valuation as well as on the methodology newly introduced in chapters four and five, especially its legal dimension. These issues will, for the most part, be illuminated and discussed on the basis of (trade marks and) brands.

\subsection{Distinguishing Reporting from Forecasting Valuations}

Ideally, instead of utililsing different valuation tools for different valuation occasions, one is able to elaborate at least one category of valuation scenarios which all show a sufficient degree of commonality in order for them to be covered by one single valuation tool. This would be conducive to both clarity of valuation processes, usefulness of the respective method and comparability of valuation outcomes. ${ }^{21}$

In this connection, it is important to realise that valuation for accounting and taxation purposes is to a certain extent regulated by existing legal frameworks and statutes, both on national, supranational and international levels. For instance, IP valuation in the accounting field is internationally regulated by the standards IFRS 3 and IAS $38 .^{22}$ These sets of rules prescribe certain valuation techniques, such as the cost method for initial valuation of intangible

21 Cf. 1.4.3.2.

22 More on valuation for accounting and taxation purposes below at 2.3.5. 
assets in an accounting setting, ${ }^{23}$ to be utilised in many areas they apply to. Accounting and taxation rules are self-contained bodies leaving comparatively little room for methodical preferences of the appraiser and should therefore be treated as a group distinct from valuation scenarios which are not governed by binding legal bodies. ${ }^{24}$

What is more, the appraiser generally works with historic data and mostly serves the purpose of covering past events. ${ }^{25}$ Due to this fact, valuations for the purpose of assessment of damages or the amount in dispute in legal proceedings should be - as they are also based on mainly historic data - added to accounting and taxation valuations in order to form one group. Based on its focus on past events, this category shall be called 'reporting' valuations in order to differentiate it from future-related valuations.

The latter include all those scenarios in which the appraiser is tasked with estimating future value. These are all future-oriented occasions in the broadest sense, i.e. strategic ones such as licensing and other prospective transactions, strategic and operative management and controlling, as well as finance and protection strategies. ${ }^{26}$ Valuations carried out in this category are not regulated by binding laws. They shall, in contrast to reporting valuations, be named 'forecasting' valuations.

All forecasting valuation occasions have in common that future value has to be determined on the basis of presently available data. Hence, they by necessity constitute an estimate. This means that - contrary to mainly pastrelated valuation fields such as accounting and tax - the outcome cannot be expressed in one fixed sum. Rather, future-related valuation must result in a

23 Cf. IAS 38.24 in combination with IAS 38.65 .

24 Furthermore, the purchase price of a brand is in most cases not identical to the value of the respective brand as laid down on the balance sheet. Cases may arise in which the balance sheet value is zero whereas the brand is sold for a considerable sum. Examples which show that brands have been sold for a multiple of the book value is the takeover of Rowntree by Nestlé for US $\$ 4.5$ bn. - the fivefold of the book value - and the acquisition of Kraft by Philip Morris for US $\$ 12$ bn. - four times the book value, cf. Berger, MarkenR 1999, 271, 271. Quod vide Franzen, DStR 1994, 1625, 1625. The examples just mentioned show that there must be a difference between the accounting value and the one arrived at in the course of a sale. The balance sheet cannot and does not make a valid statement about the strategic future-related value of the respective brand.

25 This shall not ignore that accounting is in part future-related. However, this is not the main focus. As Barsky and Marchant put it, "Accountants are paid to track the past, but managers are paid to build the future.", cf. Barsky/Marchant, The Most Valuable Resource - Measuring and Managing Intellectual Capital. 
value spread. An exact value figure will not be detectable until the moment of transaction (if there is one), in which the asset must be given a specific price tag.

This, in turn, means that the quality of a forecasting valuation technique can be detected by how well it is able to deal with and minimise future-related uncertainties and risks.

The reporting-forecasting dichotomy is so profound that it justifies and even necessitates a differentiation betweeen these two fields. It applies to all valuation objects, tangible and intangible.

The work at hand is committed to dealing with forecasting intellectual property valuations.

\subsection{General Framework Underlying the Value of any Asset}

Next to universal value determinants of intellectual property and other intangible assets, ${ }^{27}$ there are general principles underlying the formation of value of any asset, tangible and intangible. These factors are scarcity, utility and title.

\subsubsection{Scarcity}

As a general rule, tradable assets are more valuable the more demanded or scarce they are respectively. If supply rises above demand, scarcity and prices decline. ${ }^{28}$ Assets which are not scarce have no potential to attain noticeable value. Therefore, scarcity is a fundamental source of and conditio sine qua non for value.

Physical assets are either scarce eo ipso if there are merely a few or only one item in existence or can be made scarce by physically moving them from a place of abundance to a place of scarcity or by limiting production. Therefore, the scarcity of physical assets is a factual one. Exercise and control of this scarcity can be facilitated by allocating property rights.

28 Paschke, Grundlagen der Volkswirtschaftslehre, p. 36 et seq. 
In contrast to this, intangible assets by their very nature cannot be made scarce through physical means; they are by definition free. Apart from secrecy, it is not until the law allocates intangibles to a specific proprietor or title holder by creating intellectual property rights that they can become scarce. ${ }^{29}$

\subsubsection{Utility and Title}

An asset which shows scarcity but is hardly useful at all will not be able to attain considerable value. Every asset has a certain degree of (positive or negative) utility for the proprietor or title holder, i.e. it serves a certain useful purpose to varying degrees, depending on proprietor, objectives and situation. For example, a brand can be used as a marketing means in order to increase sales yet the proprietor may decide to licence it out or create a franchising scheme instead or simultaneously. In every situation, the brand creates a different degree of positive utility effects, be it increased turnover, market penetration or bargaining power vis-à-vis suppliers or other. Hence, the more useful the respective IP right is, the more valuable it is at the same time. Therefore, it is essential for a thorough valuation to determine whether the proprietor is able to use and exploit the IP asset in question to its full potential.

This shows that the issue of utility is intertwined with the question of title: An IP right may be useful for one company, e.g. because it augments its patent portfolio with a technology needed to make a certain other patented technology work, but useless for another company the core competence of which lies in a completely different field of technology.

The issues of ownership and title have further important implications on value. The question whether one or several owners exist is crucial for both liability and other legal issues and financial questions such as distribution of earnings. A factual ownership implication may be that a bank may lend money against an IP right or portfolio owned by a well-known company but be reluctant with respect to unknown start-up companies.

Furthermore, exploitation of an IP asset presupposes correct title. Hence, the value of an IP right cannot be comprehensively assessed without looking at the contextual issue of title. For every IP right existing there is a title 
holder, be it a natural or a legal person. The concept of title comprises any legal rights construction, be it full ownership or merely the role as a licensee. No matter of which kind the title exactly is, title is another key element of intellectual property (and even of any property): It defines what the title holder is allowed to do and how he or she may exploit the respective IP right, be it through direct sale, licensing, securitisation or other. In short: The quality of title defines the freedom to operate with the respective asset.

\subsubsection{Intermediate Findings}

In the light of the fact that occupying oneself with the constitutive elements of value is essential for thorough understanding and proper application of valuation, scarcity, utility and title are the three elements the interplay between which directly influences the value potential of any asset, tangible and intangible.

Value results from an interplay between scarcity, utility and title, or, in short, value equals scarcity times utility times title.

It is essential to realise that this conceptual value definition must be differentiated from the practical case-by-case realisation of value, usually expressed in monetary terms. It is not until the respective asset is actually traded and therewith priced (in units of money or other consideration) that its value, which was until that moment a conceptual and estimated one, materialises and concretises. Scarcity, utility and title are thus reflected in the attained price. $^{30}$

The quality of a valuation instrument shows, amongst others, in how well and comprehensive it is able to operationalise scarcity, utility and title of the respective asset.

\subsection{Requirements a Forecasting Valuation Technique Must Meet}

Objectives a desired valuation instrument should meet (and should not meet respectively) will be illuminated in the following. They will be used later to

30 A more detailed discussion and a definition of brand value, which shall not be anticipated at this point, can be found at 2.2.2.1. 
scrutinise both currently applied brand valuation tools and the Systematic Integratred Methodology introduced in this work.

Such requirements are dictated by the valuation method's cause and objective. Any future-related intellectual property (e)valuation tool should provide conceptual and methodical soundness, widespread acceptance and a manageable output.

\subsubsection{Conceptual and Methodical Soundness}

Conceptual and methodical soundness, i.e. a convincing and proper methodical framework, is a universal requirement to be met by all valuation techniques. In detail, this means that, for purposes of practical usability, they should possess a standardised repeatable (i.e. reliable) yet flexible modus operandi and be workable with economically justifiable effort. ${ }^{31}$ In addition and with respect to future-related evaluation techniques in particular, comprehensiveness, context, transparency, reduction of asymmetry of information and of risk and provision of an appropriate degree of objectivity have also been selected as mandatory requirements.

\subsubsection{Comprehensiveness}

As mentioned above, one of the main objectives of this work is the improvement of valuation quality by reduction of risk and of asymmetry of information. In consequence, it is desired to collect as much information about the asset under scrutiny as possible. Such modus operandi allows the valuation client to base his or her decisions on the best possible information groundwork.

For instance, the application of a comprehensive (e)valuation routine would probably have saved Volkswagen from wasting considerable sums of money as in the year 1998 it discovered the cost of poorly executed transactions since it had won a US $\$ 790$ million bidding war against $B M W$ for the purchase of Rolls-Royce Motors, assuming it had secured the ROLLS-ROYCE and BENTLEY trade marks which in fact was not so. ${ }^{32}$

31 Esch/Geus, Ansätze zur Messung des Markenwerts, p. 1282.

32 Liberman, IP issues in mergers and acquisitions, p. 7 et seq. 
With respect to brands, in particular (of which trade marks are part ${ }^{33}$ ), the valuation method needs to be applicable to all types of (registered and unregistered) trade marks, from simple word marks to three-dimensional signs, new forms like holograms and their combinations, as well as to single brands and brand portfolios.

\subsubsection{Context}

Inclusion of contextual (and not merely financial) variables in the valuation process is essential with respect to intellectual property assets, since they are by their very nature highly contextual. This means that they are (unlike most tangible assets), in their utility, strength and value, relatively heavily dependent on the factual and legal contexts in which they stand.

For example, a pharmaceutical brand for pain remedies can only be expediently utilised if there are corresponding products or services. Hence, adequate plant and machinery, know-how, patents and other assets are of the essence without the operation of which the mere brand would be of no avail. This applies similarly with respect to patents. Therefore, the commercialisation of intellectual property assets cannot be properly carried out without the support of complementary intangible and tangible assets (this support is needed to varying degrees, depending on the commercialisation strategy). ${ }^{34}$

Furthermore, the abovementioned pharmaceutical brand could only be used to its full potential if it belongs to a pharmaceutical business operating in a compatible market, utilising the brand as a core business driver and as part of an overall brand and company strategy. It would be useless in the hands of, for instance, a biotechnology business producing antibodies for cancer treatment. The value of IP assets is consequently interrelated with nature and strategy of the proprietor.

\subsubsection{Transparency}

As a general rule, quality and validity of the brand value output depend on a clear definition and categorisation of value influencing factors (i.e. the

33 For a detailed elaboration of the relationship between trade marks and brands cf. 2.1.2.

34 Achleitner/Nathusius/Schraml, Quantitative Valuation of Platform Technology Based Intangibles Companies, pp. 7 and 9. 
input), ${ }^{35}$ as well as on a high-quality valuation process. In addition, the better the valuation client is aware of how the end result comes about, the more he is able to verify it and trust in its quality. Not surprisingly, a German study showed that transparency was perceived as the second most important requirement to be met by brand valuation techniques. ${ }^{36}$

Even more importantly, transparent input and process yield all information necessary for the client to be able to integrate the valuation object into its greater context and the company strategy, which means he is able to properly evaluate the asset and to act accordingly.

From a scientific point of view, it is desirable to reach full transparency, as this would allow proper scrutiny and comparisons of the respective techniques. However, it should be acknowledged that this would be too much to demand from commercial valuation service providers, since they base their business models upon their valuation methods. All such service providers are keeping their methodologies secret to some degree (a so-called 'black box'37). Hence, the question is whether this portion of secrecy is excessive or not. ${ }^{38}$

\subsubsection{Flexibility}

Since intellectual property assets are highly contextual and therefore demand operationalisation of various value influencers apart from financial ones, it is important to realise that it is likely that such factors change over time, both in content and importance. Hence, a valuation methodology needs to be able to answer to and allow for changes.

For instance, an alteration of product quality may have positive long-term influence on brand value, e.g. in case of improvements which lead to increased sales after a certain time lag. Other - rare - examples such as the PERRIER disaster $^{39}$ demonstrate the possibility of immediate and long-term negative

35 Bentele/Buchele/Hoepfner/Liebert, Markenwert und Markenwertermittlung, p. 152.

36 Günther/Kriegbaum-Kling, Schmalenbach Business Review 2001, 263, 284. Transparency was ranked second, together with objectivity.

37 A black box is any device whose workings are not understood or accessible to the user or client. Black box calculation methods use predefined inputs and outputs whereas the process in between is unknown, cf. Toh, Fuel Cell Controller, p. 35.

38 The analysis in chapter three will go into this matter.

39 In 1990, millions of bottles of PERRIER mineral water had to be recalled in a number of countries such as the USA and Canada because their content was contaminated with the chemical benzene which is under suspicion to cause cancer. The damage to 
influence on brand value in case of a sharp fall of product quality, especially in mass markets.

It follows that a valuation instrument cannot be comprehensive and yield realistic results without taking both short- and long-term changes into account.

Furthermore, it should enable the appraiser to include value determinants the importance of which has emerged over time and exclude those which have become comparatively unimportant.

\subsubsection{Reduction of Asymmetries of Information and Reduction of Risks}

In the course of all future-related valuations, estimates have to be made on the basis of presently available data. As to intellectual property, in particular, the fact that market intransparency is considerably larger than with respect to tangible assets (however, even with respect to frequently traded tangible assets such as automobiles, full market transparency and symmetry of information is an illusion yet such markets provide enough information for all sides to be workable) results in distribution of information - if information is available at all - to be highly skewed. Hence, future-related IP valuation is characterised by considerable information asymmetries, which means the persons concerned do not nearly have the same amount and/or quality of information at their disposition. ${ }^{40}$

Such lack of quantity and/or quality of information results in low quality valuations, which negatively affects the negotiations or other situations in which the valuations are utilised. This lack also means increased risk, which results in overly high cost of capital. ${ }^{41}$ It may even mean that negotiations cannot be finalised at all. Hence, the degree to which one is able to minimise

the brand was even worsened by rather inept public relations activities on the side of PERRIER. Ultimately, the company had to spend £84 million on product repositioning as well as $£ 125$ million when the drinks division was sold, cf. Gream, Trademark valuation: review in January 2004, p. 4.

40 Reiche, DStR 2000, 2056, 2056; Kamp/Ricke, BKR 2003, 527, 527.

41 Not only does the fact that intellectual property is (partially) off-balance sheet detrimentally affect the market liquidity of the respective company's stocks, thus increasing its cost of capital (Hand/Lev, Introduction and Overview, p. 11). Cost of capital is also overly increased each time a financier demands relatively high risk premia due to the fact that he or she lacks the information necessary to properly assess all risks involved. 
given information asymmetries is decisive for quality and usability of both the respective valuation tool and the valuation end result.

The issue of information asymmetry is linked to risk reduction. As will be elaborated in more detail below, ${ }^{42}$ investment in intangible assets is considerably riskier than investment in tangibles. This risk of total loss bears on, amongst others, the general nontradability ${ }^{43}$ of intangibles and is comparatively rare with regard to tangible and financial assets. In addition, return on investment in intangibles, including intellectual property, has been proven to be highly skewed. ${ }^{44}$ Since these issues are crucial value determinants, risk assessment must and risk reduction should be central characteristics of a proper valuation tool.

As nontradability results from substantial lack of information or asymmetry of information respectively, mitigating information asymmetry by systematically collecting and processing as much information about the asset under valuation as possible contributes substantially to lowering nontradability and thus the abovementioned risks and their implications (such as excess cost of capital).

\subsubsection{Reliability vs. Accuracy}

A decisive factor in the course of intellectual property valuation which is at times being overlooked is the fact that it does not make sense to demand a higher degree of accuracy from IP valuation than from any other valuation, e.g. of real estate. Expressing the value of a patent or a brand in an exact Euro and Cent amount is only possible in a reporting (accounting and tax) context. Even a forecasting valuation of tangible assets traded in relatively transparent markets, such as cars or real estate, can by definition not be accurate. This is due to the fact that any future-oriented valuation is by its very nature an estimation. Hence, it cannot result in an exact value figure. ${ }^{45}$ This does not mean that accuracy is, in general, no legitimate valuation objective. Rather, it is an expedient goal which is by definition impossible to

42 At 2.1.1.3.6.

43 Cf. 2.1.1.3.4.

44 Scherer/Harhoff/Kukies, 10 Journal of Evolutionary Economics, 175 (2000); MP Marketing Partner AG, Studie: Rentabilität von Marken oft fraglich - Unternehmen im Zugzwang.

Q.v. e.g. above at 1.2. 
reach in the course of future oriented strategic valuations.

If forecasting valuations cannot be accurate, they should at least be reliable. One's attention therefore needs to be directed to the question how well a forecasting valuation technique is able to reliably define and narrow down the inevitable value spread (this approximates accuracy as closely as possible). The quality of the manner in which this issue is addressed is an important benchmark for overall quality of a valuation tool. ${ }^{46}$

In this connection, reliability means providing a reproducible process which, ceteris paribus, yields comparable end results whenever a valuation of the same asset is repeated. This means, for instance, that the valuation process must be trustworthy enough to yield a result reflecting only the time difference in case the same asset is valued, ceteris paribus, at different points in time.

\subsubsection{An Appropriate Degree of Objectivity}

Objectivity per se is a valid goal and requirement to meet for good valuation techniques. It ensures that possible arbitrariness resulting from human handling of the valuation process is reduced to a minimum. Not surprisingly, a study has shown that it belongs to the three brand valuation requirements which are perceived to be the most important ones. ${ }^{47}$

However, every forecasting valuation necessarily involves subjectivity. There is no such thing as a completely objective estimate, as each appraiser will assess certain conditions slightly differently. Hence, as absolute objectivity cannot be reached, the manner in which the respective valuation methodology balances the inevitably occurring subjectivity with the pursuit of objectivity is an important quality indicator of that tool. In other words, a good valuation method provides for as little subjectivity as necessary and as much objectivity as possible.

46 A study carried out in 1999, surveying German companies, has shown that respondents perceived reliability as the most important requirement for brand valuation methods, cf. Günther/Kriegbaum-Kling, Schmalenbach Business Review 2001, 263, 284.

47 Out of 13 requirements; Günther/Kriegbaum-Kling, Schmalenbach Business Review 2001, 263, 284. Objectivity was ranked second, together with transparency. 


\subsubsection{Widespread Acceptance}

A point which is largely criticised today is the fact that there exists a plethora of brand valuation methods but none of them is generally accepted. ${ }^{48} 49$ Reasons for this are both deficiencies of the models themselves and the fact that more and more companies are discovering brand equity consulting as a lucrative area of business and therefore offer their own proprietary method.

Having a widely accepted valuation tool would not only contribute to clearing up the existing thicket of methods. It would also ensure comparable valuation end results, both with respect to different valuation objects and over time (provided the valuation method is comprehensive enough to be applied on all types of brands and ideally all IP and in the course of all forecasting valuation situations). Comparability of valuation outcomes, ${ }^{50}$ in turn, facilitates strategic decision making, for instance in the course of resource allocation.

What is more, widespread utilisation of one IP valuation tool (or, more realistically, at least a very small number of them) would enhance the financial world's confidence in such valuations. Banks and other creditors would be more inclined to lend against IP assets than at present, which would contribute to lowering the debtors' cost of capital.

In addition, it could serve as a viable framework for IP asset markets, pro-

48 Schunk/Lütje/Heil, markenartikel 2004, 24, 30.

49 A number of standardisation efforts are therefore being made, both on national and international levels. For instance, the German Institute for Standardisation (Deutsches Institut für Normung - DIN) is working on a brand valuation standard. For this purpose, it established a working group in January 2005, cf. Deutsches Institut für Normung, DIN-Norm für Methoden der Markenwertmessung geplant. An Austrian Standard was publicised in March 2006 (Standard ONR 16800, see http://www.onnorm.at/publish/2518.html (last accessed May 2, 2006)). It is a financial formula based on company valuation methods. What is more, the German Institut der Wirtschaftsprüfer $(I D W)$ has issued a draft standard of valuation of intangible assets, cf. Institut der Wirtschaftsprüfer (IDW), Entwurf IDW Standard: Grundsätze zur Bewertung immaterieller Vermögenswerte (IDW ES 5). Furthermore, DIN has proposed to the International Organization for Standardization (ISO) (http://www.iso.org/is o/en/ISOOnline.frontpage (last accessed May 4, 2006)) to elaborate an international norm which lays down the basic requirements for methods of monetary brand valuation, cf. news of April 24, 2006 (http://www.on-norm.at/publish/2518.html and http://www.on-norm.at/publish/2948.html (last accessed May 2, 2006)). On the NGO level, the International Valuation Standards Committee is worth mentioning (http://www.ivsc.org (last accessed May 4, 2008)). Its International Valuation Standards contain - amongst others - guidance on the valuation of intangible assets, cf. International Valuation Standards Committee (IVSC), International Valuation Standards, Guidance Note 4. 
vided that the valuation method yields as much contextual information about the asset as it is proposed in the work at hand, as this is essential for assessing risks and lowering asymmetry of information, both of which are key market drivers. High risks and information asymmetries are the major reasons why workable large-scale IP markets do not exist. A widely accepted or even standard way of dealing with these issues could therefore mitigate these problems to an extent which makes markets for IP possible in a satisfactory way (even though participants in these markets would, in general, have to cope with higher information asymmetry and risk than those in markets for tangible assets due to the highly contextual nature of IP).

As expression of value in monetary terms is needed for most valuation purposes, a desired valuation tool should yield such a monetary outcome. Being able to be applied in many situations is prerequisite for becoming widely accepted.

\subsubsection{Manageable Output}

All scenarios in which a future-related valuation technique ${ }^{51}$ is needed involve a strategic management setting. Hence, a valuation method should provide a reliable basis for strategic decision making.

This is not only achieved by means of future orientation ${ }^{52}$ but also through comparability of outcomes.

\subsubsection{Future Orientation}

All strategic decisions are future-related. Valuation tools to be used in strategic scenarios need to take this into account. The implications hereof have already been introduced above at 1.1.1.6, to which shall be referred here.

The practical relevance of this requirement has been proven by a study of German companies which found future orientation to be the fourth most important requirement to be met by a sound brand valuation tool. ${ }^{53}$

51 As explained above at 1.2, this work solely concerns itself with future-related, or forecasting, valuations.

52 Esch/Geus, Ansätze zur Messung des Markenwerts, p. 1282.

53 Out of 13 requirements; Günther/Kriegbaum-Kling, Schmalenbach Business Review 2001, 263, 284. 


\subsubsection{Comparability of Results}

Ideally, a valuation methodology shall provide for both absolute and relative, i.e. comparative, valuations. An absolute valuation result can be obtained by means of single application of any valuation method. It reflects value as expressed by that method at one specific point in time and with respect to the one asset under scrutiny. However, it is not until several available valuation results are comparable that they are considerably more meaningful, as this allows for comparison of these assets vis-à-vis each other as well as for monitoring of the development of one or several assets' value over time. Both is indispensable for thorough strategic decision making and can best be achieved by continuous application of the same valuation technique. In light of this circumstance, the classification into forecasting and reporting valuations $^{54}$ was, amongst others, carried out in order to single out an expedient group of valuation scenarios which have enough in common for one specific valuation methodology to be applicable to all of them.

\subsubsection{Findings}

An ideal forecasting intellectual property valuation methodology should not only be widely recognised and utilised but also provide for conceptual and methodical soundness and a manageable end result. If these requirements are met, any intellectual property asset will be comprehensively and systematically assessable, for purposes of any strategic scenario, by means of one single tool.

This would not only thin out the existing thicket of valuation techniques. More importantly, it could make a considerable contribution to building confidence in the quality of IP and brand valuation, thus enabling IP market creation and increasing use of IP assets in finance (which could, for instance, lower proprietors' cost of capital).

What is more, as the respective method would provide contextual information about the asset under valuation in a transparent manner, the valuation client could be put in a position of not only being aware of a certain valuation outcome but also of the respective value determinants' status and possible relations of the valued IP to other assets, on a case-by-case basis. Hence, over 
and above valuation, this would enable him or her to evaluate the asset, i.e. to integrate it into the company strategy and to draw not only diagnostic but also therapeutic inferences for management and controlling purposes.

\subsection{Summary}

Intellectual property valuation is a highly complex art. All the more important it is to find a systematic approach towards it. In order to implement such systematic modus operandi, it is necessary to first of all concern oneself with constitutive value topics, prior to dealing with details. It has therefore been demonstrated that the interplay between the three factors scarcity, utility and title establishes the value of any asset, tangible or intangible.

In addition, it has been clarified, amongst others, that there exists a fundamental difference between strategic future-related, or forecasting, and pastrelated, or reporting, valuations. Whereas past-related valuations are able to yield an exact value outcome, forecasting valuations inevitably involve estimates and therefore must result in a value spread instead of a fixed figure. The work at hand solely concerns itself with forecasting valuation.

Following the train of thought from general to specific, the requirements a desired forecasting valuation methodology shall meet were also explained in this beginning chapter. Conceptual and methodical soundness, widespread acceptance and manageable output will be used later in this work to scrutinise both presently applied brand valuation techniques as well as the newly introduced Systematic Integrated Methodology.

Furthermore, this work attempts to help reduce risks and information asymmetries in order to increase tradability of intellectual property assets and to lower cost of capital by means of systematic, coherent and holistic examination of intellectual property valuation.

Another main objective is to scrutinise possible value implications of legal aspects of trade mark protection in a fashion as comprehensive as possible. The significance of trade mark law aspects in brand value could thereby be assessed. 



\section{Chapter 2}

\section{Brand Valuation Fundamentals}

\subsection{Nature of Trade Marks and Brands}

In order to understand what trade marks and brands are and what makes them valuable, it is indicated to first of all take a look at and understand the bigger picture, i.e. the system of rights and assets trade marks and brands are part of. This is the area of intangible assets (IAs) and intellectual property.

\subsubsection{Intangible Assets and Intellectual Property}

Intangible assets and intellectual property are not synonyms. Rather, as will be elaborated shortly, IP is a subset of the group of intangible assets. ${ }^{55}$

\subsubsection{Intangible Assets}

"In recent decades [...] the fraction of the total output of our economy that is essentially conceptual rather than physical has been rising. This trend has,

55 Intangible assets are dealt with in this work since a number of important characteristics of intangibles which affect their value are also valid with respect to intellectual property. Hence, intangibles will not be covered at length but always in light of the topic of this work, intellectual property value. Should the reader wish to read more about intangible assets, there are a number of articles and monographies which cover this topic at length, such as Harrison/Sullivan, 32 Industrial and Commercial Training, iss.4, 139 (2000); Andersen/Striukova, Intangible Assets and Intellectual Capital: Where Value Resides in the Modern Enterprise; Brooking, Intellectual capital; Lev, Intangibles - Management, Measurement, and Reporting and Manton, Integrated intellectual asset management: a guide to exploiting and protecting your organization's intellectual assets. 
of necessity, shifted the emphasis in asset valuation from physical property to intellectual property and to the legal rights inherent in intellectual property. Though the shift may appear glacial, its impact on legal and economic risk is beginning to be felt." 56

Today we are used to businesspeople, lawyers, economists and politicians alike speaking about the increased importance of intangible assets ${ }^{57}$ and intellectual property. We have got used to a world in which more and more companies in industrialised countries derive the lion's share of profit from these assets. Therefore, questions as to the nature of IAs, their difference from IP and their importance arise.

In the past two decades, there has been a distinct shift of focus of importance away from tangible towards intangible assets as part of the overall value of companies in modern economies. About twenty years ago, tangible assets made up approximately $60 \%$ of the average company's value. Today, intangible assets account for up to $90 \%$ of the value of many modern corporations, ${ }^{58}$ taking into account that aberrations may arise, depending on the respective valuation technique. The reason for this is a dramatic structural change of modern economies, at least in the developed world. Intensified national and global business competition, the emergence of digital information technology and deregulation of industries have caused intangibles to become the major value drivers in modern businesses: Existing traditional production-focussed corporations are forced to adapt by deverticalisation and innovation, both of which intangible assets are fundamental factors. ${ }^{59}$ For example, innovation is primarily achieved by investment in intangible assets such as research and development $(\mathrm{R} \& \mathrm{D})$ and employee training.

It needs to be noted, however, that part of the reason why the share of intangible assets within modern companies has become so high needs to be attributed to the fact that these assets have only been put into the centre of attention on a global scale relatively recently. Intangible assets such as skills

56 Former US Federal Reserve Chairman Alan Greenspan on February 27, 2004 at the Stanford Institute for Economic Policy Research; speech to be retrieved at http:// www.federalreserve.gov/BoardDocs/speeches/2004/200402272/default.htm (last accessed March 13, 2007).

57 Synonyms used for intangible assets are 'intellectual assets', 'intellectual capital', 'knowledge assets' or merely 'intangibles'.

58 See e.g. Anson, Intellectual Capital: Understanding the Value and the Risk and Grauel, brand eins 2003, issue 2, 65, 66 .

59 Lev, Intangibles - Management, Measurement, and Reporting, p. 9, p. 11 et seq. 
owned by the workforce and distribution channels have always existed. Yet a few decades ago, they were hardly perceived as assets at all and consequentially not treated as such.

Intangible assets are - contrary to tangible assets like real estate, plants and machinery - claims to future benefits that do not have a physical or financial (stock or bond) embodiment, ${ }^{60}$ e.g. patents, brands, business secrets, broadcasting licences, distribution channels and so forth. ${ }^{61}$ Although these assets are intangible, there should be some proof of their existence, e.g. a registration, contract, database etc. Some scholars define intangible assets as all those "elements of a business enterprise that exist after monetary and tangible assets are identified". ${ }^{62}$ This is a rather good definition for the purpose of understanding the general nature of intellectual assets, but one has to bear in mind that it is potentially precarious in the valuation context. ${ }^{63}$

Some writers categorise intangible assets into subgroups in order to clarify their nature. Smith for example subdivides the set of intangible assets as a whole into rights, relationships, grouped intangibles and intellectual property. ${ }^{64}$ Lev distinguishes innovation-related, organisational and human resource intangibles. ${ }^{65}$ These are good starting points for arriving at a basic understanding of intangible assets but do not give deeper insights into the nature of intellectual property and its valuation and therefore do not need to be pursued for the purposes of this work.

60 Lev, Intangibles - Management, Measurement, and Reporting, p. 5.

61 See the list at Anson/Suchy, Fundamentals of Intellectual Property Valuation: A Primer for Identifying and Determining Value, p. 13/14, which is not exhaustive but a good starting point. It may well be that it is not even possible to establish an exhaustive list of intangible assets, because new forms of these assets are constantly being created. For example, a little more than decade ago, the existence and design of a company's website may not have been seen as an intangible asset. This is clearly different today, now that websites have become indispensable elements of marketing, production and distribution. This applies even more to marketing measures conveyed through podcasts and blogs.

62 Smith, Trademark Valuation, p. 4.

63 The reason being that the process of arriving at a value for a company's intangible assets by subtracting the value of all monetary and tangible assets from the market value of the company is systematically flawed. Whoever uses this method would make the value of the intangible assets of a company directly dependent on the market value of that company: if the share price fell, the intangible assets would at the same time have go down in value as well. Such a direct interdependence does, however, not exist.

64 Smith, Trademark Valuation, p. 4.

65 Lev, Intangibles - Management, Measurement, and Reporting, p. 18. 


\subsubsection{IP vs. Intangible Assets}

Since this work focuses on the valuation of intellectual property, the nature of IP as opposed to intangible assets, of which IP is a subset, needs to be clarified. For a proper understanding of IP value, it is indispensable to identify both this interrelationship and intangibles' value influencers, as they also have an impact on intellectual property value. ${ }^{66}$

Intellectual property comprises all those intangible assets which have been granted legal protection and recognition in a specific regime, i.e. which can be legally secured ${ }^{67}$ In contrast to other intangible assets, the list of intellectual property rights is relatively short. It comprises patents, utility models, trade marks, designs, copyrights and related rights, mask works, plant varieties and databases. ${ }^{68}{ }^{69}$ However, the fact that this asset group is rather small in number, compared to intangible assets, does not necessarily entail the consequence that it is small in value.

\subsubsection{Value Drivers and Detractors}

With regard to all assets, tangible and intangible, a thorough economic costbenefit analysis ${ }^{70}$ is central to the understanding of value. There are a number of value drivers and value detractors which have an effect on both the microeconomic and the macroeconomic level. However, their effects differ considerably with respect to tangible or intangible assets respectively. As will be seen shortly, a number of constraints and conditions when valuing IP assets can be quite different from those encountered in the course of tangible asset valuation.

66 This is the logical consequence of the fact that IP is a subset of intangibles.

67 Lev, Intangibles - Management, Measurement, and Reporting, p. 5.

68 Databases are at least protected through a separate regime in Europe, cf. Directive 96/9/EC of the European Parliament and of the Council of 11 March 1996 on the legal protection of databases, OJ L 77, March 27, 1996, pp. 20-28.

69 For the purposes of the Convention Establishing the World Intellectual Property Organization, Article 2 (viii) of said convention defines intellectual property as including the rights relating to "literary, artistic and scientific works, performances of performing artists, phonograms, and broadcasts, inventions in all fields of human endeavor, scientific discoveries, industrial designs, trademarks, service marks, and commercial names and designations, protection against unfair competition, and all other rights resulting from intellectual activity in the industrial, scientific, literary or artistic fields".

70 Note that cost, from a macroeconomic view as applied here, can be financial and non-financial. 
These factors are network effects, nonrivalry, scalability, nontradability, partial excludability, spillover effects and inherent risk. ${ }^{71}$ Understanding these issues is an essential part of comprehending both central value-related characteristics of intellectual assets and even the nature of intellectual assets as a whole. It is not only key to finding a systematic, comprehensive and applicable approach to valuation of intellectual property, but also to making intangible-related management and policy decisions.

Unlike the factors just mentioned, legal scarcity is not a macroeconomic factor influencing intangibles in general but the foundation of value potential of every IP right. However, since it belongs to the basic and indispensable value determining factors pertaining to all IP, it shall be included at the end of the above list.

\subsection{Network Effects}

A network effect is a phenomenon causing a good or service to have a benefit (or value) to a person, depending on the number of other persons consuming that good or service or on the number of enterprises offering it respectively. ${ }^{72}$ In other words, the more agents connected to the (physical or virtual) network the better.

For example, the more persons and enterprises are affiliated with the UMTS mobile telecommunication network, the more interaction and data exchange is possible and the more content and applications will be offered for that network. Such benefits, together with increasing interoperability, are positive consumption externalities, ${ }^{73}$ or positive network effects. ${ }^{74}$

The main reason for the development of such externalities is compatibility

71 For an extensive discussion of the economics of intangible assets cf. Lev, Intangibles Management, Measurement, and Reporting, Chapter Two.

72 Katz/Shapiro, 75 Am.Econ.Rev., iss.3, 424, 424 (1985). For an extensive, illuminating discussion of network effects, see Shapiro/Varian, Information Rules, p. 173 et seq.

73 An externality, or external effect, occurs when an agent, while making a decision, does not make allowance for the (monetary or non-monetary) costs or benefits caused for other stakeholders by that decision. In other words, the decision maker does not bear all of the costs or reap all of the benefits from his or her action (cf. Erlei/Leschke/Sauerland, Neue Institutionenökonomik, p. 272 et seq.). Translated to consumption externalities as mentioned above, this means that once a person decides to consume a certain good or service which makes himself part of a network, other network users benefit from that action because the size of the network increases.

74 Network effects are a specific type, i.e. a subgroup, of external effects. 
of all units the respective network comprises. Compatibility is facilitated by standards. For example, modern mobile telephony and telecommunication would be unimaginable without standardisation. ${ }^{75}$

The bigger the network becomes, the more interesting it is for non-members to become affiliated with it. Any prospective user makes his or her decision to become a member of a certain network with the expectation of success of the network. This positive expectation is crucial in network economies and increases the positive feedback effect of networks, which grows with the network. Hence, success begets success.

Network effects are not always positive, however. Effects which are positive for one group of agents may be negative for another. The so-called path dependency illustrates this: Once a network, for example of users of a specific pioneering software, has existed for some time, a new, improved software may have been developed by a rival company which tries to enter the market. However, since the older software is prevalent, the cost its users would have to bear in order to switch to the new software (acquisition, getting to know the new software, limited compatibility etc.) is in many cases too high to be outweighed by the benefits of change. Hence, even though all users of the old software still benefit from network effects, they are not able to benefit from the improved technology. Neither does the company selling the new software benefit from sales and market penetration, because the market barriers to entry are too high. These adversarial effects are also called negative network effects.

Network effects can be observed regarding both tangible and intangible assets. Yet increasingly innovations which were subsequently developed into a product or service and then secured by IP rights such as patents or trade marks lie at the core of important networks. ${ }^{76}$ Furthermore, network effects are considerably more prevalent with respect to industries which are mostly driven by intangible assets, such as the services sector and R\&D focussed industries, than with regard to physical-intensive industries. This is due to the fact that many industries needed and still need to adapt to changed conditions like globalisation by being less dependent on vertical integration

75 In Europe, for instance, the European Telecommunications Standards Institute (ETSI) has published the standards specifying GSM and UMTS, see http://webapp.etsi.org/ key/queryform.asp (last accessed October 12, 2006).

76 Lev, Intangibles - Management, Measurement, and Reporting, p. 29. A good example of such an intangible-focussed network is the network of all eBay users. 
but more dependent on networks of suppliers, customers and employees. ${ }^{77}$ Furthermore, intangible-related networks can usually grow much faster than networks of physical assets. The reason for this is that most intangible assets, or rather their physical carriers, can be copied and/or distributed easily, e.g. via internet. Take for example a software which can be downloaded online. Considerably more consumers can be reached at a time than for instance by a software dealer with brick-and-mortar premises.

This shows that an increasing number of consumers and industries have become users of or dependent on networks based on intangible assets. Positive network effects can be taken advantage of on a large scale and are therefore important value drivers of intangibles.

\subsection{Nonrivalry}

The nonrival nature of intangible assets is another value driver.

Physical (including human) and financial assets are rival. This means that a specific deployment precludes them from being used elsewhere simultaneously. For example, only one person can drive a specific car or work on a certain PC at a time. Such rivalry leads to positive opportunity $\operatorname{costs}^{78}$ for these rival assets. ${ }^{79}$

In contrast to that, an internet auction platform can, for instance, be used by a theoretically infinite number of persons at a time (this number merely being limited by factors such as internet connectivity and server capacity). This is due to the nonrival nature of intangible assets (here: the auction software, know-how etc.). As a consequence, opportunity cost, in general, does either not arise at all or is merely marginal in the case of intangible assets. The second person concluding a transaction via the on-line platform simultaneously to the first person causes only very little extra cost beyond the original investment. No opportunity is forgone - a thousand persons instead of one can be served at a time without diminishing the utility of the asset.

77 Cf. above at 2.1.1.1 and Lev, Intangibles - Management, Measurement, and Reporting, p. 31.

78 Opportunity costs are deficits accruing when an agent decides against an alternative use of an asset. The opportunity cost describes the utility the alternative deployment would have brought about, or - in other words - the benefit forgone, cf. Becker/Lutz, Gabler Kompakt-Lexikon modernes Rechnungswesen, p. 201.

79 Lev, Intangibles - Management, Measurement, and Reporting, p. 22. 
This shows why nonrivalry gives intangible assets a huge value potential.

The fact that intangibles are nonrival does not mean that they can be used by anyone at their free discretion, however. The nonrival character does not preclude legal protection. In fact, as will be set forth below, ${ }^{80}$ protection through various legal regimes is a central value enabling factor of IP rights.

\subsection{Scalability}

The fact that intangible assets can be deployed simultaneously in multiple uses is directly associated with the circumstance that they are - contrary to tangible assets - generally characterised by large fixed cost investments ${ }^{81}$ and little or negligible marginal cost. ${ }^{82}$ The R\&D costs for new drugs are usually a heavy million-Euro investment whereas the actual production cost of the pharmaceutical is comparatively negligible. Creating a new brand may be extremely costly, especially in the consumer goods industry, whereas attaching the corresponding sign to the respective items usually generates rather low cost.

The implication of this is that the utility of the research, ideas and inventions embedded for example in a new drug or brand can in theory be leveraged to create benefits in an unlimited way (basically, it is merely limited by market size). In other words, the scalability of intangible assets is usually considerably higher than of tangible assets. ${ }^{83}$ This is an important factor contributing to the value of intangible assets. Returns to scale ${ }^{84}$ are not as

$80 \quad$ At 2.1.1.3.7.

81 Fixed cost is a category of cost the size of which stays unaltered upon change of a certain cost influencing factor within a certain time period. It is accrued in constant size, independently of output, and merely capacity dependent and time proportionate, e.g. cost of acquisition of a machine or of R\&D, cf. Coenenberg, Kostenrechnung und Kostenanalyse, p. 35.

82 Lev, Intangibles - Management, Measurement, and Reporting, p. 22. Marginal (or incremental) cost is the sum by which the total cost rises in case the operating level rises one unit, i.e. the additional cost for the last produced unit, cf. Becker/Lutz, Gabler Kompakt-Lexikon modernes Rechnungswesen, p. 112.

83 Contrary to intangibles, tangible assets are generally characterised by diminishing returns to scale, i.e. an expansion in production does not result in an at least equivalent expansion of output. This may have reasons such as cost of resources and labour, employee fatigue etc.

84 This term denotes cost savings resulting from a certain production volume. Returns or economies of scale emerge in case the cost per unit for the production of a good sink with increasing output quantity, cf. Becker/Lutz, Gabler Kompakt-Lexikon modernes Rechnungswesen, pp. 70/71. 
quickly diminished as it is typical for tangible assets. They may even increase.

\subsection{Nontradability}

The economic characteristics of intangibles do not only have positive implications. Value detractors such as nontradability constitute the other side of the coin.

A trade mark owner, for example, may want to exploit the value of his asset by selling it. The fact that value of intellectual property assets, especially of trade marks (and therewith of brands), depends to a considerable extent on the identity of the proprietor constitutes a major stumbling block for such exploitation. The utility a brand entails and the revenue streams the proprietor is able to derive directly from it vary to a large extent depending on contextual issues such as whether the brand fits the proprietor company's strategies and asset portfolios. A pharmaceutical company, for example, wishing to assign a trade mark to a creditor as a debt security will be unlikely to succeed since in case of failure the creditor would have to sell the trade mark, having to find a buyer for whose trade mark portfolio the trade mark on sale would be a useful complement. Most companies, even many pharmaceutical companies, would not be interested buyers in such a situation.

Moreover, proprietors wishing to dispose of the brand will face considerable difficulties since, in general, no organised and transparent markets for trade marks and brands exist, ${ }^{85}$ in other words: trade marks and brands are generally not tradable, ${ }^{86}$ even though trade marks are alienable by law. Hence,

85 In principle, a market already exists wherever there is at least one single transaction, for example a licencing deal. The crucial difference between tangible and intangible assets is the absence of organised and transparent markets with respect to the latter, cf. Lev, Intangibles - Management, Measurement, and Reporting, p, 45. However, it must be noted in this connection that, in practice, no fully transparent markets exist. What is desirable is IP markets showing a degree of transparency sufficient for them to work.

86 This applies to all other intangible assets. With respect to some intellectual property rights, especially patents, there are and have been a few efforts to create markets, such as websites like Free Patent Auction - http://www.freepatentauction.com/, yet2.com - http://www.yet2.com/app/about/home, Idea Trade Network - http://www.newide atrade.com/ and MarkMarket (for trade marks) - http://www.ipb.dk/en/561/buysell \_trademarks/ and even blogs such as http://www.patentsale.blogspot.com/ (all last accessed October 16, 2006), as well as IP Marketplace newly introduced by the Danish Patent and Trademark Office, cf. http://www.ip-marketplace.org/ (last accessed October 11, 2008). These and other platforms have not yet shown the ability to reach a critical mass of proprietors in order to create a transparent market. However, 
they will have to use or create other channels such as one-on-one negotiations, which are likely to be considerably more time consuming and costly. Furthermore, there is either no or very little information about comparable transactions pricing information could be derived from. This means that other than market mechanisms need to be deployed in order to arrive at a price acceptable for both buyer and seller. ${ }^{87}$

This circumstance adds considerably to current uncertainty with respect to intellectual property valuation. To a substantial degree this is the case because it is widely perceived that a market price best reflects the value of an asset.

The fact that market prices for intangible assets cannot be obtained causes these assets to not be tradable. Less or no trade (which shall also include licencing, securitisation and other means of exploitation by transfer of ownership or use rights) means less or no value creation through exploitation of the asset and in consequence less value of the asset itself. Proprietors face immense difficulties of using the asset to its fullest potential. For example, a bank will - if at all - demand a higher interest rate, i.e. a risk premium, when lending money against an intangible asset security than when lending against plant and machinery - it is expecting the exploitation of the intangible asset in case of default to be considerably more difficult than the exploitation of a tangible asset (if not impossible). ${ }^{88}$ This causes illiquidity. In other words, such factual constraints result in ownership of intangible assets being conceptually worth less than ownership of tangible assets. The lack of organised and transparent intellectual asset markets means lack of valuable information for all parties to a transaction. Missing market price feedback impedes optimal resource allocation and management within the enterprise. In addition, it augments risk on the side of the buyer, licensee etc. of acquiring something unwanted, or to pay a so-called 'lemon's premium'. ${ }^{89}$

they mirror continuous efforts in order to build viable markets for intellectual property assets.

87 Another way of solving the problem of nontradability would be a future creation of markets, which - in case of intangibles - calls for methods alternative or new to tangible asset market creation. One prerequisite of this would be a systematic, comprehensive and generally accepted modus operandi of valuation.

88 This is the main reason why most banks still refuse to lend against intellectual property assets.

89 A lemon's premium is often demanded by one party to the transaction to make up for the risk inherent in the fact that not all information in order to make an informed decision can be gathered, that is, for existing asymmetry of information. It prevents this 
Proprietors of tangible (physical and financial) assets on the other hand can usually fall back on market mechanisms and information in order to trade and therefore exploit these assets.

\subsection{Partial Excludability and Spillovers}

With respect to tangible assets, the issue of control is clear, both legally and factually. Either the owner or the possessor exercises control of the object, for example a car. It is relatively easy to exclude unauthorised persons from using it (e.g. by locking the car), especially because the asset is tangible and can therefore be factually controlled.

As their designation suggests, this is not the case for intangible assets. Access to these assets is considerably more difficult to factually control. For example, an employee enjoying the benefits of employer-funded training will take all knowledge accumulated with him in case of a job change. Both the new employer and society at large will benefit. The debate relating to illegal digital music copying reflects such effects as well. Whether the intangible asset in question is legally protected or not, there is always a possibility of loss of factual control beyond what the proprietor has envisaged. Hence, intangibles are merely partially excludable; property rights in intangible assets are not fully secured. ${ }^{90}$ This gives rise to unwanted benefits to nonowners, so-called spillovers. ${ }^{91}$ Less control of the asset means less ability to exploit it as desired. Commonly, unauthorised persons cannot be fully excluded from savouring some of the benefits of the investment. The consequence is that, as a general rule, partial excludability is an intangible assets' value detractor. ${ }^{92}$

\subsection{Inherent Risk}

All corporate activity and all investment is risky. Yet as a general rule, investment in intangibles is substantially riskier than investment in tangible

party from opportunistic behaviour of the other, cf. Deutsche Bundesbank, Monetary policy and investment behaviour - an empirical study, p. 44 and Chen, Asymmetric Information, the Choice of Financial Distress Resolution and Implications for Corporate Debt Pricing, p. 5.

90 Hand/Lev, Intangible Assets. Values, Measures, and Risks, p. 2.

91 Lev, Intangibles - Management, Measurement, and Reporting, p. 33/34.

92 Note that this is seen from the proprietor's point of view. As just seen, there may be situations in which spillover effects are beneficial for society at large, making the asset more valuable from that point of view but not from the proprietor's. 
assets.

As seen above, investments in intangible assets are, contrary to investments in tangible assets, generally characterised by large fixed (sunk) costs during the initial phase of the project and little marginal cost at later stages. ${ }^{93}$ Little of the initial investment can be recouped in case the project turns out to be unsuccessful. This risk of total loss is also due to the general nontradability of intangibles and is very rare for financial or physical assets. In the case of bankruptcy, for example, it is rather unlikely that creditors would be compensated at all (and if so, it is highly improbable that they would be compensated sufficiently) through sale or other exploitation of the intangible asset. $^{94}$

Furthermore, a number of patent-related studies have proven the relatively high risk particularly associated with innovation-focussed intangibles. ${ }^{95}$ For instance, Scherer, Harhoff and Kukies have found that merely the top ten per cent of examined patents account for between 81 and $93 \%$ of total patent value. ${ }^{96}$ It follows that the majority of patents are valueless. Hence, return on investment is highly skewed. Similarly, a current German study has shown that almost half of all businesses pursuing a multi-brand strategy with on average eight brands in a portfolio realise $80 \%$ of their total turnover with solely three of their brands. In the case of almost $30 \%$ of all surveyed companies, the strongest brand alone generates more than $60 \%$ of total turnover. ${ }^{97}$

Not only does this pose unique challenges to management; it also entails substantial ramifications with respect to the financing and investment communities. As a direct consequence of the risk inherent in intangible assets, financiers such as venture capitalists demand relatively high risk premia. Managers need to create joint ventures, engage in R\&D outsourcing and alliances and diversification of asset portfolios in order to mitigate the risk inherent in intangibles.

It is important to realise that, in general, the level of overall risk concerning

93 Above at 2.1.1.3.3.

94 Cf. below at 2.3.2.3.

95 Schankerman/Pakes, 96 Econ. J., 1052 (Dec. 1986); Scherer/Harhoff/Kukies, 10 Journal of Evolutionary Economics, 175 (2000); Harhoff/Scherer/Vopel, Exploring the tail of patented invention value distributions.

96 Scherer/Harhoff/Kukies, 10 Journal of Evolutionary Economics, 175 (2000).

97 MP Marketing Partner AG, Studie: Rentabilität von Marken oft fraglich - Unternehmen im Zugzwang. 
future return on investment continually decreases along the value chain. The intensity of use of intellectual assets is highest at the beginning, for example at basic research or brand innovation stage. This phase entails the highest risk regarding technological and commercial success. ${ }^{98}$ Less and less intangibles need to be deployed in subsequent value chain stages such as product development, manufacturing and marketing. ${ }^{99}$ These phases increasingly involve tangible assets and are therefore less exposed to risk.

\subsection{Legal Scarcity}

Intangible assets are by definition free. Since they cannot be physically controlled and are based on ideas and abstract concepts, they can in theory be simultaneously used by an infinite number of persons. ${ }^{100}$ For example, a sign could be used by anyone at any time if it was not for the trade mark owners' rights to control its use. Similarly, the same invention could be used by competitors in trade or commerce if there was no legal protection - subject to the condition that the proprietor has not chosen to keep the invention a business secret.

As a general rule of supply and demand, if something is available freely everywhere, it has no or at best minimal value. If something is scarce, however, it generally becomes valuable due to comparatively increased demand. ${ }^{101}$

Unlike physical assets, intangibles are not characterised by factual scarcity. Apart from secrecy, it is only the various legal protection regimes which make these assets scarce. ${ }^{102}$ Only the granting of intellectual property rights ${ }^{103}$ makes sure that a controlled number of persons are allowed to use the re-

98 Lev, Intangibles - Management, Measurement, and Reporting, p. 40.

99 Flignor/Orozco, Intangible Asset \& Intellectual Property Valuation: A Multidisciplinary Perspective, p. 8.

100 This is due to their partial excludability and spillover effects, see above, 2.1.1.3.5.

101 Cf. above at 1.3.1.

102 The option of keeping an intellectual achievement secret is being used in practice with respect to technical inventions yet is not applicable to all types of intellectual assets. For example, a brand can by definition not be kept secret since its intrinsic and main function is to constitute a means of communication between proprietor and target audience.

103 Apart from intellectual property law, there are other legal frameworks which are applicable to intangible assets, such as labour law (with respect to human resources) or competition law. However, these regimes do not provide for legal scarcity as they do not particularly regulate proprietors' private rights to grant access to the respective assets in terms of a property right. 
spective intellectual achievement. This legal protection is what gives certain intangibles a potential to develop a value.

To sum up, one can say that IP rights (and not intangible assets, to which the respective property rights do not apply) have an intrinsic potential to be valuable, caused by their legal scarcity.

\subsubsection{Intermediate Findings}

Due to a changed global business environment in developed economies and increased utilisation and awareness of intangible assets, these assets have come to play a major role in today's corporate world. They are claims to future benefits without a physical or financial embodiment and therefore entail specific characteristics different to those of tangible assets. These include amongst others - nonrivalry, nontradability and inherent risk and can considerably affect the respective asset's value, positively or negatively.

For a comprehensive intellectual property valuation tool it is decisive to operationalise these characteristics, as intellectual property comprises all those intangible assets which are legally protected through a specific regime and is therefore part of the group of intangible assets.

Furthermore, partial excludability and spillovers, which are value detractors, can be mitigated to a considerable extent by intellectual property regimes which provide for legal scarcity (unless secrecy has been chosen). Therefore, legal protection ensures the potential of intellectual property rights to become valuable as assets.

\subsubsection{The Term 'Trade Mark' as Opposed to 'Brand'}

The importance of certain intangible and intellectual property assets varies by industry sector. In the non-generics pharmaceutical industry, for example, patents constitute the central source of value creation. ${ }^{104}$ For companies in the luxury goods and fast moving consumer goods (FMCG) industries, for

104 However, trade marks play an important complementing role for purposes of marketing the respective patented product. They even are of critical importance during the final phase of patent protection and beyond as manufacturers of generic products prepare and put into action their market entry during these periods. 
instance, brands make up a substantial portion of overall value and may well represent their most important IP assets. ${ }^{105}$

This prominent role of brands is to be ascribed to the fact that they influence enterprise value as a central determinant. Against the background of globalisation, rising intensity of competition, increased product quality similitude and information overload, ${ }^{106}$ brands today are more than ever crucial due to their ability to create a psychological connection and a communication channel between the brand (and thereby the originator) and the audience. This contributes considerably to successful product or service marketing and even to other stages in the value chain such as research and production ${ }^{107}$ and therefore to the success and survival of the company as a whole.

In order to be able to identify, manage and control this brand-intrinsic potential of successfully generating revenue and profit, the respective brand needs to be comprehensively valued or evaluated respectively as part of an overall holistic brand management strategy. Every such (e)valuation necessarily presupposes a thorough understanding of its object, in other words, the 'what' of valuation. One can only value something which has been clearly defined. It is therefore essential to clarify the nature of the IP right trade mark, of the intangible asset brand and to illuminate how these assets are interrelated.

\subsubsection{Trade Marks - Definition and Functions}

\subsection{Trade Marks as Legal Phenomena}

A trade mark is a legal construct which can be defined as any sign or combination of signs, provided that such signs are capable of distinguishing the goods or services of one undertaking from those of another. ${ }^{108}$ A trade mark

105 Haigh, Brands in the boardroom (2004), p. 19.

106 Cf. fn. 242.

107 The reason being that e.g. external suppliers are subject to less risk of failure of the transaction in case of dealing with a strongly branded business than in situations in which their customer is a business with no or weak brands. Similarly, a brand which is well communicated and lived internally contributes substantially to value creation by all internal stakeholders. This will be explained in more detail below at 2.1.2.2.

108 In dependence on Art. 4 Council Regulation (EC) No 40/94 of 20 December 1993 on the Community trade mark, OJ L 011, January 14, 1994, p. 1 (hereinafter: CTMR), Art. 2 First Council Directive 89/104/EEC of 21 December 1988 to approximate the laws of the Member States relating to trade marks, OJ L 040, February 11, 1989, p. 1 (hereinafter: CTMD) and Art. 15 (1) TRIPs (Agreement on Trade-Related Aspects of Intellectual Property Rights). 
is the only government-granted exclusive right which is renewable in perpetuity. 109110

Even though merchants have distinguished their goods from those of their competitors by marking them with a unique symbol or device since very early times, ${ }^{111}$ it is not until relatively recent years that trade marks are recognised as subjective exclusive rights which form part of the proprietor's property. Even trade mark applications are regarded as property rights, as they give rise to a set of proprietary rights such as entitlement to expect that the application will be examined subject to satisfaction of procedural and substantive requirements. ${ }^{112}$

In the early days of trade mark protection, there existed no body of law specifically focussed on trade marks. As trade marks were seen as the central symbolic representation of commercial reputation, trade mark law was, for example in common law countries, developed based on the tort of passing off, which is an action used against the abuse of another's commercial reputation. ${ }^{113}$

As of today, however, there are a number of different national and international legal regimes which particularly govern trade marks. ${ }^{114}$ A multitude

109 A service mark relates to services only, as the name implies. Since there are no legal differences between trade and service marks, the discussion will hereafter only mention trade marks as a synonym for trade and service marks.

110 There are special subcategories of trade marks such as collective marks (cf. Art. $7^{\text {bis }}$ (1) Paris Convention, Art. 1 CTMD, Artt. 64 et seq. CTMR and $\S \S 97$ et seq. German Tademark Act) and certification marks. A collective mark is protected in the name of an association of business enterprises which are all entitled to use the mark in connection with their products or services supplied. A certification mark serves to distinguish goods or services which are certified from those which are not. A producer can for example have his goods certified in terms of quality, origin or material. However, this producer does not own the certification mark - that mark is usually owned by third party agencies which monitor certain quality standards and approve goods or services to comply with these standards by allowing the marking of the relevant product or service with the certification mark. An example for a certification mark is the $V D E$ sign issued by the German VDE (Verband der Elektrotechnik Elektronik Informationstechnik e.V. - Association for Electrical, Electronic \& Information Technologies) Testing and Certification Institute. Since collective marks and certification marks are both categories of trade marks, they will not be mentioned separately hereafter.

111 Fezer, GRUR 2003, 457, 458/459.

112 European Court of Human Rights (ECHR) [GC], judgment of January 11, 2007, Case 73049/01, Anheuser-Busch Inc. v Portugal - Budweiser, para.s 75 and 78.

113 IPR Helpdesk, Trade Mark Agents Manual, p. 4; Morcom/Roughton/Graham, The Modern Law of Trade Marks, p. 5.

114 Yet trade mark law can still be seen as part of the wider concept of protection against unfair competition, cf. for many Kane, Trademark Law - A Practitioner's Guide, § 
of countries throughout the world have enacted national trade mark laws. As these laws may differ considerably yet trade marks often aim at an international audience and therefore need an internationally uniform system of protection, there are several supranational and international trade mark law and registration ${ }^{115}$ regimes, offering a certain degree of minimum standards and harmonisation in the field. The most important ones are the Paris Convention, ${ }^{116}$ the TRIPs agreement, ${ }^{117}$ the Trademark Law Treaty, ${ }^{118}$ the Madrid Agreement and the related Protocol, ${ }^{119}$ the European Community Trade Mark Directive ${ }^{120}$ and the European Community Trade Mark Regulation. ${ }^{121}$ Details of trade mark law will be dealt with in chapter five. For the purposes of this part of the study, it is important to recognise the nature and characteristics of trade marks and their legal protection framework.

\subsection{Trade Mark Types}

A trade mark can take a variety of forms, such as word, picture, combination (word-picture), three-dimensional form, sound, or smell. Even though the legal definition of trade mark has generally been unaltered in recent years, the nature of trade marks is constantly evolving and changing as the scope of protection gradually broadens. Traditionally, a trade mark has always been a visual representation. Today, there are a number of sounds and other non-traditional signs registered as trade marks. ${ }^{122}$ With global

\section{$1: 1.5$.}

115 Registration is not necessarily a conditio sine qua non for trade mark protection. Details will be given in chapter five.

116 Paris Convention for the Protection of Industrial Property of March 20, 1883, as revised and amended. As of January 15, 2008, there were 172 Member States to the Convention.

117 Cf above, fn. 108.

118 Trademark Law Treaty (TLT), done at Geneva on October 27, 1994. As of January 22, 2008, there were 40 Contracting Parties, including Germany. On March 27, 2006, 147 WIPO Member States adopted the Singapore Treaty on the Law of Trademarks (Singapore TLT), the result of four years of work on revision of the TLT.

119 Madrid Agreement Concerning the International Registration of Marks of 1891, as revised and amended and the Protocol Relating to the Madrid Agreement Concerning the International Registration of Marks of 1989.

120 Cf. fn. 108.

121 Ibid.

122 More on this below at 5.2.3 and 5.2.5. The jingle of Deutsche Telekom AG may serve as an example of a sound mark at this point. It has been registered with the German Patent and Trade Mark Office under the number 39940591.7 since 1999 and is also registered in other countries, e.g. Australia (no. 818174, since 2004). 
media and advertising landscapes evolving as they do, it is not surprising that we nowadays encounter holograms and 'moving' pictures as trade marks. ${ }^{123}$ itextarea ijtextareaij/textareaij/textareai,

\subsection{Trade Mark Functions}

Trade mark functions affect both single persons, proprietor entities and society at large. Like all other intellectual property, trade marks are rights of exclusivity granted in public interest. ${ }^{124}$ The quid pro quo trade mark proprietors are giving in return for this support is signalling product origin and hereby differentiation, which increases and facilitates consumers' choices.

The denotation of the trade source, or origin, of the respective goods or services is not the sole but the core function. ${ }^{125}$ It is central to any legal definition of a trade mark as set forth above ("... capable of distinguishing the goods or services of one undertaking from those of another."). The origin function runs like a central theme through important points of assessment of registrability and trade mark infringement. It is essential for the examination not merely of distinctiveness and infringing trade mark use but also of whether a trade mark is being duly used by the proprietor. ${ }^{126}$

As Merriam-Webster OnLine defines, a trade mark is "a device [...] pointing distinctly to the origin or ownership of merchandise to which it is applied and legally reserved to the exclusive use of the owner as maker or seller". ${ }^{127}$

123 Cf. e.g. CTM no. 255914434, registered since 2004, consisting of holographic paper for use as packaging surface, and the German mark no. 30157686.6, consisting of a set of six pictures to be animated, registered since 2002. The latter mark is, however, registered as a simple figurative mark.

124 This is widely recognised with respect to patents yet there seems to be no logical reason to negate this in the case of trade marks, cf. Greenhalgh/Rogers, Trade Marks and Market Value in UK Firms, p. 3.

125 Cf. Recital 10 CTMD. Furthermore, this is settled ECJ case law, cf. e.g. judgment of 29 September 1998, Case C-39/97, [1998] ECR I-5507, Canon Kabushiki Kaisha v MetroGoldwyn-Mayer Inc. - CANON, para. 15; judgment of 18 June 2002, Case C-299/99, [2002] ECR I-5475, Koninklijke Philips Electronics NV v Remington Consumer Products Ltd - Philips, para.s 29-34; judgment of 21 October 2004, Case C-64/02 P, [2004] ECR I-10031, Office for Harmonisation in the Internal Market (Trade Marks and Designs) v Erpo Möbelwerk GmbH - DAS PRINZIP DER BEQUEMLICHKEIT, para. 33. German case law has developed its argumentation along the same lines, cf. e.g. BGH, judgment of 2 November 2000, Case I ZB 28/98 - Montres; judgment of 19 September 2001, Case I ZB 6/99 - grün eingefärbte Prozessorengehäuse.

126 Ströbele/Hacker, Markengesetz, $\S 14$ no. 58 and $\S 26$ no. 3.

127 Merriam-Webster Online Dictionary, entry for 'trade mark'; http://www.m-w.com/ cgi-bin/dictionary/trademark (last accessed June 20, 2007). 
Hence, the origin function is not only core to the understanding of the term trade mark by the legal profession but also by (the English-speaking, that is) society at large.

Source identification means that the addressee of the respective sign knows that there is a certain trade source the information a trade mark conveys can be associated with. However, it is not necessary that consumers are aware of the specific identity of the source. It is not essential that the trade mark belongs to the manufacturer of the marked product. Rather, the origin function in its modern interpretation refers to the entity which takes responsibility for the marked product or service. ${ }^{128}$ The product origin may be a merchant whose goods are specifically manufactured for the trade mark owner. ${ }^{129}$

By designating a commercial source, trade marks necessarily distinguish the goods or services they relate to from goods or services of different commercial origin. Hence, this function of differentiation is closely related to and a direct consequence of the origin function. This can already be recognised considering the legal definition of a trade mark as described above. The importance of the differentiation function, essentially linked to the origin function, is reflected in the fact that it too plays a vital role in the course of assessment of distinctiveness of a mark. ${ }^{130}$

As well as the issues how exactly a trade mark can and should be marked off against a brand, the matter of trade mark functions is, in detail, controversial. In addition to the origin and differentiation functions, other - economic functions are often allocated to trade marks as well. ${ }^{131}$ This can be, to a considerable extent, ascribed to the circumstance that what constitutes a trade mark and a brand respectively is often not clearly enough defined. Furthermore, the concepts of brand and trade mark are sometimes not kept apart at all, even though - as will be explained shortly - they are constructs which differ significantly despite the fact that they overlap to some degree.

128 Hence, the ECJ has defined the origin which a trade mark is supposed to guarantee as the place from which the manufacturing is controlled (i.e. not necessarily carried out), cf. e.g. judgment of 22 June 1994, Case C-9/93, [1994] ECR I-2789, Internationale Heiztechnik GmbH v. Ideal Standard GmbH - Ideal Standard II.

129 For instance, the German retailer Aldi sells certain fast moving consumer goods under the trade mark and brand CIEN, which are produced by a company which also manufactures for other brands. Brands such as CIEN are called 'private labels' or 'store brands', or in German 'Handelsmarken', and will be further introduced infra at 2.1.2.2.2.

130 See below at 5.2.3.

131 Cf. e.g. Ströbele/Hacker, Markengesetz, § 8 no. 39. 
In view of the fact that a trade mark is a legal concept as described above, trade mark functions should, accordingly, be restricted to those which relate to these legal aspects. In consequence, economic functions such as advertising, warranty and risk reduction functions rather denote characteristics relating to a concept going beyond the legal realm of trade marks. Contrary to the origin and product or service differentiation functions, they are of no importance for purposes of due registration of a trade mark ${ }^{132}$ and other trade mark law issues. By contrast, they allude to aspects which are characteristic for the brand as a whole, especially as a marketing means, and will therefore be dealt with in the following.

In this light, what Kapferer means by saying that the legal approach or definition of a brand is "most useful for defending the company against copies of its products" but "should not become the basis of brand management" 133 is in essence that the legal definition, which in fact refers to the trade mark, is not able to capture all those elements of a brand which go beyond the trade mark itself. ${ }^{134}$

It follows from the aforementioned that, considering the legal nature of trade marks, trade marks and their functions can be relatively clearly defined. ${ }^{135}$

However, even though the concept of trade mark is purely legal and as such self-contained, a trade mark never travels alone in a vacuum. It is, provided that it is not merely registered but also put to use, always accompanied by marketing components combined with which it constitutes a brand. Hence, a trade mark is a brand inasmuch as it is protected by trade mark law. In other words, a brand consists of at least one trade mark as well as other elements

132 BGH, judgment of 13 November 1997, Case I ZB 22/95 - GARIBALDI. Functions other than source identification and differentiation do not belong to the legally specified nature of trade marks but describe possible uses of such marks for marketing purposes, cf. Sambuc, WRP 2000, 985, 988.

133 Kapferer, The new strategic brand management: creating and sustaining brand equity long term, p. 11.

134 This citation also shows that a number of writers, most of whom are no legal experts, do not use terminology distinguishing trade marks and brands but rather refer to a trade mark as the legal definition of brand. This is per se not wrong, especially from a practical brand management point of view. However, since trade marks do exist within a self-contained legal concept which raises the issue of how their relationship to brands shall be defined, this work has taken a different approach.

135 The distinction of trade marks and brands would probably be easier for Germanspeaking persons if it was not for the fact that both are called 'Marken'. In practice, a number of German-speaking persons have therefore started utilising the term 'brand' for clarity purposes. Conversely, this does not mean that the distinction between the two terms is clear and undisputed in the English-speaking area. 
which are not protectable as trade marks.

As a consequence, trade mark law - as protecting the so-called brand device $^{136}$ - is, de jure, neither able to fully capture all brand characteristics and issues nor suitable for doing so. ${ }^{137}$ This trade mark-brand dichotomy also means that a trade mark has to be seen, managed and valued, in terms of forecasting valuation, in the context of all factors and signals accompanying it. One would ignore crucial elements if the focus of valuation was merely on the trade mark but not on the brand as a whole. This is why this study focuses on and speaks of brand and not merely of trade mark (e)valuation. ${ }^{138}$

\subsubsection{Brands - Definition and Functions}

Compared to trade marks, brands are more complex and multifaceted phenomena. Therefore, they are more difficult to describe and define. There is no universally recognised definition of 'brand'. ${ }^{139}$ Although it is accepted that

a brand is more than merely one or several signs which may be trademarkable, ${ }^{140}$ it has been and remains disputed in what respect and with which

136 Brand devices, also called brand icons, denote the signage of a brand such as name, logo, brand specific melodies (i.e. 'jingles') and others, cf. Burmann/Blinda/Nitschke, Konzeptionelle Grundlagen des identitätsbasierten Markenmanagements, p. 43.

137 However, even though trade mark law de jure only protects the trade mark or, in other words, the device, it de facto aims at protecting the whole brand itself (this is to some extent done by complementary areas such as competition law, antitrust law and trade name law). The fact that only those functions which have a direct link to the legal definition of trade mark should be recognised as trade mark functions does not mean that functions going beyond, or economic ones, are insignificant for legal trade mark issues. They do not have direct but indirect bearing (similarly Vanzetti, GRUR Ausl. 1965, 128, 129.). For example, an attorney trying to protect his client's trade mark against a potentially confusing other mark will always do this in view of protecting the whole commercial appearance and all involved financial interests of the client. Since there is no 'brand law', he has to resort to the instrument of trade mark and e.g. unfair competition law.

138 Smith, for example, deals with the trade mark-brand dichotomy by assuming that "a trademark carries with it the other elements ascribed to a brand" without exactly saying what these elements are but giving a few examples (Smith, Trademark Valuation, p. 44). However, in the subsequent sentence, he warns the reader that this is not always the case. This study, in order to prevent having to work with more fictions than necessary, aims at denoting the difference between a trade mark and a brand more clearly. This will particularly benefit the analysis of value creating factors to a brand.

139 Cf. e.g. Günther/Kriegbaum-Kling, Schmalenbach Business Review 2001, 263, 268.

140 Cf. e.g. Aaker, Building strong brands, p. 25; Esch/Wicke/Rempel, Herausforderungen und Aufgaben des Markenmanagements, p. 10; Gaiser, Brennpunkt Markenführung - Aufgabenbereiche und aktuelle Problemfelder der Markenführung, pp.8-10; Günther/Kriegbaum-Kling, Schmalenbach Business Review 2001, 263, 270; 
implications a brand goes beyond the legal concept of a trade mark. In fact, the definition of 'brand' is, as Kapferer puts it, "one of the hottest points of disagreement between experts". ${ }^{141}$ This uncertainty and lack of clarity with respect to the term 'brand' have been in existence since the beginning of systematic debate about brands and their management. They are not only based on the intrinsic complexity of brands themselves. Also, they are attributed to both the different scientific backgrounds of involved scholars as well as practitioners and developments which took place over time, ${ }^{142}$ leading to a changed perception of brands. ${ }^{143}$

What seems to have won recognition by now is the finding that the intellectual property right (whether it is referred to as 'trade mark' or as something like 'legal definition of brand'), the marked product and the brand are three distinct matters. ${ }^{144}$

\subsection{Brands as Personality-like Phenomena}

The term 'brand' has experienced numerous developments and changes since the beginning of its systematic scientific scrutiny. According to the 'classical', formally oriented approach, a brand is understood as merely a physical sign of origin of a branded finished product. ${ }^{145}$

Homburg/Krohmer, Grundlagen des Marketingmanagements. Einführung in Strategie, Instrumente, Umsetzung und Unternehmensführung, p. 181 and Kapferer, The new strategic brand management: creating and sustaining brand equity long term, $\mathrm{p}$. 11.

141 Kapferer, The new strategic brand management: creating and sustaining brand equity long term, p. 9.

142 Regarding the modern era, one can distinguish five phases during which the understanding of brands developed in line with profound factual changes and gradually broadened. They range from industrialisation and mass production (mid-19th century until the beginning of the 20th century), when brands were merely perceived as owner's signs and proof of origin, to the information society (1990s until today), with a much broader and diverse perception of brands prevailing. For a comprehensive overview of these historical developments and their implications on brands and brand management, cf. Meffert/Burmann, Wandel in der Markenführung - vom instrumentellen zum identitätsorientierten Markenverständnis. Similarly Bamert, Markenwert, p. 32 et seq.

143 Baumgarth, Markenpolitik. Markenwirkungen - Markenführung - Markencontrolling, p. 2.

144 Cf. e.g. Burmann/Meffert/Koers, Stellenwert und Gegenstand des Markenmanagements, p. 5 .

145 Mellerowicz, Markenartikel - Die ökonomischen Gesetze ihrer Preisbildung und Preisbindung, pp. 39/40 and Esch/Wicke/Rempel, Herausforderungen und Aufgaben des Markenmanagements, p. 9. The complete Mellerowicz definition of 'branded articles', 
Kotler's definition seems to follow a similar track by specifying a brand as "a name, term, sign, symbol, or design, or combination of them, which is intended to identify the goods and services of one seller or a group of sellers and to differentiate them from those of competitors". ${ }^{146}$ After all, he does not limit brands to being markers of finished consumer products, as the previous definition does. Such limitation is not appropriate nowadays as brands are also used for services, industrial goods and components ${ }^{147}$ of finished products.

Both definitions, however, focus on the formal appearance of brands, the so-called devices or symbolic utility components (words, symbols etc.; those elements which can possibly be protected as one or several trade marks). By specifically mentioning the origin and differentiation functions, Kotler is even closely approximated to the legal definition of trade mark as introduced above. ${ }^{148}$

These formally oriented definitions are not wrong in their entirety since the device is a constitutive characteristic of a brand, essential for purposes of identification, differentiation and indication of origin. However, in line with what has been stated above with respect to trade marks, ${ }^{149}$ understanding a brand as consisting of solely one or several marks or signs (with origin and differentiation function) does not do justice to the phenomenon brand. Looking at the implications brands have on internal and external audiences, it becomes evident that such approach is too narrow. ${ }^{150}$

Brands are developed to create long-term influence on buyer behaviour in favour of the marked products or services. Such behaviour cannot merely be influenced and explained by means of formal, symbolic elements and the origin and differentiation functions of brands. Rather, in analogy to the fact that

translated into English, is "ready-made goods for private use which are available in a greater sales area under a specific token (brand), in uniform appearance, amount and in constant or improved quality, and which have, thereby and by advertising, acquired acceptance of the respective business communities (consumers, dealers and producers)".

146 Kotler, Marketing management: analysis, planning, and control, p. 482.

147 Brands used with respect to such components are called ingredient brands. INTEL INSIDE (PC processor units) and SHIMANo (bicycle components) are two well-known examples.

148 At 2.1.2.1.1.

149 At 2.1.2.1.3.

150 Esch/Wicke/Rempel, Herausforderungen und Aufgaben des Markenmanagements, p. 10; Gaiser, Brennpunkt Markenführung - Aufgabenbereiche und aktuelle Problemfelder der Markenführung, p. 8. 
a person is only perceived by others as a differentiated personality if its name and appearance evoke concrete ideas and associations, a set of signs does not become a brand until it causes associations regarding, amongst others, product characteristics, possible uses and certain emotional experiences. ${ }^{151}$

Hardly any consumers would, for example, buy the energy drink RED BuLL because it is manufactured in Austria or the manufacturing is controlled by a specific Austrian company. Rather, the central influencing factors are that it is perceived as young, hip and 'giving you wings'. ${ }^{152} 153$ A strong premium automotive brand such as BMW does benefit from its German origin as such origin is widely associated with quality products. However, the brand evokes many other associations in consumers' minds such as 'safe and reliable', 'expensive', 'Freude am Fahren'154 and 'fast'. ${ }^{155}$ This results in the German origin being one influencing factor of many and - in case of a brand as strong as BMW - not the most influential one.

These examples clarify that an effect-oriented view, instead of a formal one, is an essential step towards full understanding of the nature of brands and their influence. A brand is not merely a name or a symbol but a construct which is, at least to a considerable part, generated in the mind of the consumer. The existence of formal markings or devices, which can possibly be protected as trade marks, are a necessary but not a sufficient condition for the formation of a brand. The respective signs do not become a brand until they evoke and leave behind certain associations in customers' minds.

The entirety of all such associations, leading to a certain perception of the respective brand within the audience, is referred to as brand image. As humans are perceived in certain ways by others, so are brands. This is what they are designed and positioned for. Brand image can therefore be defined as "perceptions about a brand as reflected by the brand associations held in the consumer memory". ${ }^{156}$

Brand image steers buyer behaviour. Basic prerequisite for the formation of a

151 Gaiser, Brennpunkt Markenführung - Aufgabenbereiche und aktuelle Problemfelder der Markenführung, p. 9.

152 The slogan, or claim, is "Red Bull verleiht Flüü̈gel" - 'Red Bull gives you wiiings'.

153 Similarly Esch/Wicke/Rempel, Herausforderungen und Aufgaben des Markenmanagements, p. 10.

154 In English: 'The fun of driving'.

155 Franzen/Fuchs/Paninka, Psychologie der Marken, p. 2.

156 Keller, 57 Journal of Marketing, issue 1, 1, 3 (1993). 
brand image (and therefore no part of brand image itself) is brand awareness. It measures the strength of the brand trace in memory, as reflected by the ability of potential consumers to remember a brand device (brand recall) or to recognise it after acoustic and/or visual aid (brand recognition), and to attribute these perceptions to a product category. ${ }^{157}$ Brand awareness is a necessary precondition for development of a brand image in the mind of the consumer, which influences buyer behaviour and thereby turnover and income generated by the brand. Understanding brand awareness and image, which together constitute brand knowledge, is therefore crucial for valuation purposes.

To facilitate insight, the components of brand image can be divided into three parts: brand attributes, the functional and the symbolic benefits of the brand..$^{158}$

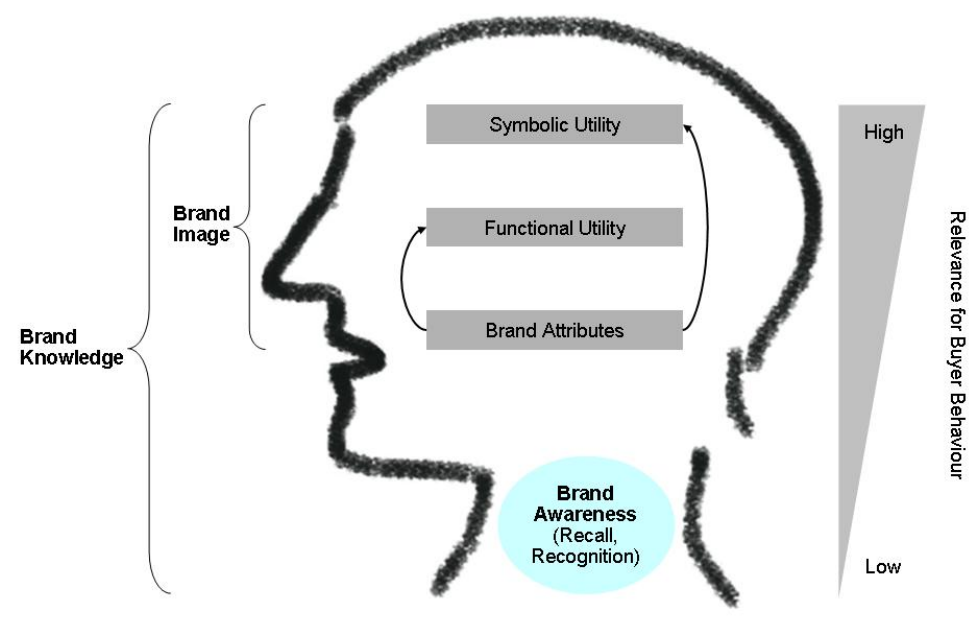

Figure 2.1: Brand image (source: author's own on the basis of Burmann/Blinda/Nitschke, Konzeptionelle Grundlagen des identitätsbasierten Markenmanagements, p. 7).

Brand attributes are all characteristics of a brand the respective consumer is aware of, for example form and smell of the marked product or its country of origin. Every member of the brand audience consciously and unconsciously

157 Burmann/Meffert, Theoretisches Grundkonzept der identitätsorientierten Markenführung, pp. 53-54 and Keller, 57 Journal of Marketing, issue 1, 1, 3 (1993).

158 Burmann/Meffert, Theoretisches Grundkonzept der identitätsorientierten Markenführung, p. 54 . 
condenses and assesses the entirety of all brand attributes. The outcome of this process is the functional and symbolic ${ }^{159}$ utility the respective consumer perceives the brand to have. Brand awareness is said to have the least influence on actual buyer behaviour whereas the symbolic utilities are, of brand awareness and all components of brand image, generally the most influential factors. ${ }^{160}$

A certain brand only influences buyer behaviour in a positive way if customers, based on associations and on experiences with the brand itself and with other members of society who are also connected to the brand, perceive it as bringing about added value for them. ${ }^{161}$ Such added value, or added benefit, may for example result from product quality and attribute information or social affiliation with a group of status symbol owners conveyed by the brand. This perceived added benefit represents brand value as seen from the buyer's point of view, in other words, the psychographic brand value. ${ }^{162}$

The expediency of the approach to brands as complex personality-like constructs results from the fact that brands substitute direct personal relationships. Apart from antiquity when simple marks on handcrafted items were already utilised as owner's signs ${ }^{163}$ and from cattle farming and other animal husbandry, where they served and still serve the same purpose, brands gained considerable momentum during early industrialisation in the mid19th century. Mass production of many goods handcrafted to date lead to loss of the personal relationship between producer and end user. ${ }^{164}$ In many sectors, anonymous (i.e. unbranded) products on mass markets dominated

159 Aaker distinguishes functional, emotional and self-expressive benefits, which means he subdivides the symbolic utilities for an even finer distinction, cf. Aaker, Building strong brands, p. 79 .

160 Burmann/Meffert, Theoretisches Grundkonzept der identitätsorientierten Markenführung, pp. 54-55. Functional utility comprises all those perceived benefits which result from functional physical characteristics of the branded products (e.g. the taste of a chocolate bar) and from information, confidence and risk reduction functions of the brand (e.g. making the customer trust in product safety or sufficient spare part supply). With both quality and 'look and feel' of products and services in many sectors becoming increasingly alike, the additional, symbolic, utility brands can bring about, such as symbolising certain values and lifestyles (e.g. the so-called 'LOHAS', who live a lifestyle of health and sustainability), has become increasingly decisive in many sectors.

161 Burmann/Meffert/Koers, Stellenwert und Gegenstand des Markenmanagements, p. 9.

162 Farquhar, 30 Journal of Advertising Research, iss. 4, RC-7, RC-8 (1990). More on psychographic brand value and its measurement at 3.2.3.

163 Fezer, GRUR 2003, 457, 457.

164 Leitherer, Markenartikel 1955, 539. 
the scene. It was not until the early 1900s that increasing price competition caused widespread use of brands. This development sparked the ongoing phenomenon that brands act as substitutes of persons or personal relationships respectively. ${ }^{165}$ Thereby, they indirectly allow the proprietor to come into contact with the end consumer again.

By functionally substituting living persons, brands consequentially need to show certain features, similar to those of persons, which are necessary to perform this role. These do not only include an image but, as a logical consequence, also an identity. Brand image does not emerge of its own volition. It is always caused and shaped by interaction between the respective recipient and expressions of brand identity. An existing identity is a necessary precondition for it being reflected by associations forming an image.

For humans, identity is the core factor of authenticity and effective differentiation from others. This applies similarly to brands, ${ }^{166}$ as they substitute humans with regard to certain functions, as just described. In analogy, brand identity is, therefore, the self-perception of the brand as seen by the internal target groups (employees, management etc.) within the proprietor institution. ${ }^{167}$ It can be defined as those attributes of a brand which effectively shape the character of the brand from the viewpoint of internal target audiences. ${ }^{168}$

Its constitutive components can be identified as brand origin, core compe-

165 Similarly, from an informational economics point of view, some scholars denote brands as "information surrogates", cf. Baumgarth, Markenpolitik. Markenwirkungen - Markenführung - Markencontrolling, p. 25.

166 This is not without controversy. It is undisputed today that brands show more features than merely those necessary in order to serve as owner's signs and proof of origin. However, opinions diverge with respect to the quality of brand characteristics and functions going beyond such outdated understanding. Especially in the light of the reason why brands were put in place just explained, it is convincing to see brands as a complex system of communication with an internal view, or brand identity, and an outsider's perception, the so-called brand image. Furthermore, according to Gilmore's theory of animism, humans generally tend to animate artefacts by awarding them human characteristics (Gilmore, Animism). In this light, brands do show human traits such as an identity. In addition, social science research has plausibly demonstrated that companies and brands as groups of persons consequentially show identity in the form of corporate and brand identity (Burmann/Meffert, Theoretisches Grundkonzept der identitätsorientierten Markenführung, p. 48).

167 Burmann/Meffert/Koers, Stellenwert und Gegenstand des Markenmanagements, p. 8; Esch/Langner/Rempel, Ansätze zur Erfassung und Entwicklung der Markenidentität, p. 106.

168 Burmann/Blinda/Nitschke, Konzeptionelle Grundlagen des identitätsbasierten Markenmanagements, p. 16 . 
tences, brand achievements, brand vision, brand values and brand personality. $^{169}$

Brand achievements determine form and configuration of products and/or services offered. The type of brand achievements chosen does not only determine the way the brand is being experienced by internal target audiences but also how the brand becomes utilisable for the end consumer. Implementation of brand identity by means of brand achievements as a central area of operative brand management comprises all decisions relating to marketdriven design of branded products and/or services. ${ }^{170}$ Brand achievements, therefore, include all those elements which can be protectable as trade marks, such as logos or packaging shapes. However, some brand achievements, which may in practice affect the brand image generated in consumers' minds, such as the smell of a certain type of leather used in a luxury car, cannot obtain such legal protection.

Brand identity components do not per se interrelate on a pre-defined cause and effect basis and vary in specific markedness and combination, over time and from brand to brand. This allows brand identity to be perceived and experienced as unique by customers. Like human identity, it can only develop over a certain period. ${ }^{171}$

Brand identity is a fundamental prerequisite for gaining trust within the target audience. ${ }^{172}$ Trust, in turn, is the basis of any long-term customer retention and brand loyalty. Since brand identity is a concept internal to the brand proprietor which is configured in the course of strategic brand management, it needs to be communicated appropriately in order to evoke the desired associations and reactions on the customer side. This is operationalised through positioning, which is part of operative brand management

169 For a detailed explanation of these elements cf. Burmann/Meffert, Theoretisches Grundkonzept der identitätsorientierten Markenführung, pp. 57-65. Kapferer's 'brand identity prism' is similar, consisting of the six facets physique, personality, relationship, cultures, reflection and self-image, cf. Kapferer, The new strategic brand management: creating and sustaining brand equity long term, pp. 106-111. Ultimately, terminology and scope of the components of brand identity may vary by author, yet what all publications have in common is the quest for elements reflecting an identity similar to a human one.

170 Burmann/Blinda/Nitschke, Konzeptionelle Grundlagen des identitätsbasierten Markenmanagements, pp. 21 and 35.

171 Kapferer, The new strategic brand management: creating and sustaining brand equity long term, p. 113.

172 Burmann/Meffert, Theoretisches Grundkonzept der identitätsorientierten Markenführung, p. 42. 


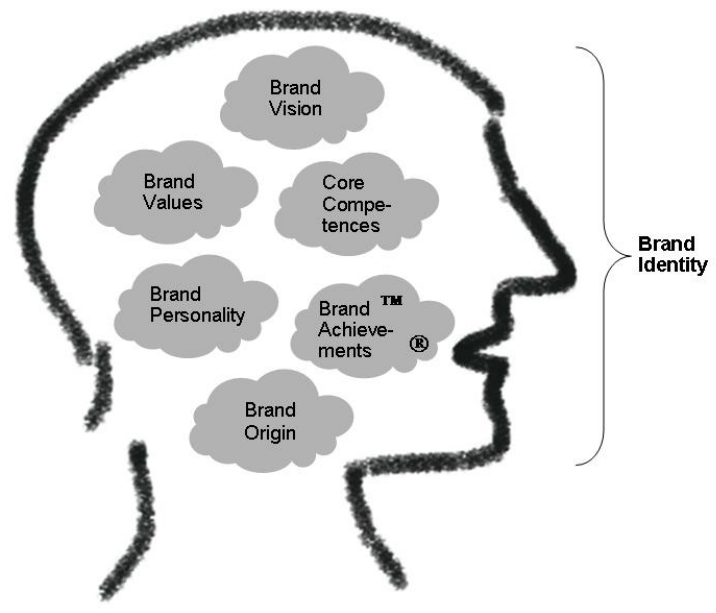

Figure 2.2: Brand identity (source: author's own on the basis of Burmann/Meffert, Theoretisches Grundkonzept der identitätsorientierten Markenführung, p. 57).

and determines how brand identity can be translated into core attributes being closely related to buying criteria of the relevant external target groups. ${ }^{173}$ By means of positioning, the respective brand is aimed at taking a position in the consumers' minds which is more favourable compared to those of competitors. ${ }^{174}$

In conclusion, brands are much more than formal signs of communication. They are complex personality-like constructs with their own behaviour, physical characteristics, values and visions. Based on their identity, they are able to create, shape and maintain strong relationships, both with external audiences such as end consumers and with internal target groups such as employees or suppliers. ${ }^{175}$ Brand identity, of which a brand's icons or devices are part, develops through both an internal collective process within the proprietor entity and interaction with external target audiences, who act on the basis of the image the respective brand creates in their minds.

In line with this holistic understanding, a brand can therefore be defined as "a bundle of benefits with specific characteristics which make sure that this bundle of benefits, from the point of view of relevant target audiences,

173 Burmann/Blinda/Nitschke, Konzeptionelle Grundlagen des identitätsbasierten Markenmanagements, p. 24.

174 See ibid.

175 Jansen, Brand Prototyping: Developing meaningful brands. 
strongly differentiates from other bundles of benefits meeting the same basic needs". ${ }^{176}$ Brands are central marketing means the devices or icons of which may be protectable by trade mark law.

As brands do not exist without providing added benefit for the customer visà-vis a fictitious unbranded product or service, they also cannot exist without products or services to carry them. Hence, they are not only intangible but also conditional assets. ${ }^{177}$

\subsection{Brand Types}

An enterprise's brand architecture defines how its various brands are arranged and interrelated. In this light, three kinds of brands can be distinguished: single (also called product or service) brands, family brands ${ }^{178}$ and corporate brands. ${ }^{179} 180$

Businesses choosing a single brand strategy provide a different brand for each of their products. The corporate brand, if at all, merely plays a background role vis-à-vis the external target audience. A brand family handles several related products under one brand. This is the case for many consumer goods companies, for example Beiersdorf and its brands Nivea, Hansaplast and others. ${ }^{181}$ In the course of a corporate brand strategy, all products or services are combined under one brand. SoNy is a good example of such a so-called 'branded house' (as opposed to a 'house of brands', which refers to a number of different single or family brands gathered under one umbrella brand, e.g. in the case of Unilever).

The credibility of brands for the target audience and thus their success and value depend to a considerable extent on how well the brand architecture is managed. Often, the above three strategies are combined in order to strive

176 Burmann/Blinda/Nitschke, Konzeptionelle Grundlagen des identitätsbasierten Markenmanagements, p. 3; Burmann/Meffert/Koers, Stellenwert und Gegenstand des Markenmanagements, p. 7.

177 Kapferer, The new strategic brand management: creating and sustaining brand equity long term, pp. 10/11. Similarly Henning-Bodewig/Kur, Marke und Verbraucher: Funktionen der Marke in der Marktwirtschaft, p. 226.

178 These are also known as 'product line names', cf. Bamert, Markenwert, p. 83.

179 Corporate brands are also denoted 'umbrella brands' or 'company brands', cf. Bamert, Markenwert, p. 85.

180 Böhler/Scigliano, Marketing-Management, pp. 105 et seq.

181 Cf. http://www.beiersdorf.de/controller.aspx?n=51 \\&l=1 (last accessed July 4, 2007). 
for clear brand positioning, to utilise possible positive image transfers between brands and to take advantage of brand strategic options ${ }^{182}$ without overexpanding the respective brands. ${ }^{183}$

Next to the dimension of brand architecture just introduced, there exists a trade directed dimension, which relates to the business' positioning in vertical competition. ${ }^{184}$ On the basis of this dimension, the respective business needs to decide whether it shall solely operate as a classical producer of branded goods and/or supply the intermediaries with goods for their private labels. Hence, one can distinguish the 'classical' brands and private labels or store brands respectively. ${ }^{185}$

\subsection{Brand Functions}

Just as brands consist of more elements than trade marks, they show a greater variety of functions over and above the origin and differentiation functions of the latter. Depending on whether one takes the point of view of the brand proprietor, the target audience or an intermediary, different brand functions are important.

For the offeror, a strong brand causes preference generation and customer loyalty. Furthermore, it facilitates segment-specific market cultivation as each segment can be addressed with specifically matched messages. In consequence, a strong, well-managed brand brings about the possibility of demanding price premia other brands are not able to achieve. ${ }^{186}$ Such higher prices imply higher profitability, unless pressure from competitors reduces profits to normal levels. ${ }^{187}$ Customers' price elasticity of demand ${ }^{188}$ tends to

182 Such options include line extensions, in the course of which an existing brand is extended to a new product within an existing product group, brand extensions, which are used to transfer an existing brand to a new or different product group, and others; cf. Kaufmann/Sattler/Völckner, Markenstrategische Optionen, pp. 2 et seq.

183 Homburg/Krohmer, Grundlagen des Marketingmanagements. Einführung in Strategie, Instrumente, Umsetzung und Unternehmensführung, p. 185 et seq.

184 Thirdly, there is also a horizontal dimension of brand architecture, which refers to the number of offered brands per market segment, cf. Burmann/Blinda/Nitschke, Konzeptionelle Grundlagen des identitätsbasierten Markenmanagements, pp. 25-29.

185 As to an example for such brands cf. fn. 129.

186 Esch/Wicke/Rempel, Herausforderungen und Aufgaben des Markenmanagements, p. 12.

187 Greenhalgh/Rogers, Trade Marks and Market Value in UK Firms, p. 4.

188 This term denotes buyers' responsiveness or sensitivity to changes in price, cf. Silbiger, The 10-day MBA, p. 294. In premium branded segments, for example, elasticity is 
be lower than regarding weak brands or store brands, which means that a possible price increase causes comparatively little abstinence or migration to other products or services. Hence, buyer behaviour becomes less volatile which lowers the proprietor's sales and earnings risks. Such lowered risks lead to lower discount rates in the course of company valuation which results in an increase in company value itself. ${ }^{189}$

Furthermore, strong brands contribute to lowering cost of capital for the proprietor. Each bank passes through a rating process prior to granting a loan. According to new 'Basel II' risk assessment rules, the rating depends to a large extent on balance sheet figures but also on qualitative factors such as market position. ${ }^{190}$ Hence, the stronger and more valuable the brand, the higher the creditworthiness of the proprietor and the lower the interest rate, i.e. the cost of capital.

The abovementioned implies that strong brands protect the offeror's products or services from competitor influence. This, however, does not mean that a strong brand makes the owner immune against all negative implications. Rather, a particular problem with a brand or the branded goods or services may cause the proprietor to need a considerable amount of money to immediately rebuild and reposition the brand. Take the example of PERRIER: in the year 1990, a number of PERRIER water bottles were contaminated with benzene during routine maintenance. This incident required the company to spend $£ 84$ million for the repositioning of the product in addition to $£ 125$ million in price reduction when the drinks division was put off. ${ }^{191}$ The interconnection between these risks and the trade mark's and therefore the brand's value is crucial to keep in mind for the long-term effectiveness of brand management success.

Furthermore, strong brands allow, by enabling certain sales and earnings volumes, the proprietor to negotiate relatively good deals with suppliers. The proprietor's lowered risk is being passed on to suppliers who, in turn, often accept agreements favourable for the offeror. In a similar manner, brands provide an advantageous negotiating position vis-à-vis retailers. ${ }^{192}$

generally lower than in low-cost segments, enabling the brand proprietor to demand higher prices without necessarily losing a considerable number of customers.

189 Bamert, Markenwert, p. 51.

190 Kudraß/Schäfer, BC 2003, 35, 36.

191 Gream, Trademark valuation: review in January 2004, p. 4.

192 Baumgarth, Markenpolitik. Markenwirkungen - Markenführung - Markencontrolling, 
What is more, a strong brand may constitute an enabling platform for new products or services in the course of brand extensions, line extensions ${ }^{193}$ and other strategic options such as new distribution channels or new geographic markets. ${ }^{194}$

Like for proprietors, risk reduction is one of the central brand functions from a customer's point of view. As set out above, the information a brand conveys and experiences consumers have with the brand build a specific brand image in consumers' minds. As buying decisions are generally made on the basis of incomplete information, a positive experience and therefore a favourable brand image raise the likelihood of repurchase considerably. Strong brands can therefore significantly facilitate and accelerate the decision making process and thereby lower transaction cost. ${ }^{195}$ This reduced complexity provides orientation and lowers risk of buying something unknown or unwanted. The certitude and trust a strong brand conveys do not only reduce this functional risk (related to performance) but also economic risk (linked to price), experiential or social risk (related to customers' experience with the product or their social image respectively). ${ }^{196}$ Due to such risk perceived by customers, the offeror needs to build trust within the target audience. The main instrument for achieving this is a strong brand. ${ }^{197}$ Closely linked to experiential risk is the issue of quality. As every brand conveys a certain statement with respect to the quality of the marked product or service, brands can, if they are experienced positively by customers, function as a quality guarantee and orientation in this regard (so-called warranty function).

p. 22. Note that currently only the two strongest consumer goods brands are able to keep or increase their market share; others lose market share to store brands, cf. Esch/Wicke/Rempel, Herausforderungen und Aufgaben des Markenmanagements, p. 12.

193 For an explanation of these terms cf. fn. 182.

194 Kaufmann/Sattler/Völckner, Markenstrategische Optionen, pp. 2 et seq.

195 Bamert, Markenwert, p. 47.

196 Kapferer, The new strategic brand management: creating and sustaining brand equity long term, p. 11.

197 Eva Wellendorff of Schmuckmanufaktur Wellendorff in Pforzheim, Germany, in 2001: "Eine unverwechselbare Marke gibt dem Kunden Sicherheit." ('A unique brand gives the customer certainty.'), cf. http://www.gem-online.de/markendefinitionen/index.ph $\mathrm{p} ? \mathrm{id}=16 \backslash \&$ keyword $=($ last accessed July 11, 2006). Karl Popp, then president of the Austrian branded goods association, similarly said in 1997: "In einer immer unsicherer werdenden Welt bietet die Marke das, was die Menschen sich wünschen: Sicherheit Vertrauen - Qualität." ('In a world becoming increasingly insecure, the brand offers what people wish for: Certainty - trust - quality.'), cf. http://www.gem-online.de/ma rkendefinitionen/index.php?id=12 \&keyword= (last accessed July 11, 2006). 
For consumers, brands also fulfil a social image or prestige function. As early as in the 19th century, William James was aware of the fact that a "man's self is the sum total of all that he can call his, not only his body and his psychic power, but his clothes and house, his wife and children, his ancestors and friends, his reputation and works, his lands and yacht and bank account. All these things give him the same emotions.". ${ }^{198}$ In this light, brands can act as means of outward communication of one's own personality. Inversely, consumers can utilise brands in order to define their own identity by conferring certain brand attributes to themselves. They can thereby show social group membership. In some cases, brands even give meaning in a quasi-religious way. ${ }^{199}$

\subsubsection{Intermediate Findings}

The preceding details have shown that trade marks and brands are overlapping but distinct. A trade mark, as a legal concept, is a government-granted exclusivity right which is renewable ad infinitum. It can be defined as a sign or combination thereof, provided that such signs are capable of distinguishing goods or services from one undertaking from those of another. As such, it performs functions of origin and differentiation, both of which are important for assessment of important points of trade mark registrability and infringement.

A trade mark is, if used in practice, always accompanied by marketing elements in combination with which it constitutes a brand. Hence, a trade mark is a brand inasmuch as it is protected by trade mark law. For this reason, this work is concerned with brand valuation instead of merely with trade mark valuation.

A brand is a complex, personality-like phenomenon with the interrelating components brand identity and image. It can be defined as a bundle of specific benefits which ensures that it - from the viewpoint of relevant target audiences - strongly differentiates from other such bundles meeting the same needs. Brand achievements, as components of brand identity, comprise the market-oriented signage (also known as devices), such as logos, sounds or specifically designed smells, some of which is protectable as trade marks.

198 James, The Principles of Psychology, p. 291; as cited by Burmann/Meffert/Koers, Stellenwert und Gegenstand des Markenmanagements, p. 12.

199

Bamert, Markenwert, p. 49. 
Brands affect almost every sector of the respective business. Brand management, therefore, needs to be carried out in a holistic way. If this is done successfully, the respective brand will be able to generate and maintain a strong and positive consumer relationship, reducing risk and lowering transaction cost on both sides. What is more, it will ensure relatively low cost of capital. In addition, strong brands can open up strategic options for the proprietor and (especially in some sectors, e.g. the luxury car sector) fulfil a social prestige function for the respective (internal and especially) external target groups.

\subsubsection{Findings}

Both trade marks and brands are intangible assets. Trade Marks, in particular, belong to the subgroup of intellectual property and can be part of the signage or device part of brands. In other words, the part of a brand known as a device can be protected as one or several trade marks, but this is not a conditio sine qua non for the existence of a brand.

For purposes of comprehensive brand valuation, it is important to understand both nature and functions of brands as these are value influencing factors. It has therefore been elaborated that brands bring about certain characteristics both due to their belonging to the group of intangible assets and due to their nature as complex, personality-like phenomena. These characteristics and functions, such as the ability and potential to reduce certain risks, need to be operationalised in any proper valuation tool for use in the course of comprehensive strategic (i.e. future-related) valuations.

\subsection{Introduction to Brand Valuation}

\subsubsection{Development of Brand Valuation}

The first brand valuation literature was publicised as early as $1962,{ }^{200}$ yet the topic was hardly mentioned in the period before $1985 .{ }^{201}$

200 Kern, Betriebswirtschaftliche Forschung und Praxis 1962, 17.

201 Kapferer, The New Strategic Brand Management: creating and sustaining brand equity long term, p. 443. 
It was not until the late 1980s that brand valuation became a concept which was increasingly used in business. Widespread takeover bids for and acquisitions of large brand-focussed companies sparked this process. Many businesses sought to enlarge their brand portfolios for reasons such as cost savings in production and distribution and the fact that the development and management of new brands is sumptuous. ${ }^{202}$ As it was expressed in a 1985 Los Angeles Times article, "In recent weeks, the business world watched as almost $\$ 15$ billion and about 400 brand names changed hands in rapid-fire sequence. Before the dust began to settle, Procter \& Gamble owned Richardson-Vicks, Philip Morris Inc. had General Foods, R.J. Reynolds Industries consumed Nabisco Brands and Monsanto took G.D. Searle \& Co. [...] The brand name suddenly has emerged as the most coveted corporate asset of all. Brands no longer are merely products competing for market share; they're annuities being plugged into the big-money equations of corporate acquisitions. It has become wiser to grab somebody else's established brands and extend the lines than spend $\$ 80$ million or more trying to get a new name into the mix." ${ }^{203}$

Hence, the hidden value generated by brands began to be unveiled as large sums were paid for companies whose tangible assets' value was estimated to be far lower than the actually paid price. When Philip Morris bought Kraft Foods for US $\$ 12.9$ billion in 1988, 11.6 billion US $\$$ were estimated to account for the brand value. ${ }^{204} 205$ This was and still is due to the fact that internally generated brands may not be posted in the balance sheet. Another reason for increasing need of brand valuation was that every single merger and acquisition transaction necessarily involves a pricing process.

Furthermore, in the late 1980s, a number of British companies such as Cadbury Schweppes and Guinness sparked a brand accounting debate by including acquired brands as separate assets on the balance sheet (instead of leaving them as not recognisable parts of goodwill, which was widespread practice at that time). ${ }^{206}$ The intensive discussions raised thereby contributed to an

202 It is estimated that the complete development of a new brand in the USA, Europe and the Middle East costs approximately one billion US \$, cf. Häusler/Stucky, Markenmanagement und finanzielle Transaktionen, p. 6.

203 Los Angeles Times, 1985, as cited by Tauber, 16 Journal of Advertising Research, iss. 4, 26, 26 (1988).

204 Farquhar/Han/Ijiri, 1 Marketing Management, 16, 16-22 (1992).

205 This brand takeover spree was not just an American phenomenon but could be observed in virtually all developed economies. For instance, Nestlé acquired Rowntree and Danone took over Nabisco's European business. 
increasing focus on brand value and its measurement.

In those days, globalisation, increased competition, the establishment of free trade zones, deregulation and privatisation, faster product life cycles, mergers $\&$ acquisitions as well as divestments, shortage of highly qualified personnel, public expectance of companies' social commitment and increased importance of external stakeholders for corporations started to form a changing economic framework which encouraged increased focus on brands and their valuation. ${ }^{207}$ Common today yet novel at the time, businesses in developed economies, on a world-wide scale, aimed to live up to these requirements by not merely offering products or services, but also an additional offering in the form of brands which the consumer connects to the acquired product or service. Analogously, companies did not merely choose to acquire e.g. a sweets or biscuits manufacturer any more but Rowntree or Nabisco respectively.

The fact that acquired brands were able to attain high sums in merger and acquisition transactions was not without effect on internally generated brands. The first such brand valuation for balance sheet purposes made public was carried out by Interbrand for the UK pastries producer Rank Hovis McDougall (RHM) which in the year 1988 was under threat of a hostile takeover by the Australian food concern Goodman Fielder Wattie. ${ }^{208}$ RHM's management believed its assets, especially its brands, to be undervalued and hired the consultancy to put a price tag on their assets in order to be able to fight the takeover bid. This exercise succeeded in putting the worth of the company's brands as a figure on the balance sheet. With the brand value information, the RHM board was able to argue vis-à-vis investors that the bid was too low and eventually repel it. ${ }^{209}$

Today, since intangible assets have come to constitute the lion's share of many modern companies' value, ${ }^{210}$ valuation of these assets is increasingly in

206 Havenstein/Heiden, BB 2003, 1272, 1273.

207 Zednik/Strebinger, Marken-Modelle in der Praxis. Darstellung, Analyse und kritische Würdigung, pp. 5-6.

208 Häusler/Stucky, Markenmanagement und finanzielle Transaktionen, p. 7; Stucky, Monetäre Markenbewertung nach dem Interbrand-Ansatz, p. 433.

209 RHM was eventually acquired in 1992 by the US conglomerate Tomkins Plc., which sold it off to the UK company Premier Foods in March 2007; cf. http://www.an swers.com/topic/ranks-hovis-mcdougall-limited and http://www.flexnews.com/page $\mathrm{s} / 7813 /$ Premier/RHM/premier $\backslash \_$foods $\backslash$ _completes $\backslash$ rhhm $\backslash$ _acquisition.html (both last accessed March 27, 2007).

210 Research carried out by PricewaterhouseCoopers shows that intangible assets and goodwill constituted up to $74 \%$ of the average purchase price of companies in the year 
focus. Branding has become the standard procedure in almost every branch of industry. Correspondingly, the number of trade marks and brands has been rising clearly for quite some time. For example, the number of Germanyonly trade marks registered with the German Patent and Trade Mark Office rose from 0.57 million at the end of 1998 at averaged about $4.8 \%$ p.a. to 0.70 million at the end of $2003^{211}$ and to almost 0.77 million by the end of $2007 .{ }^{212}$ What is more, there have been and still are phases of strong Merger and Acquisition (M\&A) activity, in which brands often play a key role. ${ }^{213}$

Given the increased popularity and economic prominence of brands, it is no surprise that brand valuation models have gained considerable attention since the late 1980s, both in science and practice. While it is generally agreed that brands are of utmost importance for the respective company and that brands constitute a major part of many companies' overall value, the actual determination of brand value is often being neglected. ${ }^{214}$ Hence, it has not been possible to develop a generally or at least widely accepted brand valuation method. In fact, there exist a large number of different brand valuation methods which results both in an overly complex valuation market and in a missing comparability and significance of the established values. ${ }^{215}$

\subsubsection{Definition and Origins of Brand Value}

In order to be able to find the value of a specific object, it is indispensable for any valuator to understand what the term 'value' means. Inextricably linked to this issue is the question why a certain item is valuable or has the potential to become so.

\subsubsection{Brand Value Defined}

Being questioned what value of an intellectual property right is, a member of the audience at a conference on IP valuation"16 answered: "Value is what the

2003, see Rugman/Hadjiloucas, Valuing IP and determining the cost of capital, p. 1.

211 Gerpott/Thomas, WiSt 2004, 394, 394.

212 Deutsches Patent- und Markenamt, Jahresbericht 2007, pp. 11, 34.

213 According to Thomson Financial, European M\&A activity reached US \$ 1.29 billion by the end of July 2007, which is more than the total for 2006, cf. Saigol, Lights go down on the acquisition party.

214 Wirtz/Göttgens/Dunz, der markt 2001, 159, 159. Reasons for this abstinence from practical brand valuation are presented in chapter three at 3.1.1.

215 More on this below in chapter three at 3.1.1 et al. 
respective item sells for." This market-based approach to (financial) value is the most self-evident one. The value the sold item has in the eyes of each party is condensed in its (usually monetary) quid pro quo at the moment of transaction. $^{217}$

The abovementioned market value related statement met with a divided response. Others defined value as the utility the respective IP right has for the proprietor. This reflects the fact that value is a relative concept. It always depends on the respective situation and lies in the eye of the beholder. What is more, utility is (as well as scarcity and title), ${ }^{218}$ in a desired market situation and as just indicated, reflected by the attained price so that the market approach and the utility-based view are not separate but parts and expressions of the same construct.

Value, in general, can be financial or non-monetary. An old family photograph can, for instance, be very valuable to a person due to fond memories of times bygone. Such an affectionate value is very unlikely to be expressible in monetary terms and would almost certainly differ from value potentially recognised by a particular market or industry. Yet unless the person would want or have to alienate the photograph, he or she is not obliged to find a financial expression for its value. In other words, the utility the photograph has for the owner (plus scarcity and title) ${ }^{219}$ do not mirror a financial value unless such value is needed.

Expressions of value in financial terms is needed for purposes of documentation and whenever transactions take place. Except for a situation of a simple barter, money is the currency of transactions. Transactions in this sense not only include company-external sales or licences, but also company-internal ones, e.g. for transfer pricing and portfolio management purposes.

Monetary value, of all assets including brands, can therefore be defined as

216 'Bewertung von IPRs', Königswinter, Germany, May 18-19, 2006.

217 Ideally, such transaction has been carried out in a transparent market as there is no more reliable and accurate reflection of value than in a transparent market transaction just carried out. In such a transparent market, the monetary quid pro quo for which an item changes hands reflects not only what the item is worth to each party in a certain setting but also value-related informational and volitional symmetry or consent between the parties. Pricing information arrived at in such a fashion could then be widely used for similar transactions by other market participants. In the case of IP and of brands especially, this faces difficulties as there are no sufficiently transparent markets and these assets are highly unique.

218 Supra at 1.3.

219 Cf. above at 1.3 . 
the estimated quantity of financial assets for which an item changes hands "on the date of valuation between a willing buyer and a willing seller in an arm's-length transaction after proper marketing wherein the parties had each acted knowledgeably, prudently, and without compulsion". ${ }^{220}$

The fact that this definition reflects an ideal market situation which will almost never be attained in practice mirrors the circumstance that valuation is not an exact art (except for those cases in which one deals with fixed, historic data only, e.g. in accounting situations). The economic concept of value refers to the price most likely to be agreed on by the respective parties to a transaction. Hence, instead of being a fact, future-related value is by definition an estimate.

This conclusion is valid for all types of asset, tangible and intangible. Therefore, as a basic rule, one should not subject the valuation of intangible assets to more demanding requirements than valuation of tangible assets. The (future-related) valuation of a house and of a brand are both, in essence, estimates, the major difference being that there will generally be more objectified market information available with respect to the house than the brand. This is due to the nontradable nature of brands and other intangible assets. ${ }^{221}$ There are no markets for trade marks or brands which show an acceptable degree of minimum transparency.

However, this does not mean that the definition of value becomes futile or invalid. Rather, the logical consequence is that the diligent valuator will have to find a way to collect as much information as possible about the respective brand in order to fill information gaps existing compared to relatively frequently traded tangible or financial assets such as cars or company shares.

Hence, a valuation methodology suitable for future-related valuations should be capable of collecting such information in a systematic way, thereby enabling the valuator to carry out the value estimate as reliably as possible. ${ }^{222}$

The financial world, for the most part, sees brand value as the profit which can be attributed to the brand and which the brand owner could not attain without the brand. ${ }^{223}$ In other words, a brand's value is said to be mirrored

220 International Valuation Standards Committee, International Valuation Standards, p. 27.

221 Cf. 2.1.1.3.4, supra.

222 Cf. above, 1.4.1.6.

223 Amirkhizi, "Suche nach der Weltformel". 
by the net present value of all future income surplus which the proprietor is able to derive from the brand. ${ }^{224}$ This definition is not able to comprehend all items influencing the value of an IP right or a brand. However, it can be used as part of a future-related monetary brand valuation tool, since the ability to generate cash flows is one of the main utilities of a brand and would therefore strongly influence a possible market value. However, in order to gather as much salient information on the respective brand in order to approximate a market situation as realistically as possible, it is essential to realise that the value of all IP assets and especially brands can only be fully understood and operationalised in light of the context in which the respective asset stands. Such context includes, for example, integration of the proprietor company's brand and IP strategy, the characteristics of the brand portfolio, interrelations with other assets, market information and so forth. ${ }^{225}$

\subsubsection{Sources of Brand Value}

As just explained, one central origin of brand value is their potential to generate cash flows. A strong brand is able to leave a positive image in customers' minds which, combined with positive experiences during and after initial purchase, encourages the consumer to purchase the same product or service again. Hence, by providing security of demand, it assures positive cash-flows for the proprietor company while reducing several types of risk for proprietor, customer and intermediary, as set forth above. ${ }^{226}$ This security of demand means a security of future brand earnings, which is a major component of brand value. From a financial viewpoint, the value of brands lies therefore mainly in their function to on the one hand accelerate and extend future cash-flows of a company and on the other hand reduce the risk of future cash-flows. ${ }^{227}$

As elaborated above, these are not the only risks mitigated by well-managed brands. However, ultimately, risks such as functional and social ones are reflected in buyer behaviour and sales volume. Hence, they are linked to the cash-flow risk.

224 Esch/Geus, Ansätze zur Messung des Markenwerts, p. 1265.

225 A deeper discussion of this would divert too strongly from the examination of brand value at this point. The issue how brands should best be valued will be discussed in detail in chapters three and four.

226 At 2.1.2.2.3.

227 Srivastava/Shervani/Fahey, 62 Journal of Marketing, iss. 1, 2, 10-14 (Jan. 1998). 
Furthermore, as seen above, brands are, in general, valuable because their trade mark component provides for scarcity due to legal protection. ${ }^{228}$ This constitutes the dogmatic foundation of a brand's potential to develop a value. Conceptionally, legal scarcity caused by trade mark protection, whether by registration, by acquired distinctiveness or notoriety, is not essential for the brand to become strong and successful. However, in most cases, trade mark protection is essential, especially during initial branding and market entry phases in which the brand has not yet gained a standing in the marketplace (protection would in this case be achieved by registration). The trade mark component of the brand, if duly looked after, secures freedom to operate within the goods or services classes and the territory it was registered for. It thereby opens up the potential to become known to target audiences, generate revenue and profit. ${ }^{229}$

Ultimately, all brand functions contribute to brand value. The quality in which they - and with them the whole brand - are managed are decisive for the valuation outcome. Correspondingly, a proper valuation methodology needs to handle all important brand functions.

\subsubsection{Findings}

Compared to valuation of tangible assets, brand valuation is a relatively young art. Science and practice began to deal with brand value on a considerable scale induced by the mid-1980s brand-focussed corporate takeover sprees. In the course of a brand value discussion for both accounting and management purposes, a large number of valuation methods have been developed.

As the price attained in an (ideal) transparent market transaction best reflects the value of the respective asset in monetary terms, brand value can be defined as the estimated quantity of financial assets for which the brand changes hands between willing and informed parties in an arm's length transaction on the date of valuation.

As a consequence, a proper valuation methodology needs to come as close to such a transaction as possible. Since market mechanisms can usually

228 Cf. 2.1.1.3.7.

229 In addition, the trade mark and brand as a whole are also subject to protection through other legal regimes such as (trade) name and competition law. 
not be resorted to and brands and different IP assets of the same kind are hardly comparable, a brand valuation tool, today, cannot utlilse market data. Rather, it should operationalise as much information about the respective brand as possible, including the brand's ability to mitigate a number of risks. Such a holistic valuation allows for well-informed and reliable value outcomes coupled with best possible understanding of the respective IP right. It thereby approximates a transparent market transaction as closely as possible and could, if commonly used, help create IP markets. Furthermore, such modus operandi facilitates management of brand and IP and their exploitation as assets.

\subsection{Reasons for Brand Valuation}

In addition to the 'what' and 'how' of valuation which have been discussed in chapter one and the first two parts of this chapter, ${ }^{230}$ every diligent valuator needs to know the 'why' and the objectives thus to be achieved. These topics will be illuminated in the following.

Situations requiring valuation of brands and other IP are manifold. Next to value documentation for accounting, tax and litigation purposes, financial brand value constitutes an important measure of success to be used in the course of strategic brand controlling, for exploitation of brands through certain types of transactions and for purposes of brand finance. Accordingly, in order to establish a systematic overview of valuation-demanding scenarios, this study distinguishes the subgroups strategic brand management and communication, brand transactions, brand finance, brand protection as well as accounting and tax. ${ }^{231} 232$

230 The issue how IP and brand valuation should best be performed is a central theme of this work and will also be discussed in chapters three and four.

231 This functional differentiation is similar to Sattler, Markenbewertung: State of the Art, p. 4. Others distinguish voluntary and compulsory valuations, internal and external purposes or regular and sporadic valuation (cf. Gerpott/Thomas, WiSt 2004, 395). Such approaches would, however, lack the necessary degree of selectivity and expressiveness.

232 Company valuation for initial public offerings (IPOs) and brand leasing are two situations requiring brand valuation which will not be mentioned in the following due to their rather low practical occurrence. Equally, the fact that trade marks can be used as investment in kind as means of raising nominal capital for German limited liability companies is of more theoretical than practical nature and shall therefore only be mentioned at this point. Interested readers will find more information in Nabrotzki, 

trolling

As stated above, brands exert major influence on the overall value of many companies since they constitute important engines of value creation. Therefore, brand management means consistent value management. Still, the valueadding potential of many brands is not being fully exploited. ${ }^{233}$

In order to improve this situation, it is, first of all, crucial to realise that brands do not only have an impact on other intellectual property assets held by the company but, as a strategic asset, on almost all functional divisions of a business. Furthermore, the fact that brand management measures are, generally, cost-intensive and long-term bears, especially in the light of shortened reporting periods, increased conflict potential and justification pressure on brand managers. ${ }^{234}$ Comprehensive brand valuation, independently and regularly carried out, can help ease such pressure and conflicts considerably by showing and steering a sustainable successful brand management process.

Ideally, brands are part of an overall IP strategy of a company and therefore used to leverage off other existing IP, mostly patents. ${ }^{235}$ For example, in most cases, cost of applying for patents in every possible country will exceed the benefit. Therefore, many companies resort to patenting in countries for which they expect the highest returns on investment and receiving product recognition by registering trade marks in more countries as a complementary protection. ${ }^{236}$ This dual or complementary IP protection behaviour reduces overall cost of patenting while creating demand and recognition for the patented product in countries without patent protection, thus maximising return on investment (ROI).

As set forth above, brands are complex, personality-like constructs with both an identity (self-perception) and an image (outsider's perception), which bear

Lizenzen an Immaterialgüterrechten als Mittel der Kapitalaufbringung and Werwigk, Kapitalaufbringung durch Immaterialgüterrechte, pp. 18-88.

233 Sander/Jakobs, marketingjournal 2004, 34, 34.

234 Havenstein/Heiden, BB 2003, 1272, 1272.

235 Regarding the strategic link between patents and brands in the light of increasing shareholder value, cf. e.g. Berman/Woods, Patent "Brands" - Positioning IP for Shareholder Value, pp. 211-231 and Loschelder, GRUR Int. 2004, 767, the latter discussing European and German case law.

236 This is, for instance, what the Australian health care company ITL did; see http: //www.wipo.int/sme/en/case \_studies/itl.htm (last accessed May 1, 2006). 
a relation to each other. ${ }^{237}$ Hence, brands need to be managed including both these perspectives. Conception of a brand identity belongs to (together with development of a brand architecture and other topics) strategic brand management. Operative brand management is tasked with its implementation. Brand identity needs to be implemented, amongst others, through positioning and communicating brand achievements. A successful brand identity can only be achieved if the brand is lived consistently by all internal stakeholders, from employees to management (so-called brand citizenship behaviour), and externally communicated in a consistent way. A strong brand image in consumers' minds enables a successful long-term brand-consumer relationship and thereby positive cash flow generated by the brand. It is created by positioning selected brand identity components. This positioning is carried out through marketing means which will be introduced below.

As a consequence of such holistic understanding of brand management, the group of responsible persons comprises far more individuals than merely marketing managers. Brand management, if done properly, is a cross-sectional task. Management and employees shape brand identity and image on a daily basis, be it by direct contact with other stakeholders or indirectly, for example in the course of product development. The brand's value proposition needs to both be communicated consistently and be satisfied effectively by the product and/or service offering. In order to secure and improve brand success long-term, all this needs to be reviewed on a continued basis by means of a holistic brand steering and controlling process. Misdirected investment and management can have fatal implications for all divisions of a business. Hence, the topic of brand management and therefore of brand (e)valuation needs to be addressed at and steered from upper management or board level.

The overall goal of brand management is the increase of brand and thereby of company value. As this overall goal cannot be reached directly, ${ }^{238}$ it needs to be accomplished indirectly by means of brand identity, which through positioning creates awareness (as a necessary precondition for origination of brand image) and image. ${ }^{239}$ These, in turn, serve the purpose of economic goals such as market share and turnover, which directly affect brand and thereby company value. ${ }^{240}$ As a consequence, the respective brand needs to 
be valued regularly in order to measure the degree of success of brand management activities. Insights gained from such comprehensive (e)valuation provide valuable information for use in a necessary constant brand management review and improvement process as valuation is a highly effective ROI benchmark. It allows brand managers to be assessed appropriately on the added value their work creates. ${ }^{241}$ Insights should include analyses of the respective brand relative to competitors', identification of potential opportunities, strengths and weaknesses of the brand, its risk reduction ability or potential and consumer market perceptions.

The general framework determining success or failure of brand management is complex nowadays. For instance, important issues to be dealt with are, amongst others, information overload, ${ }^{242}$ changed buyer behaviour (smart shopping, variety seeking etc.), increased international competition, increasing share of trade brands with respect to overall turnover, decreasing uniqueness and distinctive character of trade marks and brands, converging product quality, shorter product life cycles ${ }^{243}$ and increasing brand piracy. ${ }^{244}$ Such issues therefore need to be operationalised in a brand valuation methodology used for strategic brand management purposes.

240 Esch/Wicke/Rempel, Herausforderungen und Aufgaben des Markenmanagements, pp. 42-51.

241 According to a study carried out by Günther and Kriegbaum-Kling in 1999, 69.3\% of all 128 respondents stated that brand valuation is a suitable measure to assess performance of those responsible for it, cf. Günther/Kriegbaum-Kling, Schmalenbach Business Review 2001, 263, 277.

242 Communication is becoming increasingly inefficient due to its ubiquity. It is estimated that, in Germany, only $2 \%$ of all information is actually absorbed by customers, cf. Baumgarth, Markenpolitik. Markenwirkungen - Markenführung - Markencontrolling, p. 17. In the light of the average 3,000 commercial messages to which the ordinary person is exposed daily, this is not very surprising, cf. Toubassy, Brand Licensing. A misunderstood piece of the marketing mix, p. 1.

243 This is closely linked to, amongst others, ephemerality of technical innovations compared to similar developments made by competitors. Together with increased global business pressure, an environment of intensified urgency to make short-term decisions has emerged. This can have negative implications on the respective brands as they have to be managed with a long-term perspective. Brand valuation provides an opportunity to uncover short-term misperceptions and improve the brand management process and thereby the health of the respective brand. According to the 1999 study by Günther and Kriegbaum-Kling, 81.9\% of the respondents stated that brand value as a performance measure offers incentives for a long-term and value increasing behaviour, cf. Günther/Kriegbaum-Kling, Schmalenbach Business Review 2001, 263, 277.

244 Baumgarth, Markenpolitik. Markenwirkungen - Markenführung - Markencontrolling, pp. 10 et seq. 


\subsubsection{Marketing - Planning, Implementation and Control}

As a central component of brand management, marketing shall briefly be highlighted in the following. Like all other brand management instruments, marketing means need to be constantly revisited, reviewed and evolved. A holistic brand valuation or rather evaluation methodology serves as an important resource of guidance in this context.

Marketing is not confined to market communication such as advertising. Rather, it is a fundamental and far-reaching task touching almost every section of a business. The way a marketing concept is established and implemented can vary conspicuously from marketing manager to marketing manager and from company to company. Marketing is a dynamic process during which priority setting can take a variety of forms. For these reasons, there are many definitions of marketing. A viable one defines marketing as the planning and implementation process of the conception, pricing, advancement and dissemination of ideas, products and services in order to effectuate processes of interexchange for satisfaction of individual and organisational objectives' ${ }^{245}$

The classic marketing instruments, the so-called 'marketing mix' or 'four Ps', serve to practically implement the respective marketing strategy. They comprise product, price, place and promotion. ${ }^{246}$ These instruments need to be tailored to the respective goals and needs in the course of planning and implementation of each company's brand and marketing strategies. The respective brand identity, as strategically planned, is implemented with the aid of these marketing instruments in the course of operative brand management. ${ }^{247}$

Product policy includes all activities on composition of the market output of the respective company, such as product configuration, additional output, styling, design and branding. ${ }^{248}$ In the course of the pricing policy, the general pricing level (top price vs. medium or low price segment) and the pricing

245 Meckl, Übung: Funktionsbezogenes Internationales Management (IM) - SBWL IM III, slide 2.

246 Homburg/Krohmer, Grundlagen des Marketingmanagements. Einführung in Strategie, Instrumente, Umsetzung und Unternehmensführung, p. 158; Irmscher, Markenwertmanagement. Aufbau und Erhalt von Markenwissen und -vertrauen im Wettbewerb, pp. 216-266.

247 Burmann/Blinda/Nitschke, Konzeptionelle Grundlagen des identitätsbasierten Markenmanagements, pp. 34-42.

248 Baumgarth, Markenpolitik. Markenwirkungen - Markenführung - Markencontrolling, p. 196. 
strategy over time are being defined. ${ }^{249}$ 'Place' refers to distribution policy. Significant issues in this context are the constitution of the distribution system (such as selection of sales agents, licenced dealers, wholesale etc.), of the cooperation with distribution partners and of sales activities. ${ }^{250}$ Lastly, the promotion policy of a business defines how information which is designed to influence the audience in favour of the branded goods or services is to be designed and communicated. ${ }^{251}$ There are classical means of communication, such as advertising, public relation and sponsoring, and non-classical ones such as events, giveaways and mobile marketing. ${ }^{252}$

In the course of value-based management, more or less all disbursements within businesses are seen as investments and therefore scrutinised for profitability. Often, marketing managers lack an objective, quantitative and qualitative instrument to justify budget requests and decisions with respect to investments in a brand. In general, this tends to result in underinvestment. Yet even if the volume of investment in the brand is optimal, inefficient budget allocation decisions cannot be precluded without feedback through comprehensive brand valuation and evaluation, which give detailed information about the brand's performance and significance.

Marketing information and planning are closely linked to marketing control (which is, for instance, carried out by portfolio analysis). The co-ordination of information, planning and control is known as controlling. It serves to provide information for, amongst others, strategic and operative planning, portfolio management, market segmentation and monitoring of results. ${ }^{253}$ As such, it is of vital assistance for marketing management. Comprehensive brand (e)valuation, for instance as proposed in this work, can provide quantitative and qualitative information about the respective brand (such as brand strength or sales volumes) which is crucial throughout the controlling process.

249 Böhler/Scigliano, Marketing-Management, pp. 156-161.

250 Homburg/Krohmer, Grundlagen des Marketingmanagements. Einführung in Strategie, Instrumente, Umsetzung und Unternehmensführung, p. 266.

251 Ibid., p. 222.

252 Baumgarth, Markenpolitik. Markenwirkungen - Markenführung - Markencontrolling, p. 194.

253 Böhler/Scigliano, Marketing-Management, p. 185. 


\subsubsection{Communication with the Financial, Investment and Press Communities}

Knowing and communicating the value of their brands can help companies generate positive public relations (PR) in financial markets which can, in turn, assist in boosting the share price. Such communication is independent from balance sheets and can be carried out by means such as company brochures.

\subsubsection{Assessment of Employee Bonuses}

Leading employees are usually compensated by a fixed monthly sum plus a variable profit share (bonus). Such boni constitute both important performance incentives and means of employee retention. In order to determine boni for employees working in brand-focussed divisions, their share in brandrelated profits needs to be calculated. This can be carried out by means of brand valuation.

\subsubsection{Brand Transactions}

Businesses are frequently re-organised through transactions in merger, acquisition $(\mathrm{M} \& \mathrm{~A})$ and liquidation cases. These include licencing deals with subgroups such as sale and licence back transactions. Failing to understand the value elements and implications in these activities can lead to undesirable outcomes such as acquisitions at prices which do not return expected benefits. Effective, comprehensive valuation can reveal important information which can be advantageously utilised in order to alter the transaction's nature and/or financial quid pro quo.

\subsubsection{Brand Transfer (M\&A, Outright Sale)}

As previously stated, brands are assets of central value for many businesses and often the most important and valuable ones. Therefore, apart from production facilities and customer relationships, they constitute, as a 'third pillar', ${ }^{254}$ an increasingly interesting target for potential acquirers. Hence, it is 
assumed that it is often the brands which are bought or targeted by corporate acquisitions and mergers; other assets are said to be of minor matter. ${ }^{255}$ Furthermore, knowing the value of their brands can enable companies to fend off hostile takeover bids. ${ }^{256}$ The fact that interrelations between brands and changes thereof owing to a corporate merger or acquisition are central value determinants is another issue specific to M\&A situations. ${ }^{257}$

In the course of corporate restructuring by means of brand-related M\&A deals, which are often multinational, the range of IP-related tasks does not stop at but is crucial for the audit and due diligence stages, in which the range, proprietor(s) and quality of title of existing IP rights are documented and all other existing assets, resources and liabilities are comprehensively scrutinised. A due diligence, which should be carried out in preparation of any $M \& A$ transaction, helps assess and manage risk and enables the initiator to implement best practices. For example, brands often need to be split (territorially and/or with respect to goods or services classes) between retained and disposed of businesses or between seller and acquirer, managed in a way which secures brand value, reputation and product or service quality and which balances competition law requirements with commercial objectives and secures desired brand strategic options.

A comprehensive brand and IP evaluation tool can be particularly helpful in an M\&A situation. Not only can it help to strengthen and focus the IP portfolio but also to manage and mitigate risks, show opportunities for utilisation of synergy effects, increase return on IP investment as well as awareness of IP importance within the acquiring company. This is not possible without capturing all characteristics of the respective brand in their entirety. For instance, high quality goods and services brands may find their value diminished if transferred to an organisation which does not sustain this potential. $^{258}$ The acquirer may not be aware of these issues prior to acquisition, and may expect the brand to continue providing the same pre-acquisition returns and benefits. Furthermore, a number of IP problems can be relatively

255 Friedhoff, Marken in der Übernahmeabwehr, p. 1. This is certainly true with respect to brand-focussed businesses and shall not belie the fact that patents may play a similarly important role, depending on the acquired company's asset portfolio and activities.

256 Cf. supra at 2.2.1 - RHM utilised brand valuation to ward off the takeover bid by Goodman Fielder Wattie.

257 Meissner, Science Factory 2004, 1, 2.

258 This is due to the general nontradable nature of intangible assets as explained above at 2.1.1.3.4. 
easily remedied or managed if detected early in the lifecycle of an enterprise but are much more expensive to fix at a later stage. ${ }^{259}$ Hence, comprehensive (e)valuation must be a necessary part of the transaction's due diligence.

Furthermore, the appraiser's expert opinion can be utilised for purposes of argumentation in the course of negotiations, be it for a deal limited to certain brands and associated assets or in the course of a sale of a complete business. Being well informed about the value of brands and other intangibles in the company by an independent third party can provide a stronger bargaining position in price negotiations. Value finding is the task of the valuator, yet pricing is a corporate decision. ${ }^{260}$

All this supposes that brands, including the IP right trade mark, are freely transferable. As of today, this applies to trade marks in all member states of the European Union. This has not always been so. In Germany, for example, the preceding rules to the present Trade Mark Act stipulated that every trade mark is accessory to the proprietor's business. ${ }^{261}$ Hence, a due transfer of a trade mark was not complete until the corresponding business had been transferred in whole or at least in the respective part. ${ }^{262}$

The Community Trade Mark Directive ${ }^{263}$ does not include rules or guidelines regarding transfer of trade mark rights. ${ }^{264}$ However, the later Community Trade Mark Regulation ${ }^{265}$ stipulates in Art. 17 (1) that a Community trade mark can be the object of a transfer, independently of an assignment of the associated business. According to Recital 10 of the same Regulation, a Community trade mark constitutes an "object of property which exists separately from the undertakings whose goods or services are designated by it". As a consequence, it is an asset which is capable of being transferred, charged as security and licenced. ${ }^{266}$ Either of these activities can take place

259 Limpert/Samiian, Conducting an Intellectual Property Audit and IP Due Diligence, p. 3.

260 Similarly, for cases of business purchase, Beisel/Klumpp, Der Unternehmenskauf, p. 49.

261 Warenzeichengesetz, in force until 1992, esp. § 8 (1).

262 Fezer, Markenrecht, $\S 27$ no. 7.

263 Fn. 108.

264 At the time of adoption of the Directive, the EU Member States were not able to reach agreement regarding a free transferability of trade marks, cf. Deutscher Bundestag, Gesetzentwurf der Bundesregierung - Entwurf eines Gesetzes über die Erstreckung von gewerblichen Schutzrechten (Erstreckungsgesetz - ErstrG), Bundestags-Drucksache 12/1399 of October 30, 1991, p. 69.

265 Fn. 108. 
between separate companies or within one enterprise or group. They can be with or without foreign and tax implications.

As Recital 10 of the Community Trade Mark Regulation further states, the possibility to transfer a trade mark exists "subject to the overriding need to prevent the public being misled as a result of the transfer". As a consequence, it can be demanded in some cases that the transferor of a trade mark keeps the possibility for quality control or confers with the mark certain goods or know-how (which would often be deemed to be part of the brand) in order to assure a certain level of quality of the branded goods or services.

\subsubsection{Licencing}

In the last two decades, trade mark and brand licencing has grown to a multibillion-euro business involving a wide range of industries, from fashion, the traditional licencing stronghold, to food and financial services. ${ }^{267}$

An IP licence is the right to use the respective intellectual property. It can be exclusive, i.e. granted to a single licensee only, ${ }^{268}$ or non-exclusive. Exclusivity can refer to specific parameters only, e.g. as geographic, temporal or distribution exclusivity. ${ }^{269}$ As the licensee compensates the licensor by payment of royalties in various forms (lump sum, ${ }^{270}$ milestone payments, running royalties, ${ }^{271}$ or a combination thereof), the value of the licence object, e.g. a brand, needs to be determined. Royalty rates are computed on the basis thereof.

266 The German Trade Mark Act has contained similar provisions since 1992, see $\S 27$ (1) and $\S 29$ (1) MarkenG (Gesetz über den Schutz von Marken und sonstigen Kennzeichen (Markengesetz - MarkenG) vom 25. Oktober 1994 (BGBl. I S. $3082(1995,156)$ ). According to $\S 31$ MarkenG, the right to a trade mark (i.e. the right to registration of the trade mark after application if all prerequisites are satisfied) can be used as credit collateral. For further reading, cf. Klawitter/Hombrecher, WM 2004, 1213, 1217.

267 Progoff/Palladino, Tips for successful trade mark licensing, p. 1.

268 Two types of exclusive licence need to be distinguished: the exclusive licence in the strict sense, in the course of which not even the licensor but solely the licensee is allowed to use the respective IP and the licensor merely retains formal title to the respective IP right, and the so-called 'sole licence', by means of which the licensor retains his use rights and licences out to merely one licensee, cf. Goddar, Deal-making, Understanding the Contractual Terms and Conditions for Licensing "out", p. 1.

269 More on the legal arrangement of licencing deals below at 5.13.1.

270 This is hardly found in brand licencing at all but in technology licencing, usually in cases where an exclusive licence is granted for the remaining term of a patent.

271 These are charged on a regular basis, for instance as actual percentage of sale revenue, a fixed monthly/quarterly payment or a sum per unit produced. 
Brand licencing can enhance brand value both directly (through increased sales volume and price premia) and indirectly (via increased brand awareness, which, in turn, can contribute to increased repurchase rates). It brings about various strategic and legal issues, pitfalls and opportunities.

With regard to brands, there are - next to relatively simple agreements regarding the trade mark only - a number of specific kinds of licencing agreements in use, depending on the underlying strategy. These include brand extensions, line extensions, ${ }^{272}$ promotional and hybrid licencing. Brand extensions are agreements whereby the brand is licenced for use on products or services similar to those of the brand owner. BMW automotive performance and design accessories are an example. Line extensions deal with products or services not similar to the brand owner's. Respective licencing agreements cover articles like Disney character dolls, Puma keychains, Burger King hats and so forth. Promotional licencing aims at advertising certain products in environments the producer would otherwise not have access to. For example, fast-food chains conclude such agreements with the movie industry on a regular basis. Hybrid licences combine the licencing of a technology, e.g. a patent, with the licencing of a brand. As mentioned above, licencing, instead of development of a new brand or product, is in many situations the means of choice since it, in general, consumes less resources such as time and money and is less fraught with risk. ${ }^{273}$

Franchises represent another circumstance where trade marks, along with a bundle of other rights and know-how, are licenced and thus necessarily valued. They are a special kind of licence with the peculiarity that a franchising agreement, in order to reach its objective of enabling the franchisee to act vis-à-vis the target audience as if he were the franchisor, provides for both comprehensive licences (including know-how) and a certain degree of goods transfer. ${ }^{274}$

272 As to brand and line extensions, cf. above at 2.1.2.2.2 with fn. 182 .

273 Cf. 2.2.1.

274 More on franchising below in fn. 812. 


\subsubsection{Bankruptcy}

In an insolvency situation, one of the insolvency administrator's ${ }^{275}$ duties is the exploitation of the estate. ${ }^{276}$ This can be done by means such as divestiture or licencing. In this connection, the IP right trade mark and the trade mark licence need to be distinguished.

Under German law, trade marks are part of the insolvency estate, as they are independently transferable property rights. ${ }^{277}$ For the same reason, licence rights can also be part of the insolvency estate. ${ }^{278}$ Each exploitation of a trade mark and/or a trade mark or brand licence, such as divestiture, needs a price tag for the respective object and therefore necessarily presupposes valuation. ${ }^{279}$

In order to achieve a result most favourable for the creditors, the insolvency administrator needs to understand and implement the highly unique contextual nature of trade marks and brands. Such assets may find their value diminished considerably if transferred to a business which does not or cannot sustain brand identity and image. Hence, the administrator will in many cases have to face the factual problem that there is no suitable acquirer for the brand. ${ }^{280}$ On the other hand, understanding the trade mark or brand's unique value and strategic potential (which can be facilitated by comprehensive (e)valuation) can open up more possibilities than initially envisaged.

\subsubsection{Brand Finance}

Although the use of intangible assets in finance is rather novel compared to use of tangible assets, utilisation of intellectual property rights such as patents

275 Contrary to German law, the UK, for example, knows a number of different denominations for what an 'Insolvenzverwalter' is in Germany. Depending on the type of procedure, one can distinguish administrators, liquidators, supervisors or receivers.

$276 \S 159$ InsO (Insolvenzordnung - German Insolvency Code).

277 BGH, judgment of 9 June 2004, Case I ZR 31/02, - Dorf MÜNSTERLAND II; Fezer, Markenrecht, $\S 29$ no.s 5 and 25; Steinbeck, NZG 1999, 133, 139.

278 Fezer, Markenrecht, $\S 29$ no. 27.

279 A recent example for the exploitation of a trade mark in a bankruptcy context was the sale of Michael Jackson's German 'MJ' monogram trade mark for $€ 85,000$ by means of an auction (cf. http://www.markenblog.de/?p=1351 - last accessed April 30, 2006). The amount will be used to settle monetary claims of TePax, an electronics company, vis-à-vis Michael Jackson and his German company MJ Net.Entertainment $A G$.

280 This is the issue of nontradability of intangibles, cf. supra at 2.1.1.3.4. 
has become a widely discussed matter in recent years. This development has not spared trade marks and brands. First IP-backed securitisations and collateralisations took place as early as in the 1990s. ${ }^{281}$

\subsubsection{Collateralisation for Financial Needs}

As trade marks, that is in Europe, are freely transferable assets, they can be used as credit collateral, at least in theory. The same applies to trade mark licencing rights and the position obtained through application for registration. In case the trade mark is registered thereinafter, the security right continues with regard to the registered right. ${ }^{282}$

In order to assess the extent to which a trade mark can secure a certain claim, it needs to be valued. This should be carried out as comprehensively as possible in order to obtain a holistic understanding of risks and opportunities associated with the respective trade mark.

The difficulties specific to using trade marks as collateral are not very much on the legal but rather on the factual side. The fact that trade mark rights can only unfold their maximum benefit and potential in combination with the other brand elements as well as other supporting tangible and intangible assets and as owned by a business which is willing and able to act accordingly considerably aggravates the bank's possibility to sell or otherwise exploit it promptly and for an adequate sum in case of default. ${ }^{283}$

\subsubsection{Credit Rating}

Another important issue with respect to loans is that banks have to look more closely than ever at credit users' risk, as required by the new so-called 'Basel II' rules issued by the Basel Committee on Banking Supervision in June 2004. These rules have revised standards governing the capital adequacy of internationally active banks. ${ }^{284}$

281 It is said that the first IP-backed securitisation was carried out in 1997, when musician David Bowie raised US $\$ 55$ million by securitising certain rights to future royalty payments arising from his music catalogue, cf. Medansky/Dalinka, Considering intellectual property securitisation. However, innovative IP-based financing began, at least in the US, as early as 1992, when Dow Chemical received a loan based on IP, cf. Hillery, Securitization of Intellectual Property: Recent Trends from the United States, p. 5.

282 Klawitter/Hombrecher, WM 2004, 1213, 1217/1218.

283 Q.v. 2.1.1.3.4 - nontradability. 
Prior to granting a loan, each bank passes through a rating process in which the debtor's solvency is being assessed. The debtor is being allocated to a certain probability of default. The worse the creditworthiness and the higher the probability of default, the more capital must be lodged by the credit institute. This means that cost of capital rises with falling solvency of the debtor. ${ }^{285}$ Basel II rules aim, amongst others, at enabling a risk assessment which is more detailed than it had previously been. ${ }^{286}$

Banks' rating will depend to a substantial extent on quantitative figures as laid down on the balance sheet. The value of the respective company's (acquired) brands can play an important role in this regard. Furthermore, comprehensive IP (e)valuation can help assess the creditworthiness of IP-focussed debtors. ${ }^{287}$ Debtor quality, in turn, is one of the factors to be considered during calculation of the lending bank's refinancing costs, which, in turn, is one of four elements making up the final cost of credit. ${ }^{288}$

\subsubsection{Securitisation}

Securitisation, or asset-backed securities, is a variety of corporate finance by means of which businesses turn receivables into cash. Hereby, the originator pools and sells certain assets (which presupposes their valuation) to a special purpose vehicle (SPV), a legal entity unconnected to the originator, which has been specially formed for this purpose. The SPV refinances itself by issuing securities. The cash flows generated by the sale are used by the originator to settle investors' receivables. ${ }^{289}$

Amongst others, securitisation can be based on revenues derived from intellectual property rights such as copyrights and trade marks. Securitisations utilising this type of asset are called 'operating-asset securitisations' as the originator is obliged to make these assets (contrary to fixed assets) work, i.e.

284 The full text has been issued by the Bank for International Settlements and is called "International Convergence of Capital Measurement and Capital Standards".

285 Schmeisser/Schmeisser, DStR 2005, 344, 344.

286 Volkenner/Walter, DStR 2004, 1399, 1399.

287 Quantitative factors such as operating cash flow influence the solvency assessment to a degree of approximately $60 \%$. The remaining $40 \%$ comprise qualitative factors such as market position, cf. Kudraß/Schäfer, BC 2003, 35, 36. Such factors would be assessed in the course of a valuation methodology as proposed in this work.

288 Schmeisser/Schmeisser, DStR 2005, 344, 344/345.

289 For more detailed information, e.g. on the role of the service agent, cf. Schmeisser/Leonhardt, DStR 2007, 169, 169. 
to actively exploit them. ${ }^{290}$ Even though the market for such securitisations is still small, a number of large IP-backed securitisations took place in the past indicating considerable market potential. In a 2003 landmark deal, Guess Jeans trade mark rights were securitised for US $\$ 75$ million. The American Dunkin' brands were, in 2006, securitised in the course of a US $\$ 1.7$ billion deal based on assets including royalty rights vis-à-vis franchisees. ${ }^{291}$

It is crucial for any IP-based securitisation to account for the fact that the respective rights have to be managed and exploited as easily as by the original proprietor. Therefore, the necessary valuation needs to include not only quantitative analyses but also qualitative ones, arriving at a comprehensive value statement taking not only purely financial risks and opportunities into account.

\subsubsection{Brand Protection}

Brand protection situations as reasons for brand valuation can be both future-related (protection strategy) and mainly historic (assessment of damages and of the amount in dispute).

\subsubsection{Brand Protection Strategy}

A brand protection strategy is a future-related management means which addresses the question how to best utilise trade mark law and other (legal and factual) regimes to protect the respective brand from infringement and genericide and from otherwise being watered down. As an issue of vital importance for survival and profitability of any business with brands, it should be part of overall brand management or at least closely intertwined with it.

A proper brand protection strategy has implications on various areas in the production and distribution cycles. For instance, secure packaging with barcodes, holographs, RFID tags ${ }^{292}$ and other technical protection means as well as careful selection of distribution channels are frequently used measures to prevent product piracy. Product packaging has become an integral part of

290 Sine autore (The Economist), Securitising Intellectual Property: Intangible Opportunities.

291 Mahmud, 17 Managing Intellectual Property, iss. 8, 22 (2006), 22 and 24.

292 Radio frequency identification (RFID) is the use of radio frequencies to read information at a distance on a small device, cf. Finkenzeller, RFID-Handbuch, p. 1. 
many businesses' brand protection strategy - not only since the packaging itself can be protected as a three-dimensional trade mark if the requirements are met ${ }^{293}$ but also because the packaging, by means of the abovementioned technical protection features, increasingly serves as an instrument to guarantee authenticity of the product along the entire distribution chain.

Next to such factual measures, legal means are also crucial elements of any brand protection strategy. These mainly include online and offline search for trade mark infringers and trade mark surveillance in order to prevent genericide. These law-related elements of a brand protection strategy will be dealt with in more detail below at 5.13.

In the brand protection strategy context, forecasting brand valuation, if carried out comprehensively, can be helpful for early detection and monitoring of possible factual and legal challenges as well as for singling out those brands for which investment (amongst others in the form of monitoring for protection strategy purposes) is expected to be profitable.

\subsubsection{Assessment of Damages and Amount in Dispute}

In trade mark cases brought before the courts, particularly in infringement and contractual disputes, legal dispute related valuations are generally carried out on the basis of past circumstances, for instance in context of assessment of damages, in which the aggrieved party, as a general rule, has to be put in a position as if the hurtful event would not have taken place. Furthermore, a trade mark-based amount in dispute needs to be determined in each case in which the main object of conflict is one or several trade mark rights.

Establishing the amount of brand value to be used in litigation is not a question of law but one of fact. As a consequence, since there is no room for legal argumentation in the area of fact finding, a specific fixed legal rule or practice relating to determination of brand value in litigation contexts cannot exist. Judges are therefore not bound by a certain valuation method or rule. ${ }^{294}$ Rather, trade mark or brand value, if needed, is established in the course of discovery or evidence stages of a legal proceeding.

293 As to three-dimensional marks cf. below at 5.2.3.2.

294 Cf., with respect to business valuation, BGH, judgment of 1 July 1982, Case IX ZR 34/81; Großfeld, Unternehmens- und Anteilsbewertung im Gesellschaftsrecht, p. 44. These business valuation statements are sometimes being adapted for IP valuation 
In general, damages for violation of intellectual property rights can be calculated according to the actually occurred damage (including lost profits), on the basis of profits made by the infringer or by way of licence analogy (how much would the proprietor have earned as a licensor during the time of infringement?). ${ }^{295}$ The amount of damages may only be calculated by means of one method whereby the plaintiff has the right to choose the method most favourable to him. ${ }^{296}$

The amount of damages specified by the plaintiff - or, if he has left it undetermined, by the court - merely reflects part of the value of an asset as it would be identified by means of a future-related strategic and comprehensive valuation tool. This is due to the circumstance that damages, whether assessed for a past and/or future event, merely refer to a limited time span in the life of the asset in question. Furthermore, an appraiser in a strategic valuation context would very likely utilise a licence analogy, but merely as a rough indicator of value. ${ }^{297}$

Hence, there is no room for comprehensive strategic forecasting valuations in the field of damages assessment; its purpose and the way it is carried out differs considerably from the purpose and procedure of damages calculation. This shall not belie the fact that determined damages reflect a certain value of the asset concerned. However, this value is merely related to utilisation of the asset in a limited time period (the time of infringement) and mirrors merely one aspect of a comprehensive forecasting value, such as profits derived directly from the asset.

without proper reasoning, cf. Reese, Die Bewertung von Immaterialgüterrechten, p. 30. However, it is possible to look at business valuation in this context due to the facts that a number of valuation tools are utilised for both purposes and that IP is an important part of all of a company's assets.

295 This threefold possibility of damages calculation had, in Germany, initially been developed by the courts, cf. e.g. BGH, judgment of 29 May 1962, Case I ZR 132/60 Dia-Rähmchen II; IIC 2002, 900 - Gemeinkostenanteil (with regard to patents and industrial designs respectively); BGH, judgment of 12 January 1966, Case Ib ZR 5/64 - Messmer-Tee II (for trade mark rights); Kraßer, GRUR Int. 1980, 259, 260; Schaub, GRUR 2005, 918, 919. With the 'Gesetz zur Verbesserung der Durchsetzung von Rechten des geistigen Eigentums vom 7. Juli 2008' (BGBl I p. 1191), in force since September 1, 2008, which mainly serves to implement Directive 20004/48/EC (Directive 2004/48/EC of the European Parliament and of the Council of 29 April 2004 on the enforcement of intellectual property rights, OJ L 157 of April 30, 2004, pp. 45-86), the German lawmaker codified this possibility in its specific IP laws, e.g. in $\S 14(6)$ MarkenG.

296 BGH, above fn. 295 - Dia-Rähmchen II.

297 Cf. below at 3.2.2.2.2. 
As far as the assessment of the amount in dispute is concerned, the amount as brought forward by the plaintiff is generally accepted by the courts. ${ }^{298}$ Cases in which this is challenged and an actual valuation has to take place are rare (strategic forecasting valuations could be utilised in this connection, but are probably of little practical relevance due to the fact that they are relatively elaborate compared to the purpose they are supposed to serve). For instance, the German Federal Supreme Court recently upheld the amount of $€ 50.000$ which is usually fixed by default. ${ }^{299}$ The court acknowledged the possibility of existence of particular circumstances justifying a higher or lower amount but denied them in that specific case.

It follows that comprehensive, quantitative and qualitative forecasting valuations are not needed for assessment of damages but could theoretically be utilised for assessing the amount in dispute (in Germany, one could use them to prove a certain value justifying a higher or lower amount in dispute than the default $€ 50.000)$.

\subsubsection{Accounting and Tax}

Valuation for accounting and tax purposes is imbedded in a framework of legal provisions, which are increasingly being internationally harmonised, especially in the accounting field.

Unlike future-related valuation for strategic purposes, accounting and tax valuations generally operate on the basis of circumstances bygone. The focus lies on documentation rather than on planning and strategy.

\subsubsection{Accounting}

Whenever an item appears on a balance sheet, it does so with a monetary figure. Hence, accounting necessarily presupposes valuation. The following paragraphs will give a brief overview of accounting rules relating to intangible assets as well as of possible implications thereof on the valuation of such assets.

298 Mayer/Kroiß, Rechtsanwaltsvergütungsgesetz, at no. 394.

299 BGH, judgment of 16 March 2006, Case I ZB 48/05. As to determination of attorney's fees in trade mark litigation, cf. BPatG, judgment of 7 December 2004, W (pat) 263/03. 
As a general rule, all assets making up a business are supposed to be readable off the balance sheet. Hereby, it is common practice in a number of jurisdictions to distinguish between tangible and intangible assets and - within the group of intangible assets - between internally developed and acquired ones.

Furthermore, internal, or management, and external accounting (also called financial accounting) need to be distinguished. In the course of internal accounting, which is utilised within the respective organisation to provide information to management, kind and scope of all asset valuation is at free discretion. This is not so with respect to external accounting, which is concerned with preparation of (publicly available) financial statements. The following paragraphs relate to external accounting only. ${ }^{300}$

\subsection{International}

Traditionally, intangible assets generally appeared on balance sheets solely in form of goodwill. In the course of the majority of acquisitions, the excess purchase price over the tangible assets' fair value had often been entirely allocated to goodwill. Assets such as patents and trade marks were therefore hidden behind the veil of goodwill as hidden reserves. Correspondingly, many businesses argued that intangible assets were neither measurable nor controllable. ${ }^{301}$

However, the International Financial Reporting Standards (IFRS) ${ }^{302}$ have

300 A concentrated overview of external accounting in the light of valuation will be given hereafter for reasons of clarity and completeness. Subsequently, accounting will not be addressed any more since this work is concerned with IP valuation for strategic purposes. For more information on accounting for intangible assets, in addition to the literature cited in the following, cf. e.g. Benker, Bewertung und Bilanzierung von Marken nach HGB, IAS und US-GAAP; Bentele, Immaterielle Vermögenswerte in der Unternehmensberichterstattung; Förster, Immaterielle Vermögenswerte nach IAS 38. Firmenwerte mit Zukunft und deren Behandlung nach IFRS; Greinert, Die bilanzielle Behandlung von Marken; Grüner, Behandlung der immateriellen Vermögenswerte im Rahmen der Erstkonsolidierung nach IAS/IFRS and Schütte, Aktivierungskonzepte immaterieller Vermögenswerte.

301 PricewaterhouseCoopers, Shedding light on IFRS: International Financial Reporting Standard 3 - The new Business Combinations standard, p. 2.

302 IFRS is a collection of international accounting standards for profit-oriented enterprises developed by private standard setters. It comprises the International Accounting Standards (IAS), which are issued by the International Accounting Standards Committee (IASC), the International Accounting Standards Board (IASB) standards as well as the interpretations by the International Financial Reporting Interpretations Committee (IFRIC) and those of the former Standing Interpretations Committee (SIC). The denotation 'IFRS' is used both as a generic term for all these accounting rules 
required all listed companies ${ }^{303}$ to report acquired intangible assets on their balance sheets, if their fair value ${ }^{304}$ can be measured reliably, from the year 2005. ${ }^{305}$

In detail, IFRS 3 and IAS 38 ("Intangible Assets") stipulate that all such assets need to be recognised and their fair value measured if they are identifiable (in order to distinguish them from goodwill) and controlled by an entity. ${ }^{306}$ In addition, there needs to be reliably measurable probable inflow of economic benefits, such as sales revenue. ${ }^{307}$

The identifiability criterion is met if the respective intellectual asset is separable (i.e. capable of being separated or divided from the entity and sold, transferred, licenced, rented or exchanged, either individually or together with a related contract, asset or liability) or arises from contractual or other legal rights (regardless of whether those rights are transferable or separable from the entity or from other rights and obligations). ${ }^{308}$

IFRS 3 includes an extensive list of intangible assets satisfying these criteria, which comprises trade marks, trade names, domain names as well as licencing, royalty and standstill agreements.

The mandatory recognition of acquired trade mark rights, separately from goodwill, makes these and other intangible assets more visible, improves their appreciation and consequently the status of those responsible for them. Additionally, intangible asset valuation for accounting purposes is of considerably increased importance. Positive communication of this will improve relationships with stakeholders, shareholders and investors which can help in the

and for a number of standards contained therein. The standards applicable to business combinations are IFRS 3.

303 Business entities which are not capital market oriented have the possibility to choose IFRS.

304 The term 'fair value' is not a uniform, separate term. Rather, it can be filled by other value terms such as market value, current or replacement costs, depending on the respective case, cf. Hüttche/von Brandis, Lexikon Rechnungslegung Bilanzanalyse Bilanzpolitik, p. 153.

305 This means from the transitional date on which the financial year 2005 starts - only for a few companies, a transition period until 2007 applies. Many large German corporations like e.g. Volkswagen $A G$ and Allianz $A G$ have already applied IFRS standards before 2005, cf. Accounting Standards Committee of Germany, FAQ (Frequently asked questions). According to $\S 292 \mathrm{a}$ HGB, this was allowed but not mandatory.

306 IAS 38.11 et seq. and IAS 38.13. A company exercises such control if it has the power to obtain the future economic benefit arising from the respective asset.

307 IAS 38.17.

308 IAS 38.12. 
generation of positive PR, procurement of funds and be reflected in the share price. ${ }^{309}$ Reporting certain intangible assets separately contributes to greater transparency in accounting, not only for business combinations.

According to IAS 38.24 in connection with IAS 38.65, intangible assets shall be measured initially at cost of acquisition or production. If an intangible asset is acquired in the course of a business combination, the cost of that asset is its fair value at the date of acquisition. Subsequent valuations shall be conducted using either the cost or the revaluation model. Utilising the former, the respective asset shall be carried at its cost less amortisation and impairment losses. The revaluation model provides for the intangible asset to be carried at a revalued amount. ${ }^{310}$

This shows that valuation for accounting purposes follows its own rules, focussing on defined values and accuracy. This is mainly necessitated by accounting prudence. The fact that a balance sheet does not fully reflect a company's value is, in return, tolerated. In consequence, there is no room for future-related comprehensive valuations as introduced in this work. ${ }^{311}$ Such valuations are by definition estimates and generally arrive at a value spread, not a fixed amount as it is required for accounting.

Now that acquired trade mark rights can be reported separately, it would seem logical to report internally generated ones as well. However, in the light of the factual circumstances and of valuation techniques currently in place it seems very unlikely that such rights can be valued reliably enough to satisfy international accounting standards. ${ }^{312}$ In the case of an internally generated brand, for example, it would be very difficult to allocate expenses to the specific corresponding trade mark. ${ }^{313}$ Hence, accounting for internally generated intangibles would open up possibilities of abuse. Accounting prudence, therefore, keeps standard setters and lawmakers from allowing such accounting practice. It is said that at least one market transaction serves to objectify the value sufficiently for balance sheet purposes yet without it uncertainty would be too dominating.

309 Caldwell, How IFRSs put brands on the balance sheet, pp. 2-3.

310 This revalued amount is the asset's fair value (to be assessed with reference to an active market, which means that this model is difficult to apply for intangible assets) at the date of revaluation less amortisation and impairment losses.

311 Cf. chapter four.

312 According to IAS 38.21, intangible assets' acquisition- or production cost needs to be reliably measurable.

313 Schmidbauer, DStR 2004, 1442, 1443. 
However, internally generated brands and intellectual property rights not separately appearing on the balance sheet can still be valued and referenced in publications such as the director's report or a so-called 'Intellectual Property Statement'. ${ }^{314}$ Such valuation would be part of strategic communication as mentioned above rather than of accounting.

\subsection{European Community}

By means of Regulation 1606/2002 (IAS-Regulation), ${ }^{315}$ the European Community has adopted IFRS for its jurisdiction. Art. 4 of this Regulation stipulates that companies the securities of which are traded on any stock market within the EC and which are subject to an EC jurisdiction are required to "prepare their consolidated accounts in conformity with the international accounting standards" for financial years starting on or after January 1st, 2005.

In addition, member states may permit or prescribe these publicly traded companies to prepare their annual accounts on the basis of IFRS as well and all other companies to utilise IFRS for the consolidated accounts and/or the annual accounts (Art. 5 IAS-Regulation). This provision aims to avoid fragmentation of applicable accounting rules in the light of harmonisation of the EC internal market.

\subsection{Germany}

On the basis of the IAS-Regulation, the German lawmaker has adapted national rules accordingly. ${ }^{316}$ Subject to $\S 315 \mathrm{a}(1) \mathrm{HGB},{ }^{317}$ all publicly traded parent companies are required to prepare their consolidated accounts according to IFRS. ${ }^{318}$ All other companies are allowed to choose IFRS for their consolidated accounts, $\S 315 \mathrm{a}(2)$ HGB. The traditional HGB rules will continue

314 Menninger/Kunowski, DStR 2003, 1180, 1182.

315 Regulation (EC) No 1606/2002 of the European Parliament and of the Council of 19 July 2002 on the application of international accounting standards, OJ L 243, September 11, 2002, pp. 1-4.

316 By way of the Gesetz zur Einführung internationaler Rechnungslegungsstandards und zur Sicherung der Qualität der Abschlussprüfung (Bilanzrechtsreformgesetz - BilReG), BGBl. I 2004, pp. 3166 et seq.

317 Handelsgesetzbuch - German Commercial Code.

$318 \S 315 \mathrm{a}(2)$ HGB stipulates similarly for parent companies which have applied for admission of shares to official trade. 
to apply for annual accounts for purposes of assessment of disbursements and tax. However, in addition to this, businesses have the possibility to create an individual financial statement according to IFRS rules, cf. § 325(2a) HGB.

\subsubsection{Tax}

The field of taxation has a number of different points of contact with IP valuation. These include disputes between corporate taxpayers and tax authorities regarding the extent of tax due (which is affected by the figures of assets appearing on the balance sheet, of which certain IP is part), tax planning strategies (e.g. investment holding companies, charitable donations) and tax regulation compliance, the most prominent subgroup of which is the issue of transfer pricing. ${ }^{319}$

\subsection{Transfer Pricing}

Transfer pricing refers to transactions across jurisdictional borders between related entities. These are usually entities under common control, e.g. companies part of one international group. ${ }^{320}$ Transactions falling into the realm of transfer pricing are not only cross-border delivery of goods, but also and particularly cross-border cost allocation, services and assignment or surrender of use of intangible assets. ${ }^{321}$ In fact, the arrangement of international transfer prices belongs to the economically most prominent tax law issues for multinational enterprises. ${ }^{322}$

319 Like accounting, taxation issues will not be dealt with in this work apart from the following paragraphs due to the fact that tax issues do not fall into the realm of valuation for strategic purposes as focussed on in this work. Apart from the sources cited below, more literature on IP valuation and taxation can be found at Bauer, Verrechnungspreise für immaterielle Wirtschaftsgüter des Anlagevermögens; Casley, Tax. Introduction to tax and IP; Dürrfeld/Wingendorf, IStR 2005, 464.; Herve/Stock/Bodenstein, BC 2005, 268; Hughes/Borzumato, 17 Managing Intellectual Property, iss. 8, 35 (2006) and Weber/Stoffels/Kleindienst, Internationale Verrechnungspreise im Konzern.

320 Dürrfeld/Wingendorf, IStR 2005, 464, 464.

321 Brügger/Streibel, Steuer Revue 2003, 598. The intra-concern assignment and surrender of use of intangible assets is becoming increasingly popular due to the fact that these instruments enable parent company and subsidiaries to strengthen their equity by unveiling hidden reserves (e.g. through an intra-concern sale of an internally generated brand), to use the respective IP by one or several units at a time, and other; cf. slides by Dr. Anke Nestler from May 19, 2006, accompanying her speech "Bewertung von Intellectual Property bei konzerninternen Übertragungen bzw. Nutzungsüberlassung" at the conference "Bewertung von IPRs" in Königswinter, Germany. 
Transfer pricing rules are applied in order to calculate the amount of profits which are liable to tax. These special rules are needed because in the case of transactions between related entities, the motivations for arriving at a certain price may be different from and not as balanced as two unrelated parties negotiating. For this reason, transfer pricing rules adjust the actual results to the results that would have occurred had the parties negotiated 'at arm's length'. 323

The arm's length principle is based on a comparison of the internal transfer price under scrutiny with a price independent third parties would have arrived at. This can be achieved either by comparison with agreements between two independent third parties conducted under the same or comparable conditions (so-called external comparison) or by comparison with agreements concluded by one of the dependent parties with one independent party, for example a licensee (so-called internal comparison). ${ }^{324}$ Finding such comparable agreements with regard to intellectual property assets is generally extremely difficult and sometimes impossible, because such transactions either do not exist (there is no comparable IP asset) or are rarely publicised (e.g. licencing agreements). ${ }^{325}$ The valuator needs to realise this and adjust his calculations accordingly.

There are a number of rules and guidelines on national and international levels which deal with this complex of issues. The OECD has issued transfer pricing guidelines ${ }^{326}$ which are - together with the American IRC sec. 482 rules $^{327}$ - the practically most important ones. ${ }^{328}$ Even though these rules do not concretely stipulate how the arm's length principle is to be operationalised, they lay down a number of methods by which an arm's length price can be calculated, such as the licence-based methods 'Comparable Un-

322 Ernst\&Y Young, 2005-2006 Global Transfer Pricing Surveys - Global Transfer Pricing Trends, Practices, and Analysis, November 2005, p. 4.

323 This arm's length principle is the foundation of all international rules on transfer prices, cf. ErnstEYYoung, Business Restructuring - Three Taxation Issues, p. 4.

324 Wurzer/Reinhardt, Bewertung technischer Schutzrechte. Praxis der Patentbewertung, p. 142.

325 Cf. 2.2.2.1.

326 Organisation for Economic Co-operation and Development (OECD), Transfer Pricing Guidelines for Multinational Enterprises and Tax Administrations. These guidelines are of such central importance that even some non-OECD member countries such as China and Chile orient by them.

327 The Internal Revenue Service (IRS) issues the Internal Revenue Code (IRC).

328 Wurzer/Reinhardt, Bewertung technischer Schutzrechte. Praxis der Patentbewertung, p. 142. 
controlled Transaction Method' (CUT) and 'Comparable Profits Method' (CPM). Sec. 482 stipulates that the method best arriving at such an outcome must be deployed (so-called 'Best Method Rule').

It follows that there exist a number of different methods of arriving at a transfer price meeting the requirements of the arm's length principle. Each of these involve (slightly) different methods of valuation but leave little room for comprehensive future-related valuations. The selection of the appropriate methods always depends on the facts of each case. ${ }^{329}$

\subsection{Corporate Succession}

A further relatively frequent valuation issue in the taxation context arises in cases in which a company needs to be duly passed on to the inheritor of the former owner's assets. Such a situation normally arises in the case of small to medium-sized companies owned by one person. ${ }^{330}$ In order to determine the amount of inheritance tax due, the complete company needs to be valued. Such a valuation regards all assets tangible and intangible, whether they are capitalised on the balance sheet or not.

In Germany, the Bewertungsgesetz ${ }^{331}$ contains valuation principles for the determination of tax and other public charges on the basis of the value of the respective asset as a whole. ${ }^{332}$ It is therefore of specific scope and not a body of law generally applicable for all valuations. ${ }^{333}$ However, the BewG merely contains general market value based norms and lacks rules on how a valuation in this specific tax context is to be carried out. ${ }^{334}$

329 These paragraphs introduce the basic concept of valuation for taxation purposes. For the objective of this study, it would be superfluous and divert from the intended structure if such issues were discussed in greater detail. The interested reader will find more information on these issues in the extensive contemporary literature, e.g. in Bauer, Verrechnungspreise für immaterielle Wirtschaftsgüter des Anlagevermögens and Weber/Stoffels/Kleindienst, Internationale Verrechnungspreise im Konzern.

330 Repenn/Weidenhiller, Markenbewertung und Markenverwertung, p. 30.

331 Bewertungsgesetz (BewG) in der Fassung der Bekanntmachung vom 1. Februar 1991 (BGBl. I p. 230), zuletzt geändert durch Art. 2 ErbschaftsteuerreformG vom 24. 12. 2008 (BGBl. I p. 3018).

$332 \S \S 1(1), 2(1)$ BewG.

333 Reese, Die Bewertung von Immaterialgüterrechten, p. 25.

$334 \S \S 9,10$ BewG. Inheritance Tax Guidelines ('Erbschaftsteuer-Richtlinien 2003 (ErbStR 2003)') are somewhat more concrete, especially in R 93, yet merely relate to inventions and copyrights. 


\subsubsection{Findings}

The fact that brands affect almost every section of a business is reflected in the many different reasons for brand valuation. Brand valuation is required, amongst others, in the course of strategic and operative brand management and controlling, brand transactions such as M\&A or licencing, brand finance and the proprietor's brand protection strategy (which can and should be treated as a subgroup of brand management). All of these situations have in common that, for the most part, future developments need to be estimated on the basis of presently available data (therefore, they cannot yield a fixed value outcome). Hence, they necessitate strategic future-related, or forecasting, valuations.

It follows that, due to the documentation-focussed nature of accounting and for reasons of accounting prudence, such forecasting valuations are neither suitable nor accepted for accounting purposes. Accounting, tax, finance ${ }^{335}$ and assessment of damages in litigation are application areas of historic (or reporting) valuations. These occasions have in common that IP valuation is focussed on documentation purposes and primarily carried out ex post (which means accurate, fixed end results can be determined). For some cases, there are rules which prescribe the use of certain valuation techniques.

\subsection{Summary and Conclusions}

The nature of the valuation object brand has been illustrated in this chapter. It has become clear that brands are, as intangible assets, complex phenomena going far beyond the concept of trade marks and trade mark law, which merely protects brand devices, i.e. signage such as logos, three-dimensional forms or sounds. Brands are bundles of benefits with certain characteristics which make sure that these bundles, from the point of view of relevant target audiences, strongly differentiate from other bundles of benefits meeting the same needs. They are personality-like phenomena consisting of an image

335 It is possible that both forecasting and reporting valuations can be utilised for brand finance purposes, the former providing a contextual comprehensively informative valuation and the latter a financial snap-shot of the respective asset's present or past, usually as documented on the balance sheet (for instance, in the course of a credit rating assessment). 
and an identity, part of which - the brand achievements - comprise signage elements which may be protectable by trade mark law.

Even though trade mark law can - for reasons of clarity and certainty - only speak of trade marks, the implications of its practical application usually affect the brand as a whole, as it relates to freedom to operate the brand. ${ }^{336}$

Due to their nature as intangible assets, brands bring about characteristics such as scalability and nontradability, which may have a positive or negative effect on their value. In addition, brands specifically reduce transaction cost and various risks, which needs to be taken into account if a truly comprehensive evaluation is desired. As brands depend on and affect many divisions of a company, they need to be taken care of and valued with a holistic view on all such corporate contexts.

Brand value can be defined as the estimated quantity of financial assets for which an item changes hands "on the date of valuation between a willing buyer and a willing seller in an arms-length transaction after proper marketing wherein the parties had each acted knowledgeably, prudently, and without compulsion". ${ }^{337}$ As such an ideal market situation cannot be obtained in practice, especially with regard to intangible assets, one should try to simulate it as closely as possible, especially by reduction of information asymmetries and of risks.

Brand management and controlling (including a brand protection strategy), brand transactions and finance (in part) involve and necessitate estimates of a future value based on present data. Therefore, brands need to be valued, in such circumstances, by a strategic forecasting tool.

Now that the foundations of a comprehensive, integrated understanding of brands and their value have been laid, it is expedient, as a next step, to analyse currently applied brand valuation techniques.

336 By contrast, rules of accounting for intellectual property speak of assets such as trade marks and patents (not brands) since they are, contrary to the brand as a whole, defined and transferable legal rights. From an accounting perspective, the brand elements going beyond the trade mark(s) would be allocated to goodwill. This is due to the fact that the law does not treat items such as brand identity or distribution channels as specific independent and transferable rights.

337 International Valuation Standards Committee, International Valuation Standards, p. 27. 



\section{Chapter 3}

\section{Brand Valuation - State of the Art}

This chapter provides both an overview of current brand valuation trends and issues and a discussion of brand valuation tools enjoying practical popularity at present.

The systematisation of brand valuation tools into groups as well as the merits and disadvantages of present brand valuation techniques set out in this chapter serve as reference points throughout this work in the course of the discussion of the issue how an ideal brand and IP valuation methodology should look like.

\subsection{The Current Brand Valuation Landscape}

Before attention will be turned to analysis of specific brand valuation approaches and methods, it is expedient to examine the brand valuation market as a whole. Hereby, the main emphasis will be put on the German market. Important general background information and issues will thus be worked out and illuminated.

\subsubsection{General Issues and Trends}

In many industry sectors, brands have become the central asset within companies' portfolios. With products and services often varying in mere nuances, it is the brands which ensure sufficient differentiation vis-à-vis competitors, build an important communication channel between buyer and seller and reduce risk, both on consumers' and proprietors' sides. 
As highly complex as they are, brands demand in-depth and well-informed management. Since one can only manage what one can (and actually do) value, valuation must play a central role for brand management decision makers. A lot has been achieved after first publications on brand valuation were made in the early 1960s. ${ }^{338}$ New brand valuation tools were developed, old ones improved. Since the first major deals relying on brand valuation were concluded in the $1980 \mathrm{~s},{ }^{339}$ the number of similar transactions has grown considerably.

However, even though the practical necessity of brand valuation has become generally accepted (and it seems to have been accepted earlier than in the patent field $\left.{ }^{340}\right)$, there exists considerable disagreement as to which factors drive and distract brand equity, what their functions and interrelations are in detail and how to manipulate these factors in one's favour.

This is mirrored by the fact that there are dozens, even hundreds of brand valuation methods available today. Brand consultancies, advertising agencies, consulting companies and market research institutes alike are trying to value and evaluate brands applying a plethora of different tools. According to a current study carried out by the German Institut für Markenwert (Institute for Brand Value), there are more than 300 such methods worldwide. ${ }^{341}$ In the German-speaking area, there are approximately 30 proprietary techniques on offer. ${ }^{342}$ Proprietary means that such methods have been developed companyinternally and are, in essence, not publicly accessible. Such methods have been created specifically for purposes of brand valuation. In addition, there are a number of generic, i.e. freely accessible and usable, approaches and techniques in place. Many of them, such as the cost approach, have been

338 See above, fn. 200 (Kern).

339 Cf. 2.2.1.

340 The first brand valuation literature was publicised in the early 1960s (cf. fn. 200) whereas valuation of patents was not beginning to be discussed until the 1990s. Cf. e.g. Smith/Parr, Valuation of intellectual property and intangible assets (1989); Simpson, Valuation of Scandinavian patent rights across industries, nationalities, and time: analysis, estimates, and applications (1992); Simensky, The new role of intellectual property in commercial transactions. Recent trends in the valuation, exploitation and protection of intellectual property (1994); Pitkethly, The Valuation of Patents: A review of patent valuation methods with consideration of option based methods and the potential for further research (1997).

341 Amirkhizi, "Suche nach der Weltformel". Q.v. Bentele/Buchele/Hoepfner/Liebert, Markenwert und Markenwertermittlung, p. 36, who have found a three-digit number of brand valuation approaches and models.

342 Schimansky, Markenbewertungsverfahren aus Sicht der Marketingpraxis, p. 15. 
used in other fields before they were adopted for brand valuation.

Even though a number of such (generic and proprietary) methods attain greater popularity than others, none of them seems to have reached widespread acceptance as best practice so far.

This is - amongst others - rooted in the dilemma that, while professionals wish to choose at least one of these tools for practical application, all of these methods, ceteris paribus, bring about clearly deviating valuation outcomes. For instance, the Volkswagen brand was valued by the brand consultancy Interbrand ${ }^{343}$ at $€ 7.6$ billion in 2002 whereas their competitor Semion $^{344}$ arrived at a value of $€ 18.8$ billion for the same brand at the same time ${ }^{345}$ which constitutes a difference of more than $140 \%$. A 2004 study carried out in Germany shows similar results. ${ }^{346}$ Nine companies offering brand valuation services were asked to value a fictitious petroleum industry brand. Even though all experts were provided with identical data sets, valuation outcomes varied between $€ 173.0$ million and $€ 957.9$ million, ${ }^{347}$ a difference of approximately $554 \%$. Such facts show that orientation in the thicket of brand valuation tools is intricate.

It is therefore hardly surprising that a considerable number of companies still do not perform valuations of their brands at all. A study by PricewaterhouseCoopers et al. has found that, in the year 2005, merely $38 \%$ of all surveyed companies had by then carried out non-monetary brand valuations and $23 \%$ had performed monetary valuations. ${ }^{348}$ Data collected by Günther and Kriegbaum-Kling in 1999 show similar results. As little as $37.2 \%$ of the surveyed brand-focussed companies had valued their brands (in a monetary and/or non-monetary way). ${ }^{349}$ This evidences that scepticism regarding monetary brand valuation methods has slightly decreased yet is still significant.

343 http://www.interbrand.com/home.asp (last accessed March 14, 2007).

344 Semion Brand-Broker GmbH; http://www.semion.com/ (last accessed March 14, 2007).

345 Perrey/Riesenbeck, akzente 2004, 2, 2. Both brand consultancies used their proprietary methods.

346 Hanser/Högl/Maul (ed.), Markenbewertung. Die Tank AG.

347 Ibid., p. 226. Both generic and proprietary techniques were used. Although most applied tools were proprietary, $K P M G$ used the incremental cash-flow, relief from royalty and multi-period excess earnings methods, all of which are generic tools based on the income approach.

348 PricewaterhouseCoopers/GfK/Sattler/Markenverband (ed.), Praxis von Markenbewertung und Markenmanagement in deutschen Unternehmen, pp. 17/18.

349 Cf. Günther/Kriegbaum-Kling, Schmalenbach Business Review 2001, 263, 278. 
A substantial part of all brand experts specify the fact that there is no suitable method for brand valuation as a main reason for this abstinence. ${ }^{350}$ Another paramount cause for refraining from brand valuation is the fact that such a valuation would be too time and/or cost intensive. ${ }^{351}$

Yet current literature shows that the belief in necessity and importance of brand valuation is undaunted. The abovementioned 2005 survey proves that - even though scepticism vis-à-vis current brand valuation tools is still strong - the majority of brand professionals is convinced of the importance of adequate valuation. ${ }^{352}$

Hence, despite the fact that most industry brand professionals have come to understand and appreciate that brand valuation is essential for a number of reasons, less than half of them actually perform such valuations. An implementation gap is slowly declining but still manifest.

The analyses following in this chapter will illuminate whether reasons having led to this gap are justified and if there are means to overcome it.

\subsubsection{Systematisation of Brand Valuation Methods}

As mentioned above, there are hundreds of brand valuation techniques available. Both practitioners and scholars divide them into groups in order to facilitate access to and understanding of the respective methodical information. More importantly, the analysis of some valuation techniques which will be performed later in this chapter can only be systematically carried out if the necessary degree of comparability between the discussed methods is reached. Such scrutiny therefore necessitates segmentation of methods into groups as a prerequisite for their analysis. Hence, the question how brand

350 PricewaterhouseCoopers/GfK/Sattler/Markenverband (ed.), Praxis von Markenbewertung und Markenmanagement in deutschen Unternehmen, p. 18, states that almost half of the surveyed experts saw this as a substantial reason for brand valuation abstinence (in 2005 - compared to $53 \%$ in the year 1999). Günther/Kriegbaum-Kling, Schmalenbach Business Review 2001, 263, 278 found that, in 2001, 36.7\% of the respondents claimed there exists no suitable brand valuation method, this being the principal reason for not carrying out brand valuations.

351 Günther/Kriegbaum-Kling, Schmalenbach Business Review 2001, 263, 278; PricewaterhouseCoopers/GfK/Sattler/Markenverband (ed.), Praxis von Markenbewertung und Markenmanagement in deutschen Unternehmen, p. 18.

352 PricewaterhouseCoopers/GfK/Sattler/Markenverband (ed.), Praxis von Markenbewertung und Markenmanagement in deutschen Unternehmen, p. 9. 
valuation methods can be expediently put in order needs to be answered at this point.

In theory, there are many different ways of systematic arrangement. A number of these can be found in current literature. For example, valuation models can be systematised according to disciplinary breadth, ${ }^{353}$ time perspective, ${ }^{354}$ process of value determination, degree of abstraction or process of data collection. ${ }^{355}$

However, a sustainable and acknowledged classification approach seems to be a categorisation on the basis of an assessment of the nature of input and output criteria or, in other words, the scientific discipline these criteria belong to. ${ }^{356}$ Such procedure leads to a subdivision into three classes of methods: financial, psychographic and hybrid (combining the first two) ones. This is the most persuasive modus operandi since input and output criteria are central to every valuation process. The employment of these criteria lets one arrive at a clear and focussed distinction of models which allows for their systematic comparison yet keeps the subgroups as broad and thereby as easy to comprehend as possible. Furthermore, such subdivision facilitates communication between valuation specialists and their clients since a partition according to scientific disciplines is easily comprehensible for valuation laypersons. For these reasons, this classification approach is both widely used in general and utilised here in particular.

Financial models are characterised by their focus on variables measured in financial units, both with respect to input and output parameters of value determination. Such models mainly process data derived from the respective company's internal auditing processes.

Psychographic (also named customer-related or behavioural) models focus

353 Irmscher, Markenwertmanagement. Aufbau und Erhalt von Markenwissen und vertrauen im Wettbewerb, p. 86 differentiates total ('Totalmodelle') and partial models ('Partialmodelle').

354 Sattler, ZfB 1995, 663.

355 Baumgarth, Markenpolitik. Markenwirkungen - Markenführung - Markencontrolling, p. 288, for instance, distinguishes compositional and decompositional brand valuation tools, the former being composed out of a multitude of single value factors, the latter starting with a global assessment which subsequently is being fractionised into individual components.

356 Similar to Jenner, Das Wirtschaftsstudium 2000, 945-951; Esch/Geus, Ansätze zur Messung des Markenwerts, pp. 1025-1057; Cheridito, Markenbewertung, pp. 946 et seq.; Meissner, Markenbewertung bei Mergers \& Acquisitions. Analyse und Konzeption am Beispiel der Pharmaindustrie, pp. 122-152. 
either on customer perception concepts or on criteria of buyer behaviour. Input data shows no financial dimension at all, nor is it being transformed into monetary parameters in the course of the valuation process. Such data is usually collected by specialised market research companies by means of customer surveys, customer observation or sales data analysis. ${ }^{357}$

Hybrid valuation models combine the two aforementioned methodical categories. Brand-related consumer behavioural factors are being detected and analysed. Output from such analysis is then combined with and/or related to economic parameters, such as estimated future income streams, in order to arrive at a brand value dimensioned in a monetary figure.

In each of these categories, generic and proprietary valuation tools can be distinguished. ${ }^{358}$ This is not a qualitative segmentation as the one in financial, psychographic and hybrid methods but rather a subdivision according to origin and degree of data accessibility. It plays an important role as background information, since it needs to be borne in mind that the lack of detailed information regarding proprietary methods impedes their analysis and verification. ${ }^{359}$

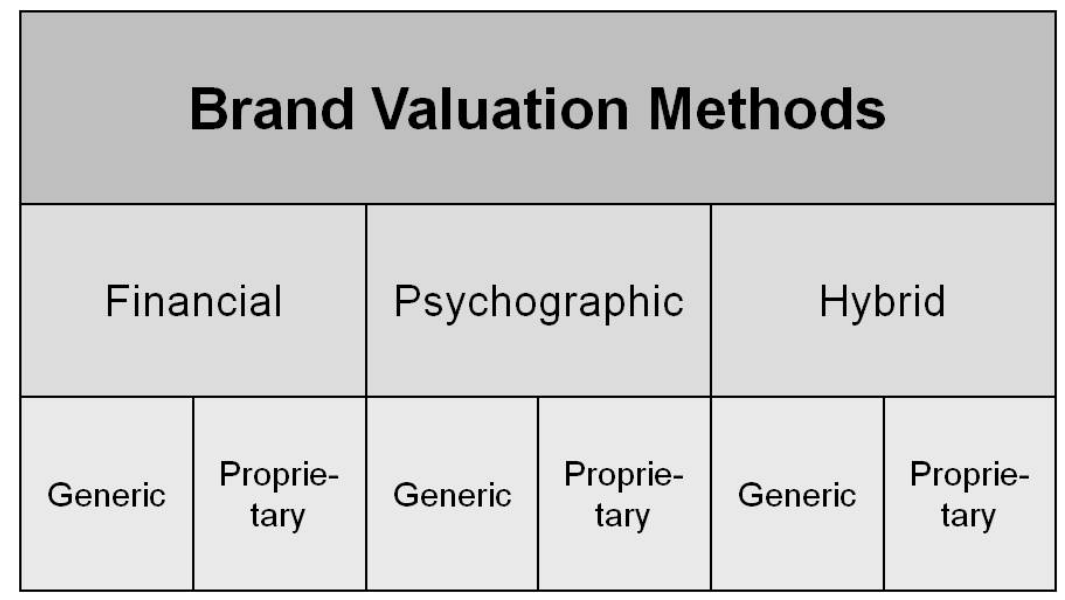

Figure 3.1: Brand valuation methods.

\subsubsection{Empirical Data on Distribution Rates: Surveys}

Having introduced three groups into which all brand valuation tools can be classified, it is expedient to take a closer look at these groups and the methods 
they comprise. The following paragraphs will therefore illuminate the practical popularity of specific brand valuation methods and the respective groups they belong to. This quantitative overview will be followed by a qualitative exemplary analysis of some valuation tools.

Retrieving data on the market share of specific brand valuation methods has proven intricate, especially with respect to the US and non-German European markets. However, a number of German surveys have been carried out in recent years dealing with - amongst others - the questions which brand valuation methods are being used in practice and how popular these methods are.

\subsubsection{Drees (1999)}

One of the early studies was conducted by Drees in $1999 .{ }^{360} 1,080$ brand experts were surveyed of which 190 individuals from all major industry sectors $^{361}(17.6 \%)$ returned completed questionnaires. Discounting the fact that a generic psychographic tool which is part of a number of proprietary methodologies achieved an awareness (and not an application) level of 50\%, ${ }^{362}$ merely four brand valuation methods achieved an awareness degree of over $30 \%$. These were the 'Brand Iceberg' model by Icon Added Value, 'BrandMonopolies' by Konzept \&3 Analyse, ACNielsen's 'Brand Balance Sheet' and 'Brand Character' by Grey. ${ }^{363}$ 'Brand Iceberg', 'BrandMonopolies' and 'Brand Character' are psychographic tools whereas 'Brand Balance Sheet' is hybrid.

360 Drees, Markenbewertung und Markenberatung in Deutschland - Ergebnisse einer empirischen Studie. As this work does not seem to be publicly available any more, all data on that study analysed in this work has been retrieved from secondary literature, which gives a good informative basis on the main conclusions of the study but does not reveal details on all possible valuation methods surveyed.

361 Fast moving consumer goods, durable consumer goods, services and producer's goods sectors.

362 This is the so-called Brand Essence Analysis (Markenkern-Analyse). Cf. sine autore, absatzwirtschaft 1999, 96. This method will be ignored in the course of this work as it attains little independent meaning due to the fact that it is included in a number of proprietary methodologies.

363 Ibid., p. 97. Cf. Baumgarth, Markenpolitik. Markenwirkungen - Markenführung - Markencontrolling, p. 299; Bentele/Buchele/Hoepfner/Liebert, Markenwert und Markenwertermittlung, p. 163. Icon Added Value and Konzept \& Analyse are brand consultancies, whereas ACNielsen is a market research company and Grey is essentially an advertising agency. Q.v. http://www.added-value.com, http://www.konzeptanalyse.de, http://www.acnielsen.de and http://www.grey.de (last accessed March 19, 2007). 
However, few of the surveyed experts had actually applied such methods. Solely $15 \%$ of the respondents had in fact worked with the 'Brand Iceberg' model, eight per cent with 'Brand Character', four per cent with 'BrandMonopolies' and none of them had deployed the 'Brand Balance Sheet' model. ${ }^{364}$

This means that the abovementioned psychographic and hybrid proprietary brand valuation methods were rarely used in German practice in and around the year 1999. It therefore has to be suspected that both proprietary financial and generic brand valuation tools of all three categories enjoyed a significantly higher degree of practical application. This is, however, an indirect conclusion since Drees does not seem to have (with one exception) queried distribution of generic methods.

\subsubsection{Günther and Kriegbaum-Kling (1999)}

This conclusion is being confirmed in part by the study penned by Günther and Kriegbaum-Kling, also carried out in 1999. The authors surveyed 1,016 German companies of which $13 \%$ replied with fully completed questionnaires. ${ }^{365}$

These companies clearly favoured generic financial brand valuation methods. By far the most widely applied (and not merely known) valuation method was the determination of brand related profit (40.3\% market share). ${ }^{366}$ The following four methods, applied by on average approximately $20 \%$ of the companies, were determination of brand related revenues per period (application rate of $23.9 \%$ ), of acquisition costs $(20.9 \%)$, of the price premium $(17.9 \%)$ and reference to brand values of comparable companies (17.9\% as well). The most popular hybrid valuation methodology, the one by $G f K,,^{367} 368$ was far behind on position five, being used by $14.9 \%$ of the companies.

For the sake of completeness, it needs to be mentioned that Günther and

364 Sine autore, absatzwirtschaft 1999, 96, 96; Bentele/Buchele/Hoepfner/Liebert, Markenwert und Markenwertermittlung, p. 164.

365 Günther/Kriegbaum-Kling, Schmalenbach Business Review 2001, 263. Even though this publication was made in the year 2001, the survey was carried out in 1999 (ibid., 267).

366 Sample size was 46 companies, multiple statements were possible, cf. Günther/Kriegbaum-Kling, Schmalenbach Business Review 2001, 263, 280.

367 GfK (Gesellschaft für Konsumforschung - Society for Consumption Research) is a market research company. Cf. http://www.gfk.com/group/index.de.html (last accessed March 19, 2007).

368 This tool is proprietary, since it has been developed by GfK. 
Kriegbaum-Kling focus on generic and proprietary brand valuation methods with a monetary outcome, hence on financial and hybrid ones. Psychographic tools are not considered at all. However, this omission does not necessarily render the collected data on the abovementioned monetary valuation methods useless.

It can be inferred from the results of Günther and Kriegbaum-Kling's study that, in and around the year 1999, generic financial brand valuation tools enjoyed far greater market shares than hybrid ones, which all seem to be proprietary.

Data concerning non-monetary valuation techniques can be used to complement these results. The question whether generic financial or other valuation methods were in fact the most widely used at that time can only be answered in synopsis with at least one additional study covering such other valuation methods.

\subsubsection{Schimansky et al. (2003)}

Looking at the survey carried out by Schimansky et al. in 2003, the strong focus on generic financial brand valuation techniques at first glance seems to have started shifting to psychographic and hybrid ones. ${ }^{369}$ However, it has to be noted that financial brand valuation methods are not mentioned in the survey. All generic and all financial (generic and proprietary) techniques do not seem to have been inquired at all. ${ }^{370}$ The results of the study therefore illuminate merely a fraction of the current state of the art of brand valuation, similar to works mentioned above.

Of around 2,000 surveyed German brand specialists, 344 returned completed questionnaires, which constitutes a return rate of $17.2 \%$. Similar to Drees' study, the experts were relatively evenly distributed amongst the fast moving consumer goods, durable consumer goods, services and producer's goods industry sectors.

Schimansky et al. differentiate between the degree of popularity of the entities offering the respective brand valuation tools, of the tools themselves and the

369 The survey itself does not seem to be publicly available as of March 2007, yet its main conclusions are presented by Schimansky, Markenbewertungsverfahren aus Sicht der Marketingpraxis, pp. 15 et seq. and Schimansky, marketingjournal 2003, 44.

370 Moreover, most financial tools are generic and most proprietary methods are either customer-related or hybrid. 
degree of actual application of these methods. A clear gradual decline can be identified between these three fields: whereas the most widely known provider of brand valuation services reaches a popularity degree of $69.2 \%$, the most popular brand valuation technique is known to $34 \%$ of brand experts and the most widely applied method reaches a level of merely $12.8 \%$ market share. ${ }^{371}$

The survey shows that hybrid valuation methods, despite the partially considerable degree to which they are being advertised, are still relatively rarely applied in practice. On average, merely two per cent of companies with brands actually use such methods. ${ }^{372}$

Of the 344 respondents, $12.8 \%$ had actually used the psychographic 'Brand Iceberg' model by Icon Added Value. The 'Genetic Code of the Brand' by Institut für Markentechnik, ${ }^{373}$ equally a psychographic method, ranks second with $6.7 \%$, followed by the hybrid Interbrand model reaching $6.1 \%$.

Looking at the relatively low market share of all surveyed proprietary psychographic and hybrid valuation methods, it can be inferred that the entirety of proprietary financial and all generic tools - of which financial ones are a major part - enjoys considerably more market share. ${ }^{374}$ Hence, a renunciation from financial brand valuation techniques cannot be verified.

As it is the case with respect to the abovementioned studies, more detailed conclusions can only be drawn in light of results from other studies.

\subsubsection{Völckner and Pirchegger (2004)}

An empirical study on the role of intangibles in German corporate practice was carried out by Völckner and Pirchegger in $2004 .^{375}$ The 1000 companies generating the highest turnover ${ }^{376}$ were queried and 119 completed questionnaires returned, which results in a return rate of $11.9 \%$.

371 Schimansky, marketingjournal 2003, 44, 45-48.

372 Ibid., at 49.

373 IFM - Institute for Brand Technology, a brand consultancy; cf. http://www.marken technik.ch (last accessed March 20, 2007).

374 Again, the question which methods in this entirety de facto enjoy the highest market share can only be answered in synopsis with at least one other study covering complementary data.

375 Völckner/Pirchegger, Immaterielle Werte in der internen und externen Berichterstattung deutscher Unternehmen - Eine empirische Bestandsaufnahme.

376 Based on the business year 2002. 
The authors, like those of earlier studies, distinguished high profile from the degree of actual utilisation of the valuation techniques. They found that, with $50 \%$ of the responsive companies carrying out brand valuations in regular intervals, two generic customer-related tools clearly held the highest average diffusion rate. Whereas $77.8 \%$ of the businesses examined single brand value indicators (such as brand image), $44.4 \%$ used a combination of several such indicators, which results in an average popularity rate of $61.1 \%$ of these two methods. $^{377}$

The following two most popular brand valuation techniques were found to be the calculation of historic cost, e.g. marketing cost and disbursements for development of the brand (50.0\% application rate), and capital- or income based methods (48.1\%). All these are generic financial methods and reach an average popularity of approx. 49.1\%. Techniques five to nine on the list fall in the same category; their diffusion rates vary between 42.6 and $11.1 \%$. Hybrid methods are not mentioned at all.

This is likely due to the circumstance that hybrid brand valuation techniques all seem to be proprietary. ${ }^{378}$ However, unlike Schimansky et al., Völckner and Pirchegger inquired generic brand valuation tools only. Their work therefore also deals with merely part of the overall brand valuation market yet provides a useful counterpart to Schimansky's study.

\subsubsection{Intermediate Findings}

Despite the fact that brand valuation has become a timely issue in modern management, no clear-cut outline of market share of valuation techniques can be obtained since none of the abovementioned studies comprehensively surveys generic and proprietary financial, customer-related and psychographic brand valuation tools. Those few surveys which have been carried out fail to provide fully representative outcomes. ${ }^{379}$ Varying between $11.9 \%$ and $17.6 \%$, the return rates of completed questionnaires are realistic but rather low. It also needs to be borne in mind that the studies introduced make statements

377 Völckner/Pirchegger, Immaterielle Werte in der internen und externen Berichterstattung deutscher Unternehmen - Eine empirische Bestandsaufnahme, pp. 19-20.

378 At all events, the author of the work at hand did not detect any hybrid generic brand valuation tools in the course of her rather extensive search for valuation methods.

379 This is in part being admitted by the authors themselves, cf. e.g. Schimansky, marketingjournal 2003, 44, 44. 
with respect to the German market only.

However, for the purpose of this part of the study - obtaining an overview of what kind of brand valuation methods were recently and are currently most widely applied - the studies provide a sufficient informative basis in order to at least work out general preferences and practical application trends.

Both the studies by Drees and Günther/Kriegbaum-Kling were carried out in 1999. The former deals with proprietary tools (with one exception, the Brand Essence Analysis, which is a generic tool incorporated in many proprietary methodologies ${ }^{380}$ ) whereas the latter focuses on both proprietary and generic financial and hybrid methods. Read together, the two works provide an almost complete picture, with merely generic customer-related methodologies missing. With all due caution in respect of the statistical significance of their outcomes, the studies nevertheless indicate a clear preference of generic financial valuation tools (market share of up to about 40\%), such as the determination of brand related profit or revenue and of acquisition costs of the relevant brand. Hybrid and psychographic methodologies, both proprietary, attained market shares of roughly $15 \%$ and lower. Market shares of proprietary financial methods were extremely low. Generic hybrid tools seem not to exist.

The data sets provided by the Völckner/Pirchegger study, which focus on generic brand valuation methods only, and those made available by Schimansky et al., which deal exclusively with proprietary tools, can be read in synopsis in order to attain an indication of recent (2003/2004) trends for financial, customer-related and hybrid models. The instance that Völckner/Pirchegger make no mention of hybrid methods (but of financial and customer-related techniques) reflects the fact that there seem to be no generic hybrid brand valuation methods available. Similarly, Schimansky et al. itemise no financial techniques which goes in line with the circumstance that there are a number of proprietary financial valuation tools ${ }^{381}$ which, however, attain little or zero market share, that is in Germany.

Like the 1999 surveys, the 2003/2004 studies prove a stable trend of popularity of generic financial brand valuation methods (market share of up to $50 \%$ ). In addition, sufficient data was available to prove that generic psycho-

380 For this reason, it is ignored in the course of the analysis at hand.

381 Such as the Pricing Model by Blackston, the licence-based brand valuation by Consor or WoReWert@ by Repenn. 
graphic techniques enjoy strong market shares as well. ${ }^{382}$ The most popular of such methods reached an application rate of $77.8 \%$. However, even though a number of providers of proprietary brand valuation tools are known to many brand experts and some such techniques have been newly developed, they have not gained market share compared to $1999 .{ }^{383}$

In the area of financial brand valuation tools, the income approach in its pure form seems to be the most widely applied brand valuation technique, being split up into calculations of brand related profit per period (distribution rate of $40.3 \%$ ) and brand related revenues per period (distribution rate of $23.9 \%$ ). These figures relate to the income approach in its simplest form, notably without computing the net present value of future profit or revenue streams respectively. ${ }^{384}$

Simple generic psychographic tools also hold considerable market share. Völckner/Pirchegger have shown that the examination of single brand value indicators such as brand image is being utilised by almost $80 \%$ of the queried experts. The combination of brand value indicators reaches a significant market share of $44.4 \%$.

With both generic financial and generic psychographic tools reaching such high market share, which would in sum be more than 100\%, it follows that a number of respondents are using both kinds of techniques. This may be due to the instance that a number of brand experts deploy more than one brand valuation method in order to minimise the spread of deviating outcomes in one and the same valuation scenario. Moreover, the assumption that financial and psychographic valuation techniques are used for different purposes stands to reason.

Hybrid tools, of which all those discussed in the surveys are proprietary, are still struggling to catch up with the abovementioned generic ones. In this context, the past and current lack of confidence in available valuation methods becomes most apparent. To a considerable extent, this may be due to the fact that these techniques, in their essence and core aspects, are not being revealed to the interested public at large, as it is the case with generic

382 This fills the information gap the 1999 studies had left.

383 The most widely applied psychographic proprietary tool reached an application rate of $12.8 \%$ and the accordant hybrid methodology attained $6.1 \%$.

384 Such particular methods including discounted cash flow analysis arriving at a net present value attain distribution rates of $13.4 \%$ (relating to forecasted brand related revenues) and $10.4 \%$ respectively (with respect to forecasted brand related profits). 
tools. As a consequence, proprietary methods cannot be fully understood and proven. The reluctance to apply such methods may also be rooted in the fact that they all have been developed specifically for brand valuation and have not become familiar tools in the course of other valuation scenarios, such as the income approach which was used for company valuations before it was adopted for the valuation of brands and other intangible assets.

\subsubsection{Findings}

Even though the necessity and benefit of brand valuation is widely recognised, the extent of practical implementation falls short of its importance - despite a slight upward trend.

An exception hereof can only be made with respect to some generic psychographic valuation methods, which reach largest market shares of all three groups (financial, psychographic and hybrid techniques). However, due to the fact that such methods do not yield a monetary valuation end result, they are only useful for a limited number of strategic forecasting valuation purposes. ${ }^{385}$

As for financial and hybrid methods, the implementation gap takes full effect. This is not only detrimental for the brand valuation industry. It also means that brands are oftentimes not valued at all. This brings about negative implications on many company internal and external processes. It is not until a brand is properly valued (with a monetary end result) that it can be appropriately managed, traded and otherwise exploited as an asset.

Those who, despite all current shortcomings, actually have their brands valued, rely to the largest extent on freely available methods of which many have been adopted for brand valuation from other fields of practice. Generic financial methods such as the income approach and its variations and generic customer-related ones such as evaluation of brand value indicators hold the largest market shares.

A possible added benefit proprietary methods provide vis-à-vis generic ones has not yet been reflected by their market share. The following analysis will, among others, discuss whether this circumstance rightly exists. 


\subsection{Analysis of Currently Applied Brand Valuation Methods}

In order to see whether the present retentiveness vis-à-vis actual performance of brand valuation is justified and, if yes, to elaborate what could be improved and how, some of the currently applied brand valuation methods will be analysed in the following.

\subsubsection{Introduction}

For these purposes, an exhaustive treatment of all available or commercially applied brand valuation routines needs not be carried out. It has already been provided by a number of other studies. ${ }^{386}$ More importantly, such broad overview would not add extra value in light of the purposes of this work. ${ }^{387}$ Keeping in mind that this contribution is aiming at, amongst others, illuminating fundamental coherences of brands and their value, providing both an analysis of the vital issues common to all brand valuation tools and an exemplary analysis of methods currently most popular in German and European practice in order to set out general trends and issues is both sufficient and expedient.

\subsubsection{Selection Criteria}

Two to three brand valuation methods in each category of techniques (financial, customer-related and hybrid) will be presented and analysed. Such exemplary approach will be used to illuminate positive and negative aspects characteristic to each class of models.

The methods' selection is based on both their practical significance and their degree of elaboration.

386 Bentele/Buchele/Hoepfner/Liebert, Markenwert und Markenwertermittlung; Esch/Geus, Ansätze zur Messung des Markenwerts; Frahm, Markenbewertung. Ein empirischer Vergleich von Bewertungsmethoden und Markenwertindikatoren; Hanser/Högl/Maul (ed.), Markenbewertung. Die Tank AG; Künzel, Die Marke und ihr Wert; Sattler, Markenbewertung: State of the Art; Schimansky (ed.), Der Wert der Marke; Zednik/Strebinger, Marken-Modelle der Praxis. Darstellung, Analyse und kritische Würdigung; Zimmermann/Klein-Bölting/Sander/Murad-Aga, Brand Equity Excellence, Volume 1: Brand Equity Review, pp. 31 et seq.

387 As defined at 1.1.1. 


\subsection{Practical Significance}

Since the author's systematic integrated methodology which will be introduced in the following chapter is a brand (and IP) valuation methodology specifically created for practical application, it is reasonable to choose methods currently applied in practice in order to reach a maximum degree of comparability. Therefore, methods which are being applied relatively often have been selected for scrutiny hereafter.

In this connection, the abovementioned surveys were relied upon for guidance. Even though they are not fully representative, they provide a useful overview of past and current practical brand valuation trends. Groups of relatively popular valuation methods can thus be separated from methods rarely mentioned and applied. The most popular tools in each category are candidates for closer scrutiny.

\subsection{Sufficient Elaboration}

Out of these groups, only those valuation techniques can be analysed in detail with respect to which enough data is available.

Every scholar and practitioner analysing brand valuation methods (other than internally developed ones) faces the problem of data shortage. This is due to the fact that such analysis is and can only be based on publicly available information. The crux of the matter is that, in consequence, proprietary valuation models cannot be examined in all their facets. Therefore, every analysis is necessarily skewed to some degree. However, it is comprehensible that the inner life of such methods is not completely revealed since they are applied by practitioners for a living and therefore need to constitute a business secret to some extent. For our purposes, this situation has given rise to a selection of not only practically significant but also relatively well documented methods for assessment. Hereby, the problem of data shortage is being mitigated to an acceptable degree.

\subsubsection{Assessment Criteria}

A number of criteria a future-related valuation method should meet and needs not meet respectively have been elaborated in chapter one. ${ }^{388}$ In consequence, 
these criteria need to and will be used in this chapter to scrutinise currently applied brand valuation tools, as well as in chapter four to examine the newly introduced methodology.

\subsubsection{Financial Techniques}

Financial brand valuation methods hold an exceptional position since one needs to distinguish the general valuation approaches they are based on from the many generic and proprietary methodologies which have been developed from these approaches. Therefore, the three existing basic approaches will be introduced prior to an exemplary analysis of three specific derivative methods.

At this point, it is important to note the difference between an approach, a methodology and a method. An approach describes a way of solving a problem or addressing an issue in general or preliminary terms. ${ }^{389}$ It may serve as a conceptual basis for a number of methodologies and methods, ${ }^{390}$ which present specific and detailed procedures and techniques of problem solving. Approaches therefore need to be discussed before attention is focussed on methodologies and methods. Whereas a method constitutes a technique for doing something, a methodology consists of more than one such methods.

\subsubsection{The General Approaches}

The three basic financial approaches to valuation are cost, market and income approach. They have been used for all assets, including IP, over circa the past twenty years and form the basis of almost all ${ }^{391}$ the many financial valuation

388 At 1.4 .

389 According to the Merriam-Webster Online Dictionary, an approach is "the taking of preliminary steps toward a particular purpose". Oxford Advanced Learner's Dictionary defines an approach as (amongst others) a "way of dealing with a person or thing".

390 The Merriam-Webster Online Dictionary defines a method as "a procedure or process for attaining an object: as [...] a way, technique, or process of or for doing something" and a methodology as "a body of methods, rules, and postulates employed by a discipline: a particular procedure or set of procedures". According to Oxford Advanced Learner's Dictionary, a methodology is a "set of methods used" and method as a "way (of doing sth.)".

391 Except a small number of financial market oriented methodologies such as the 'Stock Market Model' by Simon/Sullivan, cf. Simon/Sullivan, 12 Marketing Science, iss. 1, 28 (winter 1993). These techniques could be subsumed under 'market based methods' yet hold a somewhat exceptional position since they are not based on a market value 
methods and methodologies currently in place. Particularly one of them, the income approach, is widely used both in its original form and as a basis for specific generic and proprietary valuation methods. ${ }^{392}$

The three basic approaches originate from valuation of tangible assets, especially of companies, ${ }^{393}$ yet have found their way into intangible asset valuation which entails a number of particular problems and issues.

\subsection{Cost Approach}

The cost approach is based on the assumption that value of an asset is reflected by the monetary cost incurred acquiring or producing it.

Using the cost approach, it has to be asked what the historic cost ${ }^{394}$ of the brand under valuation is, i.e. sunk cost ${ }^{395}$ caused directly by the brand in question up to the time of valuation such as cost for development and registration of the trade mark, marketing etc. This cost approach in its basic form functions solely with historic data. ${ }^{396}$

There are two variations of this basic form of the cost approach which function with current instead of historic data. One is operating with replacement cost, the other with reproduction cost. Replacement cost is the cost it would take to obtain a similar asset with equivalent utility at the time of valuation.

of the respective brand but of the company as a whole, from which brand value is derived. As such methodologies can only be applied on stock exchange listed firms and hardly play any practical role in Europe and Germany, they are not discussed in this work. However, issues pertaining to the market approach as discussed below also apply to stock market based tools.

392 A number of publications, especially from the 1990s (e.g. Smith, Trademark Valuation (1997)), solely discuss cost, market and income approach with some derivative methods of the latter like the relief from royalty or discounted cash flow methods. It seems that the development of hybrid (financial-psychographic) brand valuation methods did not gain ground considerably before circa the turn of the millennium.

393 Ballwieser, Unternehmensbewertung - Prozeß, Methoden und Probleme, pp. 8-11; Franzen, DStR 1994, 1625, 1626 et seq., Esch/Geus, Ansätze zur Messung des Markenwerts, p. 1281.

394 This is also called trended cost, see Anson/Suchy, Fundamentals of Intellectual Property Valuation: A Primer for Identifying and Determining Value, p. 65.

395 Sunk costs are fixed, i.e. one-time, past expenditures which are unrecoverable, regardless of future events, cf. Silbiger, The 10-Day MBA, p. 51.

396 The lion's share of all historic cost relating to brands does not arise before the trade mark is actually registered but in the time after grant. It is not the expenses necessary to get the trade mark registered and the signage developed etc. but the brand management cost, i.e. expenses for building, developing and maintaining the brand image (such as advertising) and for keeping the trade mark alive that account for the major share in overall cost accruing from a brand. 
Reproduction cost is the cost one would have to spend to duplicate, or recreate, the asset today. The duplication would have to be an exact replica of the asset.

An advantage of the basic, historic form of the cost approach is the fact that it is, in general, relatively easy to handle since most cost factors will be known within the respective firm, at least in cases of one brand being allocated to one product. ${ }^{397}$ Even in this context, however, the multitude of items which would ideally have to be included in such a calculation, especially with respect to large brand development or R\&D projects, makes it very difficult to arrive at 'true' costs. ${ }^{398}$

Computing replacement or reproduction cost of intellectual property assets generally faces more difficulties than of tangible, especially mass-produced, goods. Replacement and reproduction cost of tangible goods can in many cases be assessed using market data in case internal data collection does not yield adequate results. ${ }^{399}$ Due to their typically unique character, obtaining a similar IP asset with equivalent utility is hardly possible. As IP assets are highly contextual, assessing all factors which would play a role in their fictitious duplication or recreation would involve considerably more guesswork than with respect to many types of tangible assets such as fast moving consumer goods (the reproduction cost of which is relatively well documented).

The biggest question mark regarding the cost approach, however, is the issue of how valid the link between cost and value of an asset in fact is. The cost approach functions by totalling financial resources which were used to build and develop the asset. One could at best say that these sums reflect a value the asset had for the proprietor in foretime while spending these sums of money. The cost approach therefore is exclusively focussed on the past and consequently does not give a valid indication as to a present or future value. A company may have spent millions of Euros on research and development for

397 As mentioned above, problems may arise in case of corporate brands or in situations where the item of expenditure is of such general nature that only part of it is attributable to the brand in question. In this latter case, the brand specific cost would have to be separated from overall cost. This process would be likely to entail considerable difficulties.

398 Cf. Razgaitis, Valuation and Pricing of Technology-Based Intellectual Property, p. 51.

399 The underlying critical difference of tangible and intangible asset is - as explained at 2.1.1.3.4 - the fact that tangible assets are in general characterised by marketability whereas intangible assets such as intellectual property fail to be traded on publicly accessible markets. 
a pharmaceutical patent or the development of a brand in the past, deeming the invention or brand valuable at that time, hoping for big potential, success in clinical trials, a huge market for the patented and branded products and so forth. In case the project turns out to be unsuccessful or to underperform, the respective patent or brand can nevertheless only be worth nothing or merely little today due to the absence of a (fruitful) possibility to exploit it. However, a valuation using the cost approach would nonetheless give it an expensive price tag. Should the plans be crowned with success, the proprietor would be very unskilful if he valued the respective assets merely at their cost level, as they would yield considerable return on investment. ${ }^{400}$

In addition, with respect to brands in particular, the cost approach is inherently unsuitable due to the fact that it does not allow for operationalisation of future success potential of the scrutinised brands through strategic options such as brand extensions, which is a significant factor contributing to their utility and therefore to their value. ${ }^{401}$

Hence, the cost approach is suitable in cases of past-oriented situations of valuation. These are, in particular, accounting and other reporting purposes as well as tax functions. With respect to future-oriented strategic valuations this work is dealing with, ${ }^{402}$ cost has very little to do with the actual value of an asset. In some instances, the cost approach could be used as no more than a rough indicator of value ${ }^{403}$ if obsolescence factors are accounted for ${ }^{404}$ yet in general the cost approach is not suitable at all for future-oriented valuations.

\subsection{Market Approach}

Valuation using the market approach is carried out by finding transactions regarding equivalent assets in markets same or equivalent to those of the asset to be valued. Market value can be defined as the estimated amount for which an asset should exchange on the date of valuation between a willing buyer and a willing seller in an arm's length transaction (after proper marketing and wherein the parties had each acted knowledgeably, prudently and without

400 Razgaitis, Valuation and Pricing of Technology-Based Intellectual Property, p. 49.

401 Sattler/Högl/Hupp, Evaluation of the financial value of brands, p. 11.

402 See above, 1.2.

403 For example as an upper limit of value, cf. King, Valuation, p. 75.

404 Such factors include deterioration (physical and otherwise), legal, functional, economic and technological obsolescence. 
compulsion) ${ }^{405}$ In order to arrive at such a value, the appraiser will have to compare market data on assets akin to the one under scrutiny. Hence, an active, sufficiently transparent market with at least a few comparable arm's length transactions is needed to arrive at a workable value figure.

In case such data is provided, for example with respect to shares publicly traded on the stock market, the market approach can provide solid valuation outcomes since the monetary figure for which two parties are willing to exchange an object is a proper materialisation of the utility the asset brings about for either side and therefore of its value. This is why the market concept of value is the most common type of value associated with tangible property. ${ }^{406}$

Here lies the crux of this approach: Only regarding a number of tangible or financial assets, e.g. real property, fast moving consumer goods or publicly traded stocks, will there ever be enough transparent transactions to bring this approach to a reasonable application. For intellectual property assets themselves, ${ }^{407}$ this approach is almost completely unemployable. Intangible assets are not traded frequently enough to provide useable data. ${ }^{408}$ In cases such transactions take place, details are usually kept secret, with the result that no open markets exist. What is more, even if information regarding such transaction was revealed, the fact that intellectual property rights and assets are inherently unique (to varying degrees) impedes their theoretical comparability in a market situation.

One could at best use licensing data, ${ }^{409}$ bearing in mind that there is no such thing as exactly comparable licensing information, especially with regard to intellectual property assets. The reason for this is that intellectual property assets are inherently contextual and unique. One would hardly ever be able to find two comparable intangible assets ${ }^{410}$ let alone licensing information

405 International Valuation Standards Committee, International Valuation Standards, p. 27.

406 Ibid., p. 26.

407 And not the tangible goods related to them, such as branded products, goods manufactured using patented technology or tangible media of expression on which copyrighted content is fixed such as books.

408 Cf. 2.1.1.3.4.

409 This is called the 'licensing analogy' approach which will be discussed below at 3.2.2.2.2.

410 This applies especially to brands since their degree of utility is highly dependent on the proprietor. The situation is slightly less precarious with respect to patents, yet the basic problem remains the same. 
with respect to such assets.

Furthermore, a transaction price, whether derived from an outright sale or a licence, does not necessarily reflect the value of the respective asset. The proprietor may, for instance, be inclined to give the contractual partner a better deal than he would give other potential parties due to personal or business strategic objectives. In addition, special warranties or indemnities may have been included in the contract or tax considerations may have played a role in setting the payment size. It follows that the numerous available publications on royalty rates generally applied in certain industry branches ${ }^{411}$ must be treated with caution. Relying exclusively on such information would entail considerable danger of misevaluation of the asset. Furthermore, inclusion in such a publication of data regarding a transaction for which information from such a list has been used could in turn perpetuate the abovementioned shortcomings throughout the respective industry.

Hence, the only case in which the market approach may work with respect to an intellectual property asset is a resale or repeated licensing of a previously sold or licensed asset, in temporal proximity to the previous sale or licensing deal and under similar circumstances.

\subsection{Income Approach, Discounted Cash Flow and Decision Tree} Analysis

The income approach focuses on future benefit the proprietor is able to derive directly from the asset in question. According to this approach, the sum of all future income streams derived exclusively from the asset equals its value. Preor post-tax income usually function as income measures. ${ }^{412}$ Unlike the cost approach which takes historic data to arrive at a value, the income approach works with estimated future parameters to calculate future financial benefit. The income approach is very popular in practice because estimated future income streams are felt to reflect the intrinsic value of an IP asset much

411 See for example Groß, WRP 2003, 1199; Battersby/Grimes, Licensing Royalty Rates and online services (subject to a charge) such as Royaltystat (http://www.royaltys tat.com/ - last accessed January 25, 2007), Royaltysource (http://www.royaltysou rce.com/royaltyrates.html - last accessed January 25, 2007) and KnowledgeExpress (http://www.knowledgeexpress.com/ - last accessed January 25, 2007).

412 International Valuation Standards Committee, International Valuation Standards, p. 191. 
better than a historic look at expenditures made with respect to the asset in the past.

Even though this approach therefore bears the potential to be viable for strategic valuations, there is a number of problems associated with it. The circumstance that the income approach seeks to arrive at a monetary figure reflecting all future income streams derived from the IP asset in question implicates that the valuator is tasked with separating this exclusive income stream from all other income streams, primarily from the income stream associated with the branded good or service itself. In case of brand valuation, for example, the appraiser must separate the earnings which are attributable to the respective brand only (this will largely be sales earnings) from the remaining overall earnings of the business. This is an issue especially pertinent to intellectual property and other intangible assets, since such assets, in most scenarios, only generate cash flows in combination with other assets. For instance, a pharmaceutical patent can, through product sales, generate cash flow and income in combination with the machinery used to produce the respective pharmaceutical product or a brand can do similarly in combination with a branded product. On application of the income approach to a brand, one needs to look at the extra value brought about by the brand only, the so-called brand-specific earnings. ${ }^{413}$ The dependence on other assets for cash flow generation often makes the isolation of these figures very demanding, if not impossible.

Moreover, the income approach in its pure form does not allow for establishment of a present and therefore workable figure of value, since the valuator is looking at estimated future income streams in their expression at the future time at which they are estimated to accrue. ${ }^{414}$ This problem is solved

413 Note that these are computed using the respective brand-specific cash inflows and cash outflows. Due to the fact that the brand proprietor may be in a stronger bargaining position both on the buy and the sell side than without the brand, brand-related savings with respect to e.g. raw material that the proprietor needs to buy must be included in the equation.

414 The major benefit the income approach brings about vis-à-vis cost and market approaches is its future orientation brought about by the employment of future income streams. For example, a toy manufacturer is estimated to earn $€ 100,000$ in the upcoming fiscal year and $€ 150,000$ in the year thereafter due to a certain brand. However, these figures express the worth of the respective income at the respective future date. As will be seen below, future money does not have the same value as present money. In order to be able to value the brand today, one therefore needs to turn these future figures into a figure representing those values today, at the time of valuation. 
by a variation of the income approach, the so-called discounted cash flow or DCF method. ${ }^{415}$ It allows the valuator to discount, i.e. use a certain interest rate on, the future revenue streams associated with the relevant IP to a net present value (NPV) and thereby to arrive at a present value figure he can work with. In other words, the appraiser is able to express all relevant estimated future revenue streams in a value parameter related to the time of valuation. Since income approach and DCF method have to be necessarily intertwined in order to arrive at a present value figure, the DCF method will be briefly introduced in the following paragraphs. ${ }^{416}$

The DCF method is based on the fundamental rule that money loses value over time, or - in other words - present money is more valuable than future money. This is due to two influencing factors: inflation and risk, i.e. uncertainty regarding future developments. ${ }^{417}$ This type of uncertainty, for example regarding a possible shortage in crude oil, makes investments, i.e. the transformation of monetary (liquid) capital into real (fixed) capital, risky. Invested money may be increased, kept at the original level or even lost. As a general rule, this risk, together with inflation, makes investors prefer liquidity over investments. ${ }^{418}$ In consequence, once they have in fact invested, investors will always demand a rate of return on that investment reflecting the degree of risk involved. In a DCF calculation, it is the interest rate which reflects such risk.

In general terms, the value of an income stream $\mathrm{x}$ received in $\mathrm{t}$ years from the time of valuation will be worth $\mathrm{v}(\mathrm{x})$ at the valuation time, or

$$
v(x)=\frac{x}{(1+d)^{t}}
$$

415 In fact, the income approach in its basic form and the DCF method are oftentimes not distinguished at all but discussed as one unit under the denotation 'income approach'. This is dogmatically wrong but reflects the fact that the income approach is nearly always used and only makes sense for valuation purposes in that form, i.e. discounting the estimated future income streams to be represented as a current value.

416 Should the reader wish to learn more about the DCF method, he will find detailed information in sources such as Audörsch, Moderne Bewertungsverfahren für Aktien, chapter 4.2; Geddes, An Introduction to Corporate Finance. Transactions and Techniques, pp. 189 et seq.; King, Valuation: what assets are really worth, pp. 92-98 and Razgaitis, Valuation and Pricing of Technology-Based Intellectual Property, pp. 179 et seq.

417 Groppelli/Nikbakht, Finance, p. 51.

418 So-called 'liquidity preference', cf. Brealey/Myers, Principles of Corporate Finance, p. 680 . 
with d being the discount rate (also called interest rate) and e.g. 0.1 expressing a $10 \%$ rate. This equation can be used to calculate the NPV of income streams received in one period. Usually, the appraiser aims at discounting estimated future cash flows accrued during a number of years or periods, e.g. the remaining useful life of a brand. ${ }^{419}$

This shows that a DCF calculation presupposes a number of parameters: the size of the estimated future income stream in each period (usually per year), the number of periods (which is, in maximum, the total remaining useful life of the asset) and the interest rate.

As with respect to the income approach in its pure form, the key issue of the DCF method is the prognosis of income streams. The main problem in this context is how to separate the expected cash flow derived exclusively from the asset under valuation, e.g. a brand, from all other cash flows. Since income approach and DCF method work inextricably together and can be treated as one unit, problem and solution approaches are the same. One suggested way of solving this issue is application of the price premium method, a technique derived from the income approach, which will be discussed below at $3.2 \cdot 2.2 .1 .^{420}$

The DCF method is commonly applied with respect to a five-year forecast period (data regarding which can usually be retrieved from the business $\operatorname{plan}^{421}$ ) and, if possible and necessary, a prognosed annuity related to the remaining estimated lifespan of the brand in question. ${ }^{422}$ These two time phases constitute the remaining useful life of the respective brand. ${ }^{423}$

419 In order to achieve this, supposing the remaining useful life of the respective brand is four years, the equation will have to look like this:

$$
v(x)=\frac{x}{(1+d)^{1}}+\frac{x}{(1+d)^{2}}+\frac{x}{(1+d)^{3}}+\frac{x}{(1+d)^{4}}
$$

420 Others include mass premia, hedonic prices or the licence analogy method, cf. Sattler, Markenbewertung: State of the Art, pp. 12-18 and Völckner/Pirchegger, Immaterielle Werte in der internen und externen Berichterstattung deutscher Unternehmen - Eine empirische Bestandsaufnahme, p. 11. Licence analogy which will be introduced below at 3.2.2.2.2.

421 Ehrler, Ein DCF-Modell zur Markenbewertung, p. 76.

422 Interbrand Zintzmeyer \& Lux, Brand Valuation. The key to unlock the Benefits from your Brand Assets, p. 2.

423 This is, as a general rule, the shorter of the economic life (i.e. the period in which the asset is expected to yield economic return) or the legal life (i.e. the period during which the asset is legally protected), cf. International Valuation Standards Committee, International Valuation Standards, pp. 191/192. Other than in the case of patents, for 
Even though one may infer from a preliminary look at the theoretically infinite legal life of trade marks that brands have an infinitive useful life, ${ }^{424}$ this cannot be said to be a valid statement as a general rule. As brands live in the minds of the target audience who would forget about brands if there were no repeated contacts with them over time, brands need to be kept alive by application of marketing instruments such as introduction of new product lines and advertising. ${ }^{425}$ In most cases, therefore, market and product life cycle analyses show a limited remaining useful life of the brand in question. ${ }^{426}$ The time span during which the respective brand is intended to be used is also crucial for the assessment of its remaining useful life. This can differ considerably depending on the type of brand involved. A single or product brand

which the remaining useful life is easy to obtain due to their temporally limited legal life (patent protection lasts, as a basic rule, for 20 years from the filing date, cf. $§ 16(1)$ first sentence PatG; Art. 63(1) EPC. A so-called supplementary protection certificate (SPC) extends the duration of a pharmaceutical patent for a maximum of five years since products related to such patents need to undergo official approval before they are allowed to be marketed. The SPC is aimed at providing a time compensation since such approval procedures can take several years, the patent protection term already runs during such approval phase and most pharmaceutical patents only yield a positive return on investment (if at all) in the extended duration granted by the SPC. SPCs are governed by e.g. § 16a PatG and the Council Regulation (EEC) No. 1768/92 of 18 June 1992 concerning the creation of a supplementary protection certificate for medicinal products (Official Journal L 182 of July 2, 1992).), the situation is very difficult with respect to brands, since the underlying trade marks can be theoretically renewed ad infinitum (textsection 47(2) MarkenG; Art. 46 CTMR). The oldest trade marks in the German register, for instance, are more than 110 years old (one of the oldest German trade marks registered for Nice classes 1 and 5 is the word mark SALOL listed under number 5967, bearing the filing date of October 1st, 1894, the registration date of May 2nd, 1895 and belonging to Bristol-Myers Squibb GmbH in Munich). Since the legal life of trade marks is theoretically infinite, the abovementioned general rule does not apply (save in cases where it is certain that the respective trade mark will not be renewed), which bears the consequence that the economic life must be resorted to. This is much harder to assess than a limited legal life, where available, since estimating the time span during which an asset is expected to give return generally brings about considerably more uncertainty than assessing its legal (statutory) protection term. The circumstance that a brand can live on without the trade mark being legally protected (see chapter two at 2.1.2.) also shows that the legal life of a trade mark contains little information on the remaining useful life of the respective brand. It almost completely disconnects the search for a reasonable useful life figure from legal questions regarding duration of protection (except for those cases in which the trade mark proprietor clearly intends not to renew the mark (with respect to registered trade marks) or not to use the mark in the future respectively (in case of well-known marks)).

424 Brands are in fact frequently claimed to have indefinite useful economic lives, cf. Brand Finance, Implications of the new international accounting standards for intellectual property owners, p. 2.

425 Cf. Greinert, BB 2004, 483.

426 Institut der Wirtschaftsprüfer (IDW), Entwurf IDW Standard: Grundsätze zur Bewertung immaterieller Vermögenswerte (IDW ES 5), p. 17. 
the respective products of which shall only be used for a limited time span and which shall not be transferred to similar products has a relatively limited useful life compared to an umbrella or company brand the use of which does not depend on the life cycle of a specific product or service line. ${ }^{427}$

It follows that the economic life of a brand needs to be determined on a caseby-case basis. Important factors influencing such analysis include product life cycles, the time span in which management intends to use the brand, to keep it alive through producing branded goods/rendering branded services and to maintain it using marketing means which sustain the brand in the minds of the target audience.

As mentioned above, the discount rate reflects the risk associated with the respective estimated cash flow. It is composed of a risk-free rate and a specific risk rate. The risk-free interest rate can be obtained by investment in financial instruments with no default risk. ${ }^{428}$ Since truly risk-free interest rates are a theoretical construct, practitioners use short-dated bonds of the respective currency. ${ }^{429}$ The risk rate is a crucial factor in any DCF calculation. A modification of as little as .5\% may cause considerable differences in value outcome, since income streams are estimated and discounted over a number of years. However, in the course of a rather 'mechanical' and unilaterally financial tool like the DCF method, the valuator does not have the chance to collect all salient data for a comprehensive risk assessment which would lead him to an appropriate discount rate.

In order to make the discounted cash flow projections more robust, especially in a setting like valuation of intellectual property which involves a relatively high degree of risk, the so-called decision tree analysis can be deployed. Specific risks associated with certain alternative future cash flow scenarios are identified and dealt with using a probability weighting. ${ }^{430}$ All available alternatives are then visualised by means of a decision tree, within which estimated future events and activities are illustrated using forks (which look like branches of a tree). The best alternative can then be computed. ${ }^{431}$

427 Greinert, BB 2004, 483, 486.

428 However, the financial instrument may carry other risks, e.g. market and liquidity risk.

429 For Euro investments, German government bills or EURIBOR (Euro Interbank Offered Rate, a daily reference rate based on the averaged interest rates at which banks offer to lend unsecured funds to other banks in the Euro wholesale money market) rates are commonly used since the risk of a Government or the European bank system defaulting is estimated to be extremely low.

430 Woodward, Valuation of intellectual property, p. 3. 
Since a decision tree analysis can only be as good as the underlying data, it is not a method for finding out new alternatives but rather a solid means of untangling complex future scenarios by visualising the likelihood of the respective foreseen alternatives. In the context of a DCF analysis, a decision tree enables the appraiser to calculate a probability-adjusted cash flow, which reflects inherent risks considerably better than a mere calculation of one alternative cash flow scenario. It should therefore be part of every income approach and DCF analysis.

The income approach in its pure form, that is without DCF and decision tree analysis, impresses with its future orientation. It thus contributes to attaining a manageable valuation outcome and thereby meets one fundamental requirement of all strategic valuations. However, it is not until discounted cash flow calculations and decision tree analysis come into play that this approach demonstrates general capability of being reasonably utilised for strategic intellectual property valuation. Discounted cash flow analysis allows estimated future income streams to be expressed in monetary terms valid at the time of valuation. Decision tree analysis enables the appraiser to calculate not just one but all estimated future scenarios. This, due to combination of factual and monetary forecasts, can be utilised in the course of strategic decision making. What is more, such approach is not just transparent and relatively easy to handle but also widely applied.

However, this cannot belie the fact that its output is not fully conceptually and methodically sound with respect to purposes of strategic evaluations. It covers merely one side of value, the financial one. Estimation of future income streams and risk rate determination do not reflect non-financial, qualitative value influencing factors such as legal strength of the trade mark or brand

431 The following decision tree is a simplified example visualising the 80:20 chance that the market will develop well in a certain country (first fork) and a 60:40 chance that a certain branded product will sell as expected (second fork).

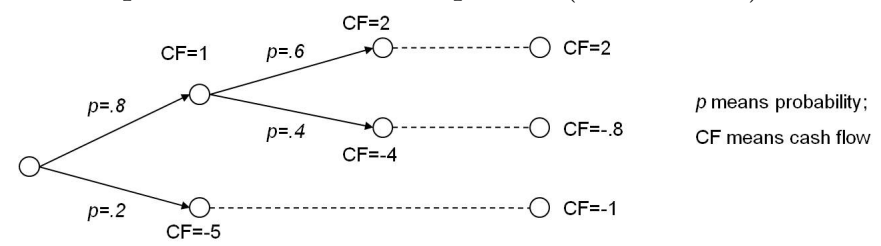

In the most likely event, forecast cash flow will be .8 times 1 plus .6 times 2 , which equals 2 . In the least likely event (negative market development), forecast cash flow will be .2 times -5 , or -1 . The value of the respective brand would be estimated (again, in a considerably simplified way) at .2 (adding up the results of all possibilities). 
strength.

It follows that the income approach, coupled with discounted cash flow calculations and decision tree analysis, is a solid means of dealing with futurerelated IP valuations, at least from a purely financial point of view. It resembles the concept of value more closely than the cost approach and - with respect to intellectual assets - also more closely than the market approach.

The fact that the income approach has a long history of being utilised in valuation of assets other than intellectual property is, on the one side, advantageous since it gives valuators the opportunity to fall back on a known procedure for assessment of a relatively new asset class. On the other hand, this seems to bar the fact that intellectual property (e)valuation can only succeed with a contextual modus operandi, including examination of value determinants other than financial ones, from winning adequate recognition.

\subsubsection{Derivative Generic and Proprietary Methods}

All financial generic and proprietary brand valuation models are based on and contain some reference to one or several of the general valuation approaches just introduced. ${ }^{432}$

With respect to financial brand valuation, the abovementioned surveys indicate practitioners' fondness for both the market and particularly the income approach in their conventional form. ${ }^{433}$ Some generic variations of the income approach are relatively popular whereas proprietary methods seem to attain very little market share.

Since the three general approaches have been illuminated above, two generic variations (the price premium and licence analogy/relief from royalty methods) and one proprietary tool (WoReWert@ by Repenn) have been selected for scrutiny, based on - as a general rule - distribution rates according to the abovementioned surveys. ${ }^{434}$ The price premium approach attained the

432 They can therefore be theoretically sub-categorised into three groups (cost-, incomeand market oriented methods). However, this is not further pursued in this study since the increased degree of comparability obtained would be outweighed by excess complexity.

433 As seen above, the income approach per se has gained the highest distribution rate of all financial brand valuation methods. Determination of brand related profit was deployed by $40.3 \%$ and examination of brand related revenue by $23.9 \%$ of all queried experts, cf. 3.1.3.5. 
highest distribution rate of all variant forms of either of the three general approaches, that is a distribution rate of $17.9 \%$ (Günther et al.) and $29.6 \%$ respectively ( Völckner et al.). The licence analogy/relief from royalty method came second, reaching a market share of $11.1 \%$ (Völckner et al.). None of the proprietary financial techniques have achieved notable popularity in the course of the abovementioned surveys. Hence, the valuation tool by Repenn has been selected on the basis of data availability only. ${ }^{435}$

Like the three general approaches, the two generic methods which will now be discussed are used for all kinds of IP assets. By contrast, the proprietary tool has been specifically developed for trade marks. ${ }^{436}$

\subsection{Price Premium}

Brand valuation under application of the price premium method defines brand value as the excess amount which consumers are willing to pay for a branded product or service versus an unbranded one. In other words, this technique is based on the assumptions that a brand allows its proprietor to demand a price premium compared to unbranded products and that this premium alone reflects the brand's value. This assumption rests upon consumers' brand perception mechanisms since preference building and customer retention are the basis for assertion of a price premium, bearing in mind that

434 Other generic financial brand valuation techniques (of which some are mostly being used for accounting purposes) include the cost savings method, the excess operating profits (see Woodward, Valuation of intellectual property) or multi-period excess earnings method (Residualwertmethode) (cf. Hanser/Högl/Maul (ed.), Markenbewertung. Die Tank AG, p. 52), the incremental cash flow method (Mehrgewinnmethode) and the real options pricing method. Further proprietary financial brand valuation methods include the pricing model by Blackston, licence based brand valuation or VALMATRIX@ by Consor, Crimmins' pricing model, the TESI pricing model by Erichson, the momentum-accounting approach by Farquhar/Ijiri, the Customer Value Method (RoCS Model) by Fischer et al., the market value model by Herp, the cash-flow method by Kapferer, the brand value formula by Kern, Sander's hedonic pricing model, the stock value model by Simon/Sullivan and others. Cf. fn. 386 for references. Note that the book 'Markenbewertung. Die Tank AG' contains a chapter called 'KPMG-Model'. This caption can be misunderstood since no proprietary method is introduced yet a few generic variations of the income approach are applied.

435 The WoReWert@ tool is - amongst others - documented in Bentele/Buchele/Hoepfner/Liebert, Markenwert und Markenwertermittlung, pp. 53 et seq., Repenn/Weidenhiller, Markenbewertung und Markenverwertung and Zimmermann/Klein-Bölting/Sander/Murad-Aga, Brand Equity Excellence, Vol. 1: Brand Equity Review, pp. 34-35.

436 Repenn/Weidenhiller, Markenbewertung und Markenverwertung, p. 90. 
brand-oriented consumers generally show lower price elasticity of demand ${ }^{437}$ compared to consumers paying little or no attention to brands. ${ }^{438}$

However, customer-related non-financial factors do not play a role in the actual computation of brand value in the framework of the price premium method. In essence, this method has emerged as an attempt to solve the problem of separating brand-specific earnings from all other earnings for purposes of income approach-based calculations.

A price premium is computed by subtracting sales earnings accrued from a comparable unbranded product or service from earnings accrued from the respective branded product or service. Earnings from the unbranded item are seen as representing the value of the item only, since no additional branding is said to be involved. Hence, by subtracting these figures from sales earnings accrued with respect to the branded item the appraiser arrives at a figure representing the value of the brand only.

As a relatively straightforward tool (at least in theory), the price premium method is intuitively appealing. Required sales price data is publicly available. ${ }^{439}$ This makes the price premium method easier to use and more transparent than others. Furthermore, it is replicable, future oriented and provides the valuator with a monetary outcome.

However, having to find a comparable unbranded product or service for every brand to be valued often proves difficult. ${ }^{440}$ At this point, the theoretically attractive price premium method shows its main and substantial defect. In fact, the search for unbranded items is a fiction. There may be products or services of comparable quality on the market yet even if they were branded with a 'no name' brand, they still would be branded. Nevertheless, some regard such items as unbranded. However, this ignores the fact that cheap or 'no name' brands are in fact complete brands with some value. There are no completely unbranded goods or services on the market. ${ }^{441}$ Especially the so-called 'store brands', the respective products of which some treat as

437 The term price elasticity of demand stands for buyers' responsiveness or sensitivity to changes in price (cf. Silbiger, The 10-day MBA, p. 294). See above at 2.1.2.2.3.

438 Hence, price premia are proxies for the elasticity of demand, cf. Simon/Sullivan, 12 Marketing Science, iss. 1, 28, 29 (winter 1993). Q.v. Aaker, Management des Markenwerts, p. 19.

439 Competitors will in general be able to compute sales earnings from such data. Contrary to this, sales volume data is not always freely available.

440 Esch/Geus, Ansätze zur Messung des Markenwerts, p. 1283.

441 Stucky, Interbrand-Modell, p. 106. 
unbranded, have gone through a considerable image change in recent years. Even though products marked with such brands are positioned in the lowprice segment, consumers increasingly perceive brands such as CIEN or JA! $!^{442}$ as representing a worthwhile value for money quality. Hence, at least some of such brands have left the realm of brands with very little value and represent their very own 'value for money brands' segment.

In addition, price premia, in most cases, result from high-quality physical attributes of the respective product, as well as from brand-related factors, and not solely from the brand itself. ${ }^{443}$ Not only does this make the detection of a comparable unbranded product intricate, it also shows that a price premium method will in general arrive at too high estimates of brand value unless there is adjustment for the difference in production cost. ${ }^{444}$

What is more, the assumption that the price premium alone reflects the respective brand's value cannot be confirmed. First of all, a brand audience does not merely consist of consumers. In fact, a brand's value is also influenced by its impact on suppliers, staff and the financial community. For example, strong brands can be leveraged to lower cost of supplies and thus to raise profitability. ${ }^{445}$ Secondly, even though the income reflected by the price premium is an important part of brand value, there are other value components which are, as such, not financial (and therefore need to be transformed into a monetary figure in the course of valuation in order to arrive at a monetary outcome), such as brand strength. The price premium technique is therefore not capable of comprehensively dealing with quantitative and qualitative contextual value drivers and distractors. ${ }^{446}$

It follows that the price premium method is not suitable for comprehensive strategic brand valuation, at least not by itself. As a generic variation of the income approach, it features shortcomings inherent in that approach such as the one-sided focus on financial figures. In addition, it holds conceptual drawbacks related to the fact that earnings accrued with respect to a (fictitious) comparable unbranded good or service need to be computed.

442 CIEn is a store brand used by Aldi and JA! is utilised by REWE. Cf. also fn. 129 and 2.1.2.2.2.

443 Stucky, Interbrand-Modell, p. 106.

444 Simon/Sullivan, 12 Marketing Science, iss. 1, 28, 30 (winter 1993).

445 Haigh, Brand valuation: what it means and why it matters, p. 21.

446 Bearing in mind that the price premium method, in essence, is an attempt to solve the issue of separation of brand-related income streams from all other income streams, this result is not very surprising. 


\subsection{Licence Analogy / Relief from Royalty}

A relatively widely used approach for operationalising brand-related value streams is the licence analogy method, another generic variation of the income approach. It is based on royalty rates, customary within the respective industry, for brands comparable to the one to be valued. Hence, the value of the brand in question is inferred from royalty rates used for reference brands.

Once such a comparable royalty rate is found, brand value can be computed as the sum of annual royalty payments over the duration (in years) of the licence, less cost for creation and maintenance of the brand over the same duration. ${ }^{447}$ This sum will have to be discounted in order to arrive at a net present value. ${ }^{48}$ Such value shows what the future royalty payments less cost reflecting the value of the brand are worth at the time of valuation.

The so-called 'relief from royalty' technique is similar to a licensing analogy but with a theoretically different angle. It uses the fiction that the proprietor, were he not owner of the respective brand and as such relieved from paying royalties for it, would have to licence it in. The relief from royalty method operationalises brand value by projecting a fictitious value stream represented by a royalty rate, thereby determining the cost avoided through ownership of the brand. This rate is usually based on a percentage of marketplace sales or turnover. ${ }^{449}$ Hence, the valuation process consists of first estimating the royalty fee as a percentage of sales or turnover and then projecting that fee over the remaining useful life of the brand. As a next step, one needs to compute the net present value (as above).

Either of these modi operandi, licence analogy and relief from royalty, are comprehensible and (due to their generic nature) transparent in concept and method. Like the price premium technique, they result in a monetary value figure. However, they entail a considerable number of problematic issues.

Firstly, finding one or several brands of close enough comparability will in most cases be extremely difficult. This may still be relatively well feasible with respect to fast moving consumer goods brands because there are many similar products originating from different producers or brand proprietors in this market. Yet with respect to most markets, the hurdle of regarding

447 Cf. Fabry, 3 Journal of Business Chemistry, iss. 3, 27, 29 (2006).

448 See above at 3.2.2.1.3 as to how this is done.

449 Sattler, Markenbewertung: State of the Art, p. 17. 
one brand comparable to another one needs to be lowered so considerably in order to find a suitable brand that the reference brand thus found will have more differences than similarities vis-à-vis the brand under valuation. The difficulty here is, in essence, the same as with respect to the market approach, since comparable transactions or brands respectively need to be found.

Secondly, it is far from guaranteed that, if a comparable brand was found, its royalty rates have been made public. However, the licence analogy method can solely be used appropriately in cases of available licensing information from assets comparable to the one in question. Ideally, one would at least look for brands with a similar market share in the same industry and market segment which generate income streams similar to the brand to be valued. However, such detailed information is generally unavailable due to confidentiality reasons. ${ }^{450}$ One therefore needs to rely on the few publicly available royalty rate sources which usually merely mention rates common in certain industries without providing names and other details of specific reference brands. ${ }^{451}$ Hence, such royalty rates will in most cases be speculative and could at best be applied as a rule of thumb.

In addition, using licence royalty rates from other brands, i.e. transferring them to other than the original transaction they were used for, implies that such rates are objectively calculated or can at least be objectified. However, this neglects the fact that there can be a number of subjective tactical and strategic motivations on either side leading to the respective royalty rate. ${ }^{452}$ For example, a licensor may want to give a certain licensee a discount on the royalty rate he would usually demand because he may wish to tie the licensee down to himself for purposes of future strategic alliances. Specific

450 There are, however, a few commercial databases containing information on current or past licensing agreements such as turnover and licensing term. An example is the brand consultancy blueDOM who maintain such a database for use in client assignments, cf. http://www.bluedom.ch/nav \_c/nav \_c.html \\# (last accessed November 29, 2006). The US consultancy Consor seems to be using an archive with more than 8,500 entries of past licence and sale transactions for their commercial brand valuation tool, cf. Zimmermann/Klein-Bölting/Sander/Murad-Aga, Brand Equity Excellence, Volume 1: Brand Equity Review, p. 36. Both seem to keep the respective data secret and would find their clients a royalty rate without divulging the underlying information.

451 Such sources are available for some IP assets, especially brands and copyrights, cf. Anson/Suchy, Fundamentals of Intellectual Property Valuation: A Primer for Identifying and Determining Value, p. 35. There are articles published in regular intervals like the German ones written by Groß, e.g. in WRP 2003, 1199.

452 Cf. Zimmermann/Klein-Bölting/Sander/Murad-Aga, Brand Equity Excellence, Volume 1: Brand Equity Review, p. 37 and above at 3.2.2.1.2. 
warranties or indemnities in the licensing agreement or tax considerations may also have a unique implication on size and type of the royalty rate. Using this royalty rate in a situation with a different brand and proprietor is of necessity inadequate.

What is more, a financial figure from a licensing situation, which logically presupposes valuation, is being used as basis for a value finding process. Yet such procedure ignores that licensing is in fact one of a number of reasons for valuation. ${ }^{453}$ This means that the licensing object needs to be valued in order to find a royalty rate and not vice versa. Instead of deducing brand value from a royalty rate, one should rather compute and negotiate the royalty rate on the basis of the respective brand's value.

The relief from royalty method involves difficulties in case a competitor's brands are under valuation since up-to-date sales and/or turnover figures are not always publicly available.

Not least, the licence analogy or relief from royalty methods, since they are purely financial tools based on the income approach, entail problems this approach brings about. They too lack a comprehensive and contextual way of processing all the non-financial factors which have a bearing on brand value.

It follows that the licence analogy or relief from royalty techniques present considerable flaws. They can at best provide a very rough indication of the financial dimension in which brand value may be located.

\subsection{WoReWert@ by Repenn}

For the reason that a brand does not constitute an independent property right, Repenn's valuation system ${ }^{454}$ is concerned with trade mark instead of brand value. ${ }^{455}$

It is based on the proposition that a valuation system must be applicable to all kinds of trade marks and many of their uses. ${ }^{456}$ This is a promising

453 Cf. 2.3.2.2.

454 It is sometimes called 'System Repenn', yet 'System Repenn' and 'WoReWert' denote the same technique, cf. Bentele/Buchele/Hoepfner/Liebert, Markenwert und Markenwertermittlung, pp. $53 / 54$.

455 Repenn/Weidenhiller, Markenbewertung und Markenverwertung, p. 3.

456 Kalmbacher/Repenn, Monetäre Bewertung von Marken. Anlässe und Methoden, pp. 13-14. 
rationale, arousing the expectation of its use as basis of a truly comprehensive valuation method.

According to the WoReWert@ method, trade mark value is computed by adding the 'basic value' (Grundwert), which consists of cost of creating and maintaining the trade mark, and the 'operational value' (Betriebswert), which arises from the ongoing use of the respective trade mark. The latter consists of $5 \%$ to $15 \%$ of the average annual turnover accrued within the five years preceding the date of valuation and, where applicable, licensing revenues. ${ }^{457}$ In the case of constant turnover figures, a fixed $10 \%$ shall be used.

It needs to be positively mentioned that WoReWert $\AA$ ) leads to monetary valuation results and is relatively easy to comprehend and apply. ${ }^{458}$

However, it seems to be very past and present but not very much futureoriented. ${ }^{459}$ It operates to a considerable extent with historic data.

What is more, WoReWert $(\mathrm{R}$ is a relatively one-sided and incomplete tool. It measures trade mark value under provision for the cost accrued for generating and maintaining the mark ('basic value') and its utilisation-related performance ('operational value'), thereby combining cost-based and incomebased elements (only). ${ }^{460}$ More importantly, as it is merely concerned with trade marks instead of brands, it is only able to cover a fraction of all the factors and characteristics constituting a brand. Consequentially, determinants which massively influence the value of a brand, such as determination of the relevant product or service market, market leadership and competition as well as the consumer perception side, are ignored.

All in all, the WoReWertR methodology does not seem to be freed from the one-sided constraints a purely financial valuation tool brings about. As it merely deals with trade marks, it cannot cover all the other vital factors of brand value. In addition, it involves a rather arbitrary and fixed percentage

457 Cf. Repenn/Weidenhiller, Markenbewertung und Markenverwertung, p. 91 et seq. The operational value derived from past revenues applies in the case of used marks. When valuing unused marks, an annual fixed amount based on empirical values is taken as a basis (depending on expiry of the use period).

458 Bentele/Buchele/Hoepfner/Liebert, Markenwert und Markenwertermittlung, p. 53.

459 Berger, MarkenR 1999, 271, 275.

460 The utilisation of elements from the income approach cannot belie the fact that WoReWert@ is, due to utilisation of cost-based components, considerably past oriented. This is not useful for strategic valuations. 
representing operational value which is not very helpful for appraisers looking for a methodically sound and flexible valuation tool.

In consequence, WoReWert $\AA$, like the two introduced generic methods, does not provide the appraiser with a comprehensive and contextual valuation process. On top of this, it does not seem to be made for brand valuation at all. Hence, WoReWert $\AA$ is not appropriate for strategic future-oriented brand valuation. Appraisers persisting on using this method should never apply it as a sole brand valuation tool.

\subsubsection{Intermediate Findings}

Financial models usually operate with publicly available data only - in most cases, accounting facts and figures. This bears positively on the valuation process since the valuator only needs to spend little time and money on data aggregation. This contributes to a lean, economical and transparent valuation workflow.

Furthermore, the monetary quantification of brand value, as opposed to a non-monetary one expressed by relative output parameters, can facilitate formal comparability of the economic weight of brands vis-à-vis other valued assets held by the company. ${ }^{461}$ This creates a basis for increased attention to brand-related aspects on the management level. ${ }^{462}$

However, the disadvantages inherent in purely financial valuation methods outweigh their advantages. Some of these drawbacks relate to the fact that such methods are based on one or several of the abovementioned general approaches, which entail a number of problems, passing these on to all derivative methods.

First of all, financial valuation tools bring about inflexible and one-sided valuation mechanisms. Important factors of brand value are being completely left out of the valuation process. Such factors relate to both the effect of the respective brand within the target audience and to non-financial characteristics of the brand as seen from the proprietor's point of view, such as the strength of the underlying legal protection or the quality of the brand management team. The fact that financial methods are quick and transparent

461 Supposing that other assets are valued at the same time under utilisation of the same valuation method.

462 Gerpott/Thomas, WiSt 2004, 394, 398. 
causes them to be tempting. However, their valuation output is, in general, unemployable for strategic valuations, since it is the result of a mechanical and one-sided process.

Financial valuation models are purely quantitative. Consequentially, they merely project part - albeit an important part - of the value of the asset under scrutiny. Even though this means that a diligent valuator will not exclusively rely on such methods, he may still use them as a starting point or in order to obtain a rough picture or a first lead of where the value may reside. This applies especially to income-based methods due to their future-oriented nature. By contrast, historic cost-based tools are by definition unsuitable for any future-oriented valuations. Market-based techniques fail with respect to intellectual property assets due to the lack of usable data.

One core issue of the income approach is separation of brand-related income streams. A number of derivative methods have emerged in order to solve this problem. However, each of them is based on at least one defect, for example the assumption that price premia are derived exclusively from the respective brand. This causes skewed valuation output.

Proprietary financial brand valuation methods are (like generic ones) by definition not able to free themselves from the flaws and constraints involved in financial tools. They do not seem to bring about much noteworthy added value vis-à-vis generic financial techniques. Their market shares are therefore very low.

\subsubsection{Psychographic Models}

From a behavioural science point of view, brand value does not lie within the respective proprietor company but develops within the mind of the consumer. ${ }^{463}$ It is mirrored in brand-connected knowledge structures within the target audience. ${ }^{464}$ As brand value therefore cannot be measured directly, its operationalisation and measurement is carried out by means of consumerrelated, non-monetary brand value indicators (both per se and accompanied by other operators).

463 Esch/Geus, Ansätze zur Messung des Markenwerts, p. 1266.

464 Frahm, Markenbewertung. Ein empirischer Vergleich von Bewertungsmethoden und Markenwertindikatoren, p. 19. Cf. above at 2.1.2.2.1. 
Psychographic brand valuation models contrast strongly with financial ones since they do not arrive at a monetary value outcome. Rather, they operate with qualitative data as sole input parameters and arrive at a non-financial relative brand value or psychological brand strength figure as valuation results.

Such brand valuation methods are based on data collected about cognitions or behaviour patterns of current or potential consumers of branded marketing output. ${ }^{465}$ Market research institutes play a key role in aggregation of such data. They conduct both secondary research, which is based on already existing data such as official statistics, and - in case the secondary research does not meet all information needs - primary research, which is carried out by means of both customer interviews and consumer observations. ${ }^{466}$

The two psychographic valuation methods chosen for assessment in this work are the 'Brand Iceberg' model by Icon Added Value ${ }^{467}$ (proprietary) and the examination of one single or a combination of several brand value indicators (non-proprietary). ${ }^{468}$ Examination of single brand value indicators has achieved a diffusion rate of $77.8 \%$ and combination of brand value indicators has attained market share of $44.4 \%$ (Völckner/Pirchegger). Strictly speaking, these are two separate means of brand valuation, yet since both consist of value indicator examination, they are treated as one for the purposes of this work. The 'Brand Iceberg' model ranks second with a market share of $15.0 \%$

465 Gerpott/Thomas, WiSt 2004, 394, 398.

466 Böhler/Scigliano, Marketing-Management, pp. 30-31. Client interviews are based on standardised surveys and queries which are to deliver information on consumer descriptions of brand attributes (such as the correct allocation of a symbol or device to the respective brand), brand-related preferences, memories or attitudes such as brand loyalty, cf. Gerpott/Thomas, WiSt 2004, 394, 398.

467 http://www.icon-added-value.com (last accessed November 5, 2006).

468 Further customer-related or psychographic valuation tools, all of which are proprietary, include 'Brand Equity Ten' by Aaker, the 'Brand Image Clarity- and Attractiveness Index' ('Markenbildklarheits- und Attraktivitäts- Index') by Andresen, the 'Genetic Code' ('Genetischer Code der Marke') by Institut für Markentechnik (Institute for Brand Technology), Young 8 Rubicam's 'Brand Asset Valuator', 'Brand Championship' by Roland Berger, 'Brand Dynamics' by Millward Brown, 'Brand Potential Analysis' from $B B D O$, 'Brand Stewardship' by Ogilvy $\&$ Mather, 'Equi Trend' by Total Research, IPSOS-ASI's 'Equity Builder', 'Equity Engine' from Research International, 'IMP/SYS' by NFO Infratest, Keller's 'Consumer Model' ('Konsumentenmodell'), 'Brand Barometer' ('Markenbarometer') by TNS Emnid/Horizont, 'Brand Monopolies' ('Markenmonopole') by Konzept \& Analyse, 'Brand Character' by Grey, 'Brand Simulator' ('Markensimulator') from Gesellschaft für Konsumforschung (GfK) and others. For references cf. footnote 386. All found psychographic brand valuation methods are proprietary, except for the examination of (one or several) brand value indicators. 
(Drees) or $12.8 \%$ respectively (Schimansky et al.).

\subsubsection{Examination of Indicators}

There is a large number of brand value indicators, which exist for every area, financial and non-financial, in which brands can have an impact. For clarity purposes, such success indicators can be subdivided into indicators relating to historic developments, current market position, current consumer judgment, and trend. ${ }^{469}$ Others ${ }^{470}$ use generic terms such as product, price, distribution and marketing communication policy, industry sector, future orientation and communication between company and society.

The following paragraphs will allude to psychological, consumer-oriented indicators only, such as customer satisfaction, acceptance of the brand, brand sympathy, brand image and brand loyalty. ${ }^{471}$

Such indicators are used in various combinations and processes, with diverging functions and applied on different problem areas, depending on the respective valuation tool. ${ }^{472}$ Even though most valuation techniques use indicators in connection with other processes, indicators are also applied per se.

Relatively little can be learnt about how exactly a psychographic brand value indicator is applied in practice. However, direct comparison of relevant data suggests itself. For example, a company seeking to evaluate consumer loyalty to its brands compared to the biggest competitor brands can commission market research on the basis of which the respective relative brand loyalty figures are then computed.

This shows that the strength of evaluating one or several brand value indicators lies in selective comparative industry studies. Such work is of significant importance for brand management purposes. To its advantage, all required data is publicly available or can be collected in public. Moreover, examination of indicators is a transparent and easy-to-understand valuation method.

469 Cf. Sattler, Wovon hängt der langfristige Wert von Marken ab?, p. 3.

470 Bentele/Buchele/Hoepfner/Liebert, Markenwert und Markenwertermittlung, p. 156 et seq.

471 There is no uniform system of denoting such indicators. In consequence, there may be considerable overlap between different indicators.

472 Frahm, Markenbewertung. Ein empirischer Vergleich von Bewertungsmethoden und Markenwertindikatoren, p. 25. 
It can be flexibly adjusted to the respective valuation needs.

However, the main drawback with respect to valuation as put forward in this work is the fact that there is no comprehensive contextual assessment of all types of value determinants. This method merely gives the appraiser insights into one confined area of value. It is therefore not suitable for holistic strategic valuations as discussed in this work.

Furthermore, a sole look at brand value indicators, like all psychographic valuation tools, does not allow for a monetary valuation result. This is, however, needed for most valuation purposes and therefore enables widespread acceptance of the respective valuation method. ${ }^{473}$

In summary, examination of brand value indicators is a transparent and flexible tool which can be very useful for certain valuation scenarios in the context of brand management and strategy. However, it is not generally suitable for purposes of comprehensive strategic valuations.

\subsubsection{Brand Iceberg Model by Icon Added Value}

The Brand Iceberg model ${ }^{474}$ was developed in the 1990 s by the market research company Icon Added Value, at that time under the name of Icon Forschung und Consulting. ${ }^{475}$

Brand value, according to this method, is expressed by the purely qualitative, psychographic term of brand strength, which reflects brand value from consumers' point of view. Pursuant to the Brand Iceberg model, brand strength is composed of two factors: brand iconography, or image, and brand assets. ${ }^{476}$

Brand iconography comprises all value components which are visible to consumers, such as advertising, product packaging and other actualities resulting from short-term marketing activities. On the other hand, brand assets are

473 See above at 1.4.2.

474 Also known as 'Brand Trek', 'Brand Status' or 'MAX' (Markenbildklarheits- und Attraktivitätsindex). Meanwhile, Icon Added Value have formed a joint venture company with the consultancy Dr. Wieselhuber $\&$ Partner called B.R. Brand Rating, cf. http://www.brand-rating.de/cms/index.php?page=3-komponenten-modell (last accessed December 8, 2006) and B.R. Brand Rating, Monetäre Markenbewertung auf Zielgruppen- und Marktbasis, slide 4. Brand Iceberg is both predecessor and part of the Brand Rating model yet so well-known by itself that it is introduced here. The Brand Rating methodology is, other than Brand Iceberg, a hybrid tool.

475 Cf. Added Value, Die Wurzeln von Icon Added Value: Der Markenerfolg.

476 Spannagl, markenartikel 2001, 38, 42. 
not visible to consumers, or - speaking within the metaphor of an iceberg under water (the brand iconography components are, in consequence, represented by the tip of the iceberg visible above the water line). Brand assets are factors showing the emotional ties of the target group to the respective brand, such as brand sympathy and loyalty. ${ }^{477}$ They represent longer-term changes in consumer attitudes, ${ }^{478}$ which is why brand assets as defined here are in general rather weak with respect to young brands. According to Icon Added Value, brand assets have (like brand image) a direct link to brand success and therefore to brand value, yet can, essentially, only be influenced by brand image. ${ }^{479}$

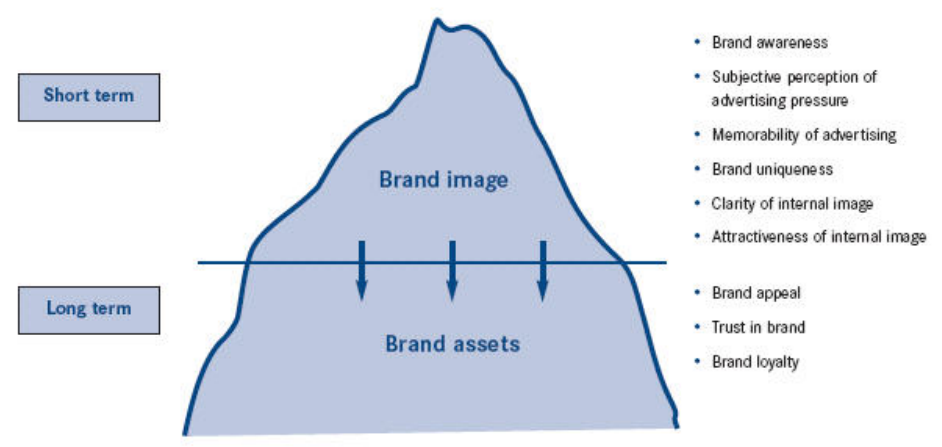

Figure 3.2: Brand Iceberg by Icon Added Value (source: Gebhardt/Stein, Brand Status. Auf Kurs zum Markenerfolg: Marken und ihre Wettbewerber mit den Augen der Zielgruppe sehen, slide 6).

The actual valuation process consists of two phases. First of all, the respective relative brand iconography and brand asset scores are determined. This is carried out by means of customer surveys within the relevant target group. ${ }^{480}$ In a subsequent step, these scores are compared to benchmarks taken from a proprietary database containing corresponding reference values for the market segment in question. ${ }^{481}$ The appraiser thus arrives at a relative non-monetary brand value score.

Like the examination of brand value indicators, the Brand Iceberg model operationalises customer-related factors of brand value, which play a crucial

477 Gebhardt/Stein, Brand Status. Auf Kurs zum Markenerfolg: Marken und ihre Wettbewerber mit den Augen der Zielgruppe sehen, slides 6-9.

478 Zimmermann/Klein-Bölting/Sander/Murad-Aga, Brand Equity Excellence, Volume 1: Brand Equity Review, p. 49.

479 Esch/Geus, Ansätze zur Messung des Markenwerts, p. 1285.

480 Künzel, Die Marke und ihr Wert, p. 113.

481 Bentele/Buchele/Hoepfner/Liebert, Markenwert und Markenwertermittlung, p. 78. 
role in comprehensive brand appraisal. Standardised customer surveys make it as objective as possible. The segmentation of customer-related brand value factors into brand iconography and brand assets facilitates both understanding of the method itself and of coherences on the qualitative side of brand value.

However, it too cannot tide over the fact that merely one important segment of brand value, the qualitative value building or distracting factors in the eye of the consumer, is being illuminated. Financial and other crucial aspects are left aside. The valuation outcome is a point score, which means that the Brand Iceberg is merely suitable for a limited number of valuation scenarios, such as comparative industry studies, for which a purely qualitative, nonmonetary value outcome is sufficient.

In connection herewith, the fact that the brand value score is merely a relative figure stands out negatively as well. Brand Iceberg merely enables the appraiser to find out whether the brand under scrutiny is stronger or weaker (by points) than other brands in the industry. An absolute value cannot be attained. This is, however, a necessary characteristic of a sound brand valuation methodology as defined in this work. ${ }^{482}$

Furthermore, Brand Iceberg does not deliver clarification of the issue to which extent the value outcome is in fact attributable to the brand itself and to which extent it is product or service related. ${ }^{483}$ For example, the fact that the impact which short-term marketing-mix ${ }^{484}$ components such as product packaging have on consumers is measured in the context of brand iconography begs the question how much of a positive consumer feedback would in fact be attributable to quality of the branded product or service and not to the brand itself.

All in all, the Brand Iceberg valuation tool constitutes a viable method for all those valuation purposes in the context of which a relative, benchmarked point score result is sufficient. Qualitative comparative industry studies for example fall in this category. However, the methodology is inadequate for strategic future-oriented brand valuation purposes as introduced in the course of this work. Such type of valuation necessitates a monetary value outcome

482 Cf. above at 1.4.3.2.

483 Cf. Zimmermann/Klein-Bölting/Sander/Murad-Aga, Brand Equity Excellence, Volume 1: Brand Equity Review, p. 50.

484 For a short introduction to the marketing mix, see 2.3.1.1. 
which reflects (amongst others) both financial and qualitative customerrelated aspects. Brand Iceberg is incapable of providing this.

\subsubsection{Intermediate Findings}

The main advantage of psychographic band valuation methods lies in their operationalisation of customer-related brand value parameters. This is an important aspect which financial brand valuation tools are lacking. The degree of brand recognition, loyalty and other such factors have to play an important role in brand value assessment processes, since they are related to measurable marketing and sales success. ${ }^{485}$ Insight into these parameters provided by customer-behavioural methods facilitates management and control of means to strengthen brand value in this regard. ${ }^{486}$

Most customer-related tools are sufficiently transparent, ${ }^{487}$ flexible, futureoriented and bring about adequate degrees of inner logic in order to be sufficiently comprehensible.

However, there are a number of problems associated with these methods which, as a whole, clearly outweigh their advantages. Systematically inherent in solely psychographic valuation models is the central and major drawback that they do not enable the realisation of most types of brand transactions. Monetary output parameters are but an essential precondition for execution of financial transactions such as brand securitisations, acquisitions, divestitures and licensing, to name a few.

What is more, since there is no transformation of psychographic value output into financial parameters, the creation of comparability with other valued assets in a company is made impossible. ${ }^{488}$ Yet such comparability is impor-

485 Spannagl, markenartikel 2001, 38, 39; Esch/Geus, Ansätze zur Messung des Markenwerts, p. 1288.

486 Frahm, Markenbewertung. Ein empirischer Vergleich von Bewertungsmethoden und Markenwertindikatoren, p. 20.

487 However, Brand Iceberg includes a step in the course of which brand iconography and brand asset scores are compared to data sets from a proprietary database, which thwarts transparency.

488 This presupposes that other assets are valued with a monetary outcome, which is usually the case. Supposing this was not so and other assets were valued non-financially, comparability would a fortiori not be existent since assets other than brands cannot be valued with a psychographic method. Psychographic tools are specific to brands since they are the only intellectual property asset / IA the value of which to an essential part is influenced by consumer perception. On the other hand, all IP assets can 
tant for purposes of portfolio management, resource allocation, controlling and general management tasks.

Moreover, the above analysis has shown that there is no general consensus with respect to the selection and weighting of salient input data. ${ }^{489}$ As a consequence, different methods are likely to show considerably diverging valuation results, even if they were applied to the same asset at the same time. This questions composition and systematics of these methods as a whole.

Generally speaking, as much as purely financial brand valuation models unilaterally reflect monetary value components, psychographic methods represent the opposite extreme. They can therefore be used, with appropriate caution, for limited purposes which exclusively involve customer-related, nonfinancial aspects. However, they are unsuitable for comprehensive brand value assessments.

\subsubsection{Financial-Behavioural (Hybrid) Models}

Hybrid brand valuation methods combine modi operandi of financial and psychographic methods, amalgamating their positive and negative aspects to varying degrees.

The following exemplary discussion of hybrid brand valuation tools will address 'Brand Performance System' developed by the marketing research company ACNielsen and the Interbrand valuation model. ${ }^{490}$

The Brand Performance System has, according to Günther et al. and Schi-

be valued with a financial outcome. Hence, if the same methodology was applied to all IP assets within a company, decisions relating to (for example) resource allocation could be taken not just within a portfolio of assets of the same kind, e.g. all patents, but also between e.g. patents and copyrights.

489 Amongst others, Kranz, Markenbewertung - Bestandsaufnahme und kritische Würdigung and Bekmeier-Feuerhahn, Marktorientierte Markenbewertung come to the same conclusion.

490 Other hybrid brand valuation techniques include 'Brand Equity Evaluation System' (BEES) by BBDO, 'MarkenMatik' by McKinsey, BBDO's, Linxweiler's and Meffert/Koers' 'Brand Scorecards', 'Market Oriented Brand Valuation' ('Marktorientierte Markenbewertung') by Bekmeier-Feuerhahn, 'Brand Valuation' from Brand Finance, 'Brand Rating' by B.R. Brand Rating, the methodology by GfK/PricewaterhouseCoopers/Sattler, Kapferer's 'Brand Value Model' ('Markenwertmodell'), the 'Brand Power Model' ('Markenkraftmodell') by GfK, Sattler's indicator model, 'Semion Brand €valuation' by Semion, 'Brand Equity Frame' ('Brand-EquityModellrahmen') by Srivastava/Shocker, the 'Brand Analytics Model' by FutureBrand and others. For references cf. footnote 386 . 
mansky et al., reached a market share of $10.4 \%$ and $3.8 \%$ respectively (which amounts to an average of $7.1 \%) .{ }^{491}$ The method developed by Interbrand attained distribution rates of $3.0 \%$ and $6.1 \%$ respectively (i.e. an average of about $4.5 \%$ ), according to the same studies.

\subsubsection{Brand Performance System by ACNielsen}

The Brand Performance System (also known as Brand Performancer ${ }^{492}$ ) was first introduced in the year 1991 as an advanced version of an earlier brand value measurement system called Brand Balance Sheet (Markenbilanz). ${ }^{493}$ Within Germany, it is marketed in co-operation of ACNielsen and Konzept $\&$ Markt. ${ }^{494}$ It is one of the most widely known proprietary tools for monetary brand valuation in Germany as yet. ${ }^{495}$

Brand Performance System consists of four modules, which can be employed independently or in combination with each other: ${ }^{496}$ Brand Monitor, Brand Value System, Brand Steering System and Brand Control System. The first three of these modules are concerned with brand strength, financial value and brand image as components of overall brand value respectively. Brand Control System is used for brand controlling purposes only ${ }^{497}$ and is not involved in the value finding process. For this reason, it will not be dealt with here.

The central one of these modules, Brand Monitor, allows for assessment of brand strength of all relevant brands within a certain pre-defined market,

491 According to one of the experts involved in the development of this model, it has been applied to more than 400 brands hitherto, cf. Franzen, Das Brand Performance System von ACNielsen: Standardisierte Markenbewertung auf der Grundlage von Marktforschungsdaten, pp. 156 and 165.

492 Cf. e.g. Bentele/Buchele/Hoepfner/Liebert, Markenwert und Markenwertermittlung, pp. 113-116; Gerpott/Thomas, WiSt 2004, 394, 396; Göttgens/Sander/Wirtz/Dunz, Markenbewertung als strategischer Erfolgsfaktor, pp. 11-12; Künzel, die Marke und ihr Wert, p. 164 et seq.

493 Franzen, Das Brand Performance System von ACNielsen: Standardisierte Markenbewertung auf der Grundlage von Marktforschungsdaten, pp. 149 and 153.

494 Konzept \& Markt GmbH is an advisory market research company, cf. http://www.ko nzept-und-markt.com/ (last accessed March 26, 2007).

495 Frahm, Markenbewertung. Ein empirischer Vergleich von Bewertungsmethoden und Markenwertindikatoren, p. 109.

496 Franzen, Das Brand Performance System von ACNielsen: Standardisierte Markenbewertung auf der Grundlage von Marktforschungsdaten, p. 157.

497 Zednik/Strebinger, Marken-Modelle der Praxis. Darstellung, Analyse und kritische Würdigung, p. 112. 


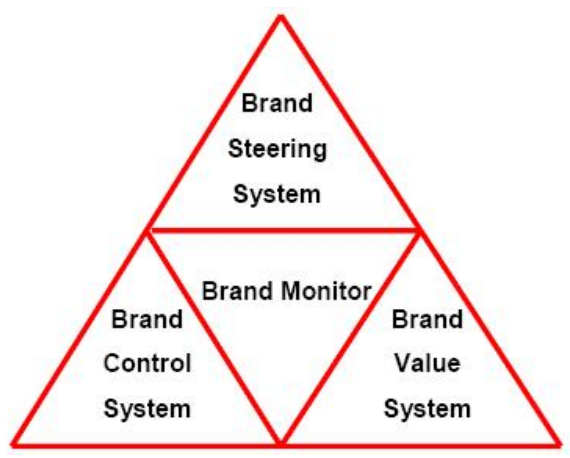

Figure 3.3: The four modules of the ACNielsen Brand Performance System (source: Franzen, Markenbewertung, p. 13.).

based on a point score model. ${ }^{498}$ Ten indicators in four categories are utilised in order to operationalise brand strength. These categories are market attractiveness (represented by market volume and market growth), penetration of the brand within the market (shown on the basis of current status and growth of market share (both in absolute and relative figures)), acceptance of the brand on the demand side (represented by brand awareness and existence of the brand in the so-called relevant set ${ }^{499}$ ) and distribution rate of the brand. ${ }^{500}$ The figures determined for each indicator are then transformed into a point score, whereupon the resulting scores are weighted with pre-defined factors $^{501}$ and as a next step totalled and scaled so that a maximum of 100 points can be attained. ${ }^{502}$ The achieved percentage of this maximum score represents the absolute brand strength.

The fact that data on all four indicators can be obtained with respect to competitor brands means that a relative brand strength, i.e. of one brand

498 Franzen, ACNielsen Brand Performance System, p. 130.

499 A relevant set is the range of brands which would, in principle, be considered by potential consumers in the course of a purchase decision, cf. Künzel, Die Marke und ihr Wert, p. 168.

500 Esch/Geus, Ansätze zur Messung des Markenwerts, p. 1294; Frahm, Markenbewertung. Ein empirischer Vergleich von Bewertungsmethoden und Markenwertindikatoren, p. 111.

501 These factors have been pre-defined according to importance of each of the four indicators. Acceptance on the demand side accounts for 40\%, market penetration for $35 \%$, market attractiveness represents $15 \%$ and the distribution rates make up $10 \%$ (each approximately); cf. Esch/Geus, Ansätze zur Messung des Markenwerts, p. 1294; Franzen, ACNielsen Brand Performance System, pp. 131-132; Künzel, Die Marke und ihr Wert, pp. 167-168.

502 ACNielsen, ACNielsen Brand Performance. Valide Markenbewertung, slide 27; Frahm, Markenbewertung. Ein empirischer Vergleich von Bewertungsmethoden und Markenwertindikatoren, p. 111. 
compared to one or several other brands, can be calculated as well as solely values of competitor brands, in a discrete manner.

Brand Value System, the second module, is based on the income approach and converts the psychographic brand strength obtained with Brand Monitor into a monetary figure. In doing so, brand strength of all brands in the relevant market is initially calculated and the relation between this total brand strength and strength of the brand under valuation is obtained (relative brand strength). Overall profit of the market is then calculated on the basis of operating margin and market volume. ${ }^{503}$ The brand being appraised is then allocated its proportionate profit, based on the relative brand strength obtained before. This profit figure is finally discounted to a net present value by an income-based DCF calculation, whereby infinite useful life of the brand and a constant profit margin are assumed.

Thirdly, Brand Steering System can be applied to determine brand-specific qualitative success factors such as brand sympathy and reputation. This facilitates brand management and its alignment with overall corporate strategy. The development of this third module reflects ACNielsen's primary objectives to both value a brand financially and provide a basis for its strategic management. ${ }^{504}$ It thereby provides a means of brand evaluation compared to mere valuation. ${ }^{505} 506$

Like with all other hybrid brand valuation tools, one major advantage of Brand Performance System is its combination of qualitative psychographic and quantitative financial factors of brand value in one system. It is thereby able to arrive at a monetary value outcome even though non-monetary psy-

503 Zednik/Strebinger, Marken-Modelle der Praxis. Darstellung, Analyse und kritische Würdigung, p. 114.

504 Franzen, ACNielsen Brand Performance System, p. 129.

505 As to the difference between valuation and evaluation cf. 1.1.1.4.

506 In the study "Markenbewertung. Die Tank AG" of 2004 (Hanser/Högl/Maul (ed.): Markenbewertung. Die Tank AG. Düsseldorf 2004), ACNielsen was one of the expert companies which were asked to value a fictitious petroleum brand. It would therefore have been desirable to outline ACNielsen's contribution to the study at this point in order to illuminate Brand Performance System with an example, especially given that the article in "Die Tank AG" seems to be the most detailed one on Brand Performance System publicly available. However, this contribution remains too vague in many important aspects to be a meaningful example of how Brand Performance System is to be applied in practice. It shall be noted, however, that value of the brand "Die Tank AG" as calculated by means of Brand Performance System amounts to $€ 958$ million excluding value added tax - a figure interesting to compare with the one attained by Interbrand (below at 3.2.4.2), which amounts to $€ 463$ million, i.e. barely half of ACNielsen's result. 
chographic factors are operationalised.

Furthermore, it is a procedure which is relatively easy to follow and reproduce since the number of criteria applied is rather small. Since all data necessary to process the indicators used within Brand Monitor is either already publicly available, included in company statistics or can be independently obtained by market research, competitor brands, as well as internal ones, can be valued or evaluated discretely. However, the general statement that this data can be obtained at relatively small effort ${ }^{507}$ cannot be followed as market research, if necessary, can become both relatively costly and time consuming, especially in the case of qualitative market research.

Striking an appropriate balance between transparency and cost-effective applicability on the one hand and a sufficiently detailed valuation process on the other is one of the key methodical issues in the context of brand valuation methods. In the case of Brand Monitor, the fact that merely ten partially similar psychographic indicators in four groups ${ }^{508}$ are used causes serious doubt as to whether enough comprehensiveness and depth is achieved. For example, psychographic success factors are merely expressed through degree of brand awareness and existence of the brand in the relevant set (indicators in the category 'acceptance of the brand on the demand side'). ${ }^{509}$ However, there are a number of other factors playing a role in this regard, such as brand loyalty. This indicator, for instance, operationalises the question whether customers are actually prepared to re-buy the branded product or service. It is therefore an important complement of indicators relating to mere brand awareness.

In addition, qualitative factors or indicators relating to future potential of a brand have been omitted. However, it is recognised that this future potential is a decisive aspect of brand value. ${ }^{510}$ The same applies to possible future risks, for example with respect to competitiveness of the respective brand.

A mere inclusion of estimated future brand-related profit in a DCF calcula-

507 Zednik/Strebinger, Marken-Modelle der Praxis. Darstellung, Analyse und kritische Würdigung, p. 115.

508 In the predecessor method, Brand Balance Sheet, 19 indicators were utilised which caused considerable criticism of interdependencies and overlap amongst the indicators, cf. Künzel, Die Marke und ihr Wert, pp. 165-166; Zimmermann/KleinBölting/Sander/Murad-Aga, Brand Equity Excellence, Volume 1: Brand Equity Review, p. 59. This criticism will have dried out in the light of the small number of indicators used in the new methodology yet it seems that comprehensiveness has been sacrificed for the sake of excess simplicity.

509 Künzel, Die Marke und ihr Wert, p. 172.

510 Sattler/Högl/Hupp, Evaluation of the Financial Value of Brands, p. 11. 
tion does not constitute a sufficient treatment of future-related brand value influencers.

What is more, determination of brand value can, in the course of Brand Value System, only be achieved indirectly through feedback from brand strength of all brands in the relevant market as a whole. This seems to be a rather laborious process.

Furthermore, the brand values attained through the ACNielsen methodology depend to a considerable extent on the definition of size of the relevant market. For example, the brand LAmBorGHini may not be assigned considerable value with respect to the overall car market (since for example market share and existence of the brand in the relevant set are very low), yet the situation is different concerning the luxury car market. Hence, extremely low brand values would be calculated in cases in which the respective market is defined too widely. ${ }^{511}$

On top of this, it needs to be noted that there are certain types of brands, e.g. umbrella and company brands, the value of which cannot be operationalised in view of narrowly-defined markets. ${ }^{512}$ At this point, it becomes apparent that Brand Performance System has been developed mainly for fast moving consumer goods brands and can not be utilised on other types of brands without considerable difficulty. ${ }^{513}$

All in all, Brand Performance System is a relatively comprehensible and transparent ${ }^{514}$ tool, since the data pool employed is well manageable. The fact that relevant competitor brands must be analysed is useful, even though it increases complexity of the valuation process.

However, two main negative aspects need to be recorded. First of all, the goal to create a lean and transparent tool has lead to over-simplification. A number of important value influencing factors such as future potential and psychographic aspects such as brand loyalty are missing. Future orientation has therefore only been achieved in part. Secondly, some assumptions, such

511 Franzen, Das Brand Performance System von ACNielsen: Standardisierte Markenbewertung auf der Grundlage von Marktforschungsdaten, p. 166.

512 See ibid.

513 Künzel, Die Marke und ihr Wert, p. 171. With respect to umbrella and company brands, for example, one would have to define all market sub-segments covered by the respective brand and value them separately. Ultimately, these partial values would have to be added up (ibid., pp. 171-172).

514 Compared to other proprietary methodologies. 
as the constant profit margin and discount factor, are not realistic.

Brand Performance System therefore cannot be recommended to be used extensively and certainly not on all types of brands. It may find limited application for FMCG brands.

\subsubsection{Interbrand Brand Valuation}

Interbrand and the London Business School jointly developed a brand valuation methodology in 1988 which was partially revised in 1993. Today, Interbrand claims their model to be one of the most frequently referenced internationally, to be utilised by (among others) courts in a number of countries and to be the only one which has gained consistent global acceptance during the past decade. ${ }^{515}$

Like ACNielsen's Brand Performance System, this methodology seeks to combine an indicator-based point score with a discounted cash flow analysis. It comprises five steps: segmentation, financial analysis, demand analysis, brand strength analysis and the final calculation of the net present value (NPV) of brand earnings. ${ }^{516}$

The Interbrand valuation model is based on the assumption that consumer behaviour varies from market sub-segment to sub-segment. Therefore, as a first step, the brand under valuation is divided, according to customerrelated, product-related and geographic criteria, into the number of segments (i.e. specific and homogeneous customer groups ${ }^{517}$ ) deemed appropriate. For instance, in the study "Die Tank AG", for which a number of brand valuation specialists were asked to value the fictitious petroleum brand "Tank AG", Interbrand divided the brand into the segments "Oil", "Wash" and "Shop". 518 The valuation in the steps following segmentation is carried out independently for each segment. The final brand value outcome results from addition of the segments' values. ${ }^{519}$

515 Interbrand Zintzmeyer \& Lux, Wert haben und Wert sein. Die Markenbewertung von Interbrand, p. 2; Interbrand Zintzmeyer \& Lux, Brand Valuation. The key to unlock the Benefits from your Brand Assets, p. 4.

516 Interbrand Zintzmeyer \& Lux, Brand Valuation. The key to unlock the Benefits from your Brand Assets, p. 2; Künzel, Die Marke und ihr Wert, p. 130.

517 Stucky, Interbrand-Modell, p. 111.

518 Ibid., p. 109.

519 Stucky, Monetäre Markenbewertung nach dem Interbrand-Ansatz, p. 438. 


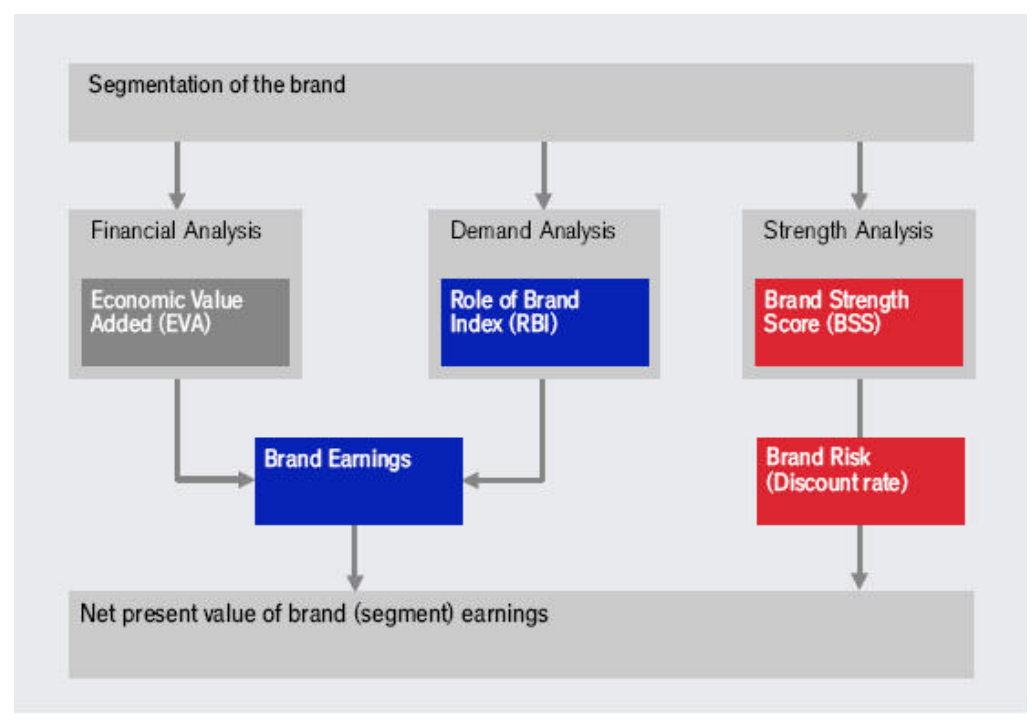

Figure 3.4: An overview of the Interbrand valuation methodology (source: Interbrand Zintzmeyer $\&$ Lux, Brand Valuation. The key to unlock the Benefits from your Brand Assets, p. 2).

Financial analysis is the step following segmentation. Based on a five-year prognosis of future earnings, ${ }^{520}$ a post-tax figure of all such earnings accrued on the basis of all intangible assets in each respective segment is determined $(\mathrm{EVA}){ }^{521}$

Thirdly, the share of this profit attributable to the brand itself is established by identifying the significance of the brand with consumers in each respective segment. This is operationalised by analysis of consumers' demand behaviour and influence of the brand on purchase decisions. ${ }^{522}$ Relevant data, such as brand image, perceived product quality and product range, is collected mainly by means of market research and interviews with company representatives. In this step, the brand's contribution to purchase decisions is singled out from other contributions such as design and exclusivity of a certain product. Thus determined, it is expressed in a percentage figure. This figure is then multiplied by the abovementioned earnings attributable to all

520 A five-year period is used in general because most companies provide such prognosis anyway for purposes of budget allocation, see above at 3.2.2.1.3 and Stucky, Interbrand-Modell, p. 110.

521 Esch/Geus, Ansätze zur Messung des Markenwerts, p. 1291; Stucky, InterbrandModell, p. 110. The figure calculated is the so-called Economic Profit or Economic Value Added (EVA). It remains of earnings before interest and taxes (EBIT) after deduction of tax and cost of capital, cf. Künzel, Die Marke und ihr Wert, p. 131.

522 Zednik/Strebinger, Marken-Modelle der Praxis. Darstellung, Analyse und kritische Würdigung, p. 131. 
intangible assets. The outcome of this calculation is said to constitute brandspecific earnings. ${ }^{523}$ For the study "Die Tank AG", Interbrand estimated, e.g. for the year 2007, an EVA of $€ 55$ million for the brand segment "Oil". Multiplied by a brand significance figure of 33\%, brand-specific earnings for 2007 were calculated to amount to $€ 18$ million. ${ }^{524}$

Subsequently, in order to operationalise the respective brand's earnings risk with respect to each particular segment, brand strength is determined by way of competitor analysis. This is performed utilising seven factors, comparing the brand under valuation to competitor brands and to a fictitious ideal risk-free scenario within the relevant market. ${ }^{525}$ These factors include market dynamics, brand stability and brand protection. The latter deals with legal issues such as type of trade mark registration, registration and defence strategies. ${ }^{526}$ With respect to the brand segment "Oil" of the fictitious brand "Tank AG", for instance, it was found that a relevant trade mark is registered and being monitored; however, there is room for improvement since single elements of the signage (name, picture and/or additional elements) are not separately registered as trade marks and the mark is not registered as a community trade mark (hence, there is no automatic extension to EU accession countries). ${ }^{527}$ The weighted results are incorporated in a point score model, which - utilising a proprietary software - determines brand strength. This brand strength point figure, as representing brand risk, is subsequently transformed into a discount factor by means of a pre-defined s-curve function. ${ }^{528}$

The fifth and last step consists of application of this discount factor in the course of a DCF calculation, showing brand value as an end result. In this respect, the EVA values from step two are multiplied by the brand-specific earnings percentage which resulted from the third valuation step in order to calculate brand earnings for each segment. These are then offset against the discount factor, which results in net present values of these brand earnings forecasted for the respective five-year time horizon. ${ }^{529}$ In order to attain the

523 Stucky, Monetäre Markenbewertung nach dem Interbrand-Ansatz, pp. 440 et seq.

524 Stucky, Interbrand-Modell, p. 125.

525 Künzel, Die Marke und ihr Wert, p. 132; Stucky, Monetäre Markenbewertung nach dem Interbrand-Ansatz, pp. 443-446.

526 Stucky, Interbrand-Modell, p. 117.

527 Ibid., p. 119.

528 This function is said to have been developed on the basis of Interbrand-internal empirical studies on the risk behaviour of brands, cf. Stucky, Interbrand-Modell, p. 122. 
total value of a brand for a market segment, these NPVs and a perpetuity representing the fact that the valued brand will probably exist beyond the forecasting horizon are added up. Finally, such brand values calculated for each segment can be summed up in order to attain total brand value.

For "Die Tank AG", Interbrand identified a brand strength score of 44, which resulted in a discount rate of $9.35 \%$. The brand-specific earnings estimated for the years 2003 to 2007 were discounted with this interest rate and then added, the result of which was $€ 66.49$ million. As Interbrand supposes that a brand generally has an indefinite lifespan, a perpetuity of $€ 155.17$ million was added, which resulted in a total value of the brand segment "Oil" of $€$ 221.66 million. With the values of the segments "Wash" and "Shop" added, the total value of the brand "Die Tank AG" was calculated to be $€ 463$ million. ${ }^{530}$

To Interbrand's credit, they have developed one of the first brand valuation methodologies operating from a holistic point of view. ${ }^{531}$ By marketing it successfully, ${ }^{532}$ they have indirectly contributed to making such tools more attractive and to raising their acceptance level.

A further positive aspect is the fact that Interbrand attempt to handle the complex holistic character of brands by involving a number of different value determinants. This, on the one hand, lowers the probability of omitting important value influencers and thereby reduces risk. The more various facets of brand value are operationalised, the more important information will be gained, which reduces asymmetry of information and risk.

On the other hand, the threat of including overlapping and correlating criteria is thus relatively high. However, point score methods like the Interbrand one function with the assumption that all utilised criteria, which are added up to a total point score, are independent of each other. In fact, this tool does for example not allow for separate treatment of product and brand related factors. Yet such separation is necessary since market leadership does not necessarily depend equally on both factors. It may well be brand indepen-

529 Künzel, die Marke und ihr Wert, p. 134; Stucky, Monetäre Markenbewertung nach dem Interbrand-Ansatz, p. 447.

530 Stucky, Interbrand-Modell, p. 124.

531 Künzel, die Marke und ihr Wert, p. 135.

532 Especially by the ranking of the 100 most valuable global brands which they issue annually in cooperation with the business magazine BusinessWeek, cf. e.g. http://ww w.interbrand.com/best \_brands \_2006.asp (last accessed March 28, 2007). 
dent. ${ }^{533}$

What is more, even though Interbrand operationalise more criteria than others, they as well do not include all various kinds of criteria necessary. For example, consumer behavioural factors like brand sympathy, which are needed for purposes of efficient brand management, are not sufficiently considered. ${ }^{534}$

In addition, transparency and replicability of this methodology are lacking at a number of stages. For example, it is not comprehensible how the scurve utilised in step four (the same curve is used in every valuation) is actually arrived at and whether it is valid. In addition, the criteria used to operationalise the seven factors in the course of the brand strength analysis are not completely disclosed. ${ }^{535}$ The Interbrand methodology is thus to some extent an inflexible and 'black box', i.e. intransparent or opaque, tool. Hence, the criterion of conceptual and methodical soundness is merely met in part.

While the Interbrand model attains the highest market share of all hybrid proprietary brand valuation tools, its market share is far behind compared to hybrid generic and most other ones. The prerequisite of widespread acceptance can therefore only be said to be met in view of hybrid proprietary brand valuation tools, which merely constitute a small fraction of all methods available.

A positive aspect of the methodology at hand is that future orientation is covered by both discounting estimated future income streams and handling a few non-financial factors such as brand trend, which includes attributes like future developments and prospects. ${ }^{536}$

However, comparability of results, a further prerequisite for attaining a manageable valuation outcome, is not achieved by the Interbrand tool. This is due to the fact that this tool is per se not applicable to all kinds of brands (let alone other IP assets). It is solely applicable if the proprietor company is publicly traded, earns at least one third of revenue outside its home country, EVA is positive, the brand is market facing and does not have a purely business-to-business single audience without wider public profile and aware-

533 Künzel, Die Marke und ihr Wert, pp. 137-139.

534 Ibid., p. 138.

535 Bekmeier-Feuerhahn, Marktorientierte Markenbewertung, pp. 78-81.

536 Stucky, Interbrand-Modell, p. 117. This is an improvement compared to the ACNielsen technique, one of the shortcomings of which lie in the lacking operationalisation of future-related value influencers. 
ness. This means that brands such as Mars, which is privately held, cannot be valued. ${ }^{537}$ Neither can young brands, since they usually do not bring about a positive EVA. ${ }^{538}$

All in all, even though the Interbrand brand valuation tool comprises noteworthy advantages, the list of drawbacks prevails. Especially the partially lacking replicability and missing applicability for all types of brands make it a methodology which cannot be recommended for widespread utilisation.

\subsubsection{Intermediate Findings}

Brand Performance System, like Interbrand Brand Valuation, combines both financial and non-financial value parameters. However, underlying priorities are different. Whereas Interbrand's methodology originates from financeoriented valuation uses such as accounting and focuses on the net present value of future income streams as representing utility of the brand and therefore its value, ${ }^{539}$ ACNielsen defines brand value more holistically, ${ }^{540}$ operationalising brand strength as the target figure resulting from brand value. ${ }^{541}$

The various non-monetary factors playing a role within the Interbrand methodology cover brand value more comprehensively than those operationalised in the course of ACNielsen Brand Performance System. For example, contrary to the latter, legal trade mark protection is one of the seven non-monetary factors being examined in the course of the fourth valuation step of the Interbrand methodology. ${ }^{542}$ On the other hand, ACNielsen achieve a better result with respect to separation of brand and product related success factors than Interbrand. However, the issue of overlapping criteria has been resolved by neither of these methodologies.

Interbrand/BusinessWeek, Best Global Brands 2006. A Ranking by Brand Value, p. 9.

538 Berger, MarkenR 1999, 271, 275.

539 Stucky, Interbrand-Modell, pp. 103-104.

540 Following Domizlaff's 'Markentechnik' ('brand technology') approach, defining a brand as a "system in which people and objects, mind and matter are linked to become one and interact", cf. Franzen, ACNielsen Brand Performance System, p. 129.

541 Franzen, ACNielsen Brand Performance System, p. 129.

542 Determinants of legal trade mark protection, such as the type of registration or the number of won or lost cases, are allocated $5 \%$ of overall importance of the seven factors, cf. Stucky, Interbrand-Modell, p. 117 and Zednik/Strebinger, Marken-Modelle der Praxis. Darstellung, Analyse und kritische Würdigung, p. 133. Yet all legal points playing a role in this context are not completely revealed. 
Contrary to financial or customer-related valuation tools, which per se do not claim to allow for comprehensive valuations, hybrid methodologies aim at doing so and therefore need to be assessed in light of this goal. They can, hypothetically, be expected to meet all three requirements of an ideal valuation technique. Such techniques are theoretically capable of providing systematic and comprehensive valuations, as they seek to combine both quantitative financial (usually based on the income approach) and qualitative psychographic (generally operationalised by means of indicators) value elements. Such modus operandi can lead to manageable valuation output and widespread acceptance of the valuation technique. Hybrid tools are therefore, by concept, much better equipped to resemble or even to constitute an ideal valuation method, as defined in this work, than financial or customer-related techniques per se will ever be.

However, both hybrid methodologies discussed here merely meet the requirements of conceptual and methodological soundness, widespread acceptance and manageable output in part, each with a different focus. Despite a number of good elements, considerable shortcomings still exist. The methodologies use varying numbers of qualitative indicators, yet fail to treat all important aspects. The risk of overlapping value factors is not always sufficiently mitigated. The transfer of qualitative value parameters into quantitative monetary figures, one of the core issues of hybrid valuation tools, is carried out in various ways. Here, most modi operandi are left obscure to some degree, which hinders transparency and replicability.

\subsubsection{Conclusions}

The status of currently offered and applied brand valuation methods is characterised by a dichotomy. On the one hand, there are generic financial and psychographic methods which, although acceptedly of limited suitability with respect to reaching holistic valuations, attain highest market shares (they meet the demand of simple valuations focussing on one issue as, for instance, applied in brand management, such as determination of the strength of one's own brands vis-à-vis competitors'). On the other hand, hybrid methodologies, which all seem to be proprietary, hold the potential to be much better suited for purposes of comprehensive brand valuation, yet their market share is inversely proportional to that potential. 
This is mainly due to two factors. Firstly, each of these methodologies seem to contain at least one substantial methodical flaw, for example the omission of important value-influencing factors. This causes none of these tools to be wholly convincing. Secondly, central processes within proprietary hybrid techniques are often inflexible and not made transparent, thus constituting 'black boxes'. This impedes the necessary degree of replicability of and trust in such methodologies which would bring about greater market shares.

Hence, one of the main reasons why hybrid brand valuation tools have not yet been accepted more widely is that, in many cases, the additional quality they could add to the valuation process has not been realised so far. This circumstance causes many experts to refrain from allocating financial resources to such a valuation. It seems that, for many valuation scenarios, currently offered proprietary hybrid tools are not worth the investment compared to freely available generic ones.

\subsection{Summary and Outlook}

In the following, the most important brand valuation aspects, developments and trends derived from above analyses will be illuminated. Lessons to be learnt from these circumstances will be discussed.

\subsubsection{Important Brand Valuation Developments and Issues}

As seen above, business leaders have come to realise brands are oftentimes the most valuable assets in the company. ${ }^{543}$ However, there remains considerable discord with respect to the degree of significance to be allocated to brand valuation and how such valuation is to be carried out. This is mirrored by the current implementation gap: roughly $40 \%$ of all German companies with brands value these at all. ${ }^{54}$ This fact shows not only a detrimental situation for brand valuation service providers, but primarily that brands are neither managed nor leveraged as assets to their full potential.

This partial abstinence from brand valuation is mainly rooted in the belief that there exist no suitable valuation tools rather than the opinion that

544 See above at 3.1.1. 
such valuation is neither needed nor beneficial. Even though there are more than 300 brand valuation methods available worldwide, none has achieved sufficient approval rates reflecting the necessary degree of trust which would help close the presently existing implementation gap.

Despite a quantitatively significant supply of proprietary brand valuation tools on the German market, a stable trend shown by a number of studies indicates that generic financial and customer-related methods are by far the most widely applied in practice. Compared to these, proprietary ones attain rather small market shares.

Generic valuation methods bring about - through their free availability both full transparency and maximum cost efficiency. These are major advantages vis-à-vis proprietary tools. Brand managers are able to detect benefits and detriments of each method with little effort. They can therefore apply such methods as they deem appropriate and at relatively low cost, which to some extent compensates the fact that these techniques are of limited applicability. ${ }^{545}$

Proprietary tools are mostly hybrid in nature. ${ }^{546}$ This effort to combine elements of financial and psychographic valuation methodologies is commendable, since all such factors are important value drivers or distractors. Therefore, in theory, the market share hybrid valuation tools attain should be substantially higher than it is at present.

There are, effectively, two reasons why distribution rates of such tools are still low: intransparency and lack of quality. First and foremost, even though a number of these tools are being sufficiently advertised, the fact that they are essentially kept secret plays a main role in causing reluctance of having them applied. The fact that the quality of hybrid proprietary methodologies is merely verifiable to a limited degree has not convinced most brand practitioners up to now. Secondly, despite commendable operationalisation of both qualitative and quantitative value factors, to varying degrees, this is not carried out in a fully comprehensive and coherent fashion.

The belief that there exists no suitable brand valuation technique is therefore justified to a considerable extent. It seems that, at least from a brand practi-

545 For example, the analysis of psychographic indicators can provide valuable information for brand positioning in a specific situation yet is not able to provide the appraiser with a holistic financial value outcome needed for budget allocation and other purposes.

546 Furthermore, all hybrid methodologies seem to be proprietary. 
tioner's point of view, a possible added benefit of proprietary hybrid methodologies vis-à-vis generic tools, justifying allocation of resources to mandate valuations using such tools, is not existent or not high enough respectively.

Ultimately, all current monetary brand valuation methods (i.e. those with an outcome expressed in monetary terms) attempt to reflect an uncertain future in a financial figure on the basis of a fragmentarily comprehended present. ${ }^{547}$

This situation is not likely to change in the near future. Not until comprehensive, coherent and (more) transparent ${ }^{548}$ brand valuation tools will be offered at competitive prices will the market allow for the best suitable methods to become widely utilised and trusted.

\subsubsection{First Steps Towards a Possible Solution}

The facts that the valuation methods and methodologies in use at present all have at least one serious flaw and that none is valid for all valuation situations causes a number of scholars and practitioners to recommend using several methods on one IP asset at a time. ${ }^{549}$ Some suggest that it is best practice today to use as many valuation methods as possible to arrive at a reliable value outcome. ${ }^{550}$ By aggregating multiple methods, a range of values or a weighted value can be arrived at. Some writers propose this solution but caution the valuator against taking a simple average. ${ }^{551}$ Furthermore, it is advised to use a synthesis of several valuation methods in order to validate one of them. For example, a cost-based method could be applied in order to counter-check the result reached using an income-based method. ${ }^{552}$

Any of such procedures, however, would be logically incoherent due to a number of reasons. First of all, application of two or more questionable valuation methods or methodologies instead of just one does not improve the quality of valuation process and outcome. Such approach will not be able to provide the appraiser with more comprehensive and useful results than its component

547 Strebinger, Markenartikel 2005, 37, 38.

548 The author acknowledges the need for proprietary valuation techniques to be kept secret to some degree, yet as of today there is potential to increase acceptance of such tools by revealing more information.

549 Cf. e.g. Anson/Suchy, Fundamentals of Intellectual Property Valuation: A Primer for Identifying and Determining Value, p. 37.

550 Cf. e.g. Woodward, Valuation of intellectual property, p. 2.

551 Gream, Trademark valuation, p.14.

552 Ibid. 
methods. It rather entails a more time and cost consuming valuation procedure and leaves the appraiser with the problem of having to deal with several questionable value figures instead of one. In short: several value outcomes of limited or lacking usability are not better than one. Secondly, a number of diverging outcomes would have to be dealt with and merged into one. This would constitute a further step which brings about possible pitfalls as it is unclear how the outcomes should best be treated, for example weighted and merged.

Applying many inconsistent methodologies instead of one therefore does not add quality to the valuation process. It would rather be more economical and reasonable to use one single flexible and comprehensive technique which takes all due factors into account but omits as many flaws entailed by current methodologies as possible.

One central circumstance such a methodology would have to handle in the course of future-related, strategic valuations is that the future is always uncertain. Every valuation, therefore, by definition involves guesswork. Hence, there is no such thing as an accurate future-related valuation. This is a reality which must be accepted with respect to any valuation object, be it a tangible asset such as a house or an IP asset, for example a patent. It is therefore crucial not to make higher demands on the valuation of IP assets than on the valuation of other assets which is already more established and recognised, such as real estate or bond valuation.

Instead of representing the uncertain future on the basis of a fragmentarily understood present, one needs to change understanding of the present for the better. Hereby, it is expedient to begin the train of thought with the general and end at the specific. Transferred to valuation of intellectual property assets, this means that one should first of all work out value-determining characteristics all assets (tangible and intangible) have in common. Using findings herefrom as a basis, one can subsequently work out specifics pertaining to IP assets. Such modus operandi avoids the risk of focussing on detailed characteristics of IP assets too early, thereby overlooking fundamental and basic coherences of value and valuation. ${ }^{553}$

As worked out in chapter one, scarcity, utility and title are constitutive factors

553 This is the reason why important fundamental value-related issues pertaining to intangible assets have been elaborated in this work before attention has been turned to IP assets, particularly trade marks, and related brands. 
of value of any asset. They therefore need to be operationalised in every comprehensive valuation tool.

Furthermore, in the light of the definition of monetary (brand) value given in chapter two, ${ }^{554}$ reduction of asymmetry of information and therefore of risk is also fundamental to a value finding process. This can be achieved through operationalisation of as many qualitative and quantitative factors as possible in the light of keeping the valuation process coherent and clear. Such factors need to represent all actualities which have a bearing on value. These include not only financial issues but also legal, business strategic and technical conditions. These information-gathering factors can deal with both general questions of value and issues specific to the intellectual property asset under assessment.

A flexible and comprehensive valuation tool thus outlined will be introduced in the following chapter. 


\section{Chapter 4}

\section{A Systematic Integrated Valuation Methodology}

The preceding chapters have shown that there are fundamental coherences pertaining to intellectual asset and intellectual property valuation. By necessity, any comprehensive IP valuation methodology needs to take them into account. Also, such methodology should reflect thorough understanding of specific nature and value-related characteristics of the valuation object.

As elaborated in the preceding chapter, current brand valuation techniques do not fulfil these and other requirements to a satisfactory degree. This lack of quality is a main reason for the extent of practical application of brand valuation falling short of its perceived importance.

The author's own ${ }^{555}$ systematic integrated intellectual property valuation methodology (or SIM) has been designed to help close this implementation gap. It will be introduced in the following. It has been created specifically with the abovementioned goals in mind and will, like the valuation tools in the preceding chapter, be verified against the requirements a forecasting valuation technique must meet. ${ }^{556}$

\subsection{Overview of the Valuation Process}

In order to achieve the objectives just outlined and set forth in previous chapters, the SIM has been designed as a business process-like valuation

555 Developed in co-operation with Mr. Paul G Fairhurst, whose research focus is on the valuation of patents.

556 Cf. 1.4 . 
methodology. Building upon existing positive features of the current state of the art of brand valuation, it uses a commonly accepted financial method as a starting point within the first step of the valuation process, the financial income-based analysis. A contextual, qualitative evaluation process (named 'prismatic evaluation') is applied as a second step in order to arrive at a comprehensive value outcome which can be expressed in monetary terms.

\subsubsection{Financial Income-Based Analysis}

For most strategic valuation scenarios, a monetary value outcome is desired. Therefore, a financial component needs to be applied by the respective valuation tool sooner or later. The income approach is such a financial element. It is the component of the SIM to be applied initially, in the form of a discounted cash flow and decision tree analysis.

\subsubsection{Income Approach, DCF and Decision Tree Analysis}

According to the income approach, the value of an asset lies in the sum of the estimated future income streams which can be derived directly from it. ${ }^{557}$ As set forth above, it is, despite its shortcomings, a widely accepted valuation tool with good reason. ${ }^{558}$ Out of the three basic and traditional financial valuation approaches, it is the most apt one for use in valuations for strategic purposes, because it is future-oriented and focuses on a crucial factor of value of an asset: its ability to create revenue. It would not be comprehensive enough as a sole valuation tool, as it does not consider qualitative contextual value influencing factors. ${ }^{559}$ However, as a starting point or first step respectively it is expedient to be used.

The reason why the SIM applies the income approach initially and not after the qualitative evaluation is clarity. As every future-related monetary valuation must, since it constitutes an estimate, by necessity arrive at a value spread instead of a fixed outcome, ${ }^{560}$ it appears to be more logical to first of all establish the spread by a monetary means (income approach, DCF and decision tree analysis) and to subsequently (using the value spread as a basis)

557 An explanation of this definition can be found above at 3.2.2.1.3.

558 Supra, 3.2.2.1.3 and 3.3.2.

559 Above at 3.2.2.1.3.

560 Cf. e.g. supra, 1.2. 
compute a most likely expected value, based on a more comprehensive, contextual qualitative evaluation process. Thereby, the qualitative evaluation, which distinguishes the SIM from other valuation tools, can be used to its full potential, since usefulness of the end result increases with a decrease of the size of the value spread. ${ }^{561}$

As the income approach per se merely states that the sum of all future income streams derived exclusively from the asset (in their expression at the prospective time at which they are estimated to accrue) equals its value, it does not allow for expression of these streams in terms valid at the time of valuation (it is fragmentary anyway, as it merely constitutes an approach and not an adequate method or methodology). Hence, it needs to be combined with the discounted cash flow (DCF) method, which allows the future income streams to be discounted to a net present value (NPV) ${ }^{562}$ It follows that the income approach, combined with the DCF method, allows the respective estimated future income streams to be expressed in monetary terms as of the time of valuation - a step indispensable for every valuation seeking a monetary outcome. How this is carried out has been elaborated in detail in chapter three, ${ }^{563}$ which shall be referred to at this point instead of reiterating this information here.

For purposes of the SIM, the DCF calculation is combined with a decision tree analysis. This enables the valuator to take different estimated risk scenarios into account - an important advantage with respect to intellectual property rights the value of which is strongly influenced by a number of risk factors. ${ }^{564}$ A decision tree allows the appraiser to run through a best and a worst case scenario (and more possibilities if so wished), arriving at a minimum of two financial values representing these scenarios. Hence, it is a proper tool to define the financial value spread.

The actual calculation steps of any discounted cash flow and decision tree analysis are the same, in whichever context they are applied. What differentiates the SIM greatly from other IP valuation tools is the instance that it

561 This modus operandi may not be the only one in order to arrive at a high-quality end result in the course of a strategic IP valuation. However, it combines an established instrument with a newly developed one in a logical and practical way which allows the valuator to arrive at a comprehensive and highly useful outcome.

562 Cf. 3.2.2.1.3.

563 Above at 3.2.2.1.3.

564 For more background information and on how a decision tree analysis is carried out, see supra at 3.2.2.1.3. 
specifically uses such financial analysis in order to assess the obligatory value spread and that it merely applies it as a first step which it supplements with a qualitative analysis in a unique fashion.

How the value spread is determined by means of income approach, DCF and decision tree analysis will be explained in the following.

\subsubsection{Assessing the Spread}

One can distinguish two subgoups of forecasting valuation scenarios: situations with two or more parties, such as licensing negotiations, and those in which value is seen merely from one viewpoint, for instance evaluation for resource allocation purposes within the respective company.

\subsection{One-Party Scenarios}

In a unilateral valuation situation, a value spread is defined by a best case and a worst case figure - the highest and lowest value respectively. Hence, income approach, DCF and decision tree analysis must be applied (at least) twice, that is to arrive at a financial figure representing the estimated best case scenario and one standing for the estimated worst case. ${ }^{565}$

Assessing the Spread - One-Party Scenarios

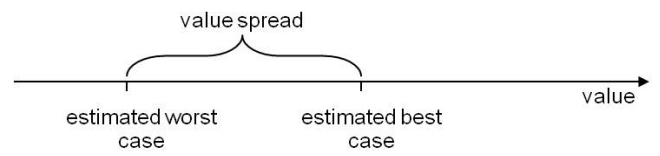

Figure 4.1: One-Party Scenarios.

\subsection{Two- or Multi-Party Scenarios}

In the course of a scenario involving two or more parties, each side assesses the respective brand or IP asset from their perspective in any event, which results in at least two (usually diverging) conceptions of value. For tactical reasons, the parties are unlikely to communicate to the other the outcomes of their DCF and decision tree analyses. Rather, a potential buyer or licensee

565 How such a calculation is carried out in practice is described in detail above at 3.2.2.1.3 and will therefore not be reiterated here. 
will, for instance, communicate an initial lowest price or royalty rate, based on the financial analysis, knowing that he will probably have to accept a higher amount by the end of the negotiations. Correspondingly, a potential seller or licensor will, along the lines of his DCF and decision tree analysis, specify a higher amount than he can reasonably expect to be the end result of all subsequent negotiations.

The success of these negotiations depends on whether the spread between these two figures constitutes a possible overlap, or 'gain to be divided', and on the manner in which actual negotiations are carried out (ideally in a way enabling the parties to appropriately share this gain). The SIM can be a decisive support in this regard.

For instance, a seller may want to sell for at least $€ 50,000$ and a buyer may wish to acquire for a maximum of $€ 60,000$ (cf. figure 4.2 example 1 ). In this case, there is a negotiable overlap between $€ 50,000$ and $€ 60,000$. However, it may well be that a buyer may initially wish to close a deal for no more than $€ 50,000$, whereas a seller demands $€ 60,000$ (figure 4.2 example 2 ). In this case, there is, at least after this first rough valuation step, no gain to be divided.

\section{Assessing the Spread - Two-Party Scenarios}
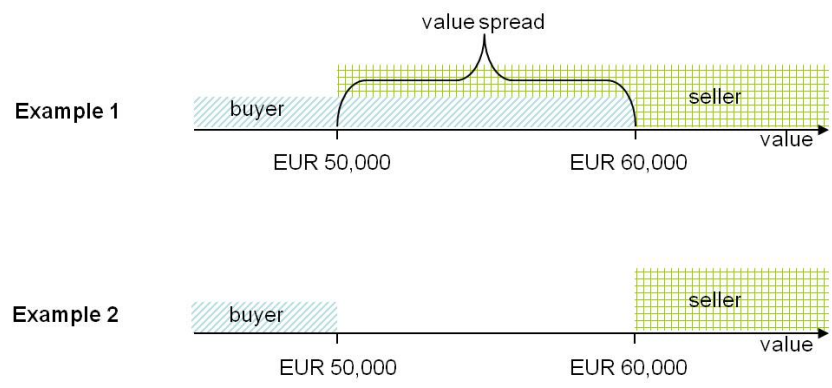

Figure 4.2: Two-Party Scenarios.

In the course of the former alternative, it is already apparent after the financial analysis that the parties are most likely to close a deal for an amount anywhere within the value spread. In the latter case, it remains to be seen whether they are going to find consensus eventually. This depends largely on whether the parties are going to find information on the asset previously unknown to them - information which is able to change their initial value estimates. 
In the course of both alternatives, the SIM can provide significant negotiating guidance, especially since the step following the financial analysis, the prismatic evaluation (which will be discussed in detail hereafter at 4.1.2), enables the valuator to comprehensively collect information on legal, technical, business strategic and financial value-influencing factors. This enables the party having mandated the valuation to negotiate and decide on a well-informed basis.

It follows that a value spread is reached in the course of every forecasting valuation scenario, be it a one-, two- or multi-party setting. This spread is a first rough approximation to the asset's value after DCF and decision tree analysis.

At all events, and whether or not the value spread consists of a gain to be divided, this first version of the value spread is a suitable starting point to be substantially refined by the subsequent step, the prismatic evaluation.

\subsubsection{Intermediate Findings}

A financial income-based assessment comprising DCF and decision tree analysis constitutes the first of two major parts adding up to the Systematic Integrated Methodology. As a widely applied tool in the course of many different types of valuations, it serves, within the SIM, as an easy-to-use means of computing a first purely quantitative version of the inevitable value spread. At the same time, it enables the methodology to reach a financial value outcome. In the course of two- or multi-party settings, this calculation step helps systematise the negotiation process.

Such a financial analysis, as a sole valuation tool, would be too narrow and inflexible for purposes of forecasting valuations. However, it serves as a proper starting point to be complemented by a comprehensive contextual process operationalising qualitative value factors - the prismatic evaluation.

\subsubsection{Prismatic Evaluation}

The way in which a valuation tool is able to deal with future-related uncertainty and risk while providing comprehensive and reliable process and outcome is decisive for the quality of both the tool and the valuation result. Therefore, the treatment of the rough value spread by means of the second 
step, the prismatic evaluation, ${ }^{566}$ constitutes the central and unique component of the SIM. Contextual variables are operationalised by means of a scoring system, the outcome of which is utilised to close the information gaps the purely financial first step inevitably leaves.

The monetary value spread resulting from the financial analysis merely constitutes a first rough value estimate. This is due to the fact that income approach, DCF and decision tree analysis solely operationalise one type of financial data, albeit an important one: expected future income streams derived exclusively from the asset. However, in order to arrive at a valuation outcome which reflects reality as closely as possible, it is indispensable to include as much useful information as possible and feasible, financial and nonfinancial, quantitative and qualitative, in the valuation process. The more information the appraiser is able to collect with respect to the IP asset in question, the better will he or she be able to assess both its characteristics, opportunities as well as risks pertaining to that asset. All these factors greatly influence the value of an asset in a forecasting context. The above definition of financial (brand) value ${ }^{567}$ can thus be approximated as closely as possible.

In the course of the SIM, such approximation is achieved by means of the prismatic evaluation. It is a means to reliably collect qualitative and quantitative contextual information and incorporate it into the valuation process.

One can distinguish four groups, or dimensions, of characteristics common to all IP rights (and all other assets as well) - legal, ${ }^{568}$ technical, business strategic and financial. ${ }^{569}$ Each of these so-called 'four dimensions of value' is analysed separately before the four single results are combined to one intermediary contextual score, which is subsequently merged with the value spread outcome from the financial analysis, arriving at a contextual valuation end result.

566 This process has been named 'prismatic evaluation' as it can be exemplified by means of a ray of light fed through a prism. The intellectual property right in question is being represented by a white ray of light which the prism separates into four rays of complementary colours - the so-called 'four dimensions of value'. These dimensions are then separately analysed. The results are subsequently combined, that is fed back into a prism, which produces a contextual end result or white ray of light representing the evaluated IP asset.

567 At 2.2.2.1.

568 For purposes of adequate priority setting, the legal dimension will be specifically focussed on and set out in detail in the following chapter.

569 See above at 3.3.2. 


\subsubsection{Compilation of the Four Dimensions of Value}

The SIM is not the first brand or intellectual property valuation tool which combines a financial analysis with qualitative contextual components. However, it provides all means necessary in order to systematically and flexibly process a number of important value influencers which is large enough to include all critical issues yet small enough to keep the workflow transparent and efficient.

In the light of the fact that there are value influencing characteristics common to all assets, characteristics common to intellectual property assets and those specific to each type of IP asset, the four dimensions have been designed to cover such general and specific value influencers. Instead of being bound to working with the same indicators in every case, independently of whether that indicator may be important or not in the particular situation, the appraiser is free to choose adequate topics (legal, technical, business strategic and financial ones respectively) within each dimension, depending on the respective asset under valuation and on other factors such as the valuation cause.

As elaborated above, ${ }^{570}$ intellectual property rights' scarcity, a fundamental requirement for an asset's potential to develop a value, is established by legal protection (provided that secrecy - an option for patents rather than for trade marks - has not been chosen). Furthermore, next to existence of a legal protection system as a whole, there are several legal issues the existence or failure of which respectively can be decisive for the particular IP asset's value. Scope of protection or the possibility of alienation of an IP right ${ }^{571}$ are good examples in this regard. Hence, legal issues must be included in any holistic value assessment of an IP right. ${ }^{572}$

Secondly, technical issues are of vital importance as well. This may at first glance be more apparent with respect to patents than brands. Technical factors which are important in the course of patent valuation include all those value-related questions which pertain to the patented technology, such as the

$570 \quad$ At 1.3.1 and 2.1.1.3.7.

571 As to transferability of brands, particularly the trade mark part of brands, cf. supra at 2.3.2.1. Other trade mark law issues and their possible effect on brand value will be discussed in chapter five.

572 Fezer, $\S 27$ MarkenG at no. 59, comes to the same conclusion, stating that the valuation method needs to accomodate the concrete legal relevancy of the brand's value, without providing further detail. 
issues whether the technology is part of an industry standard or whether it is bleeding edge, leading edge or behind the curve. In analogy to this, technical brand aspects include questions pertaining to the branded product or service, such as quality and uniqueness. Furthermore, one needs to keep in mind that the 'marketing bundle' brand, not the IP right trade mark, is at issue. As explained above, ${ }^{573}$ a brand contains one or several trade marks and additional marketing elements which impact brand value as well (brand awareness, image and identity). These elements are best dealt with under the heading 'technical dimension'. This is not only the case because they would be out of place in any of the other three dimensions, but particularly since the technology of a brand, i.e. the way it functions, can only be aptly dealt with on the basis of its components. ${ }^{574}$ Therefore, in addition to the patent valuation analogy just outlined, the technical dimension of brand value needs to deal with brand specific elements such as brand awareness and customers' associations with the brand.

Business strategic factors comprise all those issues pertaining to the strategic role of the respective brand within the business as a whole. These include, amongst others, the questions whether the brand belongs to the core competence of the business and whether the proprietor duly applies necessary resources to exploit the brand to its fullest potential. In addition, it could be of importance to examine local business and political conditions. ${ }^{575}$

Last but not least, financial matters include issues such as production and brand management costs (including marketing and legal protection cost, like registration and attorney's fees), marginal cost and its expected development and return on brand investment. The amount of potentially paid prior royalties also plays a role in this context.

Taking these four groups of characteristics into account cannot guarantee that

573 At 2.1.2.2 and 2.1.2.2.1.

574 Not without cause do acknowledged scholars concern themselves with 'brand technology' ('Markentechnik'). Hans Domizlaff, a deceased yet still well-known German brand specialist and artist, had already coined the term 'Markentechnik' in the first half of the 20th century, cf. Harte-Bavendamm, GRUR 1998, 335, 335. For more on 'brand technology' cf. e.g. Deichsel, GRUR 1998, 336.

575 In some jurisdictions, it may, for instance, be legally and/or factually impossible or at least very difficult to run a (joint venture) business in certain industry sectors or independently of governmental intervention. For example, the current Chinese Catalog for the Guidance of Foreign Invested Enterprises (Revised 2007) lists "encouraged", "restricted" and "prohibited" categories of foreign investment, cf. Dickinson, Breaking News: China Changes Foreign Investment (FDI) Rules. 
every factor which may be important is included. However, it will provide the valuator with a comprehensive tool which, if properly handled, makes sure that no important value-impacting factor is overlooked and a realistic degree of comprehensiveness and accuracy is reached with respect to the end result. This sets the SIM apart from other hybrid methods which, for example, merely combine financial and psychographic factors.

Next to comprehensiveness, the objectives for and advantages of breaking down the value influencing issues into four dimensions are systematisation and risk reduction. The breakdown into the four dimensions, as well as the process of selection of the points to be dealt with in each dimension which will be introduced shortly, mitigate risk of possible overlap of these points. Furthermore, being able to assess the dimensions separately guarantees that the valuation process is manageable and ensures a systematic approach towards it. What is more, it enables the appointment of an expert in each field (legal, technical, business strategic and financial) to evaluate one dimension separately in the course of every valuation at issue. This means that the respective experts are able to exclusively focus on what they do best, applying and developing an unbeatable degree of experience. At the same time, the risk of subjectivity is spread since not one but four persons are working on the evaluation. The fact that some persons may see things more strictly than others will be levelled out to a considerable degree by this process. If merely one person took care of the whole valuation process, the outcome would be far more skewed by subjectivity.

For these reasons, the four dimensions of value have been developed to constitute the central component of the Systematic Integrated Methodology. Each dimension needs to be filled with suitable issues affecting the value of an IP right (a number of examples hereof have been given in preceding paragraphs). In this connection, a balance between the objective to include as many salient value aspects as possible and the aim to keep the process as lean, manageable and cost-effective as possible must be struck.

This can be achieved by selecting no more than ten to 15 issues in each dimension. ${ }^{576}$ In order to ensure that all of these items are of comparably high importance, one should initially come up with the double amount of items, e.g. 20, and select the ten most important ones of these. ${ }^{577}$ If this type

576 This is a suggestion, based on theoretical and practical experience. However, the actual number a valuator wishes to include is at his or her discretion. 
of selection did not take place, one would have to weigh the issues against each other according to their importance, which would bring about added insecurity and/or arbitrariness within the evaluation process and be almost impossible to carry out in a satisfactory way (apart from the fact that it would be rather time consuming).

Attention also needs to be given to the fact that - since all issues in all dimensions must be of comparable weight in order to prevent having to weigh the dimensions as such against each other - the number of items selected to be operationalised should, in general, be the same for each dimension. ${ }^{578}$ This means, for instance, that each dimension should contain 15 items. Thereby the dimensions will be comparable and of equal weight. This is crucial for purposes of the following comparative evaluation, in the course of which the results of assessment of the dimensions will be combined with the outcome of the financial analysis.

The fact that number and content of issues dealt with in the course of the prismatic evaluation may vary provides users of the SIM with a high degree of content-related flexibility, if required, both in a specific situation and over time. However, taking advantage of this flexibility only makes sense if it is balanced against consistency. A reliable, i.e. reproducible, valuation technique $^{579}$ can only be put into practice if the processed items are changed as little as possible and as much as necessary from one valuation to the next.

Having selected an appropriate number of value influencers for each dimension, the next problem to solve is the semantic format in which these items will be prepared for scrutiny by the respective expert. Posing closed questions, e.g. questions which allow for a 'yes' or 'no' answer only, entail the problem that the outcomes would not be very meaningful, since possible nu-

577 This is not a patent remedy for achieving total equality of importance of all issues included in the dimensions. Total equality is desirable but impossible to achieve in the course of any valuation methodology dealing with more than one qualitative factor. Hence, what one should strive for is a realistic degree of equality or comparability which can be achieved by means of the modus operandi just illuminated.

578 As explained in footnote 578, the SIM can be adapted to prevent midpoint tendency by allowing the experts to answer "Do not know". The respective fact statement would then not be counted, with the consequence that the remaining statements' point scores would have to be computed as a percentage out of $100 \%$. This makes it possible to not include the same number of issues in each dimension. However, as it adds complexity to the process, it is generally recommended to keep the quantity of fact statements equal for each dimension.

579 Reliability is one of the requirements a forecasting valuation methodology is supposed to have, cf. 1.4.1.6. 


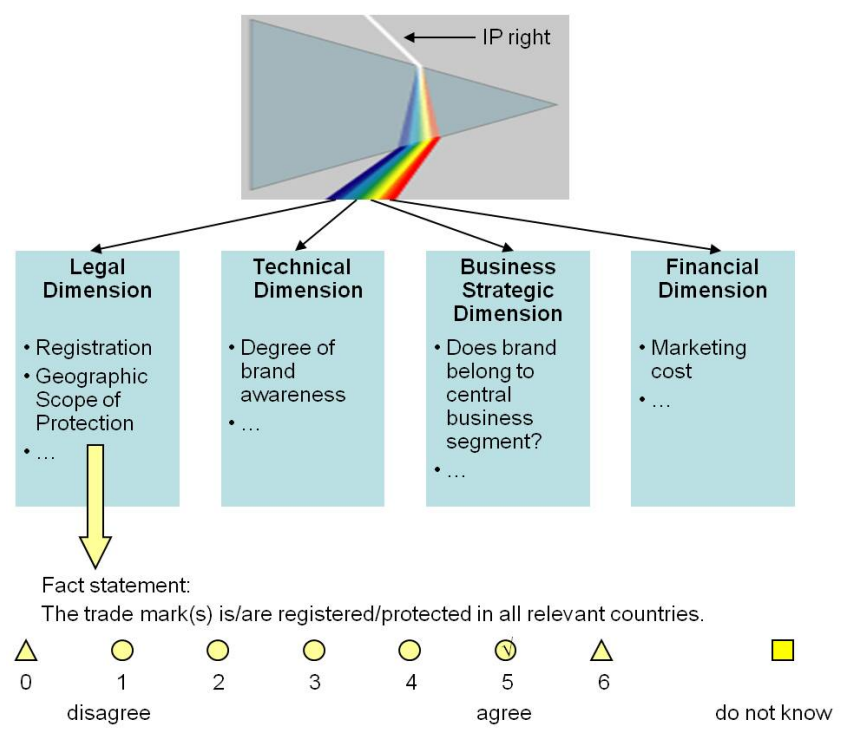

Figure 4.3: Demonstration of the prismatic evaluation from separation into the four dimensions to assessment of the fact statements. In this example, the point score for the said fact statement is five. The original version of the prism image is copyright of olypedia.de and derived from http://olypedia.de/olypedia.de:Bilder.

ances cannot be expressed. Open questions are equally not viable because answering them would be too time consuming and comparability of results would be hindered. Therefore, each point needs to be turned into a fact statement, for instance 'The trade mark(s) is/are registered/protected in all relevant countries'.

\subsubsection{Assessment of the Dimensions: Comparative Evaluation}

After selecting a suitable number of items to be operationalised within each dimension as just outlined, the items need to be evaluated. This is carried out by way of the so-called 'comparative evaluation'. It is so named since the result from this evaluation can be compared to a benchmark. ${ }^{580}$

First of all, the result in each dimension and thereafter the outcome of the

580 This is optional and will therefore not be elaborated in detail. In brief, frequent application of the SIM on assets from varying industry sectors will enable the appraiser to collect average point scores per type of asset per industry branch. The mean of these scores can be utilised as an industry benchmark the point scores from each new valuation can be compared with. Hence, the SIM will, if frequently enough applied, enable the proprietor to be up to date with respect to strategic analysis and position of the respective assets. 
qualitative evaluation as a whole (all four dimensions) need to be obtained. This is accomplished by means of a point score system. Subsequently, the point score total must be combined with the first version of the value spread resulting from the financial income-based analysis in order to reach a substantially concretised and delimited value spread as end result.

\subsection{Point Score System}

The respective expert gives his or her assessment of the fact statements in form of a score from (usually) one to five, with one meaning 'disagree' and five meaning 'agree'. Supposing there are twelve items in each dimension, the respective trade mark would normally achieve a total point score of between 48 (twelve (items) times one point multiplied by four (dimensions)) and 240 (twelve times five times four). ${ }^{581}$

The whole point scale has, however, been designed from zero to six, with zero meaning 'I disagree so much that this exceptional case is or is likely to be a deal breaker' and six equalling 'I fully agree and this issue is of such critical importance that a score mirroring a value lying above the initially envisaged value range is justified in this exceptional case'. The wording of the zero and six point score possibilities has been specifically designed in order to account for the events that, on the one hand, one negative answer of a fact statement may put the valuation result to zero or at least to a figure below the initially envisaged minimum respectively or one positive answer may, on the other hand, be so vitally important that it alone is decisive for the closing of a deal relating to the IP asset under valuation or at least shifts the value of the asset to a range above of what has originally been envisaged by means of the financial income-based analysis. In the course of an average valuation, however, the scores zero and six will normally not be found.

581 An odd number of point score possibilities has been chosen despite possible midpoint tendency, i.e. a susceptibility of an appraiser to choose the middle point score of an odd number of possibilities in case he or she is not absolutely sure what to answer. If the SIM provided for an even number of point scores instead of an odd one, it would force the respective expert to make a decision which would skew the result more. A means to decrease midpoint tendency would be to give the expert appraiser the possibility to answer 'Do not know' which would result in deletion of the respective fact statement (cf. fn. 566). As a logical consequence, in order to keep each of the dimensions' point scores comparable, the remaining fact statements' point scores, de facto resulting from 11/12 of all possible fact statements in case of 12 fact statements per dimension, would have to be calculated as out of a possible $100 \%$ score. 
Supposing there are 12 fact statements in each value dimension, the intermediary result for each dimension would normally be anywhere between 12 (twelve times one point) and 60 (or zero and 72 respectively if one looks at the complete possible range). The four intermediary results from each of the value dimensions are then merged by means of addition.

This point score total does not imply that it is the only possible result in the case at hand. As every future-related valuation is an estimate, there cannot exist merely one definite solution. Hence, the score rather stands for the most likely constellation, as duly assessed by the respective experts at a specific point in time.

\subsection{Combination with the Value Spread}

After financial income-based analysis and assessment of the four dimensions, there are two intermediary valuation outcomes: the financial value spread (as a first rough approximation to the value of the asset) and the point score. These two need to be merged in order to arrive at the final result.

This shall be explained by means of the following example and figure 4.4, assuming that the value spread computed by means of the financial analysis constitutes a 'gain to be divided' between $€ 50,000$ and $€ 60,000$ in a brand sale constellation (figure 4.2 example 1) and that the assessment of the four dimensions produced a result of 200 out of a total maximum of 288 points.

Assuming that the minimum score of zero points corresponds to $€ 50,000$ and the maximum of 288 to $€ 60,000$ would, however, be both wrong and a fiction, since no potential acquirer would be willing to spend $€ 50,000$ in case the prismatic evaluation has arrived at a zero point score - which means that the results of the evaluation of the four dimensions of value are so disastrous that the valuation object is devoid of a minimum degree of functionality. Correspondingly, in case the evaluation has revealed that the asset in question is so strong and of such exceptional quality in important aspects that a value above the originally envisaged range is justified, a deal would be highly likely to be closed for substantially more than $€ 60,000$. Hence, as set out above at 4.1.2.2.1, it needs to be accounted for the fact that these two extremes will have a monetary counterpart outside the scope of the initially envisaged value spread. After all, this first estimate of the value spread is rather rough and therefore cannot constitute a range which is 
absolutely binding in all cases. Hence, the point scores one ('I do not agree') and five ('I agree') have been designed to correlate to the lowest and highest values respectively constituting the financial value spread.

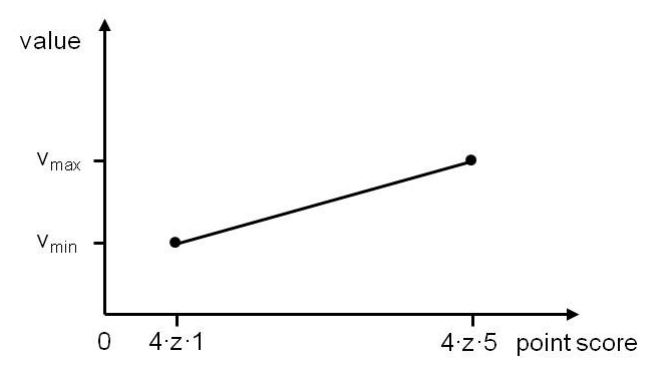

Figure 4.4: An example of combination of scoring results from assessment of the four dimensions of value with the value spread resulting from the financial income-based analysis.

In our example, therefore, the point score of 48 , i.e. the score mirroring every fact statement being answered with a score of one, corresponds to the figure at the bottom end of the first value spread $-€ 50,000$. The point score resulting from all fact statements being answered with a score of five, 240, thus corresponds to $€ 60,000$.

In order to merge the point score from the prismatic evaluation with the value spread resulting from the financial income-based analysis, the Euro amount needs to be computed which corresponds to the respective scoring result. This is done utilising the two-point form of a linear equation. ${ }^{582}$

$582 v=v_{\min }+\frac{v_{\max }-v_{\min }}{(z \cdot 5 \cdot 4)-(z \cdot 1 \cdot 4)} \cdot(x-z \cdot 1 \cdot 4)$, whereas $\mathrm{v}$ means value, $v_{\min }$ is the lowest figure in the value spread range, $v_{\max }$ the highest value in the range and $\mathrm{z}$ the number of fact statements per dimension ( $\mathrm{z}$ is variable yet should be the same in all dimensions, cf. supra at 4.1.2.1). This linear equation is based on the supposition that all correspondents of the point scores and the associated financial value figures which lie between the point score equalling all fact statements being answered with one $(z \cdot 1 \cdot 4)$ and the point score in case all fact statements are given five points $(z \cdot 5 \cdot 4)$ are on a straight line. This solution has been chosen for the SIM for reasons of plausibility and simplicity. The assumption of linearity may have to be given up in favour of a convex curve such as a Gaussian distribution in case it turns out that there is a bias in the course of the prismatic evaluation. The prime example of such bias would be midpoint tendency, i.e. a tendency to answer a fact statement with the middle possibility (in case of an odd number of possibilitles to choose from as proposed in the SIM) if the appraiser is not sure what to answer. Such midpoint tendency can, however, be remedied not only by application of a Gaussian distribution but also by giving the appraiser the option to answer 'I do not know'. Exactly this latter possibility has been chosen in the course of the SIM, cf. above at fn. 580. Hence, as the threat of midpoint tendency is dispelled, there is no reason to apply a complex and rather complicated concave function of whatever form instead of a considerably simpler straight line function. It is therefore better to choose the linear equation as described above. 


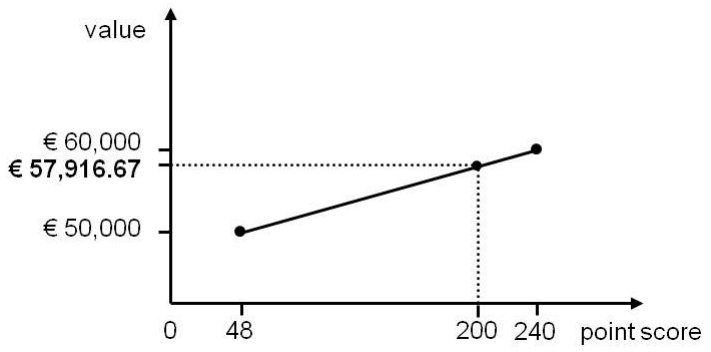

Figure 4.5: Using the two-point form of a linear equation to merge the scoring result from the prismatic evaluation with the value spread from the financial income-based analysis.

In the current example, the amount in Euros needs to be computed which corresponds to a 200 out of 288 point score, which is $€ 57,916.67$ (rounded). ${ }^{583}$

As the point score outcome of the comparative evaluation stands for the most likely value, or expected value, instead of a fixed one (every future-related valuation is an estimate), so must this result, since it constitutes a transformation of the contextual scoring result into the corresponding monetary one. It follows that, in this example, $€ 57,916.67$ is the expected value as valuation end result. It is the best approximation to the value of the asset in question as determinable by the SIM and much more reliable and useful than the initial value spread, as it reflects a thorough contextual and qualitative analysis incorporating value influencing factors from all decisive fields.

This contextual result can be scored against an industry benchmark in case a comparison with other assets, for instance other brands in the industry, is desired. In the course of the very first valuation, the mean will have to constitute the benchmark (i.e. 144 points in case of the above example), as no benchmarks will have been established from valuation yet. With every appraisal carried out, this benchmark will change and become more and more representative. Hence, the SIM will grow more accurate and even less subjective over time.

By containing both financial and qualitative analysis in this unique way, the SIM does not only provide a reliable future-related contextual value outcome expressed in monetary terms. In addition, it enables the appraiser to inform the client about important value determinants and background information collected on the basis of the comparative evaluation.

$583 v=50,000+\frac{10,000}{192} \cdot(200-48)$. 


\subsubsection{Intermediate Findings}

It is not until the prismatic evaluation, the core of the SIM, comes into play after the financial income-based analysis that contextual value influencing variables are operationalised. The process of doing so utilising the four dimensions of value constitutes a comprehensive yet flexible modus operandi.

The comparative evaluation ensures holistic treatment of legal, technical, business strategic and financial value determinants by way of a scoring model. Covering these four fields ensures that all significant factors are taken into account. This is particularly crucial with respect to highly unique intellectual property assets the utility and thus the value of which are strongly dependent on the context in which they stand (vis-à-vis other assets, within the respective company etc.).

The circumstance that the appraiser is, if required, free to choose the issues to be operationalised ensures the flexibility necessary to adapt to situations changing over time, different valuation objects and scenarios.

The monetary valuation end result produced by combining the point score with the value spread is the best possible, most likely expected value instead of a fixed one (a fixed result cannot be obtained in the course of futurerelated valuations as they are estimates). The value spread determined by the financial income-based analysis merely constitutes the outer limits of and a rough approximation to the asset's value. It is not until the application of the subsequent step, the prismatic evaluation, that a comprehensive, contextual and reliable valuation result is produced. Furthermore, the prismatic evaluation yields contextual information on the respective IP asset which relates to, amongst others, risks pertaining to the asset, elaborate information on which is an indispensable precondition for a thorough understanding of the asset's value and strategic utility.

\subsubsection{Conclusions}

The SIM, as a business tool, facilitates strategic decision making relating to intellectual property assets by providing a flexible and transparent process yielding an outcome in monetary terms, coupled with as much contextual information about the IP asset in question as possible. It therefore goes beyond the scope of a mere valuation technique in the customary sense as it 
does not only provide a monetary value outcome. It can also be utilised to strategically manage the asset under valuation, integrating it into its broader context and significance within the business and beyond.

It needs to be stressed that the SIM as introduced here cannot and does not constitute a matured valuation system. To the contrary, providing the basic and fundamental thinking and systematics as it does, it needs to be fine-tuned in practice over time in order to realise its full potential. The more often it is applied, the more reliable the benchmark becomes and the more experience the experts collect in their assessment of the four dimensions of value, being able to provide even more reliable results in less time.

\subsection{Satisfaction of Mandatory Requirements}

Mandatory requirements to be met by a desired valuation technique have been worked out in chapter one. ${ }^{584}$ As a logical consequence, they were used as benchmarks for current brand valuation tools in chapter three. Hence, the SIM also needs to be scrutinised whether it provides conceptual and methodical soundness, widespread acceptance and a manageable output.

\subsubsection{Conceptual and Methodical Soundness}

Every valuation technique is desired to be based on a sound and convincing methodical concept. With regard to strategic intellectual property valuation tools, in particular, it has been elaborated earlier that they shall be comprehensive, contextual, transparent, flexible, reliable, reduce asymmetry of information and risk and provide an appropriate degree of objectivity. ${ }^{585}$

In this connection, it is crucial to understand and draw the right conclusions from the fundamental valuation principles and coherences worked out in chapters one and two. Such insights form the conceptional basis underlying the SIM and the theoretical framework upon which it is built. The modus operandi of starting with general coherences and working out appropriate details on that foundation does not only constitute a logical train of thought but also avoids the danger of missing important valuation fundamentals. ${ }^{586}$ 


\subsubsection{Comprehensiveness}

By enabling the valuator to incluce as many issues in each dimension as he or she thinks fit (provided that, as a general rule, the number of issues is the same for each dimension), a comprehensive operationalisation of value influencers can be obtained, both with respect to quantity and to quality of these factors.

The comprehensiveness achieved does not only relate to the factors operationalised within the methodology but also to the applicability of the methodology itself. The four dimensions allow for all types of brands to be evaluated, ${ }^{587}$ no matter, for example, whether the underlying trade mark is registered or not. Furthermore, the SIM can be utilised for all types of forecasting valuations, which means that its scope of application is very broad.

\subsubsection{Context}

As mentioned throughout this work, the operationalisation of contextual issues is of utmost importance with respect to intellectual property rights as valuation objects. Unlike many other assets, mostly tangible ones, brands and IP assets are, in their utility, strength and value, relatively strongly dependent on the legal and factual contexts in which they stand, both within the respective company and vis-à-vis others. ${ }^{588}$

The prismatic evaluation enables the SIM to complement the financial income-based analysis with relevant contextual issues. These are not only financial and psychographic ${ }^{589}$ but also legal and business strategic in order to ensure a holistic view on the asset under valuation.

\subsubsection{Transparency}

A transparent valuation tool is desired in order to make it verifiable for both third parties and especially the client. This ensures both confidence in its quality and utilisation of the tool for evaluation purposes. ${ }^{590}$ However, most

586 Cf. 1.1.1.1. and 3.3.2.

587 In fact, they are even applicable on all types of asset.

588 Supra, 1.4.1.2.

589 It has become clear in the course of the analysis carried out in chapter three that a large number of brand valuation methods merely take determinants from these two areas into account. 
proprietary brand and IP valuation tools are left obscure to a relatively high degree, which impedes the possibility to understand, replicate and scrutinise them to a satisfactory extent.

By contrast, the concept of the SIM is fully disclosed in this work. Hence, the SIM does not constitute a so-called 'black box'. Such a process uses the same pre-defined set of variables for every valuation (leaving the basis for the data deployed and/or the calculation process somewhat obscure) and yields a single monetary amount as result. It may therefore be quick and tempting to use. However, as elaborated above, it is not only intransparent but also inflexible and does not give proper consideration to the fact that future-related valuations, as estimates, cannot arrive at one single fixed sum as outcome. ${ }^{591}$

\subsubsection{Flexibility}

A valuation methodology ideally needs to be able to be responsive to changes. For instance, market fluctuations or product safety problems can have immediate and strong implications on a brand's value and therefore need to be operationalised as directly and as quickly as possible in order to obtain a realistic value outcome reflecting these facts. In case the respective dimension (of the 'four dimensions of value') does not yet include an according issue, for example with regard to product safety, it can be inserted, either in exchange for an existing point which is not regarded to be important enough to still be included or in addition to existing points. ${ }^{592}$

The SIM is thus not only able to be responsive to short-term changes. In addition, it can be fine-tuned in the long run, as issues initially regarded as crucial may have turned out to be of relative unimportance whereas other points may have become important enough to be included in one of the four dimensions.

\subsubsection{Reduction of Asymmetry of Information and of Risk}

Intangible and therefore intellectual property assets are intrinsically riskier than tangible assets. Due to nontradability of the former, risk of total loss

590 Cf. 1.4.1.3.

591 Furthermore, it usually lacks the necessary degree of comprehensiveness.

592 Cf. 4.1.2.1. 
is substantially higher than with respect to the latter. Furthermore, studies have proven that return on investment regarding innovation-based assets is highly skewed. ${ }^{593}$ These issues are important value influencing factors.

Risk reduction must therefore be one major focus of an intellectual property evaluation tool. As nontradability is rooted in a substantial lack of information, gathering proper data and processing it appropriately is key. This can be achieved by comprehensively dealing with as many qualitative contextual variables as possible, thereby handling crucial value-related information. The more data is dealt with, the smaller given asymmetries of information ${ }^{594}$ become and the more closely the above definition of value ${ }^{595}$ can be put into practice.

The issue of successful risk reduction is therefore closely linked to how comprehensive the respective valuation tool is. On this note, the comparative evaluation within the Systematic Integrated Methodology as introduced above ensures operationalisation of all salient legal, technical, business strategic and financial value influencing factors. However, dealing with value influencers in a comprehensive way does not provide proper means for risk reduction unless the evaluation result itself provides all resulting information to the end user in a utilisable form. In respect of this fact, the SIM allows the appraiser to prepare all data collected from evaluation of the four dimensions for use by the client as desired.

\subsubsection{Reliability}

As set forth above, ${ }^{596}$ a decisive factor in the course of intellectual property evaluation which is often overlooked is the fact that it does not make sense to demand a higher degree of accuracy from strategic IP valuation than from such valuation of any other object. Despite accuracy is, in general, a valid objective in valuation, it can only be realised in the course of past-related assessments. Any future-oriented valuation is by its very nature an estimate which cannot result in exact value figures. Hence, it must result in a value spread, independently of whether a tangible or an intangible asset is the valuation object. ${ }^{597}$ If, thus, the valuation end result cannot be accurate,

593 Cf. above at 2.1.1.3.4, 2.1.1.3.6 and 1.4.1.5.

594 For a definition see above at 1.4.1.5.

595 Supra, 2.2.2.1.

596 At 1.4.1.6. 
it should at least be reliable. This means it should provide a reproducible process which, ceteris paribus, brings about comparable results whenever the same asset is repeatedly valued.

Since the SIM is completely transparent, the appraiser is able to ensure that the valuation process can be reproduced as desired. Hence, the high degree of transparency provided by the SIM ensures adequate reliability.

\subsubsection{An Appropriate Degree of Objectivity}

In light of the fact that every proper forecasting valuation tool must involve some degree of subjectivity (an estimate can never be absolutely objective), the crucial question is whether the valuation methodology is able to balance subjectivity and objectivity in a satisfactory way, keeping the degree of subjectivity at a minimum. ${ }^{598}$

In the course of the SIM, subjectivity comes into play both through selection of items to be included in the dimensions of value and by means of their assessment. However, the degree of subjectivity is kept as low as possible.

First of all, this is achieved by the initial selection process of the issues to be included in each dimension. This selection needs to be carried out by an expert in each field (legal, technical, financial and business strategic) and according to practical importance. The influence of subjectivity is mitigated by the fact that there are four experts involved - one for each dimension. Due to this fact, possible subjective tendencies of selection and processing of the dimensions' issues are levelled out. If merely one person was to assess all dimensions, provided he or she was an expert in all four fields, the assessment could for example tend to be relatively strict. If four persons participate, it is very unlikely that they all apply the same degree of rigour within the assessment process. Subjective influences will be compensated and thereby minimised. Hence, they will not come to light as manifestly as if merely one person was involved.

Moreover, the conception of the SIM allows it to become increasingly finetuned over time. This is due to the fact that the respective experts will build strong experience in the long run, equipping them with unprecedented

598 Cf. above at 1.4.1.7. 
ability to correctly choose and assess all relevant points. Furthermore, the more often the SIM is applied, the more accurate the respective benchmarks will become, since data from previous valuations can be utilised. ${ }^{599}$ Hence, influence of auxiliary calculations and subjectivity will decrease the more often the SIM is applied.

\subsubsection{Widespread Acceptance}

Given the fact that the SIM is presented in detail here for the first time, it cannot have gained widespread acceptance yet. Time will have to prove whether this will be the case in the future.

In the light of its comprehensive yet systematic and transparent nature, the SIM has the potential to become widely accepted. The fact that it yields end results in monetary terms, is applicable to all types of brands and intellectual property assets and in the course of all forecasting valuations is likely to be beneficial in this regard.

\subsubsection{Manageable Output}

As a management tool, the SIM needs to bring about manageable output. This means it must meet the requirements of future orientation and comparability of results.

\subsubsection{Future Orientation}

As elaborated above, one can recognise a good strategic valuation methodology in how successfully it is able to, amongst others, deal with future-related uncertainties and risks. ${ }^{600}$ For purposes of managerial decision making, which is per se future oriented, it is of central importance to apply a valuation tool which makes allowance for this.

The Systematic Integrated Methodology has been specifically developed as a business tool for forecasting valuations. As already specified, it is suitable for all future-related valuations and therefore meets the requirement of future orientation.

599 Cf. 4.1.2.2.2.

600 Cf. e.g. 1.2. 


\subsubsection{Comparability of Results}

Ideally, a valuation methodology shall provide for both absolute and relative, i.e. comparative, valuations. An absolute valuation result can be obtained by means of single application of any valuation method. However, contrary to such a single valuation, it is not until the valuation result is comparable to others that it is considerably more meaningful and useful. ${ }^{601}$

Such increased usefulness by means of comparability of valuation outcomes is achieved by the SIM mainly in two aspects: valuation object and time. ${ }^{602}$

Comparability of results as to the valuation object results from the fact that the SIM is applicable for all types of IP rights and brands.

In addition, the Systematic Integrated Methodology, if applied consecutively, enables value comparison or tracking over time. For example, a brand's value development can thus be made transparent. Although other valuation tools can also be applied repeatedly over time, the SIM can, in addition, be easily adapted to new or changed circumstances and is fully transparent. This provides for relatively better quality of the value outcomes and thus of the comparison itself.

\subsubsection{Findings}

The above details have shown that the SIM meets all mandatory requirements in a satisfactory way (save widespread acceptance which can only be proven in the future since the SIM is newly introduced here). However, this shall not belie the fact that it needs to be fine-tuned over time. Only then can its strengths fully develop and show.

602 In theory, a third aspect, the reason for valuation, also belongs in this category. As the SIM is applicable for all forecasting valuations, the outcome reached in the course of a licensing valuation could be compared to the value obtained for marketing controlling purposes. However, this is a theoretical rather than practical possibility as such comparison would probably not be demanded. In fact, it is a specific valuation motive, for example resource allocation, which triggers the need to compare valuation outcomes over time and/or from asset to asset. 


\subsection{Summary}

The Systematic Integrated Methodology, or SIM, is a business process oriented brand and intellectual property (e)valuation tool. As such, it is based on both fundamental issues pertaining to intangible asset and intellectual property valuation and on findings from the above analysis of current brand valuation methods. It uses the widely accepted income approach, coupled with DCF and decision tree analysis, as a starting point to compute a financial value spread which constitutes the outer limits of and a rough approximation to the asset's value. In the second step, the prismatic evaluation, operationalisation of all necessary contextual value determinants is carried out. Results from these two steps are then merged which yields a monetary end result consisting of an expected value, backed by systematically and holistically collected contextual information about the valued asset.

The SIM thereby serves to obtain a comprehensive financial value outcome which enables full tradeability and manageability of the respective brand or IP right as an asset. As far as it can be stated today, it meets all mandatory requirements a proper intellectual property valuation methodology is supposed to meet.

Thus, an uncertain future can be reflected flexibly and systematically on a comprehensively understood present. ${ }^{603}$

603 Instead of reflecting an uncertain future on a fragmentarily understood present, as most currently applied brand valuation techniques do, cf. 3.3.1. 



\section{Chapter 5}

\section{The Legal Dimension}

\subsection{Introduction}

In most industry branches in developed economies, companies have become increasingly brand-focussed. ${ }^{604}$ It is therefore not surprising that trade mark protection has become an indispensable element of brand strategies. Correspondingly, the number of trade mark registrations is soaring in order to safeguard the legal side of brand-related freedom to operate. For instance, WIPO received the record number of 39,975 international trade mark filings in 2007. ${ }^{605}$ The number of trade marks registered with the German Patent and Trade Mark Office (DPMA) also shows a stable upward trend, ${ }^{606}$ which in recent years has been mainly ascribed to the services sector. ${ }^{607}$

Generally speaking, trade mark law gives the proprietor an exclusive affirmative right to use the respective mark and a negative right to exclude others from using the same or - in case of likelihood of confusion - a similar sign. Prerequisite for both cases is that a third person uses the conflicting mark in trade or commerce. Once it has been effectively laid down that the title holder's trade mark rights have been violated, he or she is in the position to claim remedies such as damages, cease and desist, destruction of goods illegitimately marked with the infringing sign(s) and - as an auxiliary right in

604 Cf. 2.2.1.

605 Cf. World Intellectual Property Organization (WIPO), Record Number of International Trademark Filings in 2007.

606 Cf. 2.2.1. On how to obtain a trade mark registration on the national (German), European and international levels see below at 5.6.

607 Göbel, markenartikel 11/2008, 93, 93. 
order to realise the above claims - disclosure of all necessary information. ${ }^{608}$

The manner in which legal aspects are dealt with in the course of brand valuation methods and publications is non-uniform. Some make allowance for legal aspects. However, the main focus of current publications lies on the financial valuation of brands - in most cases based on the income approach - with some marketing issues taken into account. ${ }^{609}$ Legal aspects play, if at all, a secondary role. Some brand valuation methods deal with legal aspects under the heading "brand protection status" 610 or "competitor analysis" 611 and deal with issues such as whether and where there exists a registered trade mark. ${ }^{612}$

This chapter uses this situation as an opportunity to comprehensively analyse the link between trade mark law and brand value, supposing there exists one. It will be assessed which legal issues can have an impact on brand value, why this is the case and, if possible, to what degree and in which situations this impact can be felt. Hereby, European law will be mainly dealt with, with some references made to German law.

As set forth in chapter two, ${ }^{613}$ it is not until intellectual achievements are protected as intellectual property that they become scarce and therefore potentially valuable. Brands and other products of the mind are per se free: a certain sign or a specific idea which is neither kept secret nor protected

608 Cf. e.g. Art. 9 CTMR; $\S \S 14,16-19$ MarkenG. In order to facilitate smooth reading of this document, only the respective CTMR articles will be cited, unless the provisions of CTMR and CTMD differ contentwise. As far as provisions of CTMR and CTMD correspond, their interpretation by CFI and ECJ, even if it originally deals with the CTMR, is also valid as regards the CTMD and thereby for the harmonised national laws.

609 For example, two important recent German publications scrutinising current brand valuation methods do not mention legal aspects at all but are completely written from a financial perspective: Frahm, Markenbewertung. Ein empirischer Vergleich von Bewertungsmethoden und Markenwertindikatoren (Frankfurt am Main 2004) and Bentele/Buchele/Hoepfner/Liebert, Markenwert und Markenwertermittlung (Wiesbaden 2003).

610 Spannagl/Biesalski, Brand Rating-Modell, p. 98 et seq.

611 Stucky, Interbrand-Modell, p. 117 et seq.

612 This focus on financial issues is on the one hand understandable, because a financial valuation outcome is desired (therefore a financial method is needed as opposed to a merely psychographic one) (for more information regarding differences between financial and psychographic methods cf. 3.1.2) and marketing is the discipline to wich brands are central both in theory and in practice (hence, marketing aspects must constitute an indispensable part of any brand valuation method). On the other hand, as explained above, there are more aspects than financial and marketing-related ones which affect brand value (cf. 1.3, 2.1.1.4, 2.1.3 and 3.3.2.). These include legal ones.

613 At 2.1.1.3.7. 
by law can be used simultaneously by an infinite number of persons, which means that it is not scarce. As a consequence, it will not be exchanged for money or other consideration and therefore attain no market value. Apart from secrecy (which is not an option for trade marks due to their nature as communicative signs but for other IP such as patents), it is not until the law steps in and awards protection to intellectual achievements - thereby turning them into intellectual property - that they are allocated to one or a few specific proprietor(s) and thus become scarce. This normatively imposed scarcity prevents everyone but the proprietor(s) from using the IP at their free discretion. The respective IP can thus be exploited or otherwise utilised, which means it is able to develop a value. This means that the legal framework protecting intellectual achievements as subjective rights constitutes the basis of all brand and IP value. Hence, legal aspects cannot be ignored but are important factors of trade mark value and thereby - since trade marks generally constitute important parts of brands ${ }^{614}$ - also of brand value. This makes a detailed analysis of a multitude of partly complex legal issues essential for an authoritative brand valuation.

In contrast to patent and other IP valuation, there are circumstances unique to brands the valuator needs to be aware of: the fact that only the trade mark(s) and not the respective brand is protected by trade mark law and the interplay between trade marks and brands.

The fact that a trade mark is duly registered and therefore contains a potential to be exploited as an asset (licencing, franchising etc.) and used as part of a brand for marketing purposes constitutes a value per se, even though not a high one. In juvenile status, a brand does not consist of much more than the trade mark itself, because the intrinsic elements of the brand such as image and identity ${ }^{615}$ have not yet had the time to develop on the market and be recognised by the target audiences. This shows that the legal protection of a registered trade mark is especially important in the initial phase of the life of a brand, ${ }^{616}$ i.e. in a phase in which the intrinsic elements of a brand other than the trade mark are still juvenile and not very strong - neither internally nor on the market.

\section{Cf. 2.1.2.}

615 For an explanation of these terms, see above at 2.1.2.2.1.

616 Solely registered trade marks are mentioned in this context because, in early life of a brand, the respective trade mark will not be used or well-known enough in order to be protected outside the scope of a formal registration. 
Later in the life of a brand - once it has attained a certain degree of market penetration and awareness - failing trade mark protection alone may not necessarily endanger the life of the corresponding brand. Even if the trade mark protection as such ceased to exist, the device, i.e. the signage, and all other elements of a brand would still be in place. ${ }^{617}$ These elements would have developed a certain degree of strength and recognition over time. Therefore, it is not an automatism that failing or lost legal (trade mark) protection necessarily means that the respective brand ceases to exist, becomes useless and valueless. Depending on the circumstances of each case, it would be possible that the proprietor was still in a position to successfully market his goods or services. Even though competitors would be free to use the same or similar sign(s) for the same or similar goods or services according to trade mark law, the proprietor may already have achieved a degree of market share, market penetration, marketing channels and product quality which would be factually difficult to attack. Furthermore, he may receive protection by means of other legal regimes such as competition law. ${ }^{618}$ Hence, whether competitors succeeded with their endeavours would be a question of strength of the former trade mark proprietor's branding, marketing and other activities coupled with legal regimes other than trade mark law.

In addition, the device may have become so strong that, even though the mark as such is or has become descriptive/generic or non-distinctive, it does in fact attain legal protection, for instance based on acquired distinctiveness through use or as a well-known mark.

Apart from the central and basic function of value creation through legal scarcity, there are a number of specific aspects of trade mark protection, such as the degree of distinctiveness of the sign, which can have an influence on brand value. These issues will now be discussed in detail.

Although this discussion is carried out in light of practical application in the course of the SIM, all issues which could be important will be introduced in a manner detailed enough to understand their possible relation (or non-

617 This is an expression of the abovementioned fundamental difference between patents (and other IP) and brands. If legal patent protection fails, the whole patent ceases to exist. It completely loses its value. On the other hand, in case of failing trade mark protection, the rest of the brand is still in place. This shows how important it is to be exactly aware of the nature of the valuation object.

618 Competition law regimes are always important to be considered in intellectual property cases. However, dealing with such aspects in this work would go beyond its scope. 
relatedness respectively) to brand value. Hence, the objectives of focussing on the examination of possible implications of certain trade mark law issues on brand value, thereby keeping the introduction of the relevant laws as short as possible, and of providing sufficient background knowledge on these laws are balanced. ${ }^{619}$

For purposes of clarity, the order in which legal issues will be discussed hereafter roughly follows the system in which trade mark law is laid down in Germany and on the European level. It does not indicate a graduation of importance of the respective points.

The following aspects will be, as a default, evaluated with respect to registered trade marks, since this work's focus lies on harmonised European trade mark law, which in large part governs registered trade marks (for instance, trade marks acquired through use ${ }^{620}$ are, on the European level, merely taken into account in terms of the relationship between them and registered trade marks $\left.{ }^{621}\right) .{ }^{622}$ Some issues in the legal dimension would have to be added or ommitted in case a well-known ${ }^{623}$ mark, a trade mark acquired through use $^{624}$, a mark with a reputation ${ }^{625}$ or a trade mark application ${ }^{626}$ has to be assessed.

619 In consequence, the following analysis does and cannot serve the purpose of discussing trade mark law in every detail. There are numerous publications providing an adequately particularised overview of German and European trade mark law should the reader wish more detailed information. Cf. e.g. Bender, Europäisches Markenrecht. Einführung in das Gemeinschaftsmarkensystem; Berlit, Markenrecht; Bingener, Markenrecht; Davies, Sweet \& Maxwell's European trade mark litigation handbook; Fezer, Markengesetz (commentary); Gold, The Community Trade Mark Handbook; Hildebrandt, Marken und andere Kennzeichen; Ingerl/Rohnke, Markengesetz (commentary); Lange, Marken- und Kennzeichenrecht; Nordemann, Wettbewerbsrecht Markenrecht.

$620 \S 4$ no. 2 MarkenG (Verkehrsgeltung).

621 Fourth Recital CTMD.

622 Furthermore, registered trade marks constitute the lion's share of all trade marks, arg. e von Bomhard, Lovells Intellectual Property Newsletter January 2008, p. 12, stating that most owners of well-known marks have a registration anyway.

623 Art. $^{\text {bis }}$ Paris Convention. Cf. below at 5.7.2 and 5.12.3.

624 Infra at 5.7.3.

625 Infra at 5.12.2.

626 A trade mark application per se is capable of developing a value, since the applicant has a right to be granted a registration if all requirements are met. As a consequence, more of the below issues would have to be assessed by way of prognosis than with regard to a registered trade mark. In addition to that, the evaluation system would need to be customised for trade marks which have not accrued legal protection through registration but through use or notoriety, e.g. by excluding all points relating to trade mark registration. 
and Graphical Representation

\subsubsection{Introductory Remarks}

A sign is protectable as a trade mark if it is distinctive (in both an abstract and a concrete sense), non-descriptive and graphically representable. ${ }^{627}$

The issues of distinctiveness and non-descriptiveness are central points in the realm of trade mark protection. They allude to the core function and raison d' être of every mark: the origin function, i.e. the ability to distinguish goods or services of one source from those of a different one, thereby signalling the specific origin of the marked products or services.

Graphical representation has been introduced in order to provide legal certainty, especially for competitors and others, with regard to what exactly is covered by the registered trade mark in question. ${ }^{628}$ In contrast to distinctiveness and non-descriptiveness, it is a formal criterion.

All trade mark offices examine absolute grounds for refusal of trade mark protection, including the qualitative scope of protection, in the course of the registration procedure. This examination, however, does not constitute a guarantee that these points will never again be questioned once the trade mark is registered. It merely offers a rebuttable presumption of validity of the mark with respect to the examined grounds. For this reason, the proprietor enjoys some degree of but not full legal certainty with regard to the nonexistence of absolute grounds for refusal of trade mark protection.

Each of these absolute grounds listed in Art. 7(1) CTMR is independent and must therefore be examined separately. ${ }^{629}$ In the course of such examination, they are to be interpreted in light of the respective underlying general interest. $^{630}$ In case of Art. 7(1)(b)-(e) CTMR (wich include non-distinctiveness

627 Strictly speaking, the law distinguishes between abstract distinctiveness as part of eligibility for trade mark protection and lacking concrete distinctiveness as an absolute ground of refusal of protection. However, from a valuation point of view, this difference does not significantly influence value or the valuation process. Rather, it seems expedient to combine these issues under the heading of qualitative scope of protection. Hereby, two thematically related issues are dealt with under the same heading.

628 Ströbele/Hacker, Markengesetz, § 3 no. 12.

629 ECJ, above fn. 125 - DAS PRINZIP DER BEQUEMLICHKEIT, para. 39.

630 ECJ, judgment of 16 September 2004, Case C-329/02 P, [2004] ECR I-8317, SAT.1 
and descriptiveness), this public interest is to keep the comprised signs free for all to use. ${ }^{631}$ In order to prevent the proprietor from obtaining an undue competitive advantage, thus balancing public and private interests, such signs shall only be allocated an exclusive right in case the relevant public has in fact come to perceive them as designations of a commercial origin, Art. 7(3) CTMR. ${ }^{632}$ The law thus tries to define those instances in which the proprietor's efforts are worth being rewarded. ${ }^{633}$

\subsubsection{Abstract Distinctiveness}

\subsubsection{The Law in General}

The criterion of distinctiveness can be found twofold, both in German and European law: both as an issue of general ability of a sign to constitute a trade mark (Art. 4 CTMR, $\S 3(1)$ MarkenG) and as an absolute ground of refusal of registration upon its absence (Art. 7(1)(b) CTMR, § 8(2) no. 1 MarkenG).

This dichotomy is being interpreted to the effect that distinctiveness in the course of trade markability is an abstract one, meaning that any sign is capable of constituting a trade mark provided it is theoretically able to distinguish any goods or services of one undertaking from those of another. ${ }^{634} \mathrm{Al}-$ though this constitutes a mandatory prerequisite for trade mark protection,

SatellitenFernsehen GmbH v. Office for Harmonisation in the Internal Market (Trade Marks and Designs) (OHIM) - SAT.2, para. 25.

631 This has to be seen in the light of fact that European trade mark law is concerned with ensuring free movement of goods and services within the internal market, cf. Recital one CTMD, Recital one CTMR.

632 CFI, judgment of 2 July 2002, Case T-323/00, [2002] ECR II-2839, SAT.1 SatellitenFernsehen GmbH v. Office for Harmonisation in the Internal Market (Trade Marks and Designs) (OHIM) - SAT.2, para. 36 .

633 Hence, the concept of reward cannot only be found in patent law. As the CFI observed in August Storck, judgment of 10 November 2004, Case T-402/02, [2004] ECR II3849, August Storck KG v. Office for Harmonisation in the Internal Market (Trade Marks and Designs) (OHIM), para. 76, a case dealing with an application for trade mark protection of a sweets wrapper, "...the fact that the sign which constitutes the mark in question is actually perceived by the relevant section of the public as an indication of the commercial origin of a product or service is the result of the economic effort made by the trade mark applicant. That fact justifies putting aside the publicinterest considerations underlying Article 7(1)(b) to (d), which require that the marks referred to in those provisions may be freely used by all in order to avoid conceding an unjustified competitive advantage to a single trader ...".

634 Cf. e.g. Fezer, Markenrecht, $\S 3$ no. 203 et seq.; Ingerl/Rohnke, Markengesetz, $\S 3$ no. $9, \S 8$ at no. 2 et seq. 
the threshold for reaching an affirmative view on abstract distinctiveness is extremely low. Any communicative, or perceivable, sign can be distinctive in abstracto, as it is possible that there exists a recipient who attaches a meaning to it. Hence, the requirement of abstract distinctiveness can be practically neglected. ${ }^{635}$ It is highly unlikely that a valuator or a legal practitioner will have to deal with a sign which is not abstractly distinctive.

\subsubsection{Value Implications}

As this point is therefore not suitable for distinguishing trade marks according to their legal strength, it has no bearing on the value potential of the respective sign.

Hence, it is unimportant in connection with trade mark and brand value. For this reason, it is not advisable to list this aspect as an issue in the legal dimension of the SIM.

\subsubsection{Concrete Distinctiveness}

\subsubsection{The Law in General}

It follows from the abovementioned that affirmed abstract distinctiveness cannot act as an indicator in favour of or against approval of concrete distinctiveness. Furthermore, whereas absent abstract distinctiveness would inevitably result in negation of trade mark protection, a viable sign lacking concrete distinctiveness can nevertheless be registered if it has acquired distinctiveness through use on the filing date, persisting at the time of decision on registrability, with respect to the goods or services claimed. ${ }^{636}$

635 Marx, Deutsches, europäisches und internationales Markenrecht, at no. 139.

636 Art. 7(3) CTMR; § 8(3) MarkenG; ECJ, judgment of 6 May 2003, Case C-104/01, [2003] ECR I-3793, Libertel Groep BV v. Benelux-Merkenbureau, - Libertel, para. 67. Such acquired distinctiveness exists when it is recognised by a sufficiently large part of the relevant public as belonging to one certain trader. It needs to be proven with respect to every country the trade mark is registered for or where an objection was raised respectively. In its landmark Windsurfing Chiemsee ruling (judgment of 4 May 1999, Joined Cases C-108/97 and C-109/97, [1999] ECR I-2779, Windsurfing Chiemsee Produktions- und Vertriebs GmbH (WSC) v. Boots- und Segelzubehör Walter Huber and Franz Attenberger - WINDSURFING CHIEMSEE), the ECJ set forth the key parameters concerning the assessment of acquired distinctiveness of a mark. These requirements have since been approved of by both the ECJ itself (cf. e.g. above fn. 125 - Philips/Remington, para.s 60-61) and OHIM (Office for Harmonization in 
Neither codified European nor German law can and does stipulate what distinctiveness in this sense ${ }^{637}$ exactly means, as distinctiveness needs to be examined separately in each case for the specific goods and/or services for which protection is sought. ${ }^{638}$ Courts have interpreted concrete distinctiveness to require the ability of the respective mark to distinguish goods or services from one undertaking from those of another in a concrete sense, thereby enabling the allocation of the goods or services to a specific corporate source. ${ }^{639}$

the Internal Market (Trade Marks and Designs) (OHIM), Guidelines Concerning Proceedings before the Office for Harmonization in the Internal Market (Trade Marks and Designs) - Part B, Examination, at 8.9.). As a result, OHIM has persistently required the following conditions to be satisfied: (1) that a trade mark must be used in the European Community (EC) as a whole or, at least, in a substantial part thereof, or, at least, in those parts of the EC where the distinctive character is lacking, in such a way that (2) a sufficiently large part of the relevant class of persons recognise the sign as a distinctive trade mark at the time when the application is filed (Gold, The Community Trade Mark Handbook, para. 8-016). If these requirements are met, the mark in question has "gained a new significance and its connotation, no longer purely descriptive, justifies its registration as a trade mark" (ECJ in Windsurfing Chiemsee at no. 47). The Windsurfing Chiemsee decision, even though it was handed down regarding a geographical name, is valid for trade mark law in general and so central that it should be a starting point for every assessment of acquired distinctiveness. However, so far there seems to be no clear-cut OHIM case law establishing when the threshold for proving acquired distinctiveness has been met. It seems that originally generous decision making has now given way to a more restrictive practice (cf. e.g. for olfactory marks OHIM, decision of 11 February 1999, Case R 156/1999-2 - THE SMELL OF FRESH CUT GRASS on the one hand and OHIM, decision of 5 December 2001, Case R 711/1999-3 - DER DUFT VON HIMBEEREN on the other). The development of case law by the CFI and ECJ in the upcoming years will be of central importance in this area and thus needs to be closely monitored.

637 The notion of distinctiveness as regulated by Art. 7(1)(b) CTMR is - in the case of its absence - a so-called absolute ground of refusal of trade mark protection of the respective sign. As all other such absolute grounds, (these grounds are listed exhaustively in Art. 3 CTMD and Art. 7 CTMR respectively) Art. 7(1)(b) CTMR is a public interest ground for denial of trade mark protection (Ingerl/Rohnke, Markengesetz, § 8 no. 1) and is examined ex officio. This provision relates exclusively to signs pending for trade mark registration, which means e contrario that it has no effect on signs accruing protection as a trade mark through use, $\S 4$ no. 2 MarkenG (in German: Benutzungsmarke mit Verkehrsgeltung), or notoriety, $\S 4$ no. 3 MarkenG, Art. $6^{\text {bis }}$ Paris Convention.

638 Other than in German law (this can be deduced from the wording of $\S 8(2)$ no. 1 MarkenG, which mentions the concrete goods or services directly. Additionally, the German Federal Supreme Court (BGH) recognises this in its settled case law, cf. e.g. IIC 1998, 337 - PROTECH), this does not result from the exact wording of the above European provisions, but can be deduced from the systematic context in which these provisions stand and is undisputed today. The related provision of Art. 7(3) CTMR for example, which deals with acquired distinctiveness, speaks of distinctiveness "in relation to the goods or services for which registration is requested". See also Ingerl, Die Gemeinschaftsmarke, p. 57.

639 Settled case law of the European Court of Justice (ECJ) and national courts, cf. e.g. 
This definition shows that it needs to be established in each case whether the particular sign is seen by the relevant public as reference to the commercial origin of the respective goods or services, i.e. whether it is distinctive with the ability to exercise the origin function. ${ }^{640}$ In other words: The trade mark needs to make the goods or services primarily distinguishable by origin, not by their quality or designation. ${ }^{641}$ Thereby, all relevant facts of the case need to be taken into account, relating to the sign itself, the relevant target audience and the goods and/or services in question. ${ }^{642}$

In terms of the relevant part of the public, i.e. the portion of the public which is addressed by the respective sign, ${ }^{643}$ the mark must be recognised as distinctive by the majority. Hereby, the assumed perception of this audience in the form of the "average consumer, who is reasonably well informed and

ECJ, above fn. 125 - Canon, para. 27; ECJ, above fn. 125 - Philips, para. 30; ECJ, judgment of 29 April 2004, Joined Cases C-456/01 P and C-457/01 P, [2004] ECR I5089, Henkel KGaA v. Office for Harmonisation in the Internal Market (Trade Marks and Designs) (OHIM) - Henkel, para. 48; BGH IIC 2001, 584 - St. Pauli Girl. This shows that the origin function of trade marks (as explained above at 2.1.2.1.3) is essential for the assessment of distinctiveness.

640 ECJ in Canon (supra fn. 125) at no. 27; PRINZIP DER BEQUEMLICHKEIT (above, fn. 125 , para. 42 .

641 This does not mean, however, that the person of the applicant is primarily important for the assessment of this issue, for example with regard to his or her identity or position in the market (Ströbele/Hacker, Markengesetz, $\S 8$ no. 50). The respective sign must be able to individualise a certain product or service by name and at the same time refer to a certain commercial source, which itself does not have to be known (Marx, Deutsches, europäisches und internationales Markenrecht, at no. 412).

642 ECJ, above at fn. 636, Libertel, para. 76; judgment of 12 February 2004, Case C369/99, [2004] ECR I-1619, Koninklijke KPN Nederland NV v. Benelux-Merkenbureau - Postkantoor, para. 37; judgment of 7 October 2004, Case C-136/02 P, [2004] ECR I-9165, Mag Instrument Inc. v. Office for Harmonisation in the Internal Market (Trade Marks and Designs) - Maglite, para. 48.

643 Ingerl, Die Gemeinschaftsmarke, p. 58. In case of litigation, this may be assessed by means of market research. The examining office, however, has no obligation to consult market or demoscopic research (BGH, judgment of 13 May 1991, Case I ZB 8/91 - MICRO CHANNEL; Ingerl/Rohnke, $§ 8$ no. 19). In the course of assessment of concrete distinctiveness as part of an evaluation of the legal dimension of the SIM, it would also be too costly and time-consuming to conduct market research. This would however not be necessary since the approach to IP evaluation as exercised through the SIM relies on thorough experts' appraisals rather than on costly collection of raw data. In addition, it is in most cases relatively straightforward to judge who the relevant part of the public consists of. For example, in the case of a trade mark for fast moving consumer goods such as washing detergent, it will have to be proven that the general consuming public as a whole - or at least a substantial part of it - recognises the respective sign as a trade mark. On the other hand, if for example a mark being in connection with customised software for law firms is under scrutiny, the perceived view of attorneys and paralegals would be key. 
reasonably observant and circumspect" 644645 applies as a basic rule in case the respective goods or services are intended for all consumers.

As mentioned above, concrete distinctiveness can only be assessed in light of the specific goods or services for which the trade mark shall be registered. A sign may merely have lexical meaning for a certain group of goods but be seen as a reference to a specific commercial origin with respect to another. Hence, the catalogue of goods and services needs to be diligently put together for each mark to be registered. ${ }^{646}$

The question of concrete distinctiveness is one of law and not of fact, which the offices and courts have to assess by way of own appraisal. ${ }^{647}$ In the course of a trade mark application procedure, the assessment of concrete distinctiveness can therefore only be carried out by means of prognosis.

Any degree or type of distinctiveness is sufficient in order to reach an affirmative view in this regard. ${ }^{648} \mathrm{~A}$ trade mark which shows a degree of distinctiveness near the bottom end of what is protectable will, however, have a weaker scope of protection than a sign which is highly distinctive. This is not a question of meeting the requirement of concrete distinctiveness but rather of strength of the trade mark and barring effect vis-à-vis other marks. The degree of distinctiveness becomes particularly important for the assessment of likelihood of confusion: the higher the degree of distinctiveness of the older mark, the greater the likelihood of confusion. ${ }^{649}$ For the discussion of concrete

644 ECJ, above fn. 630 - SAT.2, para. 24; judgment of 30 June 2005, Case C-286/04 P, [2005] ECR I-5797, Eurocermex SA v. Office for Harmonisation in the Internal Market (Trade Marks and Designs) (OHIM) - Eurocermex, para. 31. The ECJ had originally developed this general consumer model for the assessment of likelihood of deception in competition law, cf. the landmark Gut Springheide decision (judgment of 16 July 1998, Case C-210/96, [1998] ECR I-4657, para. 31) and ECJ, decision of 13 January 2000, Case C-220/98, [2000] ECR I-117 - Estee Lauder/Lancaster, para. 27. However, the model is valid for competition law in a wider sense, which includes trade mark law, and therefore has been adopted for trade marks by the ECJ in Lloyd Schuhfabrik Meyer (judgment of 22 June 1999, Case C-342/97, [1999] ECR I-3819, Lloyd Schuhfabrik Meyer \& Co. GmbH v Klijsen Handel BV).

645 This shall not preclude that - as an exception to the rule - special knowledge needs to play a role in certain cases, cf. ECJ, above fn. 642 - Maglite, para. 49.

646 Marx, Deutsches, europäisches und internationales Markenrecht, no.s 421, 422.

647 This means they are not bound by expert advice or evidence produced by the parties, but may accept these at own discretion, cf. ECJ, above fn. 642 - Maglite, para. 67.

648 Cf. Art. 7 (1)(b) CTMR - "devoid of any distinctive character"; CFI, judgment of 27 February 2002, Case T-34/00, [2002] ECR II-683, f Logistik GmbH v. Office for Harmonisation in the Internal Market (Trade Marks and Designs) (OHIM) - EUROCOOL, para. 39; BGH IIC 2002, 883 - RATIONAL SOFTWARE CORPORATION. 649 CFI, judgment of 19 October 2006, Joined Cases T-350/04 to T-352/04, [2006] ECR II- 
distinctiveness here, it is sufficient to know that any degree of distinctiveness of the sign meets the requirements, be it suggestive, arbitrary or fanciful. ${ }^{650}$

Even though the criteria and standard test for distinctiveness are the same with respect to all categories of signs ${ }^{651}$ it may de facto be more difficult for certain signs to reach affirmed distinctiveness or acquired distinctiveness respectively, as not every category of signs is being perceived by the relevant public as possible references to a commercial origin. The 'classical' word and figurative marks as well as combinations thereof are not problematic in this regard whereas non-traditional signs such as three-dimensional marks and colours per se tend to bring about more factual issues. Therefore, these categories of signs shall be briefly introduced in the following. ${ }^{652}$

\subsubsection{Three-dimensional Marks}

The fact that three-dimensional signs are generally able to be protected as trade marks is expressed by Art. 4 CTMR ("A Community trade mark may consist of ...the shape of goods or of their packaging ..."). This provision

4255, Bitburger Brauerei Th. Simon GmbH v. Office for Harmonisation in the Internal Market (Trade Marks and Designs) (OHIM) - Bud.

650 This terminology originates from US case law but is generally useful for a systematisation of in-depth assessment of the degree of distinctiveness of a sign.

651 As no type of sign is prima facie excluded from possible trade mark protection, this is logical. It is also constantly affirmed by the ECJ in its case law, cf. e.g. above fn. 639 - Henkel; above fn. 125 - DAS PRINZIP DER BEQUEMLICHKEIT.

652 With respect to combination marks, it is important to note that, since the relevant part of the public, whose opinion is decisive for the question of concrete distinctiveness, perceives the sign as a whole, key object of scrutiny can only be the sign as a whole as well. This means that composite marks may generally not be divided up into their respective parts (BGH IIC 2002, 883 - RATIONAL SOFTWARE CORPORATION (regarding word marks); BGH IIC 1996, $734-U-K E Y$ (for combination marks); BPatG, judgment of 4 July 2001, Case $29 \mathrm{~W}$ (pat) 11/00 - BiC-Kugelschreiber (regarding combinations of words and three-dimensional marks). Distinctiveness may be examined separately for each part of the sign, but must, at any rate, depend on assessment of the sign in its entirety. The reason for this is that each part of the sign per se not being distinctive does not mean that the sign as a whole lacks distinctiveness as well, cf. CFI, judgment of 12 December 2007, Case T-117/06, [2007] ECR II-174, DeTeMedien Deutsche Telekom Medien GmbH v. Office for Harmonisation in the Internal Market (Trade Marks and Designs) (OHIM) - suchen.de, para. 31. This does not preclude, however, that an interplay between different parts of the sign may decide for or against registrability of the sign as a whole. Take for example a situation in which the trade mark pending contains at least one non-marginal element which is itself protectable (whereas the rest by itself would not be): in this case, the sign as a whole will be registrable, unless it becomes unprotectable specifically due to the combination of its parts, which would be an extremely rare case (Ingerl/Rohnke, $\S 8$ no. 55). 
refers to the so-called 'product dependent' three-dimensional signs. In addition, there are product independent three-dimensional trade marks, such as Daimler's star-shaped bonnet ornament. ${ }^{653}$ Contrary to the latter, the former bring about peculiarities with respect to distinctiveness due to the fact that they consist of the shape of the respective product or of its packaging. Therefore, the relevant public may not perceive them as references to a commercial origin but rather as part of the marked product itself.

Hence, whereas the law stipulates the requirement of having to be "capable of distinguishing the goods or services of one undertaking from those of other undertakings" (Art. 4 CTMR) for all categories of signs, this may be difficult to establish for a product dependent shape due to the fact that it is not being perceived as a reference to a certain commercial source. ${ }^{654}$ However, concrete distinctiveness has been affirmed in cases in which the respective shape contains fancy, prominent elements which allow the respective target audiences to memorise and recognise the form. ${ }^{655}$

Not being questions of distinctiveness yet connected to the issue of trade mark protection of product-related shapes are the further absolute grounds for refusal of trade mark protection listed in Art. 7(1)(e) CTMR (they are important points which are usually scrutinised in cases in which distinctiveness of a shape is problematic and shall therefore be mentioned at this point as well). This provision states that the form of three-dimensional signs may not merely be contingent on technical requirements, the nature of the respective goods or the shape giving substantial value to the goods. ${ }^{656}$ This does not mean, however, that only fanciful forms, such as Rolls-Royce's hood ornament 'Emily', are capable of constituting a three-dimensional trade mark. With respect to the exclusion of mere contingency on technical requirements, for example, product dependent shapes can be protected as trade marks,

653 Marx, Deutsches, europäisches und internationales Markenrecht, no. 190.

654 However, as the existence of a number of product dependent three-dimensional marks shows, this is not impossible. For example, the bottle of the 'OdOL' mouthwater is protected as a three-dimensional mark (file number 004361069, registered with OHIM in the name of SmithKline Beecham Consumer Healthcare GmbH on May 17, 2006 for Nice classes three, five, 10 and 21.).

655 OHIM, decision of 4 August 1999, Case R 139/1999-1, - Granini bottle.

656 Art. 7(1)(e) CTMR is seen as protecting a 'need to keep free', which would be undermined if the outer appearance of a product, for the protection of which patent, design and utility model protection (which are all temporally limited) can be resorted to, would be protected by trade mark law (which can be done over an unlimited time span). Cf. Kur, MarkenR 2000, 1, 3; Ingerl/Rohnke, Markengesetz, § 3 no. 41. 
even if they are at the same time to some extent functional. ${ }^{657}$ The decisive question is whether the form in question provides for non-technical elements which reach above the technically contingent basic shape. ${ }^{658}$

\subsubsection{Colours and Colour Combinations}

Like shapes, mere colour combinations or compositions of abstract colours, without contours, are nowadays widely accepted as being both eligible as a trade mark and of being capable to be inherently distinctive. ${ }^{659}$ This was much disputed yet clarified by the ECJ in Liberte ${ }^{660}$ and affirmed in Heidelberger Bauchemie. ${ }^{661}$

Unlike figurative or combination marks (which may be designed in colour), abstract, shapeless colours per se can be deployed in an unlimited variety of contours. In addition, colours can not be memorised as easily as can words and figures. Most importantly, they are widely utilised for aesthetic reasons, which means that the relevant part of the public is not used to perceiving them as allusions to a commercial origin but rather, as a general rule, as characteristics of the respective product or its packaging. ${ }^{62}$ These aspects cause distinctiveness of abstract colours and colour combinations, without any prior use, to be affirmed merely in exceptional cases, ${ }^{663}$ mainly in which the number of goods or services for which the trade mark is sought to be registered is very limited and the relevant market is very specific, ${ }^{664}$ for instance in the telecommunications sector. In addition, regard must be had to the 'need to keep free', i.e. the "general interest in not unduly restricting the

657 Ingerl/Rohnke, Markengesetz, $\S 3$ no. 32.

658 ECJ, above fn. 125 - Philips/Remington; OHIM, above fn. 655 - Granini bottle; BGH IIC 2002, 886 - Stabtaschenlampen.

659 Unlike shapes, they are not listed in Art. 4 CTMR. However, this provision is not exhaustive.

660 Cf. fn. 636.

661 Judgment of 24 June 2004, Case C-49/02, [2004] ECR I-6129, Heidelberger Bauchemie $\mathrm{GmbH}$. Note that the ECJ paved the way for recognising distinctiveness of abstract colours by accepting graphical representability of such marks. For example, a single abstract colour can be registered if the application contains a colour sample, an objective specification of the colour (e.g. by means of the Pantone scale) and a verbal description.

662 ECJ, cf. fn. 636 - Libertel, para. 65; Marx, Deutsches, europäisches und internationales Markenrecht, at no. 179.

663 This does not preclude the possibility of such colours to develop distinctiveness through use, cf. ECJ, above fn. 636 - Libertel, para. 67.

664 ECJ, supra fn. 636 - Libertel, para. 66. 
availability of colours for the other traders who offer for sale goods or services of the same type" as those with respect to which the mark is claimed. ${ }^{665}$

Correspondingly, inherent distinctiveness of abstract colours and colour combinations per se was denied in most of the cases decided recently. ${ }^{666}$ Registrability is, in most cases, only possible in case the sign has acquired distinctiveness through use. ${ }^{667}$

\subsubsection{Vowel-free Marks}

A new development based on traditional word marks, but with a potentially significant impact on the protectability of the signs is worth mentioning: the trend of omitting vowels in words, slogans etc. This trend, originating to a large extent in the fact that many people were and are leaving out vowels to write SMS more quickly, is now widely used in branding and advertising. Motorola was one of the first multi-national companies availing itself of this possibility, naming one of its mobile phones 'SLVR' (meaning 'sliver').

The important implication of this trend is that it can actually help businesses find brand names which are satisfyingly distinctive - a task which becomes increasingly difficult nowadays since numbers of trade mark registrations and brands soar. In the case of Flickr, the popular online picture sharing service, it even enabled the business to go online at all: the service was planned to be called 'Flicker', but that domain name had already been registered. ${ }^{668}$

\subsubsection{Value Implications}

Concrete distinctiveness, both inherent and acquired, is a central characteristic to each trade mark, accounting for its ability to perform its main function - to act as a source identifier. Thereby, together with all other elements of a brand, it provides for risk reduction on both proprietors' and consumers'

665 ECJ, above fn. 636 - Libertel, para.s 52-56; fn. 661 - Heidelberger Bauchemie, para. 41.

666 Cf. e.g. BPatG, judgment of 26 January 2005, Case 32 W (pat) 353/03 - Yellow Pantone 123 U; Ströbele/Hacker, § 8 at no.s 157 et seq.

667 ECJ, supra fn. 636 - Libertel, para. 67. For instance, the BPatG denied inherent distinctiveness of the colour 'BROWN Pantone Nr. 4625U' for a parcel delivery service yet accepted acquired distinctiveness on the basis of a demoscopic report showing a degree of attribution of the sign to the proprietor by $71.9 \%$ of the relevant public, cf. BPatG, judgment of 14 February 2007, Case $26 \mathrm{~W}$ (pat) 15/00.

668 Abelson, Merchants X out A, E, I, O and U. 
sides $^{669}$ and enables commercial exchange to take place, which secures revenue streams. Distinctiveness of a trade mark is therefore not merely an important point of scrutiny in the legal dimension because it is part of the system turning a theoretically free sign into legally secured property, but also due to the fact that it is strongly linked to the value building potential of the respective brand.

As this link between distinctiveness of the sign and value of the corresponding brand is purely qualitative and dependent on the situation, it cannot exist as a fixed statistical or mathematical relation. Rather, statements in this regard must be made on a case by case basis.

Two general rules can be laid down at this point. Firstly, a lack of abstract and concrete (inherent and acquired) distinctiveness means failing trade mark protection, which entails considerable negative consequences for the marketability of the respective product or service and therefore for the value of the brand, particularly at early stages. ${ }^{670}$ Hence, missing distinctiveness is a clear value detractor.

Secondly, in case distinctiveness is affirmed, it can be located on a qualitative scale anywhere between 'barely distinctive' and 'highly distinctive'. It is not merely a 'yes or no' issue. As mentioned above, ${ }^{671}$ a highly distinctive mark has a stronger scope of protection than a mark at the bottom end of the scale - an important factor in case the trade mark has to be defended vis-à-vis others. However, strong marks always bear the risk of becoming generic in that, due to their frequent use, their source identification function gradually disappears and is being replaced by a generic usage. ${ }^{672}$

It follows that the issue of concrete distinctiveness should best be evaluated in the course of the SIM by setting out from the question whether the respective mark shows an average degree of distinctiveness. To this average degree the average point score should be assigned. Deviations to the top or bottom of the distinctiveness scale could for example be indicated by either an originally high or low degree of distinctiveness, by frequent or infrequent use of the sign in the relevant market or by a strong or weak visual impression the sign leaves

669 See above at 2.1.2.2.3 for more detail.

670 See above at 5.1.

671 At 5.2.3.1.

672 ÖOGH GRUR Int. 2003, 358 - Sony Walkman II. This is why a trade mark surveillance strategy is important, cf. below at 5.12. 
in the minds of the audience respectively. ${ }^{673}$ Failing distinctiveness does not necessarily mean a zero point score, as this score is reserved for deal breakers and a mature brand may well be able to survive without underlying trade mark protection.

In this context it shall be briefly mentioned that the degree of distinctiveness is not an end in itself. The more a mark tends to be descriptive, the easier it is for the audience to associate it with the respective goods or services due to the content-related link, i.e. the less marketing effort is necessary. Hence, the proprietor's interests of achieving a high degree of distinctiveness and thereby a strong legal scope of protection of the trade mark and of not spending too much on the marketing budget need to be balanced. The decision-making process depends on many factors such as the respective market segment and is a strategic one ideally co-performed by legal and marketing professionals.

\subsubsection{Non-Descriptiveness}

From a trade mark proprietor's point of view, a mark which describes his goods or services is often deemed to be the most attractive one, e.g. 'Supacote' for paint. ${ }^{674}$ However, from a legal perspective, such a sign may be rendered descriptive and therefore lack legal protection. It is seen as inept to perform the main function of a trade mark, i.e. to identify the commercial source of the respective good or service. ${ }^{675}$ The signs which entail the strongest legal protection are those which are invented or fanciful, like 'KODAK' or 'XEROX'.

\subsubsection{The Law in General}

On the European level, descriptiveness is dealt with by Art. 7(1)(c) CTMR. This provision excludes from trade mark protection all those signs which can, in ordinary linguistic use and according to the relevant consmers' view, describe the respective goods or services, either directly or by allusion to one of their intrinsic characteristics. ${ }^{676}$ If this is the case, the interest of others

673 Trade marks frequently utilised and known in the market have a high degree of distinctiveness, cf. ECJ, above fn. 125 - Canon, at no. 18.

674 Murphy, Brand Strategy, p. 130.

675 Above at 2.1.2.1.3. CFI, judgment of 27 February 2002, Case T-219/00, [2002] ECR II-753, Ellos AB v. Office for Harmonisation in the Internal Market (Trade Marks and Designs) (OHIM) - ELLOS, para. 28. 
in keeping the respective sign free to use in connection with the goods or services at issue must prevail. ${ }^{677}$

Like with respect to distinctiveness, the assessment of non-descriptiveness needs to be carried out from the perspective of the average consumer, reasonably well informed and reasonably observant and circumspect. ${ }^{678}$ The application of Art. 7(1)(c) CTMR does not require the respective sign(s) to already be used in a descriptive manner for the goods or services in question at the time of registration. As results from the wording of the provision ("may serve"), it is sufficient that the respetive signs could be used in a descriptive way for the respective goods or services. ${ }^{679}$

It is not always easy to discern whether a sign is actually descriptive. Even the ECJ case law seemed to be in a state of flux, particularly with respect to word combinations. The court took a rather generous view on non-descriptiveness in Baby-dry, ${ }^{680}$ stating that "any perceptible difference" between the word combination sought to be registered and desctiptive usage of the terms in common parlance is sufficient to satisfy the criterion of distinctiveness, even if it is merely a "syntactically unusual juxtaposition". ${ }^{681}$ This basic rule was confirmed, further clarified and slightly narrowed in DOUBLEMINT, ${ }^{682}$ BIOMILD ${ }^{683}$ and Postkantoor. ${ }^{684}$ It is now settled case law that the mere combination of descriptive terms is descriptive on its part, unless the overall impression of the mark at issue is sufficiently far removed from the descriptive parts. ${ }^{685}$ An ambiguous sign is already descriptive in case one of the possible

676 CFI, judgment of 16 March 2006, Case T-322/03, [2006] ECR II-835, Telefon \& Buch Verlagsgesellschaft $\mathrm{mbH}$ v. Office for Harmonisation in the Internal Market (Trade Marks and Designs) (OHIM) - WEISSE SEITEN, para. 90.

677 Cf. e.g. ECJ, supra fn. 636 - WINDSURFING CHIEMSEE, para. 26, as to a geographical indication.

678 To that effect, cf. ECJ, above fn. 644 - Lloyd Schuhfabrik Meyer, para. 26; CFI, judgment of 7 June 2001, Case T-359/99, [2001] ECR II-1645, Deutsche Krankenversicherung AG (DKV) v. Office for Harmonisation in the Internal Market (Trade Marks and Designs) (OHIM) - Euro Health, para. 27.

679 ECJ, above fn. 642 - Postkantoor, para. 97; judgment of 23 October 2003, Case C191/01 P, [2003] ECR I-12447, Office for Harmonisation in the Internal Market (Trade Marks and Designs) v. Wm. Wrigley Jr. Company - Doublemint, para. 32.

680 Judgment of 20 September 2001, Case C-383/99 P, [2001] ECR I-6251, Procter \& Gamble Company v. Office for Harmonisation in the Internal Market (Trade Marks and Designs).

681 At para.s 40 and 43.

682 Supra, fn.679.

683 Judgment of 12 February 2004, Case C-265/00, [2004] ECR I-1699, Campina Melkunie BV v. Benelux-Merkenbureau.

684 Above fn. 642. 
meanings is so understood. ${ }^{686}$

\subsubsection{Value Implications}

Like missing concrete distinctiveness, descriptiveness results in negation of trade mark protection, unless the mark has acquired distinctiveness through use. (Non-)descriptiveness is also linked to the value of the respective brand in a qualitative way, the the dimension of which must be assessed on a caseby-case basis.

Even though all absolute grounds for refusal are per se separate and therefore need to be examined separately, ${ }^{687}$ distinctiveness and non-descriptiveness are linked as both relate to the strength of a mark. Furthermore, both serve the protection of the general public from unjustified exclusivity of rights. Despite they may overlap in practice, ${ }^{688}$ they need to be kept apart from a legal point of view. Hence, despite ECJ and CFI state that concrete distinctiveness of descriptive marks lacks inevitably, ${ }^{68}$ both need to be fully examined in the course of the SIM.

\subsubsection{Graphical Representability}

\subsubsection{The Law in General}

Art. 4 CTMR stipulates that "any signs capable of being represented graphically" may constitute a Community trade mark. This requirement, necessary

685 Cf. e.g. ECJ, above fn. 630 - SAT.2.

686 This was first laid down in DOUBLEMINT which narrows the generous Baby-dry ruling to some extent. It seemed that, after Baby-dry, the mark would not be descriptive in case it had at least one possible non-descriptive meaning. However, it was clarified in DOUBLEMINT (and affirmed in Postkantoor) that the opposite is the case - at least one descriptive meaning renders the sign descriptive.

687 At least the European courts state this in their settled case law, cf. e.g. above fn. 678 - EuroHealth, para. 48; above fn. 648 - EUROCOOL, para. 25.

688 Experience shows that a sign is more likely to lack concrete distinctiveness the more descriptive (and thereby more in need to be kept free) it is, cf. Ströbele/Hacker, Markengesetz, $\S 8$ no. 68. This is one of the factors the expert would have to keep in mind assessing distinctiveness and non-desctiptiveness in the course of the SIM.

689 ECJ, above fn. 642 - Postkantoor, at no. 86; above fn. 683 - BIOMILD, at no. 19; CFI, judgment of 6 November 2007, Case T-28/06, [2007] ECR II-4413, RheinfelsQuellen H. Hövelmann GmbH \& Co. KG v. Office for Harmonisation in the Internal Market (Trade Marks and Designs) (OHIM) - VOM URSPRUNG HER VOLLKOMMEN, at no. 44 . 
in light of the fact that Community trade marks can only be protected by means of registration, can easily be met by traditional signs such as words, pictures, drawings, photographs or a combination thereof.

However, in case of non-traditional signs, especially those which are not directly visually perceivable, the question arises whether and, if yes, how this requirement can be met. At this, considerations that the intended purpose of the requirement of graphical representation is (amongst others) to enable exact determination of the scope of protection of the respective mark so that economic participants are able to acquaint themselves with what their current or potential competitors have trade marked play an important role. ${ }^{690}$

In Sieckmann, a case concerning an olfactory sign, the ECJ handed down its first ruling in this respect, stating that the graphical representation shall particularly consist of "images, lines or characters" and must be "clear, precise, self-contained, easily accessible, intelligible, durable and objective." 691 These requirements have since become settled case law.

Olfactory, audio and abstract colour marks are practically important groups which shall be illuminated in more detail in the following. ${ }^{692}$

\subsubsection{Olfactory Marks}

Smells are of increasing importance in branding since many companies outside the classically smell-focussed perfume industry have discovered the possibility of offering customers a holistic sensual experience. ${ }^{693}$ For instance, international hotel chains attend to creating uniqueness of experience for their customers by using proprietary smells. ${ }^{694}$

690 Marx, Deutsches, europäisches und internationales Markenrecht, at no. 146.

691 ECJ, judgment of 12 December 2002, Case C-273/00, [2002] ECR I-11737, Ralf Sieckmann v. Deutsches Patent- und Markenamt - Sieckmann, para. 55.

692 Further non-traditional signs such as haptic marks, holograms or moving marks will not be mentioned due to the fact that they rarely appear in practice and/or do not constitute interesting legal aspects worth mentioning over and above the marks discussed in the following. Note that the Singapore Treaty, which is a further development of the Trademark Law Treaty (TLT), is the first international instrument of trade mark law explicitly dealing with non-traditional marks (WIPO, WIPO Magazine No. 3, 7 et seq.). The Singapore Treaty was adopted in 2006 and was not yet in force as of January 8, 2007.

693 Branding experts allege that $75 \%$ of human emotions generated daily are triggered by smells yet $83 \%$ of all commercial communication is designed to appeal to the sense of sight only, cf. Manning-Schaffel, Branding that Makes Scents.

694 For example, the US-American Starwood hotel group and Omni hotels are using pro- 
As with any other brand device, its use in branding and marketing, as frequent as it may be, must be distinguished from its ability to be protected as a trade mark. Art. 4 and 7 CTMR contain no provision suggesting that the number of signs eligible for trade mark protection is prima facie limited. In theory, therefore, smells can be protected as trade marks. However, since European courts interpret the requirement of graphical representability quite narrowly compared to some other jurisdictions, the protection of a smell as a trade mark is more or less impossible. As the ECJ stated in Sieckmann, the requirements of graphical representability of an olfactory sign are not satisfied by "a chemical formula, a description in words or the deposit of an odour sample" or by a combination of those elements. ${ }^{695}$

As laid down in Sieckmann, ${ }^{696}$ the current state of the art of technology does not enable a smell to be graphically represented in a way satisfying the relevant criteria. Hence, there are no olfactory trade marks validly registered at OHIM at present. ${ }^{697}$

\subsubsection{Audio Marks}

Like other non-traditional signs, sounds have become increasingly popular in branding in recent years, as companies seek new ways of product positioning and differentiation in light of increasing local and global competition. Deutsche Telekom's five-tone jingle ${ }^{698}$ and Audi's heartbeat sound played at the end of each commercial ${ }^{699}$ are good examples. However, the application of sounds in branding is not confined to advertisements but can also be found as mobile ringtones, background soundscapes in stores, telephone waiting loops and - as forms of internal communication - anywhere within the corporate building, e.g. in elevators. ${ }^{700}$

The ECJ has held that, in case of an audio sign, above criteria for graphical representation are neither met by a description in writing nor by an ono-

prietary scents, cf. Orth, Wie riecht ein Zimmermädchen im Hilton?.

695 Supra, fn. 691 - Sieckmann, para. 72.

696 Fn. 691.

697 As of January 14, 2008, there were seven applications for an olfactory trade mark which had either been refused, withdrawn or the registration of which had lapsed.

698 Registered with OHIM on February 1, 2001 under the file number 001416858.

699 Applied with OHIM under the file number 006111009. Not yet registered as of January $12,2008$.

700 Hirt, Audio-Branding: Klingel-Fluch oder Markensegen?, p. 3. 
matopoeia or a sequence of musical notes without further clarification, as these lack sufficient precision and clarity, which makes it impossible to determine the scope of protection sought. ${ }^{701}$ However, what is sufficient is a stave divided into bars and providing a clef, musical notes and rests with exact notation of their relative value, duration and pitch. ${ }^{702}$ Sonograms have initially been declined but are now accepted by OHIM if they are accompanied by an MP3 file. ${ }^{703}$

\subsubsection{Abstract Colour Marks}

Even though ECJ case law constantly approves of abstract (and sometimes of concrete) distinctiveness of abstract colour marks per se, ${ }^{704}$ the problematic issue with respect to registrability of abstract colours rests with graphical representation. In case of single abstract colours, the requirement of graphical representability can be met by a description in words coupled with a sample. In case sample and description do not constitute a clear, precise, self-contained, easily accessible, intelligible, durable and objective representation, this can be remedied by designating the colour on the basis of an internationally recognised code such as the Pantone code. ${ }^{705}$ With respect to marks consisting of two or more abstract colours, proper graphical representation can only be approved if, in addition to the above requirements, the application contains a systematic arrangement of the colours specifying how they are joined "in a predetermined and uniform way". ${ }^{706}$ Only in this case is the necessary degree of certainty for others in what they need to avoid in order not to infringe achieved.

701 ECJ, judgment of 27 November 2003, Case C-283/01, [2003] ECR I-14313, Shield Mark BV v. Joost Kist h.o.d.n. Memex - Shield Mark/Kist, para.s 59-61.

702 Ibid., para. 62.

703 Office for Harmonization in the Internal Market (Trade Marks and Designs) (OHIM), Tarzans berühmter Schrei.

704 See above at 5.2.3.3; ECJ, above fn. 636 - Libertel and above fn. 661 - Heidelberger Bauchemie.

705 ECJ, above fn. 636 - Libertel, para.s 36-38.

706 ECJ, above fn. 661 - Heidelberger Bauchemie, para. 33. The German Federal Supreme Court (BGH) decided accordingly in Farbmarke gelb/grün II, judgment of 5 October 2006, Case I ZB 86/05, being concerned with the undelienated colour combination green/yellow and accordingly denying sufficient graphical representation. 


\subsubsection{Value Implications}

Unlike non-descriptiveness and distinctiveness, graphical representation is a "yes or no" issue - it either can be fully approved of or not at all. The same must apply, accordingly, for the influence on brand value of this issue.

Hence, existing graphical representability should be awarded a five point score whereas failing graphical representability, i.e. failing trade mark protection, would result in a one or zero point score, depending on wheter or not the issue would be decisive enough to be a deal breaker. ${ }^{707}$

\subsubsection{Findings - Relation to Brand Value}

In case any one of the absolute grounds for refusal of trade mark protection discussed previously is non-existent, protection as a registered trade mark must fail (save in the event of acquired distinctiveness), with the implication that the respective brand needs to obtain and defend its market position without the strong means of trade mark protection - a means both marking out an area in which the proprietor enjoys exclusive freedom to operate the sign(s) at hand and of defending this area by means of developed legal mechanisms.

This proves to be particularly negative for young brands. They have not yet had the chance to gain appreciable internal and external market share and recognition or identity and image respectively - a process which takes time and effort. Hence, they consist of little more than the devices, i.e. the signage, themselves, which would be, in case of failing trade mark protection, free for the public to use (that is according to trade mark law).

In case distinctiveness, non-descriptiveness and graphical representation are approved, their relation to brand value depends on whether they are simply "yes or no" issues, such as the latter, or whether there exists a scale, e.g. from low via average to high distinctiveness. As a general rule, the higher

707 For more information about the meaning of these scores cf. above at 4.1.2.1. Existing graphical representability is very likely to not be worth the maximum score of six points, as this score would mean that the respective issue is so important that the valuation client would do anything to acquire/licence in etc. the asset. Graphical representation is, however, merely one of several requirements for trade mark protection the failure of which has more intense negative effects than its existence has positive ones. 
the degree of distinctiveness, the stronger the mark and the more positive the implication on brand value. In short, the more distinctive the sign, the more valuable the brand. However, it needs to be kept in mind that strong marks are susceptible to becoming generic.

The nature of the sign, be it a traditional one such as a word or one of more recent acceptance like a colour combination, does not have a direct link to brand value but an indirect one. For example, should the registration of olfactory Community trade marks be possible in the future, such marks would be extremely unique and therefore have an above-average potential to be valuable. On the other hand, as with any other non-traditional sign, consumers may in fact not necessarily perceive the smell as indication of commercial origin because they are not used to such items being trade marks or other signs of communication, let alone being allusions to a specific commercial origin. As regards fragrances, this goes in line with the fact that they are deployed in branding in order to influence the audiende subliminally rather that consciously. Hence, factual circumstances speak against olfactory signs to potentially develop a high value. This statement is, in general, also valid with regard to other non-traditional marks.

\subsection{Quantitative Scope of Protection - the Classes}

\subsubsection{System of Trade Mark Classification}

The scope of protection of a registered trade mark is limited to the goods and/or services it is registered for. For purposes of legal certainty, goods and services have been divided into classes. With expiration of the first five years after publication of the registration, a trade mark is subject to cancellation upon request of any third person with respect to all classes it is not being used for. ${ }^{708}$

The system valid in Europe, both on the CTM level ${ }^{709}$ and with regard to national registrations, according to which goods and services are classified, is the International (Nice) Classification of Goods and Services for the Purposes

708 For details on use, see below at 5.7.

709 Although the Eurpean Community is not party to the Nice Agreement (as of July 30, 2008), OHIM has adopted it and makes its use mandatory for applicants. 
of the Registration of Marks (hereafter: Nice Classification). ${ }^{710}$ It is divided into 34 goods and 11 services classes.

\subsubsection{Findings - Relation to Brand Value}

In theory, a mark is more valuable the more classes it is registered for. The more goods or services the trade mark can be used for, the more markets can be served. This makes the scope of protection broader and by the same means blocks the sign's use by others for, in general, the same or similar goods and/or services. However, in order for the registered mark to be valid for all specified classes, it has to be used with respect to all these classes on expiry of the five-year grace period or else it will be subject to cancellation. Therefore, upon taking the decision how many classes the trade mark at hand shall be registered for, it is important to assess the likelihood of the mark de facto being genuinely used for all these classes.

In this context, the fact that registration and maintenance costs rise with an increasing number of specified classes also plays a role. For example, the total OHIM office fee payable to get an individual mark registered for only three classes is $€ 1600$ in case of online filing. ${ }^{711}$ The fee for each class of goods and services exceeding three, in case an individual mark is concerned, is $€ 150 .{ }^{712}$ It follows that the more classes a CTM is registered for, the more costly it becomes if the number of classes exceeds three.

This must be weighed against potential revenue streams estimated to be derived from the use of the mark for all classes concerned. The sum of these incomes must be assessed to be larger than cost in order for the trade mark's

710 It is based on the Nice Agreement Concerning the International Classification of Goods and Services for the Purposes of the Registration of Marks, an international multilateral treaty concluded in 1957 and administered by WIPO. The 9th edition has been in force since January 1st, 2007. The Nice Classification can be accessed on-line at http://www.wipo.int/classifications/nice/en/index.html (last accessed September 23, 2008.)

711 As of June 2008, filing a CTM application for a maximum of three classes costs $€$ 900 and $€ 750$ in case of online filing, Art. 1(1)(a) and (b) Commission Regulation (EC) No 1687/2005 of 14 October 2005 amending Regulation (EC) No 2869/95 on the fees payable to the Office for Harmonization in the Internal Market (Trade Marks and Designs) with regard to adapting certain fees. In addition, the basic fee for the registration of an individual mark for three classes is $€ 850$.

712 Art. 1(1)(c) Regulation 1687/2005, cf. fn. 697. Potential attorney's fees (attorney action is not mandatory for due registration of a CTM) and renewal fees will have to be added. 
quantitative scope of protection to be a positive value influencer.

Exact statements with respect to whether there are certain classes which hint at an especially valuable trade mark or brand cannot be made as this depends on the respective market intended to be covered. More realistically, the expert assessing the legal dimension will over time be able to discern essential classes for each industry branch, the lacking registration for which would have a negative impact on value, and non-essential ones.

\subsection{Geographic Scope of Protection}

\subsubsection{The Law}

Trade mark law is characterised by the principle of territoriality, which means that a trade mark is, in general, only valid in the countries for which it has been registered. The Community trade mark constitutes a peculiarity and alleviation in this connection as it covers all EU Member States with merely one registration (the downside being that it can be vitiated with effect for the complete EU territory by just one successful attack in one Member State).

The Madrid system of international trade mark registration is frequently utilised and shall therefore be briefly mentioned. ${ }^{713}$ The Madrid Agreement Concerning the International Registration of Marks and the relating Protocol ${ }^{714}$ have made it possible, once the proprietor holds a trade mark in one Contracting Party (including the EU), to register the same mark, via the International Bureau of WIPO, in one, several or all of the other Contracting Parties, by means of a single application in one language. Contrary to the European Community trade mark, the Madrid system does not give the proprietor one mark which is equally protected in all member countries but merely a unified application and registration system which facilitates simultaneous registration of a mark in several countries. ${ }^{715}$ The international

713 More on registration of trade marks through the Madrid System below at 5.6.2.2. In addition, detailed information can for instance be found in WIPO, Guide to the International Registration of Marks under the Madrid Agreement and the Madrid Protocol and Marx, Deutsches, europäisches und internationales Markenrecht, no.s 1409 et seq.

714 Cf. fn. 118.

715 This process is similar to the Patent Cooperation Treaty (PCT) procedure with regard to patents. 
registration obtained via the Madrid system is equal to a bundle of national registrations. This gives rise to potentially differing assessments of the same sign, despite certain harmonisation of substantive trade mark law on supranational and international levels. The upside for the proprietor is that one opposition bears the power to merely annul the trade mark in one country. ${ }^{716}$

The point of geographic scope of protection nicely shows how legal and strategic issues can be intertwined, as the issue for which countries protection is sought should be addressed in accordance with the overall business strategy before implementation of the respective strategic decision by way of legal means. Like in the case of the quantitative scope of protection, such strategic considerations need to include a cost-benefit analysis for each respective territory envisaged. In consequence, the experts assessing the legal and the business strategic dimension of the SIM need to attend to not operationalising this same issue twice. A fact statement relating to whether the geographic scope of protection of the respective trade mark is adequate can only be included in either of these dimensions.

\subsubsection{Findings - Relation to Brand Value}

Similar to the quantitative scope of protection, the general rule is that a trade mark is more valuable the more countries it covers. The more territories the proprietor enjoys freedom to operate in, the more markets he or she is able to serve. However, it is also essential with respect to the geographic scope of protection to balance benefit and cost, i.e. the estimated financial advantage from the number of countries in which protection is achieved and the cost of such protection.

Therefore, the most reasonable question to assess with respect to geographic scope of protection is whether the proprietor has registered the respective trade mark in all necessary territories (or, in case of mere applications, whether such registration can be reasonably expected). A country is necessary in this sense if the title holder has entered or reasonably plans to enter this geographic market with goods and/or services marked with a brand or brands containing the trade mark in question. For instance, a point score

716 An exception to this rule exists during the first five years from the date of the international registration, in which a central attack is still possible - with different consequences under the Madrid Agreement and Protocol. 
below average would have to be the consequence in case registration is not ensured for all necessary countries.

\subsection{Temporal Scope of Protection}

\subsubsection{Beginning and Duration of Protection}

Protection starts - upon correct registration - retroactively on the day of application. $^{717}$

The statutory term of protection of a registered trade mark in Europe is ten years from the date of application. ${ }^{718}$ However, a trade mark is the only intellectual property right which can be infinitely renewed (upon application and payment of a renewal fee).

\subsubsection{Findings - Relation to Brand Value}

The interrelation of the duration of trade mark protection and brand value could be particularly distinct with regard to payment of renewal fees. The fact that a proprietor renews the term of a certain trade mark shows that to him it has, or should have, at least a value as high as the respective renewal fee. However, the link between trade mark renewal and brand value is not as direct as it is being discussed with respect to patent renewal and patent value. ${ }^{719}$ This is due to two circumstances which are rooted in the specific nature of brands: firstly, a brand is more than the legal construct trade mark and can exist without legal protection of its signage (even though this would be rather difficult in practice) ${ }^{720}$ Secondly, trade mark protection can exist

717 Even though the formal application is the most common means of attaining a trade mark right, trade mark protection can also be reached by accrual of notoriety (Art. $6^{\text {bis }}$ Paris Convention - well-known marks) or, on the national level, for instance in Germany, through use (Verkehrsgeltung, § 4 no. 2 MarkenG). As explained above, the work at hand focuses on registered trade marks, as harmonised European trade mark legislation solely deals with this type of trade mark, which is also the most common one, cf. above at 5.1 with fn. 622 .

718 Art. 46 CTMR.

719 As to the correlation between payment of patent renewal fees and patent value cf. e.g. Harhoff/Scherer/Vopel, Exploring the tail of patented invention value distributions, Lanjouw, 65 The Review of Economic Studies 671 (1998), and Pakes, 54 Econometrica No. 4, 755 (1986).

720 Cf. e.g. above at 5.1. 
outside the registers in the case of well-known marks and use marks, in the case of which the respective trade mark cannot be officially renewed..$^{721}$

Hence, the assumption that the value of a brand rises the more often the corresponding trade mark(s) is/are renewed does offer a certain logic yet must be limited to registered trade marks and be made with the specific nature of brands in mind.

It follows that the temporal scope of protection is of little importance for assessment of brand value in the years before the first renewal is due. During this time, temporal scope of trade mark protection should not be an issue in the course of brand valuation provided that the mere existance of the trade mark concerned is checked.

\subsection{Origin of Trade Mark Protection: Registered Trade Marks}

\subsubsection{Introductory Remarks}

As just mentioned, it needs to be scrutinised whether the respective trade mark is correctly registered or, at earlier stages, whether the application is correct (apart from cases of trade marks acquired through use or well-known marks, cf. infra at 5.7).

A good example of how important an early registration of a mark, if desired by the proprietor's brand strategy, and according cooperation between the legal and brand management departments of a business are, is the fact that the internet auction company eBay did not trademark its slogan "3...2...1...meins!" (3...2...1...mine!) before extensively using it from 2003 and spending $€ 60$ million on advertising in this regard (between October 2003 and January 2005 alone). When eBay wanted to trademark the slogan, approximately four months after starting the advertising campain, it had to find out that an almost identical slogan, "3..2..1..meins!" (merely with one dot less between the numbers) had been trademarked a little earlier for conflicting goods classes. ${ }^{722}$ This allows the proprietor of the earlier mark, who was

721 Infra at 5.7.

722 Sine autore, Markenrechtskrimi um die 60-Millionen-Euro Marke "3..2..1..meins!" and sine autore, Marktverwirrung um "3..2..1..meins!"?. The trade mark "3..2..1..meins!" was registered with the German Patent and Trade Mark Office on August 6, 2004 as DE30404403 and was still in force as of October 30, 2009. 
utilising the claim on liquor and a board game, to take considerable advantage of eBay's high profile and marketing investment (unless his registration is invalidated for bad faith ot other reasons, which was not the case as of October 30, 2009). eBay, in turn, is not able to fully strategically develop or to otherwise take advantage of their slogan, which minimises return on investment and therefore the value of the brand.

\subsubsection{International, European and National Registration Systems}

In order to show the procedure by which a trade mark registration can be obtained, the German, international and European Union systems shall be introduced in the following.

\subsubsection{National Registration - Example Germany}

The formal prerequisites for registering a sign as a trade mark with the German Patent and Trade Mark Office (DPMA) are mainly laid down in $\S \S 4$ no. 1, 32 et seq. MarkenG, the Markenverordnung, ${ }^{723}$ the latter being a German by-law concretising the implementation of the MarkenG, and the DPMA-Verordnung, ${ }^{724}$ a by-law regulating organisation and capacities of and procedures within the DPMA. A registration is only made if a qualified proprietor $^{725}$ applies for registration of a trademarkable sign, i.e. one the registration of which no absolute grounds for refusal of trade mark protection ${ }^{726}$ are opposed to, and pays all necessary office fees (see below). Any natural or legal person may apply for a trade mark and does not need to be represented by an advocate in doing so.

An application must primarily specify the applicant, the trade mark form (e.g. word mark, three-dimensional mark etc.), reproduce the sign for which protection is sought and include a list of goods and services for which the trade mark shall be registered, §§ 32(2) MarkenG, 3(1) MarkenV. Using the application form provided by DPMA is mandatory, cf. § 2(1) MarkenV. It can be handed in personally, by mail, telefax or electronically. ${ }^{727}$

723 Verordnung zur Ausführung des Markengesetzes (Markenverordnung - MarkenV) vom 11. Mai 2004 (BGBl. I p. 872).

724 Verordnung über das Deutsche Patent- und Markenamt (DPMAV) vom 1. April 2004 (BGBl. I p. 514).

725 Cf. infra at 5.9.

726 Cf. supra, 5.2 . 
Office fees for registration of a trade mark with the DPMA amount to $€$ 300 for up to three classes ${ }^{728}$ in case of paper filing ( $€ 290$ in the event of electronic filing). ${ }^{729}$ They are due upon filing, § 3(1) PatKostG. Applying for each further class costs $€ 100$. If desired, the applicant may pay another $€$ 200 to fast-track the examination process ( $\S 38$ MarkenG, 2(1) PatKostG and no. 331500 in the PatKostG schedule of fees).

The trade mark examiner first checks whether the application comprises all necessary information. In case the information required by $\S \S 32(2)$ MarkenG, 3(1) MarkenV is not completely specified in the application, the day the application was handed in will not be recognised as a valid application and priority date. Instead, the application and thereby the priority date will be the one on which DPMA receives this information in its entirety. All other required data can be handed in later without priority shifting. In both cases, the missing information must be handed in before a deadline set by DPMA. Otherwise, the application will be deemed to not have been made or rejected respectively.

An application of a trade mark with a valid application date establishes a right to registration of the respective sign as a trade mark if no absolute grounds for refusal of trade mark protection are opposed, §33(2) MarkenG. Hence, the examiner next scrutinises ex officio whether such absolute grounds are existent, $\S 37(1)$ MarkenG. These grounds are laid down in $\S \S 3,8$ and 10 MarkenG. Contrary to relative grounds for refusal of trade mark protection, absolute grounds do not refer to other trade mark proprietors' rights. They comprise issues such as capability of the sign to be represented graphically, distinctive character of the sign, deceptive character of the sign or whether the respective sign is contrary to public policy or accepted principles of morality. The most important absolute grounds for refusal are examined above at 5.2.

If no absolute ground for refusal is affirmed, the respective sign will be registered as a trade mark and published in the Markenblatt (Trade Mark Jour-

727 Electronic trade mark filing has been possible since October 2006. Contrary to an application for a Community Trade Mark, electronic filing of a German trade mark application demands use of a qualified electronic signature subject to the German Signaturgesetz (Electronic Signature Act) (Gesetz über Rahmenbedingungen für elektronische Signaturen vom 16. Mai 2001 (BGBl I p. 876) - SigG), § 12 DPMAV.

728 As to the trade mark classification system cf. above at 5.3.

729 DPMA fees are laid down in the Patentkostengesetz (Patent Cost Act) and the schedule of fees in its annex: Gesetz über die Kosten des Deutschen Patent- und Markenamts und des Bundespatentgerichts vom 13. Dezember 2001 (BGBl I p. 3656) - PatKostG. 
nal - since July 2004 exclusively in electronic form), $\S \S 41$ MarkenG, 27, 28 MarkenV.

\subsubsection{The Madrid System}

Due to territoriality of trade mark protection, ${ }^{730}$ each nationally registered trade mark is only effective in the country of registration. In case protection in several jurisdictions is sought, however, an existing national application or registration can be and often is used as a starting point for registrations in one or several other jurisdictions without having to deal with the respective national offices directly, instead of registering a trade mark with each national office of the respective desired countries.

Such modus operandi is made possible by the international registration system established by the Madrid Agreement Concerning the Internaional Registration of Marks ("Madrid Agreement" - in force since 1892) and the Protocol Relating to the Madrid Agreement Concerning the Internaional Registration of Marks ("Madrid Protocol" - in force since 1996) - the "Madrid Union" or "Madrid System". ${ }^{731}$ Madrid Agreement and Madrid Protocol are being supplemented by the Common Regulations under the Madrid Agreement Concerning the International Registration of Marks and the Protocol Relating to that Agreement ("Common Regulations" - in force since 1996), which govern particulars of the international registration procedure. The Madrid Union allows a trade mark applicant or proprietor to obtain and maintain trade mark protection in up to 83 countries and the European Union ${ }^{732}$ by means of one single application in one language. It is administered by the International Bureau of WIPO in Geneva, Switzerland.

Madrid Agreement and Madrid Protocol are two formally separate international treaties. As of December 1, 2009, three Member States of the Madrid Union were merely contracting parties to the Madrid Agreement, a number of

730 Cf. supra at 5.4.1.

731 The Madrid Union consists of special agreements within the meaning of Art. 19 Paris Convention and is therefore a "Special Union", Art. 1(1) Madrid Agreement. Any state which is a party to the Paris Convention may become party to the Madrid Agreement and/or the Madrid Protocol, cf. Art. 14(1) Madrid Agreement and Art. 14(1)(a) Madrid Protocol.

732 This is the status of Madrid Union members, i.e. contracting parties to the Madrid Agreement and/or the Madrid Protocol, as of December 1, 2009, cf. http://www.wi po.int/export/sites/www/treaties/en/documents/pdf/madrid_marks.pdf. 
countries and the European Union had ratified the Madrid Protocol only and the majority of Madrid System members were parties to both. Therefore, the implications of these three different types of Madrid Union membership on the international trade mark registration procedure shall be briefly discussed in the following.

\subsection{International Registration Procedure}

The Madrid Agreement enables a national of a contracting state who is a proprietor of a registration (but not an application) there to submit a single international application to his national trade mark office, which then forwards it to the WIPO International Office, specifying those countries party to the Madrid Agreement in which he wishes to secure a registration. The priority of the base (i.e. the earlier national) filing can be relied upon if the proprietor files the international application within six months from the date of the earlier application, cf. Art. 4(2) Madrid Agreement and Art. 4A - 4C Paris Convention.

Once the international registration is completed, it has, in each designated country, the same effect as if it had been registered locally, Art. 4(1) Madrid Agreement, provided that the respective national offices do not deny protection. As the Madrid System does not govern substantive trade mark law but registration matters only, content and scope of trade mark protection are subject to the laws of the respective countries of protection. Hence, Art. 5(1) Madrid Agreement provides that the national offices of the contracting parties have - within one year from the date of the international registration - the right to deny protection of the respective mark on grounds applicable to national registrations. In case of such denial, the proprietor has the same remedies as if he had filed the application directly before the national office concerned, cf. Art. 5(3) Madrid Agreement.

According to Art. 6(1) Madrid Agreement, a registration of a trade mark at the International Bureau is valid for 20 years from the date of registration. Within the first five years, the international registration is dependent on the existence of the earlier national registration, Art. 6(2) and (3) Madrid Agreement. This means that the protection resulting from the international registration is dispensed with in case the base registration is successfully attacked by a third party (the so-called "central attack") or no longer enjoys 
legal protection on other grounds at any time during the period of five years from the date of international registration. The same legal consequence applies in case the legal protection of the base registration ceases after this five-year period but as the result of an action begun before the end of this period. In this situation, the proprietor is free to apply for trade mark protection before each respective national office but loses the priority of the international application - a serious risk and drawback of the international registration system under the Madrid Agreement.

The main advantage of the Madrid Agreement was the introduction of a unified registration system which allows proprietors to save considerable amounts of time and money through parallel registrations in several countries by means of one standardised international registration. ${ }^{733}$ The formalities are considerably reduced compared to the alternative route of applying for trade mark protection in several different jurisdictions. The advantages the Madrid Agreement brings about do not only affect proprietors prior to but also after registration. For instance, the territorial scope of protection of a trade mark registered by means of the Madrid Agreement can be extended after registration, cf. Art. $3^{\text {ter }}$ Madrid Agreement. Changes such as renewals (Art. 7 Madrid Agreement) can be made by one single application instead of applying with each national office.

However, the Madrid Agreement met with widespread criticism and was never able to achieve worldwide acceptance. For instance, countries like the USA, the United Kingdom and Japan, which are now parties to the Madrid Protocol, never ratified the Madrid Agreement. ${ }^{734}$

\subsection{The Madrid Protocol}

733 For more details on the procedures under the Madrid System cf. World Intellectual Property Organization, Guide to the International Registration of Marks under the Madrid Agreement and the Madrid Protocol.

734 There were various reasons for this reluctance. Apart from the problem just mentioned, one was that the countries the national laws of which prescribed a comparatively extensive pre-registration examination feared the flooding of their registers by marks originating from countries which have a rather liberal registration system without indepth examination before a trade mark is registered, cf. Jaeger-Lenz/Freiwald, GRUR $2005,118,120$. The fact that a home registration instead of a mere application is needed was also perceived to be a major drawback, cf. Michaels, A Practical Guide to Trade Mark Law, p. 99. In addition, some national offices disliked the rigid system of basic, supplementary and complementary fees (Art. 8(2) (a)-(c) Madrid Agreement), including the fact that these fees were oftentimes lower than desired. 
The Madrid Protocol was adopted as a result of this unsatisfactory situation and in order to create a link to the emerging Community trade mark system. ${ }^{735}$ Whereas originally Art. $9^{\text {sexies }}$ Madrid Protol stipulated that the Madrid Protocol shall have no effect between contracting parties of both Madrid covenants, this safeguard provision was repealed in 2008. Hence, the Madrid Protocol now exclusively governs international applications made through an Office of origin of either a state bound by the Madrid Protocol but not by the Madrid Agreement, or of a Contracting Organization, or of a state bound by both Madrid Agreement and Madrid Protocol, where the application does not designate any state which is exclusively bound by the Madrid Agreement, Art. 2 Madrid Protocol, Rule 1(ix) Common Regulations. These three alternatives constitute the vast majority of all Madrid Union cases in practice. ${ }^{736}$

The fundamental provisions of the Madrid Protocol correspond to those of the Madrid Agreement. Therefore, the main features of the international registration system under the Madrid Agreement as just outlined also exist under the Madrid Protocol. ${ }^{737}$ However, there are a number of substantial differences between the two treaties.

The main differences to the Madrid Agreement are the following: Firstly, an international registration can now be effected based on a home application or registration instead of a registration only, cf. Art. 2 Madrid Protocol.

Secondly, the contracting parties now have the choice to either receive a share

735 Marx, Deutsches, europäisches und internationales Markenrecht, at no. 1416.

736 The Madrid Agreement has become less important since the rescindment of the safeguard clause. International applications governed exclusively by the Madrid Agreement are those whose Office of origin is the office of either a state bound by the Madrid Agreement only (which could be, as of December 1, 2009, Algeria, Kazakhstan or Tajikistan) or a state bound by Madrid Agreement or Protocol and the application designates only states and all these states are bound by the Madrid Agreement only, cf. Art. 1(2) and (3), Art. 2 Madrid Agreement, Rule 1(viii) Common Regulations. Registration procedures under both the Madrid Agreement and the Protocol also occur infrequently. International applications governed by both treaties are those whose Office of origin is the office of a state bound by both Agreement and Protocol and which is based on a registration (not an application) and contains the designations of at least one state bound by the Agreement only as well as of at least one state bound by the Protocol, whether or not that state is also bound by the Agreement, or of at least one Contracting Organization, cf. Art. 1(2) and (3), Art. 2 Madrid Agreement, Art. 2 Madrid Protocol and Rule 1(x) Common Regulations.

737 For more detailed information on the Madrid System see World Intellectual Property Organization, Guide to the International Registration of Marks under the Madrid Agreement and the Madrid Protocol. 
in the revenue derived from the traditional supplementary and complementary fees or charge a so-called "individual fee" instead, cf. Art. 8(7)(a) Madrid Protocol. The latter option is widely made use of and the individual fees are often considerably higher than the supplementary and complementary fees (which are currently sFR 100 each), ${ }^{738}$ yet at most the individual fees are allowed to be as high as the respective national fees.

Thirdly, Art. 5(2)(b) Madrid Protocol allows the contracting parties to extend the one-year period within which they have the opportunity to deny protection of the respective mark on grounds pertaining to applications before their national offices (see above at 5.6.2.2.1) to 18 months.

A change with the potential to save the proprietors considerable amounts of time and money was made in the language provisions: Whereas international applications under the Madrid Agreement must be made in French, international applications under the Madrid Protocol may also be filed in English or Spanish, cf. Rule 6(1) Common Regulations.

The temporal scope of protection of a trade mark registered under the Madrid Protocol has been adapted to the rules in most other jurisdictions and is now ten years with the possibility of infinite renewal, Art. 6(1) Madrid Protocol.

The accession of the European Union to the Madrid Protocol was allowed for by a new provision specifying that an intergovernmental organisation may become a party if at least one of its member states is party to the Paris Convention and the organisation has a regional trade mark office, Art. 14(1)(b) Madrid Protocol. It has been effective since October 1, 2004, and created a link between the Madrid and the Community trade mark system. Applicants and registrants of a Community trade mark now have the opportunity to apply for international protection and proprietors of international applications or registrations are entitled to apply for Community trade mark protection under the Madrid Protocol. The former alternative is rather risky as the international registration is dependent on the base registration during the first five years and a Community trade mark can even be derailed in cases where the respective ground for refusal of protection exists in only one of the

738 For instance, in cases of designations made in the international application or subsequent to the international registration, the U.S. individual fee amounts to sFR 337 for one class and for each additional class, the United Kingdom individual fee amounts to sFR 295 for one class and sFR 82 for each additional class and the European Union individual fee is sFR 1311 for one class and 226 for each additional class (save for cases of collective marks). Germany has not chosen to charge individual fees as yet. 
currently 27 EU Member States. ${ }^{739}$ However, applying for Community trade mark protection in the course of an international registration is attractive: the international registration route is less costly than applying for a Community trade mark and provides for the possibility to opt back to a designation of individual EU Member States via the Madrid System should the Community trade mark application fail, cf. Art. 154(1)(b) CTMR. The proprietor can thus secure protection of the internationally registered trade mark in the EU while using the administrative advantages of the Madrid System. ${ }^{740}$

\subsubsection{Community Trade Mark Registration}

The Community trade mark (CTM) system, in force since April 1, 1996, allows for trade mark protection in all (currently 27) Member States of the European Union by means of one single registration with the Office for Harmonization in the Internal Market (Trade Marks and Designs) (OHIM) in Alicante, Spain.

Particulars of the formal requirements of a trade mark registration with OHIM are laid down in the Regulation implementing the Community trade mark Regulation (Implementing Regulation). ${ }^{741}$ Unlike all other communication with OHIM, the CTM application can be filed with either the respective national office or with OHIM. In order to secure the desired filing date, the basic fee and, if applicable, a class fee for each class exceeding three must be paid within one month from handing in the application, Art. 4 Implementing Regulation. Community trade mark applications with OHIM may be filed electronically, which is not only the fastest, but also the cheapest filing method: whereas the current basic fee for standard paper filing is EUR 1050, it is EUR 900 in case of e-filing. ${ }^{72}$

According to Art. 29-32 CTMR, proprietors of older trade marks or applications made in or for a Member State of the Paris Convention or the Agree-

739 Cf. above at 5.4.1.

740 Hasselblatt (ed.), Münchener Anwaltshandbuch Gewerblicher Rechtsschutz, § 37 at no.s 11 and 81.

741 Commission Regulation (EC) No 2868/95 of 13 December 1995 implementing Council Regulation (EC) No 40/94 on the Community trade mark.

742 Commission Regulation (EC) No 355/2009 of 31 March 2009 amending Regulation (EC) No 2869/95 on the fees payable to the Office for Harmonization in the Internal Market (Trade Marks and Designs) and Regulation (EC) No 2868/95 implementing Council Regulation (EC) No 40/94 on the Community trade mark, Art. 1 (1). 
ment establishing the WTO may, in order to file a Community trade mark application, claim priority during six months from the date of filing of the first application. This requires that the later application is made for the same mark and for either identical goods or services or goods or services comprised by the first application. The effect of the priority right is that the application of the Community trade mark is deemed to have been made on the priority date for the purposes of establishing which rights take precedence, Art. 31 CTMR.

A particularity of the Community trade mark system is the option to claim seniority of an earlier national trade mark for purposes of a respective Community trade mark application according to Art. 34 and 35 CTMR. Provided that the desired Community trade mark is identical with the older national mark and the goods or services applied for are identical with or contained within those for which the earlier national mark has been registered, the proprietor is, even if the earlier national mark is surrendered or has lapsed, deemed to continue having the same rights as if the earlier mark had continued to be in force, Art. 34(1) and (2) CMTR. The option to claim seniority aims at inducing proprietors of national trade marks to surrender these rights in favour of corresponding Community trade marks. ${ }^{743}$

Apart from general registration requirements such as payment of fees, OHIM particularly examines title, classification of the goods and services according to the Nice Classification and absolute grounds for refusal of trade mark protection, Art. 26(1), 27 and 36 CTMR. Both natural and legal persons may apply for a Community trade mark, as both are allowed to be trade mark proprietors, Art. 5 CTMR. If the aforementioned requirements are met, OHIM issues a Community search report containing older Community trade marks or applications which may be used to challenge the application at hand as relative grounds for refusal of trade mark protection. The application itself is published, at the earliest, one month after OHIM has transmitted the search report to the applicant, Art. 39(6), 40 CTMR.

Third persons then have the opportunity to make observations based on absolute grounds for refusal of trade mark protection (which OHIM examines ex officio) or to file an opposition based on relative grounds for refusal, Art. 41-43 CTMR. Depending on the outcome of such proceedings, the application

743 Marx, Deutsches, europisches und internationales Markenrecht, at no. 1221. 
is either rejected or the respective trade mark is registered if the registration fee has been duly paid, Art. 45 CTMR, Rule 23 (2) Implementing Regulation.

A Community trade mark is - provided that the use requirements are met valid for ten years from the filing date with the possibility of infinite renewal, Art. 46 CTMR.

\subsubsection{Relation to Brand Value}

Proper trade mark registration is a "yes or no" issue - it either exists or not. Its absence will, in most cases other than of trade marks acquired through use or well-known marks, be a serious value detractor since this crucial factor of securing legal freedom to operate for the corresponding brand is missing. The eBay example mentioned above at 5.6.1 illuminates this. Furthermore, failing trade mark protection can even be an issue of sheer existence or survival of the brand, especially if it is still juvenile and does not consist of much more than the signs for which trade mark protection is sought. ${ }^{744}$

Whereas failing trade mark registration is generally a clear value detractor or even value destructor, affirmed registration is not a mirror image to the extent that it is as much a value enhancer as failing registration is a detractor. Rather, it is, since it creates legal scarcity, a basic prerequisite for most brands to be able to build value at all, ${ }^{74}$ but not a guarantee that this will happen at all, let alone to a noteworthy degree.

What is more, registration fees ${ }^{746}$ and possible attorney's fees ${ }^{747}$ play a dual role with respect to trade mark and brand value. Firstly, within the overall branding strategy, they need to be weighed against the benefit a registered trade mark entails. Such cost-benefit analysis should be carried out on a regular strategic basis, the respective outcome of which would then be implemented by (refraining from) registration. For instance, as a rule of thumb, one can say that registration of a Community trade mark is expedient in case the proprietor's business activities extend to three or more EU Member States or are likely to do so in the foreseeable future. ${ }^{748}$

744 Cf. supra at 5.1.

745 Cf. supra at 2.1.3.3.7.

746 Above at 5.3.2.

747 Representation by an attorney is not mandatory in order to get a German or a Community trade mark registered. 
Secondly, once the trade mark is registered, all costs accrued in this context need to be subtracted from the (expected) revenue streams derived from the corresponding brand in order to reach the 'net effect' of these value streams. ${ }^{74}$ This will be carried out in the course of the DCF and decision tree analysis. ${ }^{750}$

In the course of the legal dimension, correct registration is an item which merely needs to be ticked off in terms of 'yes' or 'no'. Failing registration is a considerable value detractor (unless the mark is well-known or acquired through use), since the respective brand must be managed without the underlying legal (trade mark) freedom to operate. Existing registration, however, is not automatically a considerable value enhancer but a mere value enabler, since it secures a legal side of brand-related freedom to operate but does not show how well the brand is in fact utilised to enhance its value.

\subsection{Origin of Trade Mark Protection: Non-Registered Trade Marks - Trade Marks Acquired Through Use and Well-Known Marks}

\subsubsection{Introductory Remarks}

Not only do trade marks enjoy legal protection by means of formal registration, but also - without being registered - as trade marks acquired through use or as well-known marks. The quality of legal protection of registered marks, trade marks acquired through use (or 'use marks') and well-known marks is generally the same with respect to the proprietor's rights to exclusive use of the mark - if, where and as long as the respective mark enjoys protection. However, there exist differences regarding, inter alia, priority and territorial scope of protection ${ }^{751}$ as well as the implications of these legal issues on brand value. Therefore, the legal framework with regard to trade marks acquired through use and well-known marks shall be briefly introduced in the following paragraphs. ${ }^{752}$

748 Hasselblatt, Münchener Anwalts Handbuch Gewerblicher Rechtsschutz, § 38 at no. 241.

749 Similar to Spannagl/Biesalski, Brand Rating-Modell, p. 86.

750 Cf. above at 3.2.2.1.3.

751 Marx, Deutsches, europäisches und internationales Markenrecht, at no. 382.

752 As mentioned above, this work mainly deals with registered trade marks. More on 
It shall be mentioned in advance that there exists no piece of EU legislation harmonising the law of use marks and/or well-known trade marks on a European level. Rather, European legislation takes trade marks acquired through use into account "only in regard to the relationship between them and trade marks acquired by registration" ${ }^{753}$ Hence, one's attention needs to be turned to national legislation (this work will use the example of German law) and international conventions, most notably the Paris Convention and the TRIPs Agreement, the latter two being incorporated into domestic laws.

\subsubsection{Well-Known Marks}

Well-known marks, i.e. unregistered (or registered) marks that are widely known in the marketplace, are protected through implementation of the respective provisions of the Paris Convention and the TRIPs Agreement into national laws.

Art. $6^{\text {bis }}$ Paris Convention creates an international minimum standard of protection of well-known marks against registration or use on identical or similar goods and against trade marks which are reproductions, imitations or translations. ${ }^{754}$ This basically corresponds to the level of protection thitherto awarded to registered trade marks only and is therefore of particular importance for unregistered trade marks. Art. $6^{\text {bis }}$ Paris Convention does not require that the sign in question actually be in use in the country concerned, provided that the sign is well-known there (thus, the notoriety of the sign concerned must exist in the country in question but can be based on use in a foreign country). Neither does it define when a mark is well-known in this sense but leaves this question for the national lawmakers and courts to decide. In most countries, a rather high degree of notoriety is required, ranging from $60 \%$ to $80 \% .{ }^{755}$ Such fame must be the result of a communication

the protection of non-registered trade marks can be found at Götting, IIC 2000, 389; Marx, Deutsches, europäisches und internationales Markenrecht, at no.s 584 et seq.; Phillips, Trade Mark Law: A Practical Anatomy, pp. 393 et seq.

753 Cf. Recital four of the CTMD. The CTMR, for instance, refers to such unregistered trade marks in Art. 8(2)(c) which deals with relative grounds for refusal of protection based on conflicting earlier rights. According to Art. 8(2)(c) CTMR, registration of a Community trade mark must be denied in case, inter alia, it conflicts with a national mark which is well-known pursuant to Art. $6^{\text {bis }}$ Paris Convention.

754 Lackert/Perry, Building and enforcing intellectual property value 2008, 63, 64.

755 Götting, IIC 2000, 389, 406. 
process between seller and target audience as a result of which the mark is perceived as a sign of origin of the respective goods or services.

The later TRIPs Agreement extends the application of the Paris Convention to all WTO Member States pursuant to its Art. 2(1) which specifies that WTO Members "shall comply with Articles 1 through 12, and Article 19, of the Paris Convention (1967)". Hence, the TRIPs Agreement incorporates, through its Art. 2, all substantive provisions of the Paris Convention, making them binding on all WTO Members, whether or not they are signatories of the Paris Convention. ${ }^{756}$

Furthermore, Art. 16(2) TRIPs extends the scope of Art. $6^{\text {bis }}$ Paris Convention in a number of ways. For instance, it extends Art. $6^{\text {bis }}$ Paris Convention to protect service marks. Unlike Art. $6^{\text {bis }}$ Paris Convention, Art. 16(2) TRIPs provides some guidance as to under which circumstances a mark is well-known. According to this provision, one shall take into account "the knowledge of the trade mark in the relevant sector of the public, including knowledge in the Member [i.e. Member State to the WTO, A/N] concerned which has been obtained as a result of the promotion of the trade mark.". The mere mention of promotion means that the respective mark need not actually be used to the extent that there are sales of marked goods or services in the respective country. ${ }^{757}$

The priority of well-known marks is more difficult to detect than the one of registered trade marks. Whereas the priority of registered marks depends on the date of application, the point in time at which a mark becomes wellknown is decisive for its protection under Art. $6^{\text {bis }}$ Paris Convention (in countries where this provision is held to be self-executing) and the related domestic laws respectively. ${ }^{758}$ Evidence of a trade mark application can be

756 This is named the "Paris Plus Approach", cf. Kur, GRUR Int. 1994, 987, 989.

757 In addition, Art. 16(3) TRIPs extends the application of Art. $6^{\text {bis }}$ Paris Convention to the protection of registered well-known trade marks from unauthorised use of the mark on non-competing, unrelated goods or services provided that this "would indicate a connection between those goods or services and the owner of the registered trade mark and provided that the interests of the owner of the registered trade mark are likely to be damaged by such use.". Herewith, the protection of well-known marks is extended beyond similarity, the traditional realm of protection of registered trade marks. Hence, a registered well-known mark is protected from its use on dissimilar goods or services in a manner which blurs or tarnishes its unique drawing power a central component of the value of the well-known mark in question. This section 5.7 deals with the protection of unregistered marks only. For more on protection of registered trade marks beyond cases of double identity and likelihood of confusion cf. below at 5.12 . 
easily provided, yet proprietors of well-known marks often encounter factual difficulties to prove the priority of the mark in question, as they are forced to rely upon not merely sales and advertising figures but also, for instance, market surveys with past-related questions or reverse projection of current empirical data. ${ }^{759}$

\subsubsection{Trade Marks Acquired Through Use}

According to $\S 4$ Nr. 2 MarkenG, a sign can attain protection as a trade mark in case it is used in trade or commerce and this use has led to a recognition by the relevant public that the sign is a mark of the claimant (Verkehrsgeltung). ${ }^{760}$ As this definition suggests, a trade mark acquired through use $\mathrm{e}^{761}$ does not accrue by merely initialising use of a sign in trade or commerce. Rather, trade mark protection must be 'acquired', i.e. such use must lead to connection of the respective signage with a certain meaning by the target audience, enabled by continued usage of the sign in trade or commerce. Hence, use marks are, like well-known marks, the result of a communication process between proprietor (or licencee/franchisee) and target audience in which the audience has learned to perceive the respective signage as an indication of origin of the marked goods and/or services. ${ }^{762}$

Whereas the object of protection in case of a registered trade mark is the sign as shown in the register, the use mark is protected as it is in fact being used in trade or commerce. Also, it needs to be precisely determined for which goods and/or services the sign at issue can claim protection as a use mark. Contrary to a trade mark registered with the German Patent and Trade Mark Office, a use mark's protection does not automatically acccrue for the whole German territory. Rather, one must identify the region in which the respective sign is used - this can be Germany at large or merely a certain region, for instance one or several Bundesländer (federal states). ${ }^{763}$

758 For instance, $\S 4$ Nr. 3 MarkenG refers to Art. $6^{\text {bis }}$ Paris Convention as laying down one of three possibilities for trade mark protection to accrue (next to registration and secondary meaning).

759 Marx, Deutsches, europäisches und internationales Markenrecht, at no. 384 .

760 This possibility of origination of trade mark protection is equally listed next to the two other possibilities, registration ( $\S 4 \mathrm{Nr} .1$ MarkenG) and notoriety/well-known marks (§ 4 Nr. 3 MarkenG).

761 In German: Benutzungsmarke.

762 Marx, Deutsches, europäisches und internationales Markenrecht, at no. 584.

763 Hasselblatt/Raab, § 36 no. 71. 
There exists no fixed threshold determining when a sign has reached enough high profile to achieve protection as a use mark. Rather, this depends on the facts of each case. To that effect, the BGH constantly accepts sufficient recognition in case a non-irrelevant part of the involved audiences perceives the sign as an indication of origin. ${ }^{764}$ In general, however, sufficient high profile of signs with average distinctive power can be accepted at a degree of $20-25 \%{ }^{765}$ This percentage will have to rise with declining distinctive power of the sign at issue.

A trade mark acquired through use may not be confused with distinctiveness acquired through use. Even though both terms deal with origin of trade mark protection as a result of increased publicity, distinctiveness through use only plays a role in the course of prosecution of trade mark registrations, where missing distinctiveness can be overcome in case the respective sign has acquired a distinctive character over time by means of its use in trade or commerce.

\subsubsection{Relation to Brand Value}

In analogy to registered trade marks, the value-related factor here is whether the respective sign has accrued trade mark protection as a use mark or as a well-known mark respectively. The effort to determine this will, in general, be considerably higher than with respect to registered marks, as no official trade mark office document proving trade mark protection can be relied upon. Building a trade mark without registration is generally considerably more costly than obtaining a registration, as substantial assets need to be invested into marketing, communication, distribution etc. Such cost, as well as the cost for determining whether the sign in question has developed sufficient high profile, e.g. by means of market research, will have to enter the value computation as value detractors.

Hence, protection as a registered trade mark is usually preferable (even though cost for marketing, distribution etc. also accrue regarding goods and services marked with a registered trade mark). Proprietors tend to only rely on protection outside of the trade mark register in case they have missed to apply for a registration or in case there exists use leading to protection as a

764 BGH, decision of September 4, 2003 - I ZR 23/01 - Farbmarkenverletzung I.

765 Ströbele/Hacker, Markengesetz, § 4 no. 37. 
well-known or as a use mark which entails a more favourable priority than a registered mark would do. ${ }^{766}$

\subsection{Use}

\subsubsection{The Law in General}

In Europe, the proprietor has the obligation to use the trade mark in trade or commerce within five years after registration. Additionally, he may not suspend the use of the trade mark at any time during its lifetime for an uninterrupted period of five years or more, unless there are proper reasons for doing so. ${ }^{767}$ In case of failure to use the trade mark as described, the mark does not instantly become invalid. However, once the proprietor legally enforces it vis-à-vis others, these persons may hold the lack of use against him. ${ }^{768}$ In addition, any natural or legal person may submit an application for revocation to OHIM, Artt. 55(1)(a) and 50(1)(a) CTMR.

Correct use must be "genuine" as opposed to a mere pseudo- or token use. This means that the proprietor is obliged to utilise the trade mark on the market with its product- or service-related functions and not merely in order to maintain the mark. ${ }^{769}$

\subsubsection{Findings - Relation to Brand Value}

Like registration, correct trade mark use is a yes or no issue. Failing use after lapse of the grace period or for any period of more than five years during the lifetime of the trade mark does not automatically render the mark invalid yet jeopardises it. Hence, it must be assessed in a given case whether others have already taken action against the mark. In this context, again, the negative side has stronger adverse effects on brand value than the positive side (correct use) has beneficial ones. Affirmed genuine trade mark use is no more than an enabler for brand value generation.

766 Marx, Deutsches,europäisches und internationales Markenrecht, at no. 385.

767 Art. 15 CTMR.

768 Art. 43(2) CTMR; Art. 56(2) CTMR; Artt. 95(3) and 92(a) and (c) CTMR; Artt. 50(1)(a), 95(1) CTMR.

769 Marx, Deutsches, europäisches und internationales Markenrecht, at no. 1348. 


\subsection{Title}

\subsubsection{Introductory Remarks}

The allocation of the trade mark to a specific proprietor puts it at his disposal - exclusively or non-exclusively, depending on the type of title. ${ }^{770}$ In the majority of all cases, trade mark title exists in the form of single or joint ownership or exclusive or non-exclusive licensee status.

In terms of legal enforceability of the mark, it is important to make sure the trade mark is registered in the correct (natural or legal) person's name. However, the question whether the owner is the 'right' one in a marketing sense is a business strategic rather than a legal issue. ${ }^{771}$

\subsubsection{Relation to Brand Value}

A full owner is enabled to utilise and exploit the trade mark in any form he chooses (as long as he does not violate any third party rights), be it use on goods and/or services as part of a brand, sale, licencing, securitisation, cancellation or other. A licensee's rights are more restricted, depending on the type of exclusivity and the terms of the licencing agreement. ${ }^{772}$

The higher the quality of title in a trade mark, i.e. the closer it is to full ownership, the more possibilities of utilisation and exploitation does the proprietor have. Since utilisation in trade or commerce and exploitation of the brand are prerequisites for and cornerstones of value generation, full trade mark title is more beneficial than restricted title.

On the other hand, need and willingness to value a brand generally decline with the quality of title. Some situations requiring brand valuation only apply to full owners, such as most brand transactions. Nonetheless, as it cannot be prima facie ruled out that licensees in rare cases also need to value the respective brand, it should be examined within the legal dimension of the SIM whether the type of trade mark title is sufficient in light of the mark's (intended) use.

770 Cf. Artt. 16 et seq. CTMR.

771 Therefore, it needs to be assessed in the course of the business strategic dimension whether the proprietor is in a position to exploit the asset in a best possible way.

772 More on licencing infra at 5.13.1. 


\subsection{Prosecution, Litigation and Settlement}

\subsubsection{Introductory Remarks}

In many cases, trade marks are challenged and not registered in the first place or eventually cancelled after registration. ${ }^{773}$ Hence, opposition, cancellation and appeal proceedings before OHIM, litigation before the CFI and ECJ and before the Community trade mark courts and other national courts play a key role and can be crucial stumbling blocks on the road to a well established and valuable brand.

The possibility of legal enforcement, if actively used, prevents others from using the trade mark in question or confusingly similar marks which undermine the functions and reputation of the said mark. Without this possibility to ensure the mark's exclusivity against possible third party violations, the value of a mark and therewith of the corresponding brand would be constantly at risk and therefore instable.

\subsubsection{Relation to Brand Value}

The prosecution and litigation status of a trade mark directly correlates with its existence, legal strength and associated cost and therefore also with the respective brand's value (potential). As seen above, ${ }^{774}$ even a trade mark application offers a value. However, as a general rule, the more stages of prosecution and possible litigation have been passed successfully, the more certain it becomes that the trade mark will be registered as desired or be upheld respectively. Hence, it needs to be assessed whether all prosecution stages have been completed or, if not, how likely their successful completion is. Furthermore, litigation risk needs to be determined (as this is a cost factor) as well as the likelihood of success or failure in this regard (this is not just a cost factor but also an issue of existence of legal protection and therefore of freedom to operate the brand as desired). Such assessment cannot be carried out without feedback to the findings of other legal issues such as likelihood of confusion or possible dilution of a mark with a reputation in the Community.

773 For instance, OHIM received 16,468 and closed 12,208 oppositions (4,426 thereof by decision) in the year 2007, cf. Office for Harmonization in the Internal Market (Trade Marks and Designs) (OHIM), Statistics of Community Trade Marks 2007, p. 5.

774 At 5.1, fn. 626 . 
Options for settlement may also play an important role, as settlement is a time and cost saver ${ }^{775}$ and the less cost needs to be subtracted from (potential) revenue streams derived from the brand the better. ${ }^{776}$

However, building a reputation for toughness in opposition cases can help reduce trade mark maintenance cost, of which prosecution and litigation cost is part. An economic study has found that "brand owners can benefit from a reputation for tough opposition to trade mark applications", as "such a reputation induces applicants to settle trade mark opposition cases more readily". ${ }^{777}$ Hence, it can be worthwhile to determine whether the proprietor has built such a reputation.

\subsection{Likelihood of Confusion}

\subsubsection{The Law in General}

Likelihood of confusion is the major ground for invalidity of a registered trade mark arising from other proprietors' rights. ${ }^{778}$ It is therefore not being examined ex officio by OHIM in the registration procedure but belongs to the so-called 'relative grounds for refusal' of trade mark protection which can be raised by third parties during opposition as the earliest possible point in

775 Between 1996 and 2004, Community trade mark opposition cases settled by the parties were closed on average after three years whereas those cases adjudicated by OHIM took more than four years, cf. von Graevenitz, Which Reputations Does a Brand Owner Need? Evidence from Trade Mark Opposition, pp. 3, 5 .

776 Of the 12,208 OHIM opposition cases closed in 2007, 7,782 were closed without judgment - most likely by settlement. Cf. Office for Harmonization in the Internal Market (Trade Marks and Designs) (OHIM), Statistics of Community Trade Marks 2007, p. 5.

777 von Graevenitz, Which Reputations Does a Brand Owner Need? Evidence from Trade Mark Opposition, p. 1.

778 Other such relative grounds for refusal of protection include, for example, double identity, Artt. 8(1)(a), 9(1)(a) CTMR, and the dilution, damage and misappropriation caases concerning marks with a reputation in the Community, Artt. 8(5), 9(1)(c) CTMR. In the case of double identity, that is identity of the mark for which registration is sought with an earlier mark and of the respective goods and services classes, the older mark is protected without further requirements which have to be met. However, double identity cases are rare in practice compared to cases of similarity, for which likelihood of confusion must be proven in order to establish trade mark violation. Double identity will therefore not be further discussed hereafter. Likelihood of confusion shall be the only relative ground for refusal covered in detail in this work due to its outstanding practical significance. In the course of practical application of the SIM, other relative grounds for refusal may have to be included in the legal dimension. 
time.

Contrary to double identity cases, in which a violation can be established without having to meet any further requirements, likelihood of confusion on the part of the public must be proven in case the conflicting mark is identical with or similar to the earlier trade mark and the goods or services covered by the marks are identical or similar, Artt. 8(1)(b), 9(1)(b) CTMR. Such a risk of confusion includes the risk of association with the earlier trade mark. ${ }^{779}$

Having to prove likelihood of confusion is reasonable, as the proprietor of a a younger mark which does not exactly match the older sign or of a younger mark being identical to the older one but (sought to be) registered for different goods or services shall have freedom to operate unless the older mark is harmed in its main function, ${ }^{780}$ the origin function. Therefore, likelihood of confusion must be understood in light of the origin function as the risk that the relevant public might believe the goods or services in question come from the same undertaking or, if applicable, from economically linked undertakings. ${ }^{781}$

Likelihood of confusion on the part of the public must be appreciated globally, taking into account all factors significant to the circumstances of the case. ${ }^{782}$ As Recital seven CTMR explains, assessment of risk of confusion depends on numerous elements, in particular "the recognition of the trade mark on the market, the association which can be made with the used or registered sign, the degree of similarity between the trade mark and the sign and between the goods or services identified". This global assessment implies some interdependence between the relevant factors and, in particular, the similarity of the trade marks and the similarity of the goods or services identified. Accordingly, a lesser degree of similarity between these goods or services may be offset by a greater degree of similarity between the marks, and vice versa. ${ }^{783}$

779 Such likelihood of association is existent if the relevant public assume that the goods or services marked with the similar sign is of the same commercial origin - not because they confuse the signs but because they deem the differences between the signs immaterial, cf. Fezer, $\S 14$ no. 136 et seq.

780 Cf. Recital seven CTMR: "... a Community trade mark, the function of which is in particular to guarantee the trade mark as an indication of origin ...".

781 ECJ, above fn. 125 - Canon, para. 29 and above fn. 644 - Lloyd Schuhfabrik Meyer, para. 17.

782 Cf. e.g. ECJ, judgment of 11 November 1997, Case C-251/95, [1997] ECR I-6191, SABEL BV v. Puma AG, Rudolf Dassler Sport - SABEL, para. 22; above fn. $125-$ Canon, para. 16; above fn. 644 - Lloyd Schuhfabrik Meyer, para. 18. 
The assessment of likelihood of confusion must, as far as concerns the visual, aural or conceptual similarity of the marks in question, be based on the overall impression given by the marks, particularly bearing in mind their distinctive and dominant components. ${ }^{784}$ Thereby, the degree of visual, aural or conceptual similarity must be determined as well as, where appropriate, the importance of these factors in light of the category of goods or services in question and the circumstances in which they are marketed. ${ }^{785}$

In this global appreciation of likelihood of confusion, the perception of the marks by the average consumer of the goods or services in question plays a decisive role. The average consumer normally perceives a mark as a whole and does not analyse its various details. ${ }^{786}$

The criterion of likelihood of confusion determines whether the minimum space between two marks, a prerequisite for their coexistence, is undercut or maintained. As a concept of law, it may not be proven empirically but purely normatively. The stronger the distinctive power of the earlier mark, the greater will be the risk of confusion. ${ }^{787}$ Hence, marks which are highly distinctive, either per se or due to their reputation in the public, enjoy a broader scope of protection than marks which are of less distinctive character (irrespective of whether the relevant public actually confuse the conflicting signs).

\subsubsection{Findings - Relation to Brand Value}

Existing likelihood of confusion, invoked by a third party, vitiates the registration of the infringing mark. In most cases, especially if the corresponding brand is still juvenile, ${ }^{788}$ this has desastrous consequences for the utility and therewith the value of the brand, as legal (trade mark) freedom to operate ceases to exist.

Hence, risk of confusion, whether it is high, average, low or nonexistent,

783 ECJ, Canon, above fn. 125, para. 17; Lloyd Schuhfabrik Meyer, above fn. 644, at no. 19.

784 CFI, judgment of 15 March 2006, Case T-35/04, [2006] ECR II-785, Athinaiki Oikogeniaki Artopoiia AVEE v. Office for Harmonisation in the Internal Market (Trade Marks and Designs) (OHIM) - FERRO, para. 45.

785 Lloyd Schuhfabrik Meyer, above fn. 644, para. 27.

786 ECJ in SABEL (fn. 782) para. 23 and Lloyd Schuhfabrik Meyer (fn. 644) para. 25.

787 ECJ, above fn. 782 - SABEL, at para. 24.

788 Cf. 5.1. 
must be assessed in the course of every examination of legal brand value influencers. As a question of law, it needs to be examined on a case by case basis. There is no predefined relation between the degree of likelihood of confusion pertaining to the trade mark in question and brand value. Having a fixed team assess the legal dimension therefore builds valuable experience and brings about maximum reliability of results.

In order to prevent overlap of different points assessed within the legal dimension of the SIM, the question whether and how likelihood of confusion has actually been invoked against the proprietor of the brand under valuation, i.e. the issue of prosecution and litigation status, must be dealt with as a separate item (cf. 5.10).

\subsection{Protection Beyond Similarity:}

\section{Marks With a Reputation and}

\section{Well-Known Marks}

\subsubsection{Introduction}

As mentioned above, likelihood of confusion shall be the major relative ground for refusal of trade mark protection this work is dealing with (cf. fn. 778). However, in order to look into their implications on trade mark and therefore on brand value, the relative grounds for refusal of trade mark protection dealing with unfair advantage and detriment of registered trade marks and of well-known marks shall be briefly dealt with in the following.

\subsubsection{Trade Marks With a Reputation}

Pursuant to Art. 8(5) CTMR, ${ }^{789}$ a trade mark applied for is not to be registered if it is identical with or similar to an earlier mark but its goods/service classes are not identical or similar to the goods/services for which the earlier

789 Cf. the parallel provisions in Art. 4(3) and Art. 4(4)(a) CTMD. The wording of these provisions and Art. 8(5) CTMR is similar to Art. 9(1)(c) CTMR and Art. 5(2) CTMD, the slight difference resulting from the fact that the former provisions deal with registrability whereas prohibition of use of a registered mark is at issue in the case of the latter provisions. In the following, protection of trade marks with a reputation absent likelihood of confusion shall be illustrated on the basis of Art. 8(5) CTMR only. 
mark is registered, in case the earlier mark has a reputation" 790 and "the use without due cause of the trade mark applied for would take unfair advantage of, or be detrimental to, the distinctive character or the repute of the earlier trade mark" ${ }^{791}$ This provision protects registered trade marks with a reputation, in certain circumstances, against abuse of their unique drawing power, even if the goods and/or service classes the conflicting signs relate to are neither identical nor similar and there exists no likelihood of confusion. It transfers the abovementioned ${ }^{792}$ principle laid down in Art. 16(3) TRIPs to the European level. ${ }^{793}$

Next to the requirement of identity or similarity of the marks in question, Art. 8(5) CTMR provides that the older mark must have a reputation, either in the European Community in the case of a Community trade mark or in a Member State in case of a national mark. The CTMR does neither stipulate what 'reputation' in this sense means nor whether 'reputation' differs from the term 'well-known' as laid down in Art. $6^{\text {bis }}$ Paris Convention. The European Courts have developed a case law definition for 'reputation' yet it remains unclear whether there is a difference between the two terms. For instance, the ECJ held in General Motors v Yplon ${ }^{794}$ that a trade mark must be known by a significant part of the public concerned in a substantial part of the relevant territory in order to have a reputation. Furthermore, in the course of assessing the issue of reputation, it was held that one should take into account the intensity, geographical extent and duration of the mark's use, its market share and the size of the investment made in promoting it. It was argued in this case that a mark did not have to be well-known in the sense of the above-mentioned Paris Convention provisions in order to have a reputation. ${ }^{795}$ However, the ECJ did not comment on this issue.

Hence, quantitatively, a certain level of publicity is necessary for a trade mark

790 A reputation in the Community in case of a CTM and a reputation in a Member State in case of a national trade mark.

791 Similarly, § 9(1) Nr. 3 MarkenG stipulates the same with respect to German trade marks or trade mark applications respectively.

792 Cf. above at fn. 757.

793 In contrast, the issue of enforceability of unregistered well-known trade marks is left for the Member States as EU legislation does not address the requirement of Art. $6^{\text {bis }}$

Paris Convention to allow a well-known unregistered mark to be asserted against the use of a younger mark.

794 Judgment of 14 September 1999, Case C-375/97, [1999] ECR I-5421, General Motors Corporation v. Yplon SA.

795 Ibid. at para. 13. 
to have a reputation within the public concerned. Whether the relevant part of the public consists of the public at large or a specific part thereof depends on the type of marked goods/services. In the light of the criteria mentioned in the preceding paragraph, assessment on a case-by-case basis is necessary while the law does not require certain percentage levels. ${ }^{796}$ However, as a practical rule of thumb, one can say that a degree of awareness within the relevant audiences of approximately $40-50 \%$ and higher should suffice. ${ }^{797}$

As to the abovementioned requirements of unfair advantage or detriment to the distinctive character or the repute of the earlier mark, Advocate General Jacobs observed in Adidas-Salomon v Fitnessworld Trading ${ }^{798}$ that the taking of unfair advantage concerns free-riding where the defendant is using its mark to trade on the reputation of another. Detriment to the distinctive character of a trade mark - this reflects what is generally referred to as dilution - is existent where the use of the defendant's mark is likely to blur the distinctiveness of the older mark so that it is "no longer capable of arousing immediate association with the goods for which it is registered and used". ${ }^{799}$ Detriment to the reputation of a mark, also referred to as tarnishment, occurs where the association between the infringing sign and the registered mark can damage the reputation of the latter in such way that its power of attraction is reduced.

The detriment Art. 8(5) CTMR seeks to protect the reputable mark of results from a certain degree of similarity between the signs in question causing the audience to establish a connection between them without confusing them. Hence, absent the prerequisite of likelihood of confusion, there exists the unwritten requirement of a link to the reputable mark in the minds of the relevant audience, created by the use of the junior mark. ${ }^{800}$ Whether or not

796 Cf. e.g. CFI, judgment of 6 February 2007, Case T-477/04, [2007] ECR II-399, Aktieselskabet af 21 . November $2001 \mathrm{v}$. Office of Harmonization for the Internal Market (Trade Marks and Designs) (OHIM) - TDK, at para. 49.

797 Hasselblatt/Hasselblatt, $\S 38$ at no. 123.

798 Opinion of Mr Advocate General Jacobs delivered on 10 July 2003, Case C-408/01, [2003] ECR I-12537, Adidas-Salomon AG and Adidas Benelux BV v Fitnessworld Trading Ltd.

799 Ibid. at para. 37.

800 Cf e.g. ECJ, judgment of 23 October 2003, Case C-408/01, [2003] ECR I-12537, Adidas-Salomon AG and Adidas Benelux BV v. Fitnessworld Trading Ltd - AdidasSalomon v Fitnessworld Trading and CFI, judgment of 25 May 2005, Case T-67/04, [2005] ECR II-1825 Spa Monopole, compagnie fermière de Spa SA/NV v. Office of Harmonization for the Internal Market (Trade Marks and Designs) (OHIM) - SPAFINDERS. This requirement is roughly equivalent to the requirement of Art. 16(3) 
such a link exsists must be assessed on the basis of all relevant facts of the specific case yet it is, for instance, not sufficient that the defendant's sign is perceived merely as an ornament. 801

\subsubsection{Well-Known Marks}

As seen above, the Community trade mark system does not include rules regarding well-known marks within the meaning of Art. $6^{\text {bis }}$ Paris Convention per se. ${ }^{802}$ However, various national laws afford protection to well-known marks, for instance the German MarkenG. In this light, § 10(1) MarkenG stipulates that a trade mark may not be registered in case it is identical with or similar to an older mark which is well-known domestically pursuant to Art. $6^{\text {bis }}$ Paris Convention and the requirements of $\S 9(1)$ Nr. 1 (double identity), Nr. 2 (likelihood of confusion) or Nr. 3 MarkenG (protection against unfair advantage and detriment) are met. Hence, amongst others, all that has just been said with respect to protection of trade marks with a reputation from unfair advantage and detriment (§ 9(1) Nr.3 MarkenG) applies accordingly to well-known marks, transferred to the national German level.

\subsubsection{Implications on Brand Value}

As shown above, a trade mark must have reached a relatively high level of awareness within the relevant audience in order to have a reputation under Art. 8(5) CTMR. This cannot be reached without substantial marketing skill and investment, creating significant goodwill around the registered sign. Brand awareness is a basic prerequisite for the formation of brand image. ${ }^{803}$ Brand image, in turn, steers buyer behaviour ${ }^{804}$ and is therefore a crucial factor influencing income streams resulting from the brand. Hence, over-average levels of brand awareness secure comparatively high and steady income streams.

The brand component the awareness of which is measured is the device or

TRIPs that the use of the younger mark should "indicate a connection" to the proprietor of the well-known mark.

801 ECJ, above fn. 800 - Adidas-Salomon v Fitnessworld Trading, at para.s 30 and 40.

802 Cf. e.g. supra at 5.7.1.

803 Cf. supra at 2.1.2.2.1.

804 Ibid. 
brand achievement respectively, e.g. logos, packaging shapes, designs, smells etc. - signs some of which may be protectable as trade marks. ${ }^{805}$ Therefore, in general, brands the trade mark part of which has become strong enough to have a reputation subject to Art. 8(5) CTMR are more valuable than those which do not show this characteristic. The same applies with respect to well-known marks. This reflects the fact that trade mark law is essentially part of competition law seeking to protect the trade value (i.e. the brand) around the trade mark. ${ }^{806}$

The assessment of reputation and well-known character of a trade mark includes qualitative and quantitative components. It offers as little a fixed hurdle between 'yes' and 'no' as its relation to brand value is fixed. Also, there exist differences in strength within the groups of marks with a reputation and of well-known marks.

Hence, the fact that a trade mark is well-known or has a reputation is a strong indicator of over-average value of the related brand. However, this statement is worth relatively little without analysis of the factors leading to the wellknown character or reputation respectively. These factors, e.g. brand image and market share, are no legal issues and will therefore have to be assessed in the course of one of the other three dimensions - in the case of brand image and market share, the technical dimension. Since well-known character or reputation respectively and the factors leading to these characteristics are closely related, the appraiser will have to carefully define the respective fact statements ${ }^{807}$ in order to prevent or at least minimise overlap. Also, financial investment made in order to establish the well-known character or reputation of the respective trade mark must be part of the value equation and therefore be dealt with, amongst others, in the financial dimension.

\subsection{Contractual Limitations}

Contractual agreements relating to trade marks and brands can be found relatively often in practice. The most common are licencing and delimitation or coexistence agreements. Both can have a positive or negative impact on brand value.

805 Ibid.

806 Götting, IIC 2000, 389, 390.

807 Cf. above at 4.1.2.1. 


\subsubsection{Licencing Agreements}

Licencing agreements are used to convey the right to use the respective object of licence from the proprietor or licensor to the licensee, exclusively or non-exclusively, in whole or in part. The licencor receives the right to collect royalties in return - up front payments, lump sums, running royalties or milestone payments, either individually or in combination. ${ }^{808}$ Both brands and trade marks can be licence objects. It is up to the parties to each agreement to negotiate the scope of the object of licence to their satisfaction. Ideally, this scope provides for both satisfactory remuneration for the licensor and an increased product differentiation and successful product positioning in the long term by transferring the brand image and its values on the licensee's products or services, thus enabling expedient commercial exploitation of the licence object for licensor and licensee. A number of types of licence agreements specific to the brand area such as brand and line extensions are specified above at 2.3.2.2.

There are two types of exclusive licences. Licencing agreements which are exclusive in the strict sense give the licensee an extremely strong position since he is the only person being allowed to use the mark (not even the licensor is allowed to). The licensor merely remains in a formal position as title holder in the respective mark. The second form of exclusive licence often denoted as 'sole licence' - differs from an exclusive licence in the strict sense merely in that the licensor is entitled to continue to use the object of licence. In contrast to that, under a non-exclusive licence, the licensee is one legitimate user of (potentially) many. ${ }^{809}$

Agreements of licence may provide for limitations of the use of the respective trade mark or brand to specific geographic regions, certain products or services or other. It depends on the negotiating skills of the parties and on market success whether such limitations are de facto in line with the relevant party's strategy and portfolio or turns out to be a stumbling block on the road towards a fully satisfactory exploitation of its IP and product/service portfolio. ${ }^{810}$ In order to reduce risk of failure, licensors usually contractu-

808 Cf. above at 2.3.2.2.

809 Fammler, Der Markenlizenzvertrag, p. 88.

810 For instance, Exnorm, a German producer of prefabricated houses, licenced the RTL logo (belonging to a TV station) yet the RTL houses turned out to be a flop. On the other hand, Junghans is successfully marketing LEGO watches, cf. Fischer, Geliehener 
ally ensure quality control of the respective products and/or services, which should include the right to demand samples prior to the start of production, the right to enter the licensee's or producer's premises, and other. ${ }^{811} 812$

In the course of a sale or other transfer of the licenced trade mark or brand, the existence of the licence can be an impediment for the proprietor, as it does not automatically terminate upon sale of the licenced object. ${ }^{813}$ Hence, the transferor of the respective trade mark or brand may get less in consideration than in case the trade mark or brand was not licenced. Whether this is effectively the case depends on the actual circumstances, such as the strategy of the transferee and the type of licence (exclusive or non-exclusive). It may well be that the transferee, acquiring a non-exclusively licenced brand, appreciates this already existing income stream.

This shows that it always depends on the concrete situation whether a licencing agreement - in whichever form - is beneficial or detrimental to the value of the brand in question. However, one can say that there are a number of

Ruhm.

811 Groß, Marken-Lizenzvertrag, pp. 8, 21; Fammler, Der Markenlizenzvertrag, p. 117 et seq.

812 There are situations in which this degree of control and extension of the brand does not suffice for the proprietor's purposes. He may want to make sure that the identity of the licensee completely comes second to the brand name and identity. In this case he will resort to a special form of licencing: franchising. In the course of an average franchise, the franchisor provides the franchisee with more than a right to use a certain mark or brand. For example, he provides the franchisee with physical items such as store signs and product displays. It is also common to give the franchisee access to the use of other IP rights such as designs and copyrights. All of this is necessary to reach the franchisor's purpose of tying the franchisee to his own (the franchisor's) products or services and the marketing identities built around these products or services. The benefit a franchisee derives from the franchising agreement is the ability to enter a certain market with relatively small effort in relatively short time due to the use of the franchisor's brand and corporate appearance. This will be the more financially viable the higher the recognition of the franchisor's brand is within the target audience (provided that the target audience is brand focussed at all). However, should the franchise come to an end and the franchisee decide to continue a similar business by himself, the franchise is likely to constitute a major stumbling block which will have a negative financial impact on him. There are two major rasons for this, the first of which being the fact that the former franchisee will have to carry out brand innovation, i.e. build a completely new brand, and make himself known in the market. However, this would also have been necessary if he had wanted to enter into the market before or without concluding a franchising agreement. The second reason why a terminated franchise may be detrimental is that the franchisor will have prudently made sure to insert a non-competition clause in the agreement, prohibiting the engagement of the franchisee in the same or similar business for a certain period of time after termination of the franchise. More on franchising e.g. in Dvorak, Der Lizenzvertrag im Franchising and Flohr, Franchisevertrag.

813 Binder, Lizenzierung von Marken, p. 534. 
crucial factors to be taken into account. These are the degree of exclusivity of the licence, size of licence-based revenue streams (royalties) and scope and object of licence and their inter-relation with the parties' respective business strategies.

\subsubsection{Delimitation or Coexistence Agreements}

Coexistence or delimitation agreements ${ }^{814}$ serve the purpose of resolving present and preventing future conflicts by clarifying the practical application of two or more conflicting trade marks. ${ }^{815}$ Instead of solving the conflict in court, the parties have chosen the alternative of saving cost and time, giving up part of their initially envisaged trade mark scope and receiving legal certainty in return. This shows that such agreements cannot function without a - at least to some extent - positive attitute of all parties towards each other and each other's trade mark rights. Such attitude is likely to be fostered by the fact that a Community trade mark application can founder on just one conflicting national mark, Art. 42 CTMR.

Delimitation agreements typically stipulate that the younger mark may only be registered and used for a limited number of goods and/or services and that no rights arising from it may be enforced against the proprietor of the prior mark. In return, the latter tolerates the registration and use of the younger mark and withdraws a potentially filed opposition. ${ }^{816}$

The ECJ has recognised delimitation agreements as admissible and advantageous, provided they merely serve the purpose of avoiding confusion and conflicts and do not intend market allocation or other restraints of competition. ${ }^{817}$

Such contracts are of considerable practical significance. Experience has shown that in the case of approximately half of all German applications a delimitation agreement will be concluded at some stage. ${ }^{818}$ Of the 12,208 closed opposition cases before OHIM, 7,782 were settled without an Office decision $^{819}$ and likely by delimitation agreement. The two-month cooling-off

814 Cf. Art. 43(4) CTMR.

815 Degen, Die Bewertung von Marken aus rechtlicher Sicht, p. 112.

816 Harte-Bavendamm/von Bomhard, GRUR 1998, 530, 530.

817 ECJ, judgment of 30 January 1985, Case 35/83, [1985] ECR 363, BAT CigarettenFabriken GmbH v. Commission of the European Communities - Toltecs/Dorcet II.

818 Harte-Bavendamm/von Bomhard, GRUR 1998, 530, 531. 
period after filing of the opposition and prior to the contradictory phase ${ }^{820}$ is conducive to this circumstance.

Delimitation agreements can have a positive impact on brand value if they resolve existing or impending conflicts which jeopardise the existence of the trade marks in question. Therefore, they help ensure the legal side of brandrelated freedom to operate. Furthermore, they significantly help reduce cost, which would be a brand value detractor.

\subsubsection{Findings - Relation to Brand Value}

A licencing agreement can be conducive or detrimental to brand value, depending on its content, mode of execution, market success and the perspective from which the brand is being valued (this will usually be the proprietor, not the licensee). The amount of royalties paid and due adds to brand value. In general, the amount of royalties rises with the degree of exclusivity. Whether or not the proprietor has chosen to convey the appropriate degree of exclusivity to the licensee (thereby enhancing his brand's market penetration and publicity and thus its value) must be assessed in each individual case. This shows that it would be precarious to merely look at the monetary side in order to assess whether a specific IP licencing contract adds to the value of the IP right: an exclusive licence (in the strict sense) may create a substantial royalty stream for the licensor but at the same time impose a deadlock on his side which prevents him from exploiting the licenced right in a beneficial way himself, particularly if the licensee defaults and the licence agreement does not specify that the exclusivity turns into non-exclusivity in this case.

Contracts of licence have a positive impact on brand value if they enable a proliferation of the trade mark and brand in a way which the licensor would not be able to. A symbiosis of licensor and licensee in this sense could for instance be conducive if the licensee has access to distribution channels different from those of the licensor, and complementing them in a useful way.

A negative impact of a brand licencing contract on the asset's value can

819 Office for Harmonization in the Internal Market (Trade Marks and Designs) (OHIM), Statistics of Community Trade Marks 2007, p. 5.

820 Rule 18(1) Commission Regulation (EC) No 2868/95 of 13 December 1995 implementing Council Regulation (EC) No 40/94 on the Community trade mark, OJ L 303, 15.12 .1995$, p. 1 . If the parties close the opposition proceedings during the cooling-off period, OHIM takes no decision on costs, Rule 18(4) of the same Regulation. 
occur in cases in which the contract is concluded to the effect that it does not leave enough room for brand building and development. For example, an exclusive licencing agreement regarding a combination mark for clothing with ten years of duration may hinder the licensor from developing an online marketing strategy if this has not been foreseen and provided for in the contract itself. Furthermore, every licensor needs to carefully deal with the issue of quality in order to prevent the goods or services marked with the licenced brand to fall behind the quality the licensor envisages or provided before he licenced out the brand, as product and/or service quality problems can substantially damage the value of the brand. Therefore, quality standard clauses can be found commonly in licencing contracts. ${ }^{821}$

Hence, the valuator must assess both quantitative and qualitative licencingrelated brand value influencers - expected and factual royalty income streams as well as the abovementioned strategic factors. Licencing-related value factors can only "make or break" brand equity in extreme situations such as the deadlock in case of an exclusive licence and default of the licensee mentioned above. In general, they affect brand value on a sliding scale which must be assessed by an expert on a case-by-case basis.

As delimitation agreements are highly important in practice, it should be assessed within the legal dimension whether conclusion of such an agreement is expedient and has been or is expected to be made. Such contracts generally increase brand value, since they are considerable time and cost savers.

\subsection{Trade Mark Surveillance and Genericide Prevention}

As well as a pre-registration search is necessary in order to prevent collision and secure one's own lawful trade mark space, post-registration monitoring is essential in light of the same purposes. ${ }^{822}$ Ideally, any trade mark proprietor should observe others' possibly infringing activities in the area of identical and/or similar signs, goods and/or services in order to be able to take appropriate legal action as early as possible. Potential infringement needs to be

821 Cf. Fammler, Der Markenlizenzvertrag, p.117 et seq.; Groß, Marken-Lizenzvertrag, pp. 8, 21.

822 This has become particularly important in the on-line world where trade mark infringement is rampant, be it on websites, in blogs, videos, through ad words, meta tags, in virtual worlds such as Second Life, or other. 
detected and taken action against in order to prevent dilution of the respective marks which would impend if the proprietor tolerated conflicting marks on the market. Such tolerance would limit the distinctiveness of his marks and therefore their scope of protection. The impact on brand value would be correspondingly negative.

Furthermore, in order to prevent genericide, ${ }^{823}$ the proprietor may be well advised to make sure that (he and) others always identify the respective trade mark(s) as such. Hence, a registered trade mark should always come with the $(\mathrm{R})$ sign, an unregistered trade mark should be earmarked with a ${ }^{\mathrm{TM}}$ and a service mark with a ${ }^{5 M}$. In addition, it is advisable to constantly use the trade mark followed by the generic or dictionary name, e.g. "This Apple computer's latest features ..." instead of "This Apple's latest features ...".

Hence, the brand appraiser needs to assess whether the proprietor business has installed pre- and post-registration trade mark surveillance and genericide prevention schemes in order to ensure that the respective trade mark is neither infringing nor being infringed or at risk of becoming generic.

Such schemes do not only safeguard the legal trade mark freedom to operate of the respective brand(s). If applied consistently, the proprietor could save money in the long term by building a reputation of being a tough counterpart in prosecution and litigation, leading to a comparatively high quota of settlements (which helps avoid costly and lengthy litigation ${ }^{824}$ ). ${ }^{825}$

Hence, trade mark surveillance (coupled with according action ${ }^{826}$ ) and genericide prevention, if properly implemented, safeguard and enhance brand value. These items - unlike, for instance, proper trade mark registration - are no points which can 'make or break' brand value. Rather, they influence brand value to the positive if they exist and to the negative if they do not - both on a sliding scale which must be assessed on a case-by-case basis.

823 Former trade marks which are now generic include escalator, thermos, cellophane and kerosene, cf. Murphy, Brand Strategy, p. 138.

824 Cf. above at 5.10.2.

825 von Graevenitz, Which Reputations Does a Brand Owner Need? Evidence From Trade Mark Opposition, p. 1.

826 Otherwise, that is if the proprietor refrains from taking legal action despite his knowledge of a conflicting younger mark, his rights may be subject to forfeiture after a certain time span of acquiescence, cf. Art. 53 CTMR. 


\subsection{Summary}

Even though legal issues might not be in the center of attention in the field of brand valuation, they are crucial in two aspects: firstly, trade mark protection provides legal scarcity, which is, in general, the foundation of the respective asset's value potential. Secondly, there are a number of such issues which constitute important value influencers, such as concrete distinctiveness, graphic representability, title, prosecution and litigation status of the mark and likelihood of confusion. Hence, if one wishes to achieve comprehensive brand valuation, one cannot afford to ignore trade mark protection matters.

While most points are amenable to rules of thumb, such as the more territories a trade mark is registered for the better, there cannot exist a pre-defined relationship between the degree of compliance with the respective legal issue and brand value. This connection is qualitative and contextual, which means it must be assessed on a case-by-case basis. ${ }^{827}$ However, one can distinguish legal issues which can "make or break" brand value, such as trade mark registration, and those items which influence brand value on a sliding scale, such as the licencing status of the brand under valuation.

Although all important legal issues pertaining to brand value (and some beyond that) have been dealt with, this list is not exhaustive. It may be necessary in practice to add new issues, such as more relative grounds for refusal of trade mark protection or the existence of liens and other use- and exploitation rights, or to substitute existing points with one of these. The SIM can thus be flexibly adapted to new or changed circumstances. ${ }^{828}$

827 The SIM has been designed to remove subjectitvity out of this assessment process as much as possible by stipulating that a continual team of experts shall assess the four dimensions of value. This builds an unbeatable degree of experience and reliability, cf. above at 4.1.2.1.

828 Cf. 4.1.2.1 and 4.2.1.4. 


\section{Chapter 6}

\section{Summary and Perspectives}

Intellectual property per se is a legal concept. However, legal protection of inventions or other products of the mind is not an end in itself. It usually serves one or several commercial purposes,${ }^{829}$ as IP rights are, for the most part, situated in a certain business context. Hence, IP does not merely constitute rights but rather assets which, in turn, need to be properly managed.

In this context, there are a number of strategic, future-related commercial activities which cannot be properly carried out without valuation of the asset in question. They include strategic and operative IP management and controlling, IP transactions and IP finance.

These valuation scenarios were grouped together as they have in common that future value needs to be estimated on the basis of presently available data. Hence, such valuation can by definition not be accurate but must result in a value spread instead of a fixed amount. Therefore, a differentiation between so-called 'forecasting' and 'reporting' valuation was carried out in order to work out and clarify the fundamental differences between these two groups of valuations. Reporting valuations, that is mainly past-related, documentation and compliance valuation scenarios, such as assessment of damages, accounting and tax, constitute a group separate and distinct from strategic, or forecasting, valuations which this work is concerned with.

One of the main foci of this work was put on the insight that thorough under-

829 As seen from the point of view of the proprietor, which is the focus of the work at hand. From a macroeconomic perspective, intellectual property protection serves other purposes such as rewarding originators and providing incentives for innovation and disclosure of information, thus ideally increasing welfare. 
standing of intellectual property value and valuation demands examination of constitutive issues prior to dealing with details, working from general to specific. ${ }^{830}$ Thus, the logical starting point of the IP value and valuation discussion was the elaboration of the fundamental framework affecting the value of any asset, tangible and intangible. It consists of the three factors scarcity, utility and title, of which every asset possesses a certain quantum. Generally speaking, the value of an asset rises with increasing scarcity, utility and strength of title. All these factors, therefore, need to be taken into account by any proper valuation technique. For instance, the Systematic Integrated Methodology deals with the issue of title in the legal dimension. As opposed to tangible assets, scarcity of intellectual property assets is usually created by the respective legal protection regimes, as such assets are almost impossible to be controlled factually. Hence, such assets are characterised by legal and not by factual scarcity (notwithstanding the option of secrecy). Therefore, the strength of the particular legal protection must be processed by every IP valuation technique.

More on the 'how' of valuation was discussed in chapters one (requirements a forecasting valuation technique must meet), three (the state of the art of brand valuation) and four (introduction of the Systematic Integrated Methodology). At first, it was elaborated that forecasting valuation instruments shall meet the requirements of conceptual and methodical soundness, widespread acceptance and manageable output. These requirements were later utilised to scrutinise both currently applied brand valuation techniques as well as the newly introduced SIM.

As no valuation can be properly executed without at least fundamental comprehension of the nature of the valuation object, this 'what' of valuation was addressed in chapter two. It is essential to realise that all IP assets feature certain value-related characteristics due to the fact that they are intangibles. These intangible-specific value drivers and detractors include network effects, nonrivalry, scalability, nontradability, partial excludability and spillovers as well as inherent risk.

With specific respect to trade marks and brands, it was found that, while

830 This may at first glance sound trivial yet such modus operandi is essential for a thorough and successful treatment of any complex issue. However, the author has experienced that it is all too often neglected with regard to value and valuation, which entails subsequent errors such as mere fragmentariness of the respective valuation technique. 
both are intangibles, a clear-cut differentiation must be made as only trade marks belong to the group of intellectual property. Trade marks, as legal phenomena, serve the functions of signalling origin and differentiation. Trade marks which are being used in trade or commerce are always accompanied by marketing means combined with which they constitute brands.

Brands, in turn, can be defined as bundles of specific benefits which ensure that they - from the point of view of relevant target audiences - strongly differentiate from other such bundles meeting the same needs. They create communication channels between originator and target audience. A strong brand's main function is risk reduction. For instance, it enables the offeror to demand price premia as buyer behaviour is less volatile than in the case of a weak brand. This lowers the proprietor's sales and earnings risks, which leads to other positive effects such as comparatively good ratings and low cost of capital. From the customers' point of view, a strong brand, amongst others, significantly facilitates and accelerates the buying decision making process, which lowers transaction cost. It lowers various risks such as the risk of buying something unknown and the economic risk.

In view of other intellectual property rights, especially patents, it is important to note that well-managed brands augment benefits arising from such rights. This occurs, for instance, by marketing patented goods or goods produced utilising a patented process or by defending market share vis-à-vis competitors after patent (and possibly $\mathrm{SPC}^{831}$ ) protection have run out.

Brands are complex, personality-like phenomena featuring the interrelating components brand identity and brand image. Brand achievements, as components of brand identity, comprise the market-oriented signage some of which is protectable as trade marks. However, such trade mark protection is not a conditio sine qua non for the existence of a brand. Yet lacking trade mark protection is likely to impede the proprietor's freedom to operate in targeted markets, especially when the brand is still juvenile.

Generally speaking, value can be financial or non-monetary. However, for purposes of (amongst others) strategic forecasting valuations, it must be expressed in monetary terms. The value of a brand (or other asset) was therefore defined as the estimated quantity of financial assets for which an item changes hands "on the date of valuation between a willing buyer and a willing seller

831 Cf. fn. 423. 
in an arm's-length transaction after proper marketing wherein the parties had each acted knowledgeably, prudently, and without compulsion". ${ }^{832}$ The fact that this definition refers to an ideal market situation which will almost never be attained in practice mirrors the circumstance that forecasting valuation is not an exact art - no matter which asset, tangible or intangible, is being valued. Hence, it is crucial not to, in general, subject the valuation of intangible assets to more demanding requirements than valuation of tangible assets. Every future-related valuation is an estimate.

This shall, however, not hide the fact that trade marks and brands are, like other intangibles, considerably harder to value than most tangible assets due to their uniqueness, nonrivalry, nontradability and other factors. This makes collection of comparable market data a difficult and sometimes impossible task, which has so far made creation of sufficiently transparent intangibles markets impossible. It is therefore much harder to approximate the above definition of value with respect to valuation of an intangible asset such as a brand than in the course of valuation of most tangible assets. However, the objective of every valuation process must be the systematic and comprehensive collection of as much relevant information on the valuation object as possible.

After the fundamentals of brand and intellectual property value had thus been presented, attention was turned to the current brand valuation landscape. It was elaborated that the present state of the art of strategic or forecasting brand valuation is characterised by an implememtation gap: Even though the need for brand valuation is widely recognised, merely around $40 \%$ of all German businesses with brands value these at all. This is mainly rooted in two interrelated circumstances.

Firstly, brands and other intangibles, including intellectual property, show characteristics which make them more difficult to be valued with conventional techniques than tangible assets. This is due to the facts that there are no functioning markets for these assets (and therefore little or no reliable market data which could serve as points of reference) and that intangibles are highly contextual, i.e. dependent on other assets and the overall business strategy, in their valuation and exploitation. Furthermore, such assets are characterised by relatively high risk and cost of capital. Return on investment is highly

832 International Valuation Standards Committee, International Valuation Standards, p. 27. 
skewed. All these issues make valuation very complex.

Secondly, a major reason for abstinence from brand valuation is a perceived lack of quality of currently available valuation methodologies. The analysis of a number of such methods showed that this perception is actually justified, as there are, despite good efforts, no methods in application which meet all desired requirements. As shown earlier, the specific nature and value-related characteristics of brands and intellectual property should be comprehensively taken into account. Application of valuation methods adapted from valuation of tangible or financial assets must, alone, necessarily face serious difficulties. Even those techniques developed specifically for brands are generally not comprehensive enough.

These circumstances caused the author to develop the Systematic Integrated Methodology, or SIM, as a comprehensive brand and intellectual property valuation tool which can be deployed in any forecasting valuation setting. It is built upon lessons learned from constitutive valuation issues as well as from the analysis of the present state of the art of brand valuation.

It is, in essence, composed of a two-step process. Initially, the obligatory forecasting value spread is delimited by means of a financial income-based discounted cash flow and decision tree analysis. However, this step alone would not be able to satisfyingly reproduce the value of assets as multifaceted and complex as brands and intellectual property. Therefore, it is being complemented with the so-called 'prismatic evaluation', the unique core of the SIM.

This second step enables the valuator to process all salient contextual valueinfluencing variables in a flexible holistic way. The so-called 'four dimensions of value' - legal, technical, business strategic and financial - were conceived for this purpose. Each dimension contains a certain number of fact statements which are evaluated in a point score system by an expert in the respective field. The selection of fact statements shall follow certain rules yet provides enough flexibility for the appraiser to adapt the system to new or changed circumstances.

The legal dimension of brand value was particularly focussed on. Even though legal aspects may commonly not be treated as of central importance for valuation of brands, which are mainly marketing tools, they must be included in every diligent valuation process: Legal issues both are important for process- 
ing the fundamental value framework of scarcity, utility and title and bring about other significant value determinants such as prosecution and litigation status or likelihood of confusion.

Legal issues influence brand value in various ways. Some, such as the geographic scope of protection, affect the existence of trade mark protection as a 'yes or no' factor. Others, for instance distinctiveness or likelihood of confusion, are linked to brand value on a sliding scale.

Like all other qualitative value influencers, legal points have in common that their link to brand value is situation dependent. Even though they are susceptible to rules of thumb, there cannot exist a fixed, pre-defined mathematical relation. Hence, they must be assessed on a case-by-case basis by an expert in the field.

However, what a number of issues the negation of which leads to failing trade mark protection have in common is that such negation would be a clear brand value detractor but would not necessarily entail complete loss of utility and value of the brand. There is no automatism reducing brand value to zero in case trade mark protection of the signage at issue fails, as the marketing tool brand is able to function without trade mark protection of its devices and may already have gained enough market penetration and reputation to secure the proprietor some freedom to operate. This, in turn, may already have led to the signage being protected as trade marks on the basis of acquired distinctiveness through use or as well-known marks.

Legal factors are not always of equal importance, depending on valuation object, cause and situation. For instance, licensing agreements will only have to be examined where they are actually in existence. Hence, the respective valuation method must be flexible enough to allow for different and/or changed circumstances case-by-case.

The SIM's valuation end result is obtained by merging the point scores from the prismatic evaluation with the financial value spread. The initially obtained financial spread is narrowed considerably, resulting in a most likely value and a limited spread expressed in monetary terms. This outcome is more reliable than those obtained by means of other IP valuation methods as it expresses the value of the respective asset in a highly comprehensive yet flexible way, making sure that no important value determinant is ignored.

Since the SIM does not only provide a reliable monetary valuation result but 
also collection and analysis of salient contextual data, it can be used, next to valuation, in order to integrate the respective asset into the overall business strategy, i.e. as an evaluation tool.

Moreover, the comprehensive data collection and analysis process helps control and reduce IP-specific risks and asymmetries of information to a minimum. This means that two central factors hindering the development of workable markets for IP are considerably mitigated. Manageability and tradability of the asset in question are substantially increased.

The SIM therefore contributes to a relatively recent development which is increasingly gaining momentum: the recognition and utilisation of intellectual property as an asset class. The way IP is perceived and employed is and will be changing fundamentally.

In this connection, there are and have been endeavours to create workable markets by means of online platforms and live auctions, mainly related to patents rather than brands. ${ }^{833}$ Such projects are commendable as they make IP more visible as an asset class. A number of transactions have been successfully closed. For instance, 26 of the 78 lots offered at Ocean Tomo's first IP auction of April 2006 were sold on the floor. ${ }^{834}$

However, even though these endeavours are steps in the right direction, they have so far failed to provide large-scale, sustainable success. One of the main issues online platforms and auctions face is failure to provide sufficient contextual information. Yet information is of central importance for proper valuation of intellectual property as such assets are, as discussed above, highly unique, complex and contextual in nature. Many prospective buyers will find the risk of acquiring something unknown and/or unwanted too high, that is in case they would use the acquired IP for "active" purposes such as producing goods and rendering services. Persons could be more prone to acquisitions via online platforms and live auctions in case the sole envisaged use of the IP is blocking competitors. In such a "passive" case, comprehensive collec-

833 Such online platforms include yet2.com (http://www.yet2.com/app/about /home), Idea Trade Network (http://www.newideatrade.com/), MarkMarket (http://www.ipb.dk/en/561/buy-sell_trademarks/) and Rated Patent Exchange (https://rated-patent.com/) (all last accessed February 27, 2008). Live intellectual property auctions were, for instance, held by Ocean Tomo (http://www.oceantomo.com/auctions.html) and IP Auctions GmbH (http://www.ipauction.eu/index.htm) (both last accessed February 27, 2008).

834 Cf. sine autore (Ocean Tomo), Ocean Tomo releases results of world's first ever live patent auction. 
tion of contextual data on the asset to be acquired is much less crucial as the complex, contextual nature of an IP asset and its interdependence with other assets are more important for its due "active" use than for a mere blocking use. Moreover, in many situations such as creation of spin-offs or joint ventures, valuation of the relevant IP equals a business process rather than an on-the-spot activity. The time and expertise needed for such processes is commonly neither provided by online platforms nor by IP auctions. A flexible yet comprehensive valuation methodology such as the SIM would be considerably more suitable. 


\section{Kapitel 7}

\section{Ausführliche Zusammenfassung in deutscher Sprache}

\subsection{Einführung in die Thematik}

In heutigen global immer härter umkämpften Märkten wird eine wachsende Zahl an Produkten und Dienstleistungen zunehmend ähnlicher. Marken werden daher immer mehr zum entscheidenden Erfolgsfaktor, da sie oft das einzige den Zielgruppen eingängige Mittel zur Differenzierung darstellen. Marken spielen ebenfalls eine entscheidende Rolle in der Vermarktung von technischen Innovationen, für die entweder kein Patentschutz zu erlangen oder dieser Schutz schon abgelaufen ist, beispielsweise im Bereich der pharmazeutischen Generika. Jedoch auch für patentbasierte Produkte sind starke Marken eine wichtige Ergänzung und Möglichkeit der Stabilisierung und Stärkung des wirtschaftlichen Erfolgs, da sie zur Sicherung und Erhöhung der Rentabilität entlang der gesamten Wertschöpfungskette beitragen.

Der Strukturwandel vieler Industrienationen von einer Industriegesellschaft hin zu einer Dienstleistungs- und Hochtechnologiegesellschaft hat in den vergangenen Jahren zu einer steigenden Bedeutung immaterieller Werte geführt. Von zentraler Bedeutung sind in diesem Zusammenhang neben Arbeitskraft und Können der Mitarbeiter vor allem Patente und Marken. Laut einer Studie stieg der Anteil des Markenwerts am gesamten Unternehmenswert zwischen 1999 und 2005 von durchschnittlich ca. 56 auf ca. 67 Prozent. ${ }^{835}$ Entsprechend wichtig ist aus Sicht der befragten Führungskräfte auch eine korrekte Einschätzung des Markenwertes.

835 PricewaterhouseCoopers/GfK/Sattler/Markenverband(ed.), Praxis von Markenbewertung und Markenmanagement in deutschen Unternehmen, S. 8. 
In der unternehmerischen Praxis existieren viele Anlässe zur Bewertung geistigen Eigentums, vor allem von Patenten und Marken. Hierbei gilt es zu erkennen, dass geistiges Eigentum nicht nur rechtliche Dimensionen aufweist, sondern auch als Vermögensgegenstand behandelt, gemanagt und verwertet werden kann und sollte.

Die Bewertung geistigen Eigentums ist jedoch aufgrund ihrer interdisziplinären Natur äußerst komplex und schwierig. Nicht ohne Grund existiert eine fast unüberschaubare Vielzahl unterschiedlicher Bewertungsmethoden.

Eine Fülle an Literatur zum Thema der Bewertung geistigen Eigentums erschwert sowohl den Einstieg in die Materie als auch eine systematische intensive Auseinandersetzung mit ihr. Zum Teil wird zu früh auf besondere Probleme der Bewertung einzelner Schutzrechte eingegangen. Der erste logische Schritt sollte jedoch die Erörterung und das Verständnis grundlegender Fragen sein, die sich bei der Bewertung aller Schutzrechte (und sonstiger Vermögensgegenstände) stellen.

\subsubsection{Grundlagen der Wertbildung jedes Vermögensgegenstands}

Es ist daher wichtig zu erkennen, dass es wertbildende Faktoren gibt, die für alle gewerblichen Schutzrechte (und darüber hinaus für jeden Vermögensgegenstand) von Bedeutung sind. Grundsätzlich gilt, dass Gegenstände mit zunehmender Knappheit wertvoller werden. Kreative Ideen, Erfindungen und andere Produkte des Geistes sind jedoch, wie alle immateriellen Güter, an sich frei verfügbar und kopierbar. Abgesehen von Geheimhaltung ermöglicht erst ihr rechtlicher Schutz den Inhabern, die Verbreitung dieser Güter beziehungsweise deren Ausdruck in dinglicher Form zu kontrollieren und diese damit knapp zu halten. Deshalb ist der rechtliche Schutz eine Grundvoraussetzung der Wertbildung geistigen Eigentums.

Darüber hinaus hängt der Wert eines Vermögensgegenstandes immer von der Art der Verfügungsbefugnis über ihn und von seinem Nutzen ab. Für einen Lizenznehmer einer nichtexklusiven Markenlizenz wird beispielsweise der Wert einer Marke in aller Regel geringer sein als für den Inhaber, da er lediglich begrenzte Befugnisse hat, die Marke zu verwerten. Zudem mag eine bestimmte Marke oder ein bestimmtes Patent das Portfolio eines Unternehmens sinnvoll ergänzen und zu seiner Kernkompetenz gehören, für ein anderes Unternehmen aber nur von untergeordneter Bedeutung sein. 
Im Allgemeinen bestimmt demnach das Zusammenspiel der Faktoren Knappheit, Nutzen und Verfügungsbefugnis den Wert eines gewerblichen Schutzrechts (sowie jedes anderen Vermögensgegenstandes).

\subsection{2 'Forecasting'- und 'Reporting'-Bewertungen}

Des Weiteren wurde erarbeitet, dass ein grundlegender Unterschied zwischen zukunftsbezogenen, genannt 'forecasting', und 'reporting', bzw. vergangenheitsbezogenen, Bewertungen besteht.

Bewertungen für Zwecke der Bilanzierung oder Steuerrechnung sind zu einem gewissen Grad in ein Netz nationaler und internationaler Regularien eingebunden. Diese Regeln schreiben zum Teil die Anwendung bestimmter Bewertungsverfahren vor. Der Gutachter arbeitet in der Regel mit historischen Daten. Es ist daher auch möglich, zu einem exakt auf Euro und Cent zu berechnenden Endergebnis zu kommen. Regeln der Bilanzierung und Steuerrechnung sind eigenständig und lassen vergleichsweise wenig Raum für methodische Präferenzen bei der Bewertung. Alles in Allem sollten sie daher separat von zukunftsbezogenen Bewertungsmethoden eingeordnet werden.

Mit solch zukunftsbezogenen, oder strategischen, Bewertungen setzt sich die vorliegende Arbeit auseinander. Von zentraler Bedeutung ist hier, dass es einen einzig richtigen auf Euro und Cent zu berechnenden Wert nicht geben kann. Vielmehr resultiert jede forecasting-Bewertung in einem abgeschätzten Wertbereich. Jede zukunftsbezogene Bewertung ist per definitionem eine Prognose und Schätzung, unabhängig davon, ob man ein Auto oder ein Patent zu bewerten hat. Es kommt vor allem darauf an, wie man sowohl die Breite des Wertbereichs als auch Informationsasymmetrien und andere bewertungsbezogene Risikofaktoren minimieren kann. Dies ist bei materiellen Gütern in der Regel deutlich einfacher als bei immateriellen.

\subsubsection{Von einer forecasting-Bewertungsmethode $\mathrm{zu}$ erfüllende Vor- aussetzungen}

Dem Gedankengang folgend, dass Grundlegendes zur IP-Bewertung vor Details abzuhandeln ist, wurden zunächst die Voraussetzungen erarbeitet, welche eine ideale forecasting-Bewertungsmethode erfüllen sollte. Dies sind kon- 
zeptionelle und methodische Stichhaltigkeit, umfassende Akzeptanz sowie Handhabbarkeit der Bewertungsergebnisse.

An diesen Anforderungen wurden danach sowohl momentan angewandte Markenbewertungsmethoden als auch die selbst entwickelte Methode gemessen.

\subsection{Grundlegendes zur Markenbewertung}

Keine qualitativ hochwertige strategische Bewertung kann ohne Kenntnis der grundlegenden wertbezogenen Eigenschaften des Bewertungsobjekts durchgeführt werden. Solche Eigenschaften ergeben sich bei Marken und (anderen) gewerblichen Schutzrechten aus spezifischen Besonderheiten und aus allgemeinen Eigenschaften, die sich aus der Zugehörigkeit zur Gruppe der immateriellen Güter (auch "Intangible Assets" oder "Intangibles") ergeben.

\subsubsection{Immaterielle Güter und gewerbliche Schutzrechte}

Immaterielle Güter sind Ansprüche auf zukünftige Vorteile, welche weder physisch noch finanziell verkörpert sind. Aufgrund der veränderten globalen Wirtschaftslandschaft, welche durch zunehmendes Bewusstsein über und Nutzung von Intangibles gekennzeichnet ist, spielen diese Vermögenswerte in der heutigen Zeit eine bedeutende Rolle.

Sie weisen spezifische Besonderheiten auf, welche bei materiellen Gütern nicht oder nicht so zu finden sind. Zu diesen zählen Netzwerkeffekte, Nichtrivalität, Nichthandelbarkeit, Skalierbarkeit, partielle Ausschließbarkeit und Spillovereffekte sowie rechtliche Knappheit. All diese Eigenschaften können den jeweiligen Wert grundlegend beeinflussen, positiv wie negativ.

Jede umfassende IP-Bewertungsmethode muss diese Charakteristika berücksichtigen, da gewerbliche Schutzrechte genauso wie Brands eine Untergruppe der immateriellen Güter darstellen. IP umfasst all solche Intangibles, die rechtlich durch ein spezifisches Regime geschützt sind (beispielsweise Patente und Marken). 


\subsubsection{Wesensart von Marken und Brands}

Eine Marke ist das einzige von staatlicher Seite gewährte Immaterialgüterrecht, welches ad infinitum verlängert werden kann. Sie kann als Zeichen, das geeignet ist, Waren oder Dienstleistungen eines Unternehmens von denjenigen anderer Unternehmen zu unterscheiden, definiert werden. ${ }^{836}$

Insofern erfüllt sie sowohl die Herkunfts- als auch die Unterscheidungsfunktion. Beide Funktionen sind für die Einschätzung von Eintragungsfähigkeit und Verletzung von Marken von zentraler Bedeutung.

Das rechtliche Konstrukt Marke ist jedoch in der praktischen Anwendung nie getrennt von, sondern immer verbunden mit Marketing-Elementen, die zusammen mit der Marke die Identität und das Image der Brand ausmachen und somit entscheidend sind für den Markterfolg. In Kombination mit diesen wird die Marke zum Marketinginstrument Brand. Daher ist eine Brand eine Marke (nur) insoweit, als sie durch das Markenrecht geschützt ist. Eine Brand besteht also aus viel mehr als (nur) aus einer oder mehreren Marke(n). ${ }^{837}$ Aufgrund dieses Zusammenhangs befasst sich die vorliegende Arbeit mit Bewertung von Brands und nicht lediglich von Marken. ${ }^{838}$

Eine Marke (im Sinne von Brand) ist ein komplexes persönlichkeitsähnliches Phänomen, welches die zusammenhängenden Komponenten Markenidentität und Markenimage aufweist. Sie kann definiert werden als Bündel spezifischer Vorteile, welche sicherstellen, dass es sich aus der Sicht der relevanten Zielgruppen stark von anderen Bündeln, welche dieselben Bedürfnisse befriedigen, unterscheidet.

Die sog. Brand Achievements sind Teil der Markenidentität. Sie umfassen u.a. alle zielgruppenbezogenen Zeichen (auch Devices genannt), wie zum Beispiel Logos, Töne oder spezifisch kreierte Düfte, von denen einige als Marken (im rechtlichen Sinne) schützbar sind.

Marken beeinflussen fast jeden Unternehmensbereich. Daher müssen sie ganzheitlich gemanagt werden. Erfolgreiches Markenmanagement führt dazu, dass die jeweiligen Marken eine starke und positive Kundenbeziehung bilden und

836 Vgl. Art. 4 CTMR.

837 Und ist daher kein IP-Recht, gehört jedoch zur Gruppe der Intantibles.

838 Der Einfachheit halber (in Anlehnung an den verbreiteten Sprachgebrauch im juristischen Bereich und um weitere Anglizismen zu vermeiden) soll jedoch in der Regel von Marken die Rede sein, obwohl meistens Brands gemeint sind. 
aufrechterhalten. Außerdem werden Risiken minimiert und Transaktionskosten auf beiden Seiten gespart. Zudem werden Kapitalkosten gesenkt. Starke Marken können zudem für den Inhaber strategische Optionen eröffnen und für die internen und externen Zielgruppen soziale Prestigefunktionen erfüllen, v.a. im Sektor der Luxusmarken.

\subsubsection{Einführung in die Markenbewertung}

Verglichen mit der Bewertung materieller Güter ist die Markenbewertung eine relativ junge Disziplin. Wissenschaft und Praxis haben sich erstmals auf breiter Basis mit dem Thema aufgrund der vielen markenfokussierten Unternehmensübernahmen der 1980er Jahre beschäftigt. Eine große Zahl an Markenbewertungsmethoden sind seitdem entwickelt worden, sowohl für Bilanzierungs- als auch für Managementzwecke.

Da der in einer idealen transparenten Markttransaktion festgelegte Preis den Wert des jeweiligen Vermögensgegenstandes am besten ausdrückt, kann Markenwert als die geschätzte Menge finanzieller Mittel, für welche die Marke zwischen informierten unabhängigen Parteien zu Marktbedingungen weitergegeben wird definiert werden. Jede gute Markenbewertung sollte sich dieser Idealdefinition daher so gut wie möglich annähern.

Bei Marken (im Sinne von Brand) und IP-Rechten ist jedoch die Besonderheit zu beachten, dass kaum funktionierende Marktmechanismen bestehen und diese Intangibles sich durch einen hohen Grad an Kontextabhängigkeit und Einzigartigkeit auszeichnen, daher schlecht mit anderen Marken bzw. anderen IP-Rechten vergleichbar sind. Daher kann man im Rahmen einer Markenbewertung in der Regel nicht auf Marktdaten vergleichbarer Transaktionen bzw. vergleichbarer Marken zurückgreifen. Die gangbare Alternative zur Annäherung an die o.g. Definition ist, bei Bewertung so viele quantitative und qualitative Informationen wie möglich über das Objekt, z.B. eine Marke, zu sammeln und zu analysieren. Hierzu gehören beispielsweise solche Eigenschaften wie die Fähigkeit, diverse Risiken zu minimieren.

Eine auf diese Weise durchgeführte ganzheitliche Bewertung führt zu verlässlichen Ergebnissen auf solider Informationsgrundlage, kombiniert mit bestmöglichem Verständnis aller wertbezogenen Eigenschften des jeweiligen IPRechts. Die so genommenen Bewertungsergebnisse sind sowohl im Rahmen des Marken- und IP-Management als auch der Verwertung von Nutzen. 


\subsubsection{Anlässe zur Markenbewertung}

Die Tatsache, dass Marken fast jeden Unternehmensbereich betreffen spiegelt sich auch in den vielen verschiedenen Markenbewertungsanlässen wider. Unter anderem müssen Marken im Rahmen des strategischen und operativen Markenmanagements, des Markencontrollings, bei Markentransaktionen (z.B. M\&A und Lizenzierung), Markenfinanzierung und im Rahmen der Markenschutzstrategie bewertet werden. All diese Anlässe haben gemein, dass zukünftige Entwicklungen auf der Basis gegenwärtig verfügbarer Daten eingeschätzt werden müssen. Daher erfordern sie auch strategische zukunftsbezogene, oder forecasting, Bewertungen.

Im Gegensatz dazu sind Bilanzierung, Steuern und die Bestimmung der Höhe des Schadensersatzes vor Gericht Anwendungsgebiete von vergangenheitsbezogenen (reporting) Bewertungen. Hier ist die IP-Bewertung auf Dokumentation fokussiert und wird in erster Linie ex post vorgenommen (was bedeutet, dass genau festgesetzte Endergebnisse errechnet werden können). In einigen Fällen gibt es sogar Sonderregeln, welche die Anwendung bestimmter Bewertungstechniken vorschreiben.

\subsection{Markenbewertung - der derzeitige Stand}

Es existieren momentan allein zum Zweck der Bewertung von Marken weltweit mehr als dreihundert verschiedene Methoden. Da nach wie vor Uneinigkeit bezüglich der Qualität dieser Ansätze herrscht, konnte sich bisher keine Methodik durchsetzen.

\subsection{1 Überblick über die momentane Markenbewertungslandschaft}

Markenbewertungsmodelle können zu Analyse- und Vergleichszwecken in drei Gruppen eingeteilt werden: finanzielle, kundenpsychologische und hybride (die ersten beiden Gruppen kombinierende) Verfahren. In jeder Gruppe existieren generische, also allgemein zugängliche, und proprietäre Verfahren. Trotz steigender Bekanntheit firmenintern entwickelter Ansätze wenden deutsche Unternehmen vorwiegend generische an. Rein finanzielle und psychologisch orientierte Verfahren werden laut aktueller Studien am meisten genutzt, 
wobei nur circa vierzig Prozent aller deutscher Unternehmen mit Marken diese überhaupt bewerten oder mindestens einmal bewertet haben. Trotz eines leichten Aufwärtstrends bleibt das Ausmaß der praktischen Anwendung der Markenbewertung demnach hinter ihrer allgemein wahrgenommenen Wichtigkeit zurück.

Diese Situation ist nicht nur nachteilig für Anbieter von Markenbewertungen, sondern auch und vor allem für die Marken selbst, da ihr volles Potential als Vermögensgegenstand ohne den Informationszufluss aus ganzheitlichen Bewertungen nicht ausgeschöpft werden kann.

Die teilweise Markenbewertungsabstinenz erklärt sich hauptsächlich aus der Meinung, dass keine tauglichen Bewertungsverfahren existieren und nicht etwa daraus, dass so eine Bewertung weder benötigt noch nutzbringend sei.

\subsubsection{Analyse gängiger Markenbewertungsmethoden}

Sämtliche Markenbewertungsmethoden haben spezifische Vor- und Nachteile. Finanzielle Verfahren ermitteln den Markenwert in der Regel über markenspezifische Erträge, Marktvergleiche mit anderen Marken oder Kosten der Entwicklung und Übernahme von Marken (Ertragswert-, Marktwert- und Kostenansatz). Beim Kostenansatz ist allein schon die Tatsache problematisch, dass ein zukunftsbezogener Markenwert auf Basis historischer Daten ermittelt werden soll. Marktvergleiche scheitern in der Regel bereits an der Tatsache, dass es keine transparenten Märkte für Marken gibt. Der Ertragswertansatz liefert einen recht brauchbaren Ansatzpunkt für die Wertfindung, da er mit wichtigen Wertindikatoren, den Erträgen, arbeitet. Doch bestehen nicht nur Probleme bei deren Schätzung; es wird auch eine Vielzahl anderer wertbildender Faktoren, zum Beispiel die Markenstärke aus Konsumentensicht, auer Acht gelassen.

Hier setzen die kundenpsychologischen Verfahren an. Sie bilden im Allgemeinen die aus der Sicht der Markenzielgruppen wertbildenden Faktoren ab. Allerdings führen sie zu keiner finanziellen Ausgabegröße und sind daher für viele Bewertungsanlässe unbrauchbar.

Um diese Probleme zu überwinden, verbinden hybride Verfahren finanzielle Methoden (in der Regel ertragswertbasierte Verfahren) mit kundenpsychologischen Faktoren. Vorteilhaft an diesen Verfahren ist, dass sie aufgrund der 
Errechnung von finanziellen Markenwerten in Kombination mit Berücksichtigung qualitativer Einflussgrößen in fast allen Bewertungsszenarien angewendet werden können. Andererseits werden oft nicht alle relevanten wertbildenden Faktoren berücksichtigt. Außerdem sind diese Methoden meist nicht flexibel genug, um der unterschiedlichen Bedeutung der einzelnen Faktoren Rechnung zu tragen.

\subsubsection{Schlussfolgerungen}

Die momentane Markenbewertungslandschaft ist von Gegensätzlichkeiten gekennzeichnet. Auf der einen Seite gibt es generische finanzielle und psychographische Methoden, welche trotz ihrer begrenzten Eignung im Rahmen ganzheitlicher Bewertungen die höchsten Marktanteile haben. Sie decken den Bedarf an einfachen, überschaubaren Bewertungen, die auf einen bestimmten Aspekt fokussiert sind. Solche Methoden werden z.B. im Markenmanagement angewandt, um die Stärke der eigenen Marken im Verhältnis zu denjenigen der Konkurrenz zu messen.

Auf der anderen Seite bergen hybride Methoden (welche alle proprietär zu sein scheinen) das Potenzial, für umfassende Bewertungen viel besser geeignet zu sein. Ihre Marktanteile sind jedoch umgekehrt proportional zu diesem Potenzial. Dies liegt hauptsächlich an zwei Gründen. Zunächst einmal scheint jede dieser Methoden zumindest einen erheblichen methodischen Fehler aufzuweisen, wie z.B. die Auslassung wichtiger wertbeeinflussender Faktoren. Des Weiteren sind zentrale Prozesse dieser Methoden oft unflexibel und intransparent, also eine sog. 'Black Box'. Dies vereitelt einen notwendigen Grad an Replizierbarkeit und dadurch hervorgerufenes Vertrauen, welches zu größeren Marktanteilen führen könnte. Da bisher proprietäre hybride Verfahren den von ihrer grundlegenden Systematik her möglichen Zusatznutzen im Verhältnis zu den generischen Verfahren nicht realisiert haben, haben viele potenzielle Kunden es bisher unterlassen, finanzielle Ressourcen für solche Bewertungen bereitzustellen. Momentan angebotene proprietäre Verfahren scheinen im Vergleich zu frei verfügbaren generischen für viele Bewertungsanlässe das Investment nicht wert zu sein.

Die Meinung, dass bisher keine umfassend brauchbare Markenbewertungsmethode auf dem Markt existiert, ist daher durchaus gerechtfertigt. Letztlich zielen alle derzeitigen monetären Markenbewertungsverfahren (d.h. sol- 
che mit einem in finanziellen Größen dargestellten Endergebnis) darauf ab, eine unsichere Zukunft in einem finanziellen Wert auf der Basis einer nur lückenhaft erfassten Gegenwart abzubilden. ${ }^{839}$

\subsection{Entwicklung eines eigenen Ansatzes}

Stattdessen sollte man das Verständnis gegenwärtiger bewertungsrelevanter Umstände verbessern, um bewertungsbegleitende Risiken, Informationsdefizite bzw. -Asymmetrien und Unschärfen weitestgehend zu minimieren.

Um dies zu erreichen, wird in der vorliegenden Arbeit eine neue IP-Bewertungsmethode entwickelt (für Zwecke dieser Arbeit genannt 'Systematic Integrated Methodology' oder 'SIM'). Mit dieser Methode kann auf systematische, umfassende und flexible Art und Weise ein kontextbezogener monetärer Wert im Rahmen von forecasting-Bewertungen ermittelt werden.

\subsection{1 Überblick über den Bewertungsprozess}

Aufbauend auf den oben dargelegten grundlegenden Aspekten des Wertes von IP-Rechten und auf Schlussfolgerungen aus der Analyse momentan angewandter Markenbewertungsverfahren stellt im Rahmen der SIM zunächst eine allgemein anerkannte finanzielle Methode den ersten Rechenschritt dar. Als zweiter schritt wird eine kontextbezogene qualitative Evaluierung, genannt 'Prismatic Evaluation', durchgeführt. Sie stellt das Herzstück der SIM dar und wurde eigens für diesen Zweck entwickelt.

\subsubsection{Finanzielle ertragswertbasierte Analyse}

Eine finanzielle ertragswertbasierte Analyse bestehend aus Discounted Cash Flow-Berechnung und Entscheidungsbaumanalyse stellt den ersten der zwei Hauptteile der SIM dar. Diese Methodik wird im Rahmen verschiedener Bewertungen, auch von Patenten und Marken, verhältnismäßig oft angewandt.

839 Einschränkend sei darauf hingewiesen, dass die Analyse der verfügbaren Markenbewertungsmethoden auf Basis allgemein zugänglicher Daten durchgeführt wurde. Da jedoch vor allem die Anbieter proprietärer, hybrider Bewertungsverfahren diese nur in relativ groben Zügen offenlegen, ist es durchaus möglich, dass eine umfassende - von außen nicht durchführbare - Analye ergäbe, dass die hier genannten Kritikpunkte in einigen Fällen weniger stark oder gar nicht zutreffen. 
Im Rahmen der SIM wird sie als einfach handzuhabendes Mittel eingesetzt, um eine erste Version des sich bei zukunftsbezogenen Bewertungen zwangsläufig ergebenden Wertebereiches zu errechnen. Zugleich ermöglicht diese Vorgehensweise, eine finanzielle Ausgabegröße zu erzielen. Im Rahmen von Bewertungssituationen mit zwei oder mehr Parteien hilft dieser Rechenschritt, den Verhandlungsprozess zu systematisieren.

Solch eine finanzielle Analyse wäre als alleiniges Bewertungsverfahren für Zwecke strategischer forecasting-Bewertungen zu begrenzt und unflexibel, da sie nur eine Art finanzieller Daten operationalisiert, wenn auch eine wichtige: erwartete zukünftige Zahlungsströme, die direkt auf die zu bewertende Marke zurückzuführen sind. Daher stellt das Ergebnis der finanziellen ertragswertbasierten Analyse lediglich eine erste grobe, jedoch brauchbare, Schätzung dar.

Um jedoch ein möglichst realistisches Bewertungsergebnis zu erhalten, ist es unverzichtbar, so viele nützliche Informationen wie nötig und möglich, finanzielle und nicht-finanzielle, quantitative sowie qualitative, in den Bewertungsprozess einzubeziehen. Je mehr Informationen der Bewerter über das Bewertungsobjekt zusammenträgt, desto besser wird er dessen Charakteristika, Chancen und Risiken - also in der Gesamtschau dessen Wert - beurteilen können. Daher muss die finanzielle Analyse durch einen umfassenden Prozess, durch den auch qualitative wertbildende Faktoren abgebildet werden hier die sog. 'prismatische Evaluation' - ergänzt werden.

\subsubsection{Prismatische Evaluation}

Im Wege der prismatischen Evaluation werden qualitative und quantitative Informationen, die mit dem Wert des Bewertungsobjekts in Zusammenhang stehen, als Eingabegrößen in den Bewertungsprozess eingebunden.

Es werden vier Gruppen beziehungsweise Dimensionen wertbezogener Eigenschaften unterschieden; dies sind rechtliche, wirtschaftlich-strategische, technische und finanzielle. Indem man diese vier Dimensionen im Zuge der Bewertung abdeckt, stellt man sicher, dass alle wichtigen Aspekte berücksichtigt werden können. Dies ist besonders wichtig, wenn es um die Bewertung geistigen Eigentums geht, da der Wert dieser Art von Vermögensgegenständen in hohem Maße davon abhängig ist, in welchem Zusammenhang der jeweilige Vermögensgegenstand steht (im Verhältnis zu anderen Gegenständen, 
innerhalb des jeweiligen Unternehmens etc.).

Jede der sogenannten 'vier Dimensionen des Wertes' wird separat in einem Scoring-Modell analysiert, bevor die vier Ergebnisse zu einem Punktwert als Zwischenergebnis zusammengefasst werden. Daraufhin wird dieser Punktwert mit dem Ergebnis der finanziellen Analyse so zusammengeführt, dass man eine finanzielle Ausgabegröße als Endergebnis erhält, die jedoch nicht nur die finanziellen, sondern auch alle anderen wertbeeinflussenden Faktoren wiederspiegelt.

So entsteht eine umfassende, flexible und nachvollziehbare Bewertungsmethodik, die für alle zukunftsbezogenen Markenbewertungsanlässe, vor allem für das Markenmanagement und alle Markentransaktionen, Anwendung finden kann. Mit entsprechenden Anpassungen im Detail ist sie auch für alle anderen geistigen Eigentumsrechte verwendbar, da sie auf Faktoren beruht, die für die Wertbildung all dieser Rechte gleichermaßen gelten. Dieser Bewertungsansatz unterstützt nicht nur die Ermittlung realistischer Werte, sondern erlaubt auch Unternehmen, ihre verschiedenen geistigen Eigentumsrechte als Vermögensgegenstände bestmöglich zu vergleichen und zu verwerten.

\subsection{Die rechtliche Dimension des Markenwertes}

Von allen vier Dimensionen des Markenwertes wurde die rechtliche schwerpunktmäßig ausführlich beleuchtet. Obwohl rechtlichen Aspekten im Wege der Markenbewertung in der Regel nicht die Hauptaufmerksamkeit zuteil wird, sind sie doch in zwei Aspekten entscheidend: zunächst ermöglicht (neben Geheimhaltung) der rechtliche Markenschutz rechtliche Knappheit, die im allgemeinen die Grundvoraussetzung für die Wertbildung darstellt und das jeweilige geistige Eigentum zum Vermögensgegenstand werden lässt. Des weiteren existieren verschiedenste rechtliche Aspekte, die den Wert der jeweiligen Marke beeinflussen, z.B. Unterscheidungskraft, graphische Darstellbarkeit und Verwechslungsgefahr. 


\subsubsection{Qualitativer Schutzbereich - Unterscheidungskraft,}

Freihaltebedürfnis und graphische Darstellbarkeit

In Fällen, in denen die jeweilige Marke keine Unterscheidungskraft besitzt, die markierten Produkte oder Dienstleistungen beschreibt oder nicht graphisch darstellbar ist, entsteht kein rechtlicher Markenschutz. Gerade für junge Marken ist es in solchen Situationen nahezu unmöglich, ohne den abgesteckten Raum an Handlungsfreiheit, die der rechtliche Schutz bietet, im Markt zu bestehen.

Wenn der qualitative Schutzbereich eröffnet ist, hängt seine Verbindung zum Markenwert davon ab, ob der jeweilige Aspekt eine Frage von 'ja' oder 'nein' ist (wie bei der graphischen Darstellbarkeit) oder ob eine qualitative Skala existiert, beispielsweise von geringer über mittlere bis zu hoher Unterscheidungskraft. In letzteren Fällen existiert kein von vornherein festgelegtes Verhältnis von zu untersuchendem Charakteristikum und Wert der jeweiligen IP - dieses hängt immer von den genau zu analysierenden Umständen des Einzelfalls ab. Man kann hier nur allgemeine Aussagen treffen, beispielsweise dass die Marke desto stärker und ihr Wert umso höher ist, je höher ihr Grad an Unterscheidungskraft ist. Man muss im Falle dieses Beispiels jedoch beachten, dass starke Marken einem gewissen Risiko ausgestzt sind, generisch zu werden.

Die Art des Zeichens, sei es ein herkömmliches wie eine Wortmarke oder eine neuere Markenform, z.B. eine Farbkombination, steht mit dem Markenwert in indirektem Zusammenhang. Wäre beispielsweise in Zukunft die Registrierung von Duftmarken möglich, würden die ersten solcher Marken aus der Masse an Marken deutlich hervorstechen und hätten dadurch das Potential überdurchschnittlich wertvoll zu sein. Andererseits könnten die angesprochenen Verkehrskreise das jeweilige Zeichen nicht unbedingt als Herkunftsnachweis auffassen - ein Problem, das bei allen neueren Markenformen besteht und den Wert der jeweiligen Marke herabsetzen oder zunichte machen kann. Was Düfte betrifft, kommt hinzu, dass diese im Rahmen des Branding heute schon weit verbreitet eingesetzt werden, jedoch mit dem Ziel, die Konsumenten eher unterschwellig zu beeinflussen, d.h. nicht bewusst als Herkunftshinweis wahrgenommen zu werden. 


\subsubsection{Quantitativer Schutzbereich - die Markenklassen}

Grundsätzlich wächst der Wert einer Marke mit der Anzahl der Klassen, für die sie eingetragen ist. Je mehr Produkte oder Dienstleistungen markiert werden können, umso mehr Märkte können bedient werden. Jedoch muss die jeweilige Marke auch entsprechend in allen ihren Klassen genutzt werden, um nicht löschungsreif zu werden. Daher ist es wichtig, sich schon bei Anmeldung einer Marke darüber Gedanken zu machen, in welchen Bereichen die Marke wohl tatsächlich ernsthaft genutzt werden wird. In diesem Zusammenhang spielt auch die Tatsache eine Rolle, dass die Kosten für Eintragung und Aufrechterhaltung einer Marke mit der Anzahl der designierten Klassen steigen. Dies muss gegen die erwarteten Zahlungsströme aus der Nutzung der Marke abgewogen werden.

Ein allgemeingültiger direkter Zusammenhang zwischen bestimmten Klassen und einem gewissen Wert der jeweiligen Marke existiert nicht. Ein solcher Zusammenhang ist von verschiedenen Faktoren abhängig, die im Einzelfall $\mathrm{zu}$ analysieren sind.

\subsubsection{Geographischer und zeitlicher Schutzbereich}

Ähnlich wie beim quantitativen Schutzbereich kann man auch bezüglich dem geographischen Schutzbereich die allgemeine Regel aufstellen, dass der Wert einer Marke mit dem von ihr abgedeckten Territorium wächst. Auch hier ist dies jedoch eine Frage des Einzelfalls und es müssen Kosten und Nutzen abgewogen werden. Letztlich kommt es darauf an, ob die jeweilige Marke in den Ländern Schutz genießt, in denen Marketingaktivitäten in Übereinstimmung mit der Unternehmensstrategie stattfinden.

Der zeitliche Schutzbereich ist in den Jahren bevor die erste Verlängerung fällig wird von geringer Bedeutung für den Markenwert. Ein Zusammenhang zwischen Anzahl der Schutzdauerverlängerungen und Markenwert kann im Grunde angenommen werden, muss sich jedoch notwendigerweise auf registrierte Marken beschränken und und stellt vor dem Hintergrund des Unterschieds zwischen Marken und Brands keine immer zwingende Schlussfolgerung dar. 
7.5.4 Entstehung des Markenschutzes: registrierte und nicht registrierte Marken

Fehlender Registerschutz ist - außer in Fällen von Benutzungsmarken und notorisch bekannten Marken - in der Regel ein stark wertmindernder beziehungsweise wertzerstörender Faktor. Eine ordnungsgemäße Markenregistrierung ist jedoch kein Aspekt, der sich spiegelbildlich als stark werterhöhend auswirkt. Vielmehr ermöglicht sie durch die Schaffung rechtlicher Knappheit das Potential der jeweiligen Marke, einen gewissen Wert zu entwickeln. Darüber hinaus müssen die im Rahmen der Registrierung entstehenden Kosten mit dem zu erwartenden Nutzen strategisch abgewogen und gegebenenfalls (im Zuge der finanziellen Dimension des Markenwerts) von erwarteten Zahlungsströmen abgezogen werden.

Bei der Entstehung des Markenschutzes von notorisch bekannten Marken und Benutzungsmarken kommt es auf die Frage an, ob notorische Bekanntheit beziehungsweise Verkehrsgeltung vorliegt. Diese Frage ist in der Regel nur mit deutlich höherem finanziellen Aufwand zu beantworten als die nach einer formellen Eintragung. Des weiteren müssen erhebliche finanzielle Mittel aufgewendet werden, damit die betreffende Marke den Status der Verkehrsgeltung beziehungsweise der notorischen Bekanntheit überhaupt erreichen kann. Diese Kosten müssten bei der Bewertung negativ zu Buche schlagen. Andererseits ist zu bedenken, dass Benutzungsmarken und notorisch bekannte Marken aufgrund ihrer überdurchschnittlich hohen Bekanntheit ein höheres und stabileres Markeneinkommen generieren können als andere Marken.

\subsubsection{Benutzung}

Fehlende ernsthafte Benutzung einer Marke führt nach Ablauf der Benutzungsschonfrist beziehungsweise nach Ablauf von fünf Jahren zu irgendeiner Zeit während des Markenschutzes zur Löschungsreife, kann also den Markenwert erheblich bedrohen. Auch hier sind die potentiell negativen Auswirkungen des Fehlens einer ernsthaften Benutzung auf den Markenwert stärker als die positiven Implikationen bei Vorliegen der ernsthaften Benutzung. 


\subsubsection{Inhaberschaft und andere Rechtstitel}

Je stärker die Rechtsposition ist, die man an der jeweiligen Marke inne hat, das heißt je näher am uneingeschränkten Eigentum, desto mehr Möglichkeiten der Nutzung und Verwertung hat man. Da Nutzung und Verwertung der Marke Eckpfeiler der Schaffung von Markenwert sind, ist grundsätzlich das uneingeschränkte Eigentum an der Marke deren Wertentwicklung zuträglicher als eine eingeschränkte Rechtsposition wie zum Beispiel die des Nehmers einer einfachen Lizenz. Auch hier kommt es jedoch immer auf eine Einzelfallbetrachtung an.

\subsubsection{Amts- und Gerichtsverfahren; Vergleich}

Der Fortschritt einer Markenanmeldung im Amtsverfahren und der Status einer Marke in einem etwaigen Gerichtsverfahren wirken sich direkt auf deren Schutzbereich und die ihr zuzuordnenden Kosten aus und daher auch auf den Markenwert. Obwohl bereits eine Markenanmeldung einen gewissen Wert hat, festigt sich die Rechtsposition der Marke und damit ihr Wertpotential mit der Anzahl an Verfahrenshürden, die sie genommen hat. Es muss also nicht nur der Status des Amtsverfahrens und etwaiger Gerichtsverfahren beziehungsweise deren Risiko geklärt, sondern es müssen auch Optionen für außergerichtliche Streitbeilegung ausgelotet werden. Letztere kann in erheblichem Maße Zeit und Kosten sparen. Sogar der Ruf, in Widerspruchsverfahren mit Härte vorzugehen, kann Kosten einsparen, da dies für die Gegenseite einen Anreiz darstellt, sich mit Beendigung des Verfahrens durch Vergleich zufrieden zu geben.

\subsubsection{Verwechslungsgefahr und Markenschutz darüber hinaus}

Wenn sich die Gegenpartei erfolgreich auf Verwechslungsgefahr beruft, bringt dies die verletzende Marke zu Fall. Dies dürfte in den meisten Fällen desaströse Auswirkungen auf den Wert der dazugehörigen Brand haben, da die rechtlich abgesteckte Handlungsfreiheit wegfällt. Daher muss die Verwechslungsgefahr beziehungsweise die Wahrscheinlichkeit ihres Vorliegens im Rahmen jeder Markenbewertung geprüft werden. Die Intensität dieser Prüfung richtet sich nach den Anhaltspunkten im Einzelfall; es existiert keine feste Korrelation von Größe der Verwechslungsgefahr und Markenwert. 
Im allgemeinen weisen Brands, deren Marke(n) bekannt im Sinne des Art. 8(5) der Gemeinschaftsmarkenverordnung ist/sind, einen höheren Wert auf als Brands, bei denen dies nicht der Fall ist. Selbiges gilt für notorisch bekannte Marken. Diese Erweiterung des Markenschutzes über Fälle von Verwechslungsgefahr hinaus ist Ausdruck der Tatsache, dass das Markenrecht als Teil des Wettbewerbsrechts im weiteren Sinne den um die Marke gebildeten Handelswert (also die Brand) zu schützen beabsichtigt.

\subsubsection{Vertragliche Einschränkungen}

Abhängig von seinem Inhalt, der Art und Weise seiner Durchführung und vom Markterfolg der mit den lizenzierten Rechten erstellten Produkte beziehungsweise der angebotenen Dienstleistungen kann das Bestehen eines Lizenzvertrags dem Markenwert zu- oder abträglich sein. Obwohl die Höhe der vereinbarten Lizenzgebühren eine wichtige Einflussgröße für den Markenwert ist, können andere Faktoren auch von großer Bedeutung sein. Beispielsweise kann der Markenwert negativ beeinflusst werden, wenn sich herausstellt, dass eine exklusive Markenlizenz nicht in gewünschter Weise zur Entwicklung der Marke genutzt wird und für diesen Fall nicht vertraglich vorgesorgt wurde.

Abgrenzungsvereinbarungen wirken sich in der Regel positiv auf den Markenwert aus, da sie sowohl Rechtssicherheit vermitteln als auch Zeit und Kosten einsparen helfen. 



\section{Bibliography}

Aaker, David A.: Building strong brands, New York 1996

Aaker, David A.: Management des Markenwerts, Frankfurt am Main 1992

Abelson, Jenn: Merchants X out A, E, I, O and U, http://www.boston.com/busin ess/articles/2006/03/19/merchants_X_out_a_e_i_o_and_u/ (last viewed April $26,2006)$

Accounting Standards Committee of Germany: FAQ (Frequently asked questions), http://www.standardsetter.de/drsc/faq.html (last viewed September 12, 2005)

Achleitner, Ann-Kristin; Schraml, Stephanie; Nathusius, Eva: Valuation of Platform Technology Based Intangibles Companies, Working Paper No. 2007-02, February 2007, Center for Entrepreneurial and Financial Studies, Technische Universität München

ACNielsen: ACNielsen Brand Performance. Valide Markenbewertung, PowerPoint presentation,

http://www.konzept-und-markt.com/Docs/ACNBrandPerformance.pdf (last viewed March 26, 2007)

Added Value: Die Wurzeln von Icon Added Value: Der Markenerfolg., http://ww w.added-value.com/av/de/Werwirsind/Geschichte/tabid/421/Default.aspx (last viewed February 12, 2007)

Amirkhizi, Mehrdad: Suche nach der Weltformel, Press release of the Intsitut für Markenwert, http://www.institutfuermarkenwert.de/Suche (last viewed August 23, 2005)

Andersen, Brigitte; Striukova, Ludmila: Intangible Assets and Intellectual Capital: Where Value Resides in the Modern Enterprise, School of Management and Organizational Psychology Working Paper Series, 04/02, http://www.bbk. ac.uk/manop/research/wpapers/mandocs/04_02_andersen.pdf (last viewed October 16, 2006)

Anson, Weston; Suchy, Donna (ed.): Fundamentals of Intellectual Property Valuation: A Primer for Identifying and Determining Value, Chicago 2005

Anson, Weston: Intellectual Capital: Understanding the Value and the Risk, article of July 19, 2005 on www.ipfrontline.com, http://www.ipfrontline.com/dept s/article.asp?id=3674 \\&deptid=3 (last viewed November 21, 2005)

Audörsch, Jörg: Moderne Bewertungsverfahren für Aktien, http://finanzportal.wiwi.uni-sb.de/fund/Inhalt.htm (last viewed February $8,2008)$ 
Ballwieser, Wolfgang: Unternehmensbewertung - Prozess, Methoden und Probleme, Stuttgart 2004

Bamert, Thomas: Markenwert, Wiesbaden 2005

Bank for International Settlements: International Convergence of Capital Measurement and Capital Standards. A Revised Framework, Basel 2004

Barsky, Noah P.; Marchant, Garry: The Most Valuable Resource: Measuring and Managing Intellectual Capital, http://www.greentreecapital.com/ec-measur ing-managing.html (last viewed May 3, 2007)

Battersby, Gregory J.; Grimes, Charles W.: Licensing Royalty Rates, Gaithersburg 2006

Bauer, Michael E.: Verrechnungspreise für immaterielle Wirtschaftsgüter des Anlagevermögens, Frankfurt am Main 2000

Baumgarth, Carsten: Markenpolitik. Markenwirkungen - Markenführung - Markencontrolling, 2nd ed., Wiesbaden 2004

Becker, Wolfgang; Lutz, Stefan: Gabler Kompakt-Lexikon modernes Rechnungswesen, Wiesbaden 2002

Beisel, Wilhelm; Klumpp, Hans-Hermann: Der Unternehmenskauf, 5th ed., Munich 2006

Bekmeier-Feuerhahn, Sigrid: Marktorientierte Markenbewertung. Eine konsumenten- und unternehmensbezogene Betrachtung, Wiesbaden 1998

Bender, Achim: Europäisches Markenrecht. Einführung in das Gemeinschaftsmarkensystem, Cologne/Munich 2007

Benker, Thomas: Bewertung und Bilanzierung von Marken nach HGB, IAS und US-GAAP, 2nd ed., Blaubeuren 2004

Bentele, Guenter; Buchele, Mark-Steffen; Hoepfner, Joerg; Liebert, Tobias: Markenwert und Markenwertermittlung, Wiesbaden 2003

Bentele, Martina: Immaterielle Vermögenswerte in der Unternehmensberichterstattung, Frankfurt am Main 2004

Berger, Mathis: Aspekte der Bewertung von Marken in Unternehmensvermögen, MarkenR 1999, p. 271 et seq.

Berlit, Wolfgang: Markenrecht, 6th ed., Munich 2005

Berman, Bruce; Woods, James D.: Patent "Brands" - Positioning IP for Shareholder Value, in: Berman, Bruce (ed.): From Ideas to Assets. Investing Wisely in Intellectual Property, New York 2002, pp. 211-232

Binder, Christof U.: Lizenzierung von Marken, in: Esch, Franz-Rudolf (ed.), Moderne Markenführung. Grundlagen - Innovative Ansätze - Praktische Umsetzungen, 4th ed., Wiesbaden 2005, p. 523 et seq.

Bingener, Senta: Markenrecht - ein Leitfaden für die Praxis, Munich 2007

Böhler, Heymo; Scigliano, Dino: Marketing-Management, Stuttgart 2005

B.R. Brand Rating: Monetäre Markenbewertung auf Zielgruppen- und Marktbasis. Markenführung mit BRAND RATING, slide presentation, http://www.markenlexikon.com/d_texte/verfahren_brand_rating.pdf (last viewed November 16, 2006) 
Brand Finance: Current Practice in Brand Valuation, http://www.brand finance.com/Uploads/pdfs/Current_Practice_in_Brand_Valuation.pdf (last viewed April 28, 2006)

Brand Finance: Implications of the new international accounting standards for intellectual property owners, Brand Finance Report, http://www.brandfinance.com/uploads/pdfs/ayntka_IFRS3.pdf (last viewed May 9, 2007)

Brealey, Richard A.; Myers, Stewart C.: Principles of Corporate Finance, 7th ed., Boston 2003

Brooking, Annie: Intellectual capital, London 1996

Brückner, Ingo: Monetäre Bewertung von Patentportfolios, VPP-Rundbrief Nr. 4/2005, p. 149 et seq.

Brügger, Urs; Streibel, Michael: Neue Transfer Pricing Dokumentationspflichten in Deutschland, Steuer Revue 2003, p. 598 et seq.

Burmann, Christoph; Blinda, Lars; Nitschke, Axel: Konzeptionelle Grundlagen des identitätsbasierten Markenmanagements, LiM-Arbeitspapiere, Universität Bremen, Fachbereich Wirtschaftswissenschaft, Arbeitspapier Nr. 1 (2003), http://www.lim.uni-bremen.de/download-files/LiM-AP-01-Identitaetsbasie rtes-Markenmanagement.pdf (last viewed June 25, 2007)

Burmann, Christoph; Meffert, Heribert: Theoretisches Grundkonzept der identitätsorientierten Markenführung, in: Meffert, Heribert; Burmann, Christoph; Koers, Martin (ed.): Markenmanagement. Identitätsorientierte Markenführung und praktische Umsetzung, 2nd ed., Wiesbaden 2005, p. 37 et seq.

Burmann, Christoph; Meffert, Heribert; Koers, Martin: Stellenwert und Gegenstand des Markenmanagements, in: Meffert, Heribert; Burmann, Christoph; Koers, Martin (ed.): Markenmanagement. Identitätsorientierte Markenführung und praktische Umsetzung, 2nd ed., Wiesbaden 2005, p. 3 et seq.

Caldwell, Allan: How IFRSs put brands on the balance sheet, http://www.intangib lebusiness.com/store/data/files/78-IB_Viewpoint_How_IFRSs_put_brands_o n_the_balance_sheet.pdf (last viewed March 3, 2008)

Casley, Andrew: Tax. Introduction to tax and IP, http://www.pwc.com/gx/eng/i ns-sol/publ/ipvalue/Introduction-tax-IP-05.pdf (last viewed August 3, 2007)

Chen, Nan: Asymmetric Information, the Choice of Financial Distress Resolution and Implications for Corporate Debt Pricing, New York 2003

Cheridito, Yves: Markenbewertung, Berne 2003

Coenenberg, Adolf G.: Kostenrechnung und Kostenanalyse, 5th ed., Stuttgart 2003

Cowie, Anthony (chief ed.): Oxford Advanced Learner's Dictionary, 4th ed. 1989, 6th impression 1993

Davies, Isabel M. (ed.): Sweet \& Maxwell's European trade mark litigation handbook, London 1998

Degen, Patrick: Die Bewertung von Marken aus rechtlicher Sicht, in: Corporate Brand Management - Ein Forschungsprojekt der HSW Bern, p. 103 et seq. 
Deichsel, Alexander: Markentechnische Beobachtungen zum Markenschutz, GRUR 1998, p. 336 et seq.

Deutsche Bundesbank: Monetary policy and investment behaviour - an empirical study, Deutsche Bundesbank Monthly Report July 2002, http://217.110.182 .54/download/volkswirtschaft/mba/2002/200207_en_monetarypolicy.pdf (last viewed May 16th, 2007)

Deutscher Bundestag: Gesetzentwurf der Bundesregierung - Entwurf eines Gesetzes über die Erstreckung von gewerblichen Schutzrechten (Erstreckungsgesetz - ErstrG), Bundestags-Drucksache 12/1399 of October 30, 1991, pp. 1-74

Deutsches Institut für Normung: DIN-Norm für Methoden der Markenwertmessung geplant, Press release of January 19, 2005, www2.din.de/sixcms/detail.php? id=19108 (last viewed September 2, 2005)

Deutsches Patent- und Markenamt: Jahresbericht 2007, Munich 2008

Dickinson, Steve: Breaking News: China Changes Foreign Investment (FDI) Rules, http://www.chinalawblog.com/2007/11/breaking_news_china_changes_fo.ht $\mathrm{ml}$

(last viewed September 27, 2008)

Drees, Norbert: Markenbewertung und Markenberatung in Deutschland - Ergebnisse einer empirischen Studie, Erfurter Hefte zum angewandten Marketing, Heft 6, Erfurt 1999

Dürrfeld, Armin; Wingendorf, Petra: Lizenzierung von Markenrechten im Konzern, IStR 2005, p. 464 et seq.

Dvorak, Jenny: Der Lizenzvertrag im Franchising, Frankfurt am Main 2006

Ehrler, Jürgen: Ein DCF-Modell zur Markenbewertung, in: Baumann, Peter; Casanova, Marco (ed.), Ansätze zur Bildung eines Markenführungs- und bewertungsmodells. Reader zum Forschungsprojekt Corporate Brand Management, Berne 2003, pp. 73-84

Erlei, Mathias; Leschke, Martin; Sauerland, Dirk: Neue Institutionenökonomik, Stuttgart 1999

Ernst\&Young: 2005-2006 Global Transfer Pricing Surveys - Global Transfer Pricing Trends, Practices, and Analysis, November 2005, http://www.ey.com/g lobal/download.nsf/International/Transfer_Pricing_Global_Surveys_Q4_200 5/\$file/GlobalTPSurvey_Q4_2005.pdf (last viewed August 2, 2007)

Ernst\&Young: Business Restructuring - Three Taxation Issues, http://www.ey.c om/Global/assets.nsf/International/Tax_TrnsfrPrcng_Business_Restructurin g/\$file/EY_Tax_TrnfrPrcng_Restructuring.pdf (last viewed August 2, 2007)

Esch, Franz-Rudolf; Geus, Patrick: Ansätze zur Messung des Markenwerts, in: Esch, Franz-Rudolf (ed.): Moderne Markenführung. Grundlagen - Innovative Ansätze - Praktische Umsetzungen, 4th ed., Wiesbaden 2005, p. 1263 et seq.

Esch, Franz-Rudolf; Langner, Tobias; Rempel, Jan Eric: Ansätze zur Erfassung und Entwicklung der Markenidentität, in: Esch, Franz-Rudolf (ed.): Moderne Markenführung. Grundlagen - Innovative Ansätze - Praktische Umsetzungen, 4th ed., Wiesbaden 2005, p. 103 et seq. 
Esch, Franz-Rudolf; Wicke, Andreas; Rempel, Jan Eric: Herausforderungen und Aufgaben des Markenmanagements, in: Esch, Franz-Rudolf (ed.): Moderne Markenführung. Grundlagen - Innovative Ansätze - Praktische Umsetzungen, 4th ed., Wiesbaden 2005, p. 3 et seq.

Fabry, Bernd: Three-Dimensional Valuation of IP Rights, 3 Journal of Business Chemistry, iss. 3, p. 27 et seq. (2006)

Fammler, Michael: Der Markenlizenzvertrag, 2nd ed., Munich 2007

Farquhar, Peter H.: Managing Brand Equity, 30 Journal of Advertising Research, iss. 4, pp. RC-7-RC-12 (1990)

Farquhar, Peter H.; Han, Julia Y.; Ijiri, Yuri: Brands on the Balance Sheet, 1 Marketing Management, p. 16 et seq. (1992)

Fezer, Karl-Heinz: Entwicklungslinien und Prinzipien des Markenrechts in Europa - Auf dem Weg zur Marke als einem immaterialgüterrechtlichen Kommunikationszeichen, GRUR 2003, p. 457 et seq.

Fezer, Karl-Heinz: Markenrecht, Kommentar zum Markengesetz, zur Pariser Verbandsübereinkunft und zum Madrider Markenabkommen, 3rd ed., Munich 2001

Finkenzeller, Klaus: RFID-Handbuch, 4th ed., Munich 2006

Fischer, Oliver: Geliehener Ruhm, article on www.manager-magazin.de of August 13, 1999, http://www.manager-magazin.de/magazin/artikel/0,2828,32221, 00.html (last viewed November 6, 2008)

Flignor, Paul; Orozco, David: Intangible Asset \& Intellectual Property Valuation: A Multidisciplinary Perspective, http://www.wipo.int/sme/en/documents/ pdf/IP \_Valuation.pdf (last viewed October 17, 2006)

Flohr, Eckhard: Franchisevertrag, 3rd ed., Munich 2006

Förster, Thomas: Immaterielle Vermögenswerte nach IAS 38. Firmenwerte mit Zukunft und deren Behandlung nach IFRS, Saarbrücken 2006

Frahm, Lars-Gunnar: Markenbewertung. Ein empirischer Vergleich von Bewertungsmethoden und Markenwertindikatoren, Frankfurt am Main 2004

Franzen, Ottmar: ACNielsen Brand Performance System, in: Hanser, Peter; Högl, Siegfried; Maul, Karl-Heinz (ed.): Markenbewertung. Die Tank AG, Düsseldorf 2004, p. 129 et seq.

Franzen, Ottmar: Das Brand Performance System von ACNielsen: Standardisierte Markenbewertung auf der Grundlage von Marktforschungsdaten, in: Schimansky, Alexander (ed.), Der Wert der Marke, Munich 2004, p. 146 et seq.

Franzen, Ottmar: Markenbewertung, presentation slides, 2004, http://www.konz ept-und-markt.com/Docs/Markenwert_FH_Wiesbaden_Juni_2004.pdf

Franzen, Ottmar: Markenbewertung mit Hilfe von Ertragswertansätzen, DStR 1994, p. 1625 et seq.

Franzen, Ottmar; Fuchs, Michael; Paninka, Jörg: Psychologie der Marken, http:// www.konzept-und-markt.com/Docs/Cognitive \_Mapping.pdf (last viewed July 2nd, 2007)

Friedhoff, Isabelle: Marken in der Übernahmeabwehr, Düsseldorf 2006 
Gaiser, Brigitte: Brennpunkt Markenführung - Aufgabenbereiche und aktuelle Problemfelder der Markenführung, in: Gaiser, Brigitte; Linxweiler, Richard; Brucker, Vincent (ed.): Praxisorientierte Markenführung - Neue Strategien, innovative Instrumente und aktuelle Fallstudien, Wiesbaden 2005, p. 5 et seq.

Gebhardt, Karin; Stein, Matthias: Brand Status. Auf Kurs zum Markenerfolg: Marken und ihre Wettbewerber mit den Augen der Zielgruppe sehen. Ein Management-Instrument von icon brand navigation., slide presentation, $\mathrm{Nu}-$ remberg 2001

Geddes, H. Ross: An Introduction to Corporate Finance. Transactions and Techniques, 2nd ed., Chichester 2006

Gerpott, Torsten J.; Thomas, Sandra E.: Markenbewertungsverfahren, WiSt 2004, p. 394 et seq.

Gilmore, George William: Animism, Boston 1919

Goddar, Heinz: Deal-making, Understanding the Contractual Terms and Conditions for Licensing "out", WIPO Training Course paper, Singapore 2003

Göbel, Vanessa: Geschützte Marken, markenartikel 11/2008, p. 93 et seq.

Göttgens, Olaf; Sander, Björn; Wirtz, Bernd; Dunz, Markus: Markenbewertung als strategischer Erfolgsfaktur, Study by BBDO Consulting, http://www.bbdo .de/de/home/studien.download.Par.0011.Link1Download.File1Title.pdf (last viewed February 25, 2007)

Götting, Horst-Peter: Protection of Well-Known, Unregistered Marks in Europe and the United States, IIC 2000, p. 389 et seq.

Gold, Ivan: The Community Trade Mark Handbook, London 2001-2006

Grauel, Ralf: Die Pein der Weisen, brand eins 2/2003, p. 65 et seq.

Gream, Matthew: Trademark valuation: review in January 2004, http://matthewg ream.net/Professional/IntellectualProperty/review_trademark-valuation-012004.pdf (last viewed April 6, 2007)

Greenhalgh, Christine; Rogers, Mark: Trade Marks and Market Value in UK Firms, Working Paper No. 4/06, Intellectual Property Research Institute of Australia, Melbourne 2006

Greinert, Markus: Die bilanzielle Behandlung von Marken, Lohmar 2002

Greinert, Markus: Nutzungsdauer einer Marke im Konzernabschluss, BB 2004, p. 483 et seq.

Groppelli, Angelico A.; Nikbakht, Ehsan: Finance, Hauppauge 2000

Groß, Michael: Aktuelle Lizenzgebühren in Patentlizenz-, Know-How- und Computerprogrammlizenz-Verträgen: 2000/2001, WRP 2003, p. 1199 et seq.

Groß, Michael: Marken-Lizenzvertrag, Heidelberger Musterverträge, Heft 84 4th ed., Frankfurt am Main 2008

Großfeld, Bernhard: Unternehmens- und Anteilsbewertung im Gesellschaftsrecht, 4th ed., Cologne 2002

Grüner, Tanja: Behandlung der immateriellen Vermögenswerte im Rahmen der Erstkonsolidierung nach IAS/IFRS, Munich 2006

Günther, Thomas; Kriegbaum-Kling, Catharina: Brand Valuation and Control: an Empirical Study, Schmalenbach Business Review 2001, p. 263 et seq. 
Häusler, Jürgen; Stucky, Nik: Markenmanagement und finanzielle Transaktionen, in: Wiedmann, Klaus-Peter; Heckemüller, Carsten (ed.): Ganzheitliches Corporate Finance Management - Konzept, Anwendungsfelder, Praxisbeispiele, Wiesbaden 2003

Haigh, David: Brand valuation: what it means and why it matters, in: Brands in the Boardroom, IAM supplement No. 1, pp. 18-22 (2004)

Hand, John; Lev, Baruch: Introduction and Overview, in: Hand, John; Lev, Baruch (ed.): Intangible Assets. Values, Measures, and Risks, p. 1 et seq., Oxford University Press, Oxford 2003

Hand, John; Lev, Baruch (ed.): Intangible Assets. Values, Measures, and Risks, Oxford University Press, Oxford 2003

Hanser, Peter; Högl, Siegfried; Maul, Karl-Heinz (ed.): Markenbewertung. Die Tank AG, Düsseldorf 2004

Harhoff, Dietmar; Scherer, Frederic M.; Vopel, Katrin: Exploring the tail of patented invention value distributions, in: Granstrand, Ove (ed.): Economics, Law and Intellectual Property: Seeking strategies for research and teaching in a developing field, Boston/Dordrecht/London 2003, p. 279 et seq.

Harrison, Suzanne; Sullivan, Patrick H.: Profiting from intellectual capital: learning from leading companies, 32 Industrial and Commercial Training, iss. 4, p. 139 et seq. (2000)

Harte-Bavendamm, Henning: Einleitende Anmerkungen zum Aufsatz "Markentechnische Beobachtungen zum Markenschutz" von Prof. Dr. Alexander Deichsel, GRUR 1998, p. 335 et seq.

Harte-Bavendamm, Henning; von Bomhard, Verena: Abgrenzungsvereinbarungen und Gemeinschaftsmarken, GRUR 1998, p. 530 et seq.

Hasselblatt, Gordian N. (ed.): Münchener Anwaltshandbuch Gewerblicher Rechtsschutz, 3rd ed., Munich 2009

Havenstein, Moritz; Heiden, Matthias: Markenwertmessung im betrieblichen Rechnungswesen - Entscheidungshilfe oder Sorgenkind?, BB 2003, p. 1272 et seq.

Henning-Bodewig, Frauke; Kur, Annette: Marke und Verbraucher: Funktionen der Marke in der Marktwirtschaft. Band I. Grundlagen, Weinheim 1988

Herve, Yves; Stock, Oliver; Bodenstein, Roland: Dokumentation der Angemessenheit von Verrechnungspreisen in der Praxis - Teil IV: Lizenzgebühren, BC 2005, p. 268 et seq.

Hildebrandt, Ulrich: Marken und andere Kennzeichen, Cologne/ Berlin/ Munich 2006

Hillery, John S.: Securitization of Intellectual Property: Recent Trends from the United States, http://www.iip.or.jp/summary/pdf/WCORE2004s.pdf (last viewed May 8, 2006)

Hirt, Rainer: Audio-Branding: Klingel-Fluch oder Markensegen?, http://www.ma rkenlexikon.com/d \_texte/hirt \_klingelfluch \_markensegen.pdf

(last viewed January 12, 2008)

Homburg, Christian; Krohmer, Harley: Grundlagen des Marketingmanagements, Einführung in Strategie, Instrumente, Umsetzung und Unternehmensführung, Wiesbaden 2006 
Hüttche, Tobias; von Brandis, Henning: Lexikon Rechnungslegung Bilanzanalyse Bilanzpolitik, Stuttgart 2003

Hughes, Karen; Borzumato, Domenico: Tax tips for IP owners, 17 Managing Intellectual Property, iss. 8, pp. 35-37 (September 2006)

Ingerl, Reinhardt: Die Gemeinschaftsmarke, Munich 1996

Ingerl, Reinhard; Rohnke, Christian: Markengesetz, 2nd ed., Munich 2003

Institut der Wirtschaftsprüfer (IDW): Entwurf IDW Standard: Grundsätze zur Bewertung immaterieller Vermögenswerte (IDW ES 5), http://www.idw.de/i $\mathrm{dw} /$ download/IDW $\backslash 20 \mathrm{ES} \backslash \_205$.pdf?id=413472 $\backslash \&$ property=Inhalt $\quad$ (last viewed February 5, 2007)

Interbrand/BusinessWeek: Best Global Brands 2006. A Ranking by Brand Value, company brochure, http://www.ourfishbowl.com/images/surveys/BGB06Re port $\backslash$ 072706.pdf (last viewed March 28, 2007)

Interbrand Zintzmeyer \& Lux: Brand Valuation. The Key to unlock the Benefits from your Brand Assets., company brochure (undated)

Interbrand Zintzmeyer \& Lux: Wert haben und Wert sein. Die Markenbewertung von Interbrand., company brochure, 2005

International Valuation Standards Committee (IVSC): International Valuation Standards, 7th ed., London 2005

IPR Helpdesk: Trade Mark Agents Manual, http://www.ipr-helpdesk.org/docum entos/docsPublicacion/pdf_xml/8_ActionLineTrademarksManual[00000035 46_00].pdf (last viewed June 19, 2006)

Irmscher, Markus: Markenwertmanagement. Aufbau und Erhalt von Markenwissen und -vertrauen im Wettbewerb. Eine informationsökonomische Analyse, Frankfurt am Main 1997

Jaeger-Lenz, Andrea; Freiwald, Sven: Die Bedeutung der Erweiterung des Madrider Markensystems für die markenrechtliche Praxis, GRUR 2005, p. 118 et seq.

Jansen, Michel: Brand Prototyping: Developing meaningful brands, http://www. brandchannel.com/papers \_review.asp?sp \_id=1291 (last viewed July 3rd, 2007)

Jenner, Thomas: Flexibilität und Markenwert, Das Wirtschaftsstudium 2000, p. 945 et seq.

Kalmbacher, Thomas; Repenn, Wolfgang: Monetäre Bewertung von Marken. Anlässe und Methoden, presentation, http://www.patente-stuttgart.de/vortr aege/tgs06_kalmbacher_repenn.pdf (last viewed March 25, 2007)

Kamp, Andreas; Ricke, Markus: Stichwort: Informationsasymmetrie, BKR 2003, p. 527 et seq.

Kane, Siegrun D.: Trademark Law - A Practitioner's Guide, 4th ed., New York 2004

Kapferer, Jean-Noel: The new strategic brand management: creating and sustaining brand equity long term, 3rd ed., London/Sterling 2004

Katz, Michael L.; Shapiro, Carl: Network externalities, competition, and compatibility, 75 Am.Econ.Rev., iss. 3, p. 424 et seq. (1985) 
Kaufmann, Gwen; Sattler, Henrik; Völckner, Franziska: Markenstrategische Optionen, Research Papers on Marketing and Retailing, University of Hamburg, no. 29, Hamburg 2005

Keller, Kevin Lane: Conceptualizing, Measuring, and Managing Customer-Based Brand Equity, 57 Journal of Marketing, issue 1, p. 1 et seq. (1993)

Kern, Wolfgang: Bewertung von Warenzeichen, Betriebswirtschaftliche Forschung und Praxis 1962, p. 17 et seq.

King, Alfred M.: Valuation: what assets are really worth, New York 2002

Klawitter, Christian; Hombrecher, Lars: Gewerbliche Schutzrechte und Urheberrechte als Kreditsicherheiten, WM 2004, p. 1213 et seq.

Kotler, Philip: Marketing management: analysis, planning, and control, 5th ed., Englewood Cliffs, NJ, 1984

Kranz, Marcel: Markenbewertung - Bestandsaufnahme und kritische Würdigung, in: Meffert, Heribert; Burmann, Christoph; Koers, Martin (ed.): Markenmanagement, Wiesbaden 2002, p. 429 et seq.

Kraßer, Rudolf: Schadensersatz für Verletzungen von gewerblichen Schutzrechten und Urheberrechten nach deutschem Recht, GRUR Int. 1980, p. 259 et seq.

Kudraß, Raymond; Schäfer, Gabriele: Rating in der Bankenpraxis - Worauf Unternehmen achten sollten, BC 2003, p. 35 et seq.

Künzel, Manuela: Die Marke und ihr Wert, Saarbrücken 2006

Kur, Annette: TRIPs und das Markenrecht, GRUR 1994, p. 987 et seq.

Kur, Annette: Was macht ein Zeichen zur Marke?, MarkenR 2000, p. 1 et seq.

Lackert, Clark W.; Perry, Maren C.: Protecting well-known and famous marks: a global perspective, Building and enforcing intellectual property value 2008, p. 63 et seq., http://www.buildingipvalue.com/08_global/60-62Stockmair. pdf (last viewed February 4, 2008)

Lange, Paul: Marken- und Kennzeichenrecht, Munich 2006

Lanjouw, Jean O.: Patent Protection in the Shadow of Infringement: Simulation Estimations of Patent Value, 65 The Review of Economic Studies, p. 671 et seq. (1998)

Leitherer, Eugen: Die Entwicklung der modernen Markenformen, Markenartikel 1955 , p. 539 et seq.

Lev, Baruch: Intangibles - Management, Measurement, and Reporting, Washington, D.C. 2001

Liberman, Adam: IP issues in mergers and acquisitions, presentation of October 14, 2003, http://www.wipo.int/sme/en/activities/meetings/singapore \_03/ singapore $\backslash$ _liberman $\backslash \_10$.pdf (last viewed February 4, 2008)

Limpert, Brad; Samiian, Ali: Conducting an Intellectual Property Audit and IP Due Diligence, Intellectual Property Summit 2002, Infonex conference paper, http://www.gowlings.com/resources/PublicationPDFs/ConductingIPAudit andIPDueDiligence_Reformatted.pdf (last viewed July 23, 2007)

Loschelder, Michael: Der Schutz technischer Entwicklungen und praktischer Gestaltungen durch das Marken- und das Lauterkeitsrecht - Versuch einer Bewertung der Rechtsprechung der letzten zwei Jahre, GRUR Int. 2004, p. 767 et seq. 
Mahmud, Shahnaz: Securitizing for the future, 17 Managing Intellectual Property, iss. 8, pp. 22-24 (September 2006)

Manning-Schaffel, Vivian: Branding that Makes Scents, article of August 14, 2006 on brandchannel.com,

http://www.brandchannel.com/start1.asp?fa \_id=327 (last viewed January 14, 2008)

Manton, Steve: Integrated intellectual asset management: a guide to exploiting and protecting your organization's intellectual assets, Aldershot 2006

Marx, Claudius: Deutsches, europäisches und internationales Markenrecht, 2nd ed., Cologne 2007

Mayer, Hans-Jochem; Kroiß, Ludwig (ed.): Rechtsanwaltsvergütungsgesetz, Handkommentar, 2nd ed., Baden-Baden 2006

Meckl, Reinhard: Übung: Funktionsbezogenes Internationales Management (IM) SBWL IM III - 'Funktionsfelder', presentation slides, Bayreuth 2005

Medansky, Keith W.; Dalinka, Alan S.: Considering intellectual property securitisation, http://www.buildingipvalue.com/05\_NA/143\_146.htm (last viewed May 14, 2007)

Meffert, Heribert; Burmann, Christoph: Wandel in der Markenführung - vom instrumentellen zum identitätsorientierten Markenverständnis, in: Meffert, Heribert; Burmann, Christoph; Koers, Martin (ed.): Markenmanagement. Identitätsorientierte Markenführung und praktische Umsetzung, 2nd ed., Wiesbaden 2005, p. 19 et seq.

Menninger, Jutta; Kunowski, Stefan: Wertermittlung von Patenten, Technologien und Lizenzen vor dem Hintergrund von Optimierungsstrategien, DStR 2003, p. 1180 et seq.

Meissner, Sabine: Markenbewertung bei Mergers \& Acquisitions. Analyse und Konzeption am Beispiel der Pharmaindustrie, Wiesbaden 2003

Meissner, Sabine: Markenbewertung - Wie ist eine Marke bei Übernahmen und Fusionen zu bewerten?, Science Factory 2004, p. 1 et seq.

Mellerowicz, Konrad: Markenartikel - Die ökonomischen Gesetze ihrer Preisbildung und Preisbindung, 2nd ed., Munich/Berlin 1963

Merriam-Webster Online Dictionary: http://www.m-w.com/ (last viewed October 25, 2006)

Michaels, Amanda: A Practical Guide to Trade Mark Law, 3rd ed., London 2002

Michalewicz, Zbigniew; Fogel, David B.: How to Solve It: Modern Heuristics, 2nd ed., Berlin 2004

Morcom, Christopher; Roughton, Ashley; Graham, James: The Modern Law of Trade Marks, London 1999

MP Marketing Partner AG: Studie: Rentabilität von Marken oft fraglich - Unternehmen im Zugzwang, press release of August 4, 2006, http://www.marketin gpartner.de/index.php?id=23\&tx_mininews_pi1[showUid] $=131 \&$ cHash $=4 \mathrm{e} 3$ 60e7ba2 (last viewed October 4, 2006)

Murphy, John M.: Brand Strategy, Cambridge 1990

Nabrotzki, Stefanie: Lizenzen an Immaterialgüterrechten als Mittel der Kapitalaufbringung, Cologne 2008 
Nestler, Anke: Bewertung von Intellectual Property bei konzerninternen Übertragungen bzw. Nutzungsüberlassung, presentation slides of May 19, 2006

Nordemann, Axel: Wettbewerbsrecht Markenrecht, 10th ed., Baden-Baden 2004

Office for Harmonization in the Internal Market (Trade Marks and Designs) (OHIM): Guidelines Concerning Proceedings before the Office for Harmonization in the Internal Market (Trade Marks and Designs) - Part B, Examination Draft, DIPP Status: 2006, http://oami.europa.eu/en/mark/marque/pdf/Ex amination24_7_2006.pdf (last viewed January 4, 2008)

Office for Harmonization in the Internal Market (Trade Marks and Designs) (OHIM): Statistics of Community Trade Marks 2007, http://oami.europa.eu/pdf/offic e/SSC009-Statistics_of_Community_Trade_Marks_2007.pdf (last viewed September 7, 2008)

Office for Harmonization in the Internal Market (Trade Marks and Designs) (OHIM): Tarzans berühmter Schrei, Press release CP/07/01 of November 5, 2007, ht tp://oami.europa.eu/de/office/press/pdf/051107DE.pdf (last viewed September 23, 2008)

Organisation for Economic Co-operation and Development (OECD): Transfer Pricing Guidelines for Multinational Enterprises and Tax Administrations, Paris 2001

Orth, Stephan: Wie riecht ein Zimmermädchen im Hilton?, http://www.spiegel.de /reise/fernweh/0,1518,471207,00.html (last viewed January 14, 2008)

Pakes, Ariel: Patents as options: some estimates of the value of holding European patent stocks, 54 Econometrica iss. 4, p. 755 et seq. (1986)

Paschke, Dennis: Grundlagen der Volkswirtschaftslehre, 4th ed., Heidenau 2004

Perrey, Jesko; Riesenbeck, Hajo: Was Marken wirklich wert sind, akzente 2004, p. 2 et seq.

Phillips, Jeremy: Trade Mark Law: A Practical Anatomy, Oxford 2003

Pitkethly, Robert: The valuation of patents: A review of patent valuation methods with consideration of option based methods and the potential for further research, Judge Institute Working Paper WP 21/97, Cambridge 1997

Platon: Apology of Socrates

PricewaterhouseCoopers: Shedding light on IFRS: International Financial Reporting Standard 3 - The new Business Combinations standard, http://www.pw c.com/Extweb/service.nsf/docid/E2A4A0E07DBC26E480256CC40039AD3 D/\$file/Sheddinglight8pg.pdf (last viewed August 1, 2007)

PricewaterhouseCoopers; GfK Marktforschung; Sattler, Henrik; Markenverband e.V. (ed.): Praxis von Markenbewertung und Markenmanagement in deutschen Unternehmen, Neue Befragung 2005, 3rd ed., Frankfurt/Main, 2006

Progoff, Susan; Palladino, Vincent N.: Tips for successful trademark licensing, in: Licensing in the Boardroom 2005. Key licensing issues for senior executives. A supplement to Intellectual Asset Management magazine, London 2005, p. 1 et seq.

Razgaitis, Richard: Valuation and Pricing of Technology-Based Intellectual Property, Hoboken, 2003 
Reese, Jan Frederik: Die Bewertung von Immaterialgüterrechten, Göttingen 2005

Reiche, Klaus: Instrumente zur Verminderung der Informationsasymmetrie beim Unternehmenskauf, DStR 2000, p. 2056 et seq.

Repenn, Wolfgang; Weidenhiller, Gabriele: Markenbewertung und Markenverwertung, 2nd ed., Munich 2005

Rugman, John; Hadjiloucas, Tony: Valuing IP and determining the cost of capital, Special Focus Chapter, PricewaterhouseCoopers 2005, www.pwc.com/gx/e ng/ins-sol/publ/ipvalue/Valuing-IP-Cost-capital-05.pdf

Saigol, Lina: Lights go down on the acquisition party, Financial Times article published August 22, 2007 on ft.com, http://www.ft.com/cms/s/0/f632e45a-5 014-11dc-a6b0-0000779fd2ac.html (last viewed August 22, 2007)

Sambuc, Thomas: Was soll das Markenrecht?, WRP 2000, p. 985 et seq.

Sander, Björn; Jakobs, Andreas: Markenmanagement ist Wertmanagement, marketingjournal 2004, p. 34 et seq.

Sattler, Henrik: Markenbewertung, ZfB 1995, p. 663 et seq.

Sattler, Henrik: Markenbewertung: State of the Art, Research Papers on Marketing and Retailing, University of Hamburg, No. 27, Hamburg 2005

Sattler, Henrik: Wovon hängt der langfristige Wert von Marken ab?, Ergebnisse einer Markenexperten-Befragung in Zusammenarbeit mit der GfK und dem Markenverband, http://www.henriksattler.de/publikationen/HS \_048. pdf (last viewed February 9, 2007)

Sattler, Henrik; Högl, Siegfried; Hupp, Oliver: Evaluation of the financial value of brands, Research Papers on Marketing and Retailing, University of Hamburg, No. 7, Hamburg 2002

Schankerman, Mark; Pakes, Ariel: Estimates of the Value of Patent Rights in European Countries during the Post-1950 Period, 96 Econ. J., p. 1052 et seq. (December 1986)

Schaub, Renate: Schadensersatz und Gewinnabschöpfung im Lauterkeits- und Immaterialgüterrecht, GRUR 2005, p. 918 et seq.

Scherer, Frederic M.; Harhoff, Dietmar; Kukies, Jörg: Uncertainty and the Size Distribution of Rewards from Technological Innovation, 10 Journal of Evolutionary Economics, p. 175 et seq. (2000)

Schimansky, Alexander (ed.): Der Wert der Marke, Munich 2004

Schimansky, Alexander: Markenbewertungsverfahren aus Sicht der Marketingpraxis, in: Schimansky, Alexander (ed.), Der Wert der Marke, Munich 2004, p. 12 et seq.

Schimansky, Alexander: Schlechte Noten für Markenbewerter, marketingjournal 2003, p. 44 et seq.

Schmeisser, Wilhelm; Leonhardt, Maik: Asset-Backed Securities - Forderungsverbriefung für den gehobenen Mittelstand als Finanzierungsalternative, DStR 2007, p. 169 et seq.

Schmeisser, Wilhelm; Schmeisser, Karin: Auswirkungen von Basel II für den Mittelstand: Kreditvergabe und Bepreisung von Krediten, DStR 2005, p. 344 et seq. 
Schmidbauer, Rainer: Immaterielle Vermögenswerte in der Unternehmensrechnung: Abbildung im Jahresabschluss und Ansätze zur Steuerung, DStR 34, p. 1442 et seq.

Schütte, Jens: Aktivierungskonzepte immaterieller Vermögenswerte, Hamburg 2006

Schunk, Holger; Lütje, Dierk; Heil, Oliver P.: Nur was man messen kann, kann man auch managen, markenartikel 2004, p. 24 et seq.

Shapiro, Carl; Varian, Hal R.: Information Rules. A Strategic Guide to the Network Economy, Boston 1999

Silbiger, Steven: The 10-day MBA, 3rd ed., London 2005

Simensky, Melvin: The new role of intellectual property in commercial transactions. Recent trends in the valuation, exploitation and protection of intellectual property, New York 1994

Simon, Carol J.; Sullivan, Mary W.: The Measurement and Determinants of Brand Equity: A Financial Approach, 12 Marketing Science, iss. 1, p. 28 et seq. (winter 1993)

Simpson, Margaret J.: Valuation of Scandinavian patent rights across industries, nationalities, and time: analysis, estimates, and applications, Ann Arbor 1992

Sine autore: Markenbewertung und Markenberatung in Deutschland, absatzwirtschaft 1999, p. 96 et seq.

Sine autore: Markenrechtskrimi um die 60-Millionen-Euro Marke "3..2..1..meins!", MarkenNews of June 29, 2005, http://www.markenbusiness.com/de/news.p hp? newsid=2113 (last viewed October 3, 2008)

Sine autore: Marktverwirrung um “3..2..1..meins!"?, MarkenThema of March 15, 2007, http://www.markenbusiness.com/de/news.php?newsid=4904 (last viewed October 3, 2008)

Sine autore (Ocean Tomo): Ocean Tomo releases results of world's first ever live patent auction, press release of May 11, 2006, http://www.oceantomo.com/ press/Post-Post-Auction \_5.11.06.pdf (last viewed February 27, 2008)

Sine autore (The Economist): Securitising Intellectual Property: Intangible Opportunities, http://w4.stern.nyu.edu/news/news.cfm?doc $\backslash$ id $=6129$ (last viewed August 6, 2007)

Smith, Gordon V.: Trademark Valuation, New York 1997

Smith, Gordon V.; Parr, Russell L.: Valuation of intellectual property and intangible assets, New York 1989

Spannagl, Johannes: Neuer Standard in der Markenbewertung, markenartikel 2001, p. 38 et seq.

Spannagl, Johannes; Biesalski, Alexander: Brand Rating-Modell, in: Hanser, Peter; Högl, Siegfried; Maul, Karl-Heinz (ed.): Markenbewertung. Die Tank AG, Düsseldorf 2004, p. 81 et seq.

Srivastava, Rajendra K.; Shervani, Tasadduq A.; Fahey, Liam: Market-Based Assets and Shareholder Value: A Framework for Analysis, 62 Journal of Marketing, iss. 1, p. 2 et seq. (January 1998)

Steinbeck, Anja: Die Verwertbarkeit der Firma und der Marke in der Insolvenz, NZG 1999, p. 133 et seq. 
Strebinger, Andreas: Der Dschungel der Markenbewertung, Markenartikel 2005, p. 37 et seq.

Ströbele, Paul; Hacker, Franz: Markengesetz, 8th ed., Cologne 2006

Stucky, Nik: Interbrand-Modell, in: Hanser, Peter; Högl, Siegfried; Maul, KarlHeinz (ed.): Markenbewertung. Die Tank AG, Düsseldorf 2004, p. 103 et seq.

Stucky, Nik: Monetäre Markenbewertung nach dem Interbrand-Ansatz, in: Schimansky, Alexander (ed.): Der Wert der Marke, Munich 2004, p. 432 et seq.

Tauber, Edward M.: Brand Leverage: Strategy for Growth in a Cost-Control World, 16 Journal of Advertising Research, iss. 4, p. 26 et seq. (1988)

Toh, Min Joo Benjamin: Fuel Cell Controller, Department of Electrical and Computer Engineering, Curtin University of Technology, Perth 2004

Toubassy, Ramez: Brand Licensing. A misunderstood piece of the marketing mix, White paper, http://www.brandchannel.com/images/papers/374_White Paper-BrandSensePartners.pdf (last viewed July 23, 2007)

Vanzetti, Adriano: Funktion und Rechtsnatur der Marke - 1. Teil, GRUR Ausl. 1965, p. 128 et seq.

Völckner, Franziska; Pirchegger, Barbara: Immaterielle Werte in der internen und externen Rechnungslegung deutscher Unternehmen - Eine empirische Bestandsaufnahme, Research Papers on Marketing and Retailing, University of Hamburg, No. 28, Hamburg 2005

Volkenner, Thomas; Walter, Karl-Friedrich: Die Endfassung der Neuen Baseler Eigenkapitalvereinbarung (Basel II), DStR 2004, p. 1399 et seq.

von Bomhard, Verena: Where do you have to be well known to be well known?, Lovells Intellectual Property Newsletter January 2008, p. 12

von Graevenitz, Georg: Which Reputations Does a Brand Owner Need? Evidence from Trade Mark Opposition, GESY Discussion Paper No. 215, Munich 2007, http://www.gesy.uni-mannheim.de/dipa/215.pdf (last viewed January $28,2008)$

Weber, Jürgen; Stoffels, Mario; Kleindienst, Ingo: Internationale Verrechnungspreise im Konzern, Vallendar 2004

Werwigk, Claudius: Kapitalaufbringung durch Immaterialgüterrechte, LES-Schriftenreihe zum Technologietransfer, vol. 3, Baden-Baden 2006

Wirtz, Bernd W; Göttgens, Olaf; Dunz, Markus: Ansätze zur Markenbewertung, der markt 2001, p. 159 et seq.

Woodward, Caroline: Valuation of intellectual property, PricewaterhouseCoopers brochure, www.pwc.com/gx/eng/ins-sol/publ/ipvalue/pwc_1.pdf (last viewed September 12, 2005)

World Intellectual Property Organization (WIPO): Guide to the International Registration of Marks under the Madrid Agreement and the Madrid Protocol, WIPO Publication No. 455(E), Geneva 2008

World Intellectual Property Organization (WIPO): Record Number of International Trademark Filings in 2007, press release, http://www.wipo.int/press room/en/articles/2008/article_0007.html (last viewed April 3, 2008) 
World Intellectual Property Organization (WIPO): WIPO Magazine No. 3, June 2006, http://www.wipo.int/edocs/pubdocs/en/2006/wipo_pub_121_2006_3. pdf (last viewed August 25, 2006)

Wurzer, Alexander J.; Reinhardt, Dieter F.: Bewertung technischer Schutzrechte. Praxis der Patentbewertung, Cologne 2006

Zednik, Anita; Strebinger, Andreas: Marken-Modelle in der Praxis. Darstellung, Analyse und kritische Würdigung, Wiesbaden 2005

Zimmermann, Rainer; Klein-Bölting, Udo; Sander, Björn; Murad-Aga, Tharek: Brand Equity Excellence, Volume 1: Brand Equity Review, BBDO 2001, ht tp://www.bbdo.de/de/home/studien.download.Par.0009.Link1Download.Fi le1Title.pdf (last viewed March 8, 2005) 
